\title{
Explanatory Notes for the Energy-Resources Map of the Circum-Pacific Region, Pacific Basin Sheet
}

By KENNETH J. DRUMMOND, TOMOAKI SUMII, KOJI WAKITA, OSAMU MATSUBAYASHI, KEIZO FUJII, TOMOYUKI MORITANI, W. DAVID PALFREYMAN, MARCELO R. YRIGOYEN, and JOSE CORVALAN D.

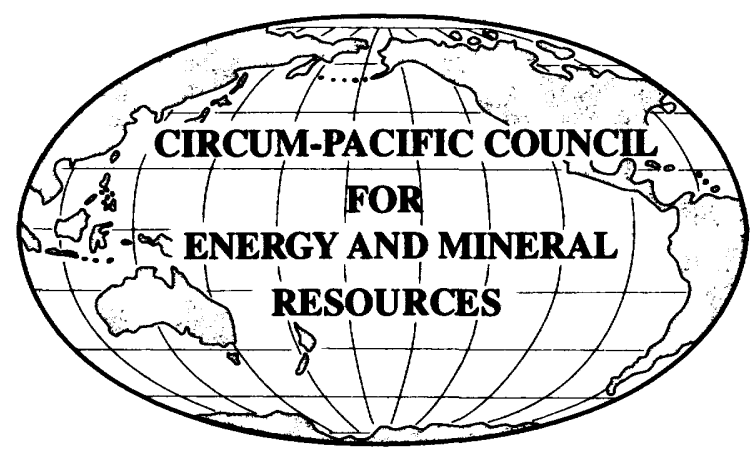




\section{EXPLANATORY NOTES FOR THE ENERGY-RESOURCES MAP OF THE CIRCUM-PACIFIC REGION PACIFIC BASIN SHEET}

Scale: 1:17,000,000

By

Kenneth J. Drummond, National Energy Board, Calgary, Alberta

Tomoaki Sumii, Koji Wakita, Osamu Matsubayashi, Keizo Fujii, and

Tomoyuki Moritahi, Geological Survey of Japan, Ibaraki, Japan

W. David Palfreyman, Australian Geological Survey Organisation, Canberra, Australia

Marcelo R. Yrigoyen, Trend Argentina, S.A., Buenos Aires, Argentina

José Corvalán D., Servicio Nacional de Geologia y Mineria, Santiago, Chile 


\section{Explanatory Notes to Supplement the \\ ENERGY RESOURCES MAP \\ OF THE CIRCUM-PACIFIC REGION \\ PACIFIC BASIN SHEET}

\section{PETROLEUM RESOURCES}

Kenneth J. Drummond, National Energy Board, Calgary, Alberta, Canada

Marcelo R. Yrigoyen, Trend Argentina S.A., Buenos Aires, Argentina

Guillermo P. Salas, Consijo de Recursos Minerales, Mexico, D.F.7 Mexico

Tomoaki Sumii, and Hiro'o Natori, Geological Survey of Japan, Tsukuba 305, Japan

Masakazu Kato, Japan National Oil Corporation, Tokyo 100, Japan

W. David Palfreyman, Australian Geological Survey Organisation, Canberra, Australia

\section{COAL DEPOSITS}

Keizo Fujii, Eiji Inoue, and Masatoshi Sogabe, Geological Survey of Japan, Tsukuba 305, Japan

Marcelo R. Yrigoyen, Trend Argentina S.A., Buenos Aires, Argentina

W. David Palfreyman, Australian Geological Survey Organisation, Canberra. Australia

Gordon H. Wood and William V. Bour, III, U.S. Geological Survey, Reston, Virginia 22092,U.S.A.

Paul W. Richards, Valley Center, California 92082, U.S.A.

\section{GEOTHERMAL RESOURCES}

Marcelo R. Yrigoyen, Trend Argentina S.A., Buenos Aires, Argentina

Theresa R. Swint-Iki, U.S. Geological Survey, Menlo Park, California U.S.A.

Osamu Matsubayashi, Geological Survey of Japan, Tsukuba 305, Japan

W. David Palfreyman, Australian Geological Survey Organisation, Canberra. Australia

\section{GEOLOGIC BACKGROUND}

Kenneth J. Drummond, National Energy Board, Calgary, Alberta, Canada José Corvalán D., Servicio Nacional de Geologia y Mineria, Santiago, Chile

Marcelo R. Yrigoyen, Trend Argentina S.A., Buenos Aires, Argentina

Koji Wakita and Tomoaki Sumii, Geological Survey of Japan, Tsukuba 305, Japan

H. Frederick Doutch and W. David Palfreyman, Australian Geological Survey Organisation, Canberra, Australia

Map compilation coordinated by

George Gryc, Circum-Pacific Map Project General Chairman,

U.S. Geological Survey, Menlo Park, California 94025, U.S.A 
Introduction 1

\section{CONTENTS}

Circum-Pacific Map Project 1

Energy-Resources Map of the Pacific Basin Sheet 1

Background Information 2

Land Areas 2

Ocean areas 4

Geologic setting 4

Tectonic setting $\mathbf{5}$

Energy resources 7

Oil and natural gas 7

Sedimentary basins of Northeast Quadrant 7

Offshore Pacific Coast of the United States 9

Onshore Southern California basins $\mathbf{1 0}$

Middle America Marginal-Trough Basin 10

Oil sand 14

Oil shale 14

Coal 15

Geothermal resources 17

References cited and additional sources of data (from Explanatory Notes accompanying Quadrant Maps) 21

Northeast Quadrant 21

Southeast Quadrant 24

Northwest Quadrant 27

Southwest Quadrant 34

Additional Sources of Data 34

Figures 1-24 37-64

Tables 1-20 65-106

Appendix I. Conversion factors 107

Appendix II. List of abbreviations used 107

Appendix III. Glossary 107

Appendix IV. Summarized A.S.T.M. classification of coals by rank 109 


\section{INTRODUCTION}

\section{CIRCUM-PACIFIC MAP PROJECT}

The Circum-Pacific Map Project (CPMP) is a cooperative international effort designed to show the relationship of known energy and mineral resources to the major geologic features of the Pacific basin and surrounding continental areas. Available geologic, mineral, and energy-resource data are being complemented by new, project-developed data sets such as magnetic lineations, seafloor mineral deposits, and seafloor sediment. Earth scientists representing some 180 organizations from more than 40 Pacific-region countries are involved in this work.

Six overlapping equal-area regional maps at a scale of $1: 10,000,000$ form the cartographic base for the project: the four Circum-Pacific Quadrants (Northwest, Southwest, Southeast, and Northeast), and the Antarctic and Arctic Sheets. There is also a Pacific Basin Sheet at a scale of 1:17,000,000. The published map series include the Base Map Series and the Geographic Series (published from 1977 to 1990), the Plate-Tectonic Series (published from 1981 to 1992), the Geodynamic Series (published from 1984 to 1990), and the Geologic Series (published from 1984 to 2000); all include six map sheets. The thematic map series in the process of completing publication include MineralResources and Energy-Resources Maps. Altogether, 60 map sheets are planned.

The maps are prepared cooperatively by the CircumPacific Council for Energy and Mineral Resources and the U.S. Geological Survey and are available from USGS, Information Services, Box 25286, Federal Center, Denver, Colorado 80225, U.S.A. Maps published prior to mid1990 are available from Dr. H. Gary Greene, CircumPacific Council for Energy and Mineral Resources, Moss Landing Marine Laboratory, MLML, Box 450, Moss Landing, California 95039-0450, U.S.A

The Circum-Pacific Map Project is organized under six panels of geoscientists representing national earthscience organizations, universities, and natural-resource companies. The six panels correspond to the basic map areas. Current panel chairs are Kenneth J. Drummond (Northeast Quadrant), Tomoyuki Moritani (Northwest Quadrant), George W. Moore (Arctic Region), Ian W.D. Dalziel (Antarctic Region), vacant (Southwest Quadrant), vacant, (Southeast Quadrant). José Corvalán D., chaired the Southeast Quadrant Panel from its inception in 1974 to his death in 1996; the Panel completed compilations of all eight topical maps of that quadrant.

Project coordination and final cartography are being carried out by the U.S. Geological Survey, under the direction of Circum-Pacific Map Project General Chairman George Gryc of Menlo Park, California. Project headquarters are located at 345 Middlefield Road, MS
951, Menlo Park, California 94025, U.S.A. The project has been overseen from its inception by John A. Reinemund, Director of the project since 1982.

The framework for the Circum-Pacific Map Project was developed in 1973 by a specially convened group of 12 North American geoscientists meeting in California. The project was officially launched at the First CircumPacific Conference on Energy and Mineral Resources, which met in Honolulu, Hawaii, in August 1974. Sponsors of the conference were the American Association of Petroleum Geologists (AAPG), Pacific Science Association (PSA), and the Coordinating Committee for Offshore Prospecting for Mineral Resources in Offshore Asian Areas (CCOP). The Circum-Pacific Map Project operates as an activity of the Circum-Pacific Council for Energy and Mineral Resources, a nonprofit organization that promotes cooperation among Circum-Pacific countries in the study of energy and mineral resources of the $\mathrm{Pa}$ cific basin. Founded by Michel T. Halbouty in 1972, the Council also sponsors quadrennial conferences, topical symposia, scientific training seminars, and the Earth Science Series of publications.

\section{ENERGY-RESOURCES MAP OF THE PACIFIC BASIN SHEET}

The Energy-Resources Map of the Circum-Pacific Region, Basin Sheet is a compilation at a scale of $1: 17,000,000$ of a series of four overlapping $1: 10,000,000$ scale map sheets. The maps in the 1:10,000,000 series includes the Northeast Quadrant, Southeast Quadrant, Northwest Quadrant, and the Southwest Quadrant, and an Arctic Sheet.

Information depicted on the Energy-Resources Map of the Circum-Pacific Region, Basin Sheet includes a generalized geologic background, oil and gas fields, oil sands, oil shale, coal deposits, geothermal energy sites, hot springs, onshore basin isopachs, and sediment isopachs in ocean areas.

The geologic background for the Energy-Resources Map shows the relevance of the "economic basement" to the sedimentary basin areas. Depicted in a generalized format are Precambrian basement, igneous intrusives, volcanic cover, and deformed sedimentary fold belts. Bathymetry and sediment isopachs comprise the background for the oceanic areas.

Active plate boundaries shown in red are taken from the Plate-Tectonic Map of the Circum-Pacific Region (Moore, 1981). Spreading axes are depicted as lines of uniform width $(1 \mathrm{~mm})$ rather than by lines of varying width to represent spreading rates as is done on the PlateTectonic Maps.

The purpose of this report is to supplement the Energy-Resources Map of the Circum-Pacific Region, Ba- 
sin Sheet with additional data, explanations, and references that could not be depicted on the face of the map. The notes for the Basin Sheet have been excerpted from the earlier published Explanatory Notes for the four Quadrant Maps. For more detail the reader is referred to the Explanatory Notes accompanying the 1:10,000,000 Energy-Resources maps for the four quadrants.

The Energy-Resources Map of the Circum-Pacific Region, Northeast Quadrant was prepared under the direction of Panel Chairman Kenneth J. Drummond, Mobil Oil Canada, Calgary, Alberta, Canada. The major compilation was completed by Drummond and Paul W. Richards, formerly of the U.S. Geological Survey, Reston, Virginia, with the assistance and advice of Northeast Quadrant panel members and with contributions for the overlap area with the Southeast Quadrant (South American continent), provided by José Corvalán D., Santiago, Chile, Southeast Quadrant Panel Chairman, and Marcelo Yrigoyen, Exxon, Argentina, coordinator of the Energy-Resources Map of the Southeast Quadrant. Other principal investigators and sources of data are indicated in the references section on the map sheet and in the bibliographic references. The Northeast Quadrant panel (1986) was composed of the following members: Prasada Rao, Belize; R.L. Chase, Kenneth M. Dawson, Hubert Gabrielse, and Geoffrey B. Leech, Canada; R. Castillo M. and F. Rudín, Costa Rica; Julio Salazar, El Salvador; Gabriel Dengo, and Oscar Salazar, Guatemala; José Maria Gutiérrez, Honduras; Guillermo P. Salas, Mexico; Mauricio Darce and Glen Hodgson, Nicaragua; Julio Mérida, Panama; James E. Case, Philip W. Guild, Allen Lowrie, Ray G. Martin, George W. Moore, and David W. Scholl, United States. The Explanatory Notes for the Energy-Resources Map of the Northeast Quadrant were translated into Spanish by Gerardo Soto, Escuela Centroamericano de Geologia, Universidad de Costa Rica, San José, Costa Rica. The section on Geothermal Resources was written by Theresa R. Swint-Iki.

The Energy-Resources Map of the Circum-Pacific Region, Southeast Quadrant was prepared under the direction of Panel Chairman José Corvalan D., Servicio Nacional de Geologia y Mineria, Santiago, Chile, plus the coordination of General Chairman George Gryc and the technical advice of Warren $O$. Addicott and Theresa R. Swint-Iki. The major compilation was carried out by Marcelo R. Yrigoyen, Trend Argentina, S.A., Buenos Aires, Argentina (formerly with Esso Exploration Inc., Buenos Aires, Argentina) with the assistance and advice of the Southeast Quadrant Panel members. For the overlap area with the Northeast Quadrant, information from the Energy-Resources Map of that quadrant, compiled by Kenneth $J$.
Drummond, Mobil Oil of Canada, Calgary, Alberta, Canada, was used. Other principal investigators and sources of data are indicated in the references sections of the maps Sheet 1, Resources, and Sheet 2, Sedimentary Basins, and in the references included herein.

The Energy-Resources Map of the Circum-Pacific Region, Northwest Quadrant was prepared under the direction of the present Panel Chairman Tomoyuki Moritani, formerly of the Geological Survey of Japan, and the previous chairman Eiji Inoue, formerly of the Geological Survey of Japan. The final compilation of the map was coordinated by Tomoaki Sumii, Koji Wakita, Osamu Matsubayashi, and Keizo Fujii, all of the Geological Survey of Japan, with the assistance and advice of past and present Northwest Quadrant panel members and the staff of the Geological Survey of Japan, notably by Yoshiaki Sato, Kazuo Hoshino, Eiichi Honza, Manabu Tanahashi, Koichi Nakamura, Yasufumi Ishiwada, Yataka Ikebe, and Shunichi Sano. The contributions of Zhai Guangming of the Research Institute of Petroleum Exploration and Development, People's Republic of China, and Chong Su Kim of the Korean Institute of Energy Resources are acknowledged with appreciation. Kenneth J. Drummond, Mobil Oil Company of Canada, contributed to Table 2 of these notes, and Theresa R. Swint-Iki, U. S. Geological Survey, contributed to the index maps and tables in these notes. Other principal investigators and sources of data are indicated in the references section on the map sheet and in the bilbliographic references that follow. Affiliations represent time of compilation.

The Energy-Resources Map of the Circum-Pacific Region, Southwest Quadrant was compiled under the direction of Panel Chairman, R. W. Johnson and by W. David Palfreyman, both of the Australian Geological Survey Organisation (AGSO). Energy-resources data were compiled from a number of geoscience maps of various scales produced by AGSO, Australian State and Territorial government geoscience organizations, similar organizations in the southwest Pacific region, and various private companies and universities.

\section{BACKGROUND INFORMATION}

\section{LAND AREAS}

The background data on land are generalized from the $1: 10,000,000$-scale geologic maps of the four Quadrants. Significant tectonic and lithologic units have been combined into only seven divisions. The classification is designed to show the significance of host-rock units or terranes to the occurrence of energy resources. The background units are depicted in pale colors so as not to detract from the resource 
data. The faults depicted are selected and updated from the Plate-Tectonic Map (Drummond, 1981).

The background units include ultramafic rocks, crystalline basement rocks, Late Proterozoic and Phanerozoic continental margin rocks, metamorphic complexes, intrusive igneous rocks of Phanerozoic age, volcanic cover, and major sedimentary basins and platform deposits.

\section{Crystalline basement}

The basement terrane variously comprises crystalline Precambrian rocks, both on the shields and within the Cordillera, Precambrian sedimentary rocks, Cordilleran metamorphic complexes, oceanic basement terrane, accreted island-arc terrane, and igneous intrusions. The rocks classified as crystalline basement include mixed felsic and mafic gneisses, granitoid and more mafic intrusive rocks, and "greenstone belts" of stratified sedimentary and volcanic rocks. Formed over a period of some two billion years, in Archean and Early Proterozoic time, they had a long history of deformation and, in places, repeated metamorphism. Orogenic activity was essentially completed by the end of the Early Proterozoic. Since then, except for minor faulting and some post-orogenic intrusive and extrusive magmatism, slow warping and erosion have been the dominant geologic processes in those areas of the exposed shields of the CircumPacific Region. The basement extends at fairly shallow depths under the broad zones of platform cover rocks adjacent to the shields.

\section{Continental margin rocks of Late Proterozoic and Phanerozoic age}

Late Proterozoic rocks are supracrustal, largely clastic sediments derived by erosion from the now stabilized crystalline basement, although carbonate sediments constitute significant proportions in some places. Volcanic rocks are minor and related to continental rifting. On and near the exposed shields, the outcrop patterns are roughly equidimensional, reflecting the undeformed flat-lying character of the rocks that comprise them, whereas along the margins of the Cordillera, rocks of this age are exposed in linear belts that resulted from orogenic activity (folding, faulting, uplift, and erosion) of later geologic time. Metamorphism is generally absent to low grade, although in places it reaches higher grades. Some of the rocks shown on the map as metamorphic complexes are known to include rocks of Proterozoic age metamorphosed in Phanerozoic time.

\section{Metamorphic complexes}

Areas shown as metamorphic complexes include a variety of rocks ranging in age from late Precambrian to
Tertiary that were highly deformed, metamorphosed, and in places intruded by granitoid rocks during one or more Phanerozoic orogenies. They range from blueschist or greenschist facies up to and including gneiss. Their relationship is not always certain; at least some may be allochthonous (accreted).

\section{Intrusive igneous rocks}

Intrusive rocks ranging in age from Paleozoic to Tertiary, and in composition from gabbro to granite and syenite, are widespread and abundant around the Pacific margin. Most of the major batholiths are of Mesozoic or Paleogene age and have an average composition of granodiorite. In detail, however, they are composite and resulted from repeated magmatic events over extended periods of time. For example, intrusions in the Sierra Nevada occurred from Triassic to Late Cretaceous (Evernden and Kistler, 1970). Intrusive rocks are less abundant and individual plutons generally are much smaller east of the main batholithic belt.

\section{Volcanic rocks}

This map unit essentially shows only the extensive plateau basalts and other volcanic cover where the nature of the underlying rocks is unknown. The Volcanic rocks around the Pacific range in age from Proterozoic to Cenozoic, and in composition from rhyolite to basalt.

\section{Sedimentary basins and platform deposits}

Sedimentary basins are shown by sediment isopachs, colored to indicate the age of the oldest major sedimentary unit above basement. The age and lithology of the basement is generally indicated by the surrounding bedrock geology. Representative stratigraphic sections showing the generalized stratigraphy of many of the basins of the CircumPacific region are included in the notes (fig.17).

\section{Ultramafic rocks}

The ultramafic rocks are a distinctive class of magnesium- and iron-rich intrusive rocks that, in plate-tectonic theory, represent mantle rocks brought to the surface at accreting margins (or perhaps at primitive island arcs) and incorporated into land areas at convergent margins. They form the basal member of the typical ophiolite suite, below the gabbro, pillow basalts, possible massive sulfide deposits, and cherts, from which they may be separated by the shearing that accompanies the convergence. Ultramafic rocks are widely distributed in the orogenic belts around the Circum-Pacific region. 


\section{OCEAN AREAS}

The basic background for oceanic regions is bathymetry printed in a light blue tint. Overprinted on this are sediment isopachs, colored to indicate the age of the underlying oceanic crust. The oceanic crustal age mapping from which the isopach coloration was derived was completed by Xenia Golovchenko, then of Lamont-Doherty Geological Observatory, as an unpublished part of the magnetic lineation compilation for the Plate-Tectonic Map of the Pacific Basin (Glovchenko and others, 1981). Also shown are the major active plate boundaries.

\section{GEOLOGIC SETTING}

\section{NORTHEAST QUADRANT}

The chief tectonic features within the Northeast Quadrant map area are: (1) parts of two shields (continental nuclei)- the Canadian and Guyana; (2) broad belts of essentially undeformed, younger sedimentary rocks that constitute platform cover over the shields; and (3) the Cordillera (sensu lato), a complex zone of sedimentary and extrusive and intrusive igneous rocks that extends along the entire margin of the continents facing the $\mathrm{Pa}$ cific Ocean and even into the Atlantic along the Greater and Lesser Antilles. The Cordilleran zone has been involved in interactions between continental and oceanic plates at least since late Paleozoic time and possibly longer. Much of it is now interpreted as a collage of fragments that originated elsewhere and were accreted to the craton by plate motions.

\section{SOUTHEAST QUADRANT}

Following the guidelines of the Commission for the Geologic Map of the World for the Tectonic Map of South America (United Nations Educational, Scientific, and Cultural Organization (UNESCO), 1978), the area covered by the Southeast Quadrant can be divided into three tectonic regions that differ in origin, age, and structural evolution. The oldest, the South American Platform, constitutes the entire central area and most of the eastern part of the continent. It includes all of Brazil, Paraguay, Uruguay, Guiana, French Guiana, and Suriname, as well as the central and southern regions of Venezuela, eastern Colombia, Ecuador, Peru, Bolivia, and the northern part of Argentina. It is an old platform in which the basement was consolidated during the end of the Precambrian and the Cambrian. It contains the only Archean rocks of the continent. Deposition of the sedimentary cover and the associated volcanic rocks started in the Silurian. These rocks are found mainly in the four great downwarps of Paraná, Chaco, Amazon, and Parnaiba, as well as in the sedimentary prism flanking the Andes along the west margin of the platform. Smaller areas of sedimentation are found on the major shields where basement rocks of the platform crop out.

The Patagonian Platform is located entirely within Argentina and extends along the large continental-shelf margin. Younger in age, basement consolidation started in the middle part of the Paleozoic, but the platform was almost entirely masked by a volcanic-sedimentary cover developed from the Carboniferous onward.

These two platforms are bounded on the west by the large fold belt of the Andean Cordillera and the Caribbean Mountains, the latter developed on the northern edge of the South American Platform. These extensive belts show a persistent crustal mobility from at least late Precambrian until recent time. During the Phanerozoic, their polycyclic evolution occurred mostly over sialic crust.

The boundaries between these large tectonic regions are still poorly known partly due to insufficient geologic study but mainly owing to the Mesozoic and Cenozoic sedimentary cover. The Precambrian basement of the South American Platform is widely exposed in the Southeast Quadrant, both as large massifs and in smaller sporadic outcrops. The Patagonian Platform crops out in the North Patagonian, Deseado, and Malvinas (Falkland) Islands massifs, with extensions in the Dungeness Arch and even in the Eastern Patagonian Ridge, both extensions beneath the Argentine epicontinental sea. The Patagonian Platform basement is composed of metamorphic rocks and sediments of late Precambrian and early Paleozoic age, as well as Precambrian, Permian, and Triassic extrusive rocks and late Paleozoic granitic intrusive rocks. Several subsiding stages with resultant continental and marine sedimentation took place from the early Mesozoic until the tectonomagmatic reactivation in the Late Jurassic. Since then, large areas of the Patagonian Platform appear as molassic forebasins of relative tectonic stability that were modified only by epeirogenic movements and strong Cenozoic mafic volcanism.

The third great constituent of the continent is the Andean Cordillera and the Caribbean Mountains, where remnants of metasedimentary and metavolcanic rocks of polyphase evolution are assigned to the late Precambrian. The folded belt of the Andean Cordillera developed over a rifted continental margin during the final stages of the Precambrian (and into the Cambrian) with partial remobilization of the older terrain, including that of the Trans-Amazonian Cycle (2000 $\mathrm{Ma})$. The elongated Andean Ranges show strong $\mathrm{Pa}-$ leozoic and Mesozoic structures with dominant Ceno- 
zoic tectonism accompanied by significant intrusive and volcanic episodes.

In the Caribbean Mountains, which developed during terrane accretion, extensive late Mesozoic and Cenozoic sedimentation took place between blocks of submarine ophiolitic volcanic rocks. Andean tectonism was the dominant feature during Neogene molassic deposition in the intermontane troughs. Terrane accretion and sedimentation were accompanied by emplacement of granitic plutons; mafic and ultramafic rocks, including serpentinitic peridotites, were brought to the surface.

The most outstanding features of the eastern Pacific Ocean are the large fracture zones trending east-west, which have been depicted on bathymetric maps. Recent magnetic and SEASAT gravity maps show these features with considerable detail. The major components are oceanic spreading axes, aseismic ridges, major trenches (interpreted as subduction zones), and large active transform strike-slip fault zones such as the Udintsev, Eltanin, Tula, Menard, Taitao, Guafo, Valdivia, Challenger, Mendana, Wilkes, Quebrada, Galápagos, Siqueiros, and Clipperton. Initial formation of southeastern Pacific marginal basins occurred in the final stages of the Middle and Late Jurassic orogeny. Most of these basins developed along the juncture of continental and oceanic crusts within a convergent tectonic framework characterized by volcanism and plutonism with associated underthrusting and strike-slip transcurrent movements (Drummond, 1986).

\section{NORTHWEST QUADRANT}

The continental part of the Northwest Quadrant Map area is an assemblage of continental blocks surrounded by Phanerozoic fold belts. The major continental blocks are parts of two Archean shields (Siberian Platform and North China Platform) and four major Proterozoic blocks (Yangtze Platform, Kontum Platform, Bureya Massif, and Kolyma Massif). The continental blocks are covered by essentially undeformed, younger sedimentary rocks. Phanerozoic fold belts are ancient accretionary complexes, including oceanic materials, microcontinents, and remnant island arcs. The fold belts contain the extrusive and intrusive rocks which are related to subduction. Subduction, collision, and accretion are the main cause of the geologic features in the Northwest Quadrant Map area.

\section{SOUTHWEST QUADRANT}

The geological background has been generalized from the Geologic Map of the Circum-Pacific Region, Southwest Quadrant (Palfreyman, 1988). Significant tectonic and lithological units have been combined to form seven major groups:

Major sedimentary basins, platform deposits, and surficial deposits. These are generally thick deposits of sediment that show little to no deformation. They range in age from Proterozoic to Cenozoic. This area contains the vast majority of the coal, oil, gas, and oil shale deposits in the Southwest Quadrant region.

Volcanic rocks. These range in age from Proterozoic to Cenozoic and are found throughout the Australian continent. They are especially concentrated along the convergent plate boundaries to the north and east of Australia. Areas of undivided igneous rocks, mixed volcanic and intrusive igneous rocks, confined to the Indonesian island of Sumatra are included in this category.

Phanerozoic fold belts and deformed basinal deposits. These consist of belts of deformed and metamorphosed sedimentary and igneous. rocks and are concentrated in the east and south of the Australian continent, in the eastern part of the Papua New Guinea mainland, and in the South Island of New Zealand.

Precambrian mobile zones and deformed platform cover deposits. These consist of belts of rocks similar to those of Phanerozoic age. They are found in the western and central parts of the Australian continent.

Metamorphic complexes. Mostly Precambrian. These are areas of moderate- to high-grade metamorphic rocks that are located in central and western Australia.

Intrusive igneous rocks. These range in age from Precambrian to Cenozoic and in composition from felsic to ultramafic. They are distributed widely throughout the map sheet area.

\section{TECTONIC SETTING}

The plate-tectonic framework of the Pacific basin is shown in figure 1 . The major plates include the North America, South America, Antarctica, Australia-India, and the Eurasia continental plates, the main Pacific Plate and the minor oceanic plates, Phillipine, Nazca, Cocos, Scotia, Caribbean, and Juan de Fuca. A major feature of the Pacific Plate are the long linear east-west fracture zones, which segment the Pacific Basin. Superimposed on the overall tectonic grain are chains of volcanic islands, including the Hawaiian, Welker-Kodiak, Marquises, and the Line Islands. The boundaries of the major lithospheric plates for the $\mathrm{Pa}$ cific Basin are printed in red on the Energy Resources Map. They are delineated by spreading axes, major trenches that are interpreted to be the sites of subduction zones, and large strike-slip faults (active transforms).

The basic framework for the marginal basins of the Pacific began with the waning stages of Middle to late Jurassic orogenies. Most of the sedimentary basins of 
the Pacific margin developed along the junction of continental and oceanic crust, within a convergent regime, characterized by volcanism and plutonism, with associated underthrusting and strike-slip movements. Pacific margin trough basins developed in general over a thick and complex sequence of Mesozoic sedimentary, metamorphic, and intrusive and extrusive rocks possibly representative of an older arc-trench system. Structurally complex late Mesozoic deep-water graywacke, argillite, and radiolarian chert, with associated pillow basalt, gabbro, and ultramafic rocks, occur all along the Pacific margin.

The Pacific basin is highlighted by the Ring-of-Fire, a belt of volcanic and igneous intrusive rocks circling the Pacific Ocean. Sedimentary basins are developed marginal to the oceanic basins, within the magmatic belts, and within the cratonic interior.

\section{NORTHEAST QUADRANT}

The major plates of the northeast Pacific region are: the North America and South America continental plates, the main oceanic plate - the Pacific - and minor oceanic plates - the Caribbean, Cocos, Nazca, and Juan de Fuca. Major features of the northeast Pacific Ocean are the long linear east-west fracture zones, which have been recognized for some time on bathymetric maps. More recently they have been delineated on magnetic and SEASAT gravity maps. The boundaries of the major lithospheric plates in the Northeast Quadrant are printed in red on the Energy Resources Map. They are delineated by spreading axes, major trenches that are interpreted to be the sites of subduction zones, and large strike-slip faults (active transforms). The basic framework for the marginal basins of the northeast Pacific began with the waning stages of Middle to Late Jurassic orogenies. Most of the sedimentary basins of the Pacific margin developed along the junction of continental and oceanic crust, within a convergent regime, characterized by volcanism and plutonism, with associated underthrusting and strike-slip movements.

Pacific-margin trough basins developed in general over a thick and complex sequence of Mesozoic sedimentary, metamorphic, and intrusive and extrusive rocks possibly representative of an older arc-trench system. Structurally complex late Mesozoic deep-water graywacke, argillite, and radiolarian chert, with associated pillow basalt, gabbro, and ultramafic rocks, occur all along the Pacific margin. They extend for a distance of about $12,800 \mathrm{~km}$ from Ecuador to Alaska. This deepwater complex can be traced from the Santa Elena Peninsula, Ecuador, to western Colombia, thence to Costa Rica, and on to the Viscaino Peninsula, Mexico; then it continues through the California Coast Ranges and southwestern Oregon to the San Juan Islands and the west coast of Vancouver Island; and finally it includes Baranof and Chicagof Islands of southeast Alaska, the Chugach Range of southern Alaska, and Kodiak and Shumagin Islands.

\section{SOUTHEAST QUADRANT}

The plate-tectonic framework of the Southeast Quadrant comprises the large South American continental plate and the Pacific and Antarctica oceanic plates. Smaller oceanic plates include the Caribbean, Cocos, Nazca, and Scotia Plates (Corvalán, 1981). The limits of the largest lithospheric plates of the Southeast Quadrant are shown in red. The most outstanding features of the eastern Pacific Ocean are the large fracture zones trending eastwest, which have been depicted on bathymetric maps. Recent magnetic and SEASAT gravity maps show these features with considerable detail. The major components are oceanic spreading axes, aseismic redges,- major trenches (interpreted as subduction zones), and large active transform strike-slip fault zones such as the Udintsev, Eltanin, Tula, Menard, Taitao, Guafo, Valdivia, Challenger, Mendana, Wilkes, Quebrada, Galapagos, Siqueiros, and Clipperton. Initial formation of southeastern Pacific marginal basins occurred in the final stages of the Middle and Late Jurassic orogeny. Most of these basins developed along the juncture of continental and oceanic crusts within a convergent tectonic framework characterized by volcanism and plutonism with associated underthrusting and strike-slip transcurrent movements (Drummond, 1986).

\section{NORTHWEST QUADRANT}

The major plates of the northwest Pacific region are the North America Plate, the Eurasia Plate, the Philippine Plate, the Pacific Plate, and the Australia-India Plate. In addition, some minor plates are subdivided and identified. Several models have been proposed for the plate boundary between the North America Plate and the Eurasia Plate, but none have been fully accepted.

Along the east margin of the Asian continent and adjacent to the Philippine Sea, lie a series of trench-island arc-marginal sea systems. The Himalaya Orogenic Belt and Sunda Arc constitute the convergent belt between the Eurasia Plate and the Australia-India Plate. Around the Banda Sea, three major plates converge: the southeast tip of the Eurasia Plate, the south tip of the Philippine Plate, and the Australia-India Plate. The interaction between these three plates has created the complicated island-arc systems in this region.

The Pacific Plate converges onto the Australia-India 
Plate along the New Guinea Fold Belt and Bismark Archipelago, and along the Solomon Islands.

The Eurasia continent is composed of several continental blocks made up of platforms and massifs amalgamated along suture zones or fold belts. These suture zones are interpreted as the ancient plate boundaries. The development of sedimentary basins in this region is controlled by the interaction of these continental blocks.

\section{SOUTHWEST QUADRANT}

The Pacific Plate, Australia-India Plate, Eurasia Plate, Philippine Plate, and the Antarctica Plate are the major structural features of the Southwest Quadrant. Smaller structures such as the Burma, Mariana, Bismarck, and Solomon Plates lie between the main plates.

The Pacific Plate is moving in a general northwesterly direction from spreading axes in the eastern and southern Pacific at a rate of between 8 and $11 \mathrm{~cm}$ per year. It dips beneath the Philippine Plate in the north of the sheet area along the Mariana Thrust and beneath the Australia-India Plate along a complex series of thrusts and shears between New Guinea in the north and New Zealand in the southwest. Similarly, the Philippine Plate is dipping beneath the Eurasia Plate along the Mindanao Thrust. The Australia-India Plate is moving northwards away from spreading axes in the Southern Ocean at a rate of $8 \mathrm{~cm}$ per year and dips beneath the Eurasia Plate along the line of the Sunda and Timor Thrusts. The interaction between the Eurasia, Pacific, and Australia-India Plates has created a complex series of thrusts, shears, and minor plates in the Andaman, Banda, Bismarck, and Solomon Sea regions.

The Pacific Plate is composed almost entirely of oceanic crust overlain by Mesozoic to Cenozoic sediments, whereas the other major plates have substantial areas of continental crust (for example, the Eurasian continent, Australia and parts of New Zealand, and Antarctica). These continental masses consist of blocks of generally Precambrian age separated by younger fold belts and overlain by sedimentary basins of varying types.

\section{ENERGY RESOURCES}

\section{OIL AND NATURAL GAS}

The main oil and gas fields of the Pacific Basin are plotted as close to real scale and location as possible. Some of the smaller fields, of necessity, have been enlarged slightly, and in some areas several small fields in close proximity have been grouped as one. Oil fields are shown with a solid green color, and gas fields are shown in solid red. Note that a significant portion of the known oil and gas resources of the Pacific Basin area occur within the interior of the continental plates. Estimated reserves of oil and gas for countries of the Pacific Basin are shown in table 1 . The 1998 oil and gas production for countries of the Circum-Pacific region is shown in table 2.

Index maps showing sedimentary basins and location of selected oil and gas fields are taken from the explanatory notes of the four quadrants and are included as figures 2 through 16. The data on the giant and selected major oil and gas fields for the Pacific Basin Map area is available in the tables of the various quadrants. These tables are included herein, and have been updated, where information is available, to a more recent date. Included in the tables 4 through 16 are the year of discovery, reservoir age and lithology, average producing depth, cumulative production (various dates), and the estimated ultimate recovery for many of the fields.

\section{Northeast Quadrant}

For the Northeast Quadrant giant fields contain approximately 43 percent of the total initial established reserves. The major portion of the reserves are in the continental interior basins where there are a total of 13 basins, which contain fields with greater than 500 million barrels of oil or 3 trillion cubic feet of natural gas.

\section{Sedimentary Basins of the Northeast Quadrant}

The basin index map (fig. 2) shows the names of the major basins in the Northeast Quadrant. The sedimentary basins can be classified as interior basins (cratonal and foreland), intramontane or fold-belt basins, and marginal basins (either directly or indirectly related to oceanic areas). The interior platforms of North and South America comprise a westward-thickening wedge of sediments ranging from a wedge edge where they onlap the shields to thicknesses of 7 to $11 \mathrm{~km}$ along the front of the Cordillera. The basin areas are formed by a series of large asymmetric depressions between the Cordillera and the shields, separated by basement arches, some of which are related to basement uplift.

The westward-thickening wedge of platform sediments is episodically deformed and uplifted in the Cordillera. Sediments are derived from Cordilleran uplifts, so as to increase basin subsidence, and further accentuate the basins along the mountain fronts. These basins are often referred to as foreland basins. One area with extensive uplift and foreland deformation is the Rocky Mountain region in the United States. The region could be considered as an unstable platform basin area.

The intramontane basins are sedimentary basins that occur within the major Cordilleran uplifts. Sediments were deposited in basins that developed within the Cor- 
dillera by localized subsidence, both during and after the major deformation. These basins developed from the midJurassic to the late Tertiary.

Basins of the continental margin include all basin areas bordering the North and South American continents. These include the circum-Pacific basins, circum-Arctic Ocean basins, Bering Sea basins, Gulf of Mexico basins, and the circum-Caribbean basins. Only the circumPacific basins of the Northeast Quadrant will be considered in the following discussion. Figure 3 is a series of generalized sections illustrating the structural setting of selected Pacific margin basins.

Thick post-orogenic sequences are deposited in basins along the northeast Pacific continental margin. Both continental and shallow-marine sedimentary facies are present. Age of sediments range from middle Mesozoic to late Cenozoic.

Among the most characteristic expressions of the circum-Pacific region are the trenches that mark subduction zones and associated volcanic chains. Along the northeast Pacific margin, continuous accretionary subduction has been underway since about mid-Cenozoic. The shelves are typically narrow, commonly with steep slopes. Deltaic complexes are relatively small, and turbidite assemblages are widespread.

The continental-margin basins of the Northeast Quadrant extend some $12,800 \mathrm{~km}$ from northeast Peru to the Alaska Peninsula. The presently productive basins that are mainly offshore include: Cook Inlet, Sacramento, San Joaquin, Santa Maria, Salinas, Ventura, Los Angeles, Daule, Progreso, and Talara. Other basins with minor production include western Washington, Eel River, and Santa Cruz.

Examples of basins at the northeast continental margin are Cook Inlet basin, basins of the Gulf of Alaska, western Canada offshore basins, offshore western United States, and the Middle America marginal-trough basin.

\section{Cook Inlet Basin}

Cook Inlet Basin is a fault-bounded basin, $320 \mathrm{~km}$ long by $100 \mathrm{~km}$ wide. The basin is located in an arctrench-gap setting between the volcanic arc represented by the volcanic and intrusive igneous rocks of the southern Alaska Range and a deformed Upper Cretaceous wedge of sediments to the southeast. Basin fill comprises rocks of Middle and Late Jurassic, Late Cretaceous, and Tertiary ages. The Lower Cretaceous section has been removed by mid-Cretaceous erosion. Upper Cretaceous rocks are mainly marine shale with only minor sandstone. The main basin fill is composed of thick Tertiary alluvial clastics of the Kenai Group.

The major oil and gas fields are located on north-trending anticlines.
Basins of the Gulf of Alaska

The continental margin of the central and eastern part of the Gulf of Alaska contains up to $10 \mathrm{~km}$ of Cenozoic sediments compressionally deformed by the subducting Pacific plate. The western Gulf of Alaska contains several basins with 2 to $6 \mathrm{~km}$ of Neogene sediments overlying older, more deformed Tertiary and Mesozoic rocks. The basins include Sanak, Shumagin, Tugidak, Albatross, and Stevenson. Sanak and Shumagin are small uplifted continental-slope basins containing late Miocene and younger rocks. Maximum thickness of sediment is possibly 2 to $3 \mathrm{~km}$ in Sanak and Shumagin basins.

The Kodiak Shelf offshore from Kodiak Island includes three basins - Tigidak, Albatross, and Stevenson separated by structural highs. The north flank of the basins is marked by a wide zone of faults bounding the uplifted block of Kodiak Island. The seaward side is an asymmetric arch at the edge of the shelf about $115 \mathrm{~km}$ long and covered by as little as $16 \mathrm{~m}$ of water. Pliocene sediments comprise the main basin fill and may be as old as middle Miocene. The Pliocene is generally 3 to $3.5 \mathrm{~km}$ thick and possibly up to $7 \mathrm{~km}$ in Stevenson basin.

\section{Western Canada Offshore Basins}

The British Columbia offshore basins stretch 1,000 $\mathrm{km}$ from Dixon Entrance (between the Queen Charlotte Islands and southeast Alaska) in the north to the Strait of Juan de Fuca in the south. The major basins include Queen Charlotte, Tofino, and Winona.

\section{Queen Charlotte Basin}

The Queen Charlotte basin contains up to $4.5 \mathrm{~km}$ of Miocene to Pleistocene terrigenous clastics, predominantly nonmarine. The basin is probably floored by Jurassic and older intrusive and volcanic rocks with minor sediments, typical of the insular volcanic belt. Basement along the east is composed of plutonic and metamorphic rocks of the Coast Mountains. Along the west, the margin is formed by the tectonically emplaced "Pacific Rim" sequence. Development of the basin began in earliest Cretaceous time with the deposition of continental-shelf deposits of graywacke, argillite, and conglomerate. Northeastward tilting of the shelf was followed by the deposition of shallow-marine sediments during the Late Cretaceous. At the end of the Cretaceous or early Tertiary the Pacific Rim sequence of Upper Jurassic to Lower Cretaceous deep-water sediments was tectonically emplaced. Eocene and Oligocene sediments may have been deposited on the shelf; these are overlain by volcanics. Major Tertiary sedimentation began during the Miocene, interrupted by perhaps two periods of uplift and erosion, and 
continued through the Pliocene into the Pleistocene. Volcanics encountered in wells in the Queen Charlotte basin possibly were erupted during or immediately following the change in plate motion, convergence to translation, that took place about $10 \mathrm{~m}$.y. ago, related to the widespread middle to late Miocene unconformity along the Pacific margin of western North America.

\section{Tofino Basin}

The Tofino basin contains a thick sequence of late Eocene to Pliocene rocks, primarily distal-facies mudstone and siltstone. The pre-Tertiary consists of a thick complexly-deformed sequence of Mesozoic sedimentary, metamorphic, intrusive, and extrusive rocks. A widespread submarine-volcanic event occurred in the early part of the middle Eocene. Initial subsidence occurred in the late Eocene, with major transgression in the Oligocene and early Miocene. Major uplift and regression occurred in the middle Miocene. Another major transgression of the sea occurred in the late Miocene, lessening in the early Pliocene. A major regressive phase followed in the late Pliocene to Pleistocene. Eocene to Oligocene rocks occur in a belt along the inner shelf, with Miocene and Pliocene rocks occurring mainly seaward.

\section{Winona Basin}

The Winona basin, with 3 to $5 \mathrm{~km}$ of Plio-Pleistocene sediments, lies at the base of the continental slope. The sedimentary succession is gently and broadly folded at the north, but deformed into prominent ridges at the south. The oldest sediments of the west flank, on the Paul Revere Ridge, are Pliocene, as indicated by Deep Sea Drilling Project (DSDP) hole 177A. The deepwater Winona basin most likely received a high proportion of second-cycle clastic deposits from the uplifted older Tertiary belt to the east.

\section{Offshore Pacific Coast of United States}

The basins of the Pacific offshore of the United States developed over a pre-middle Miocene unconformity. In general these basins developed on a surface consisting of a deformed sequence of Mesozoic sedimentary, metamorphic, and intrusive and extrusive igneous rocks.

\section{Offshore Oregon and Washington}

In northwestern Washington, oceanic basalt of Eocene age has been thrust onto the continental crust. This suggests a maximum age for the sedimentary section of offshore Washington. Western Oregon and Washington were the sites of thick sedimentation during early Cenozoic time with the accumulation of up to $8 \mathrm{~km}$ of sediment. Intense tectonism occurred during the late Eocene. The Coast Range was uplifted in the late Oligocene, and deposition shifted westward into the structural basins of the present continental shelf.

Offshore from Oregon and Washington a sedimentary basin occurs as an elongate trough, extending along the margin from Cape Blanco north to merge with the south end of the Tofino basin off Vancouver Island. Depocenters occur northwest of Coos Bay, off the mouth of the Columbia River, and off the southwestern part of the Olympic Peninsula. Within this elongate trough there is a sedimentary section of marine sandstone and siltstone of Eocene to Pliocene age as much as $8 \mathrm{~km}$ thick.

About 560 wells have been drilled in western Oregon and Washington with only about 70 drilled deeper than $1,500 \mathrm{~m}$. Only 13 wells have been drilled offshore.

\section{Northern and Central California}

The continental shelf off northern and central California is characteristically narrow at Point Arguello (lat $34^{\circ} 30^{\prime} \mathrm{N}$.) north. A deformed blanket of late Cenozoic sediments underlies the continental shelf and crops out in patches along the coast. Outcrops at Eureka (lat $45^{\circ} 45^{\prime} \mathrm{N}$.) record a late Miocene transgression and marine deposition during the Pliocene. Regression occurred in the late Pliocene, with deposition of coarse nonmarine clastics in the early Pleistocene.

There are five sedimentary basins along the Pacific margin of central and northern California from Point Arguello north to the California-Oregon border. The basins from north to south are Eel River (including onshore), Point Arena, Bodega, Ano Nuevo, and offshore Santa Maria. The onshore portion of the Eel River basin has recorded minor gas production from Miocene beds, and minor oil production has been obtained from the onshore extension of the Ano Nuevo basin.

\section{California Borderland}

The California continental borderland, a subsea geomorphic province, is an elongate region lying shoreward of the $3 \mathrm{~km}$ isobath that extends from point Conception (lat $34^{\circ} 30^{\prime} \mathrm{N}$.) to Isla Cedros (lat $28^{\circ} \mathrm{N}$.). The region is characterized by a highly irregular submarine topography of basins and ridges. There are about 19 major topographic basins ( 35 to $135 \mathrm{~km}$ long by 8 to $35 \mathrm{~km}$ wide) with water depths ranging from 200 to $3,000 \mathrm{~m}$. The seaward boundary of the borderland is marked by a steep continental slope known as the Patton Escarpment in its northern part.

The borderland owes its origin to a position on the Pacific plate near the northern termination of the East 
Pacific Rise where motion of the Pacific plate changes to extension along major strike-slip faults. The dominant structural control in the borderland is a wrench-fault system. The origin and history of the southern California basins has been ably discussed by Crowell (1974).

Middle Miocene sedimentary and volcanic rocks occur in most of the area and at one time may have covered it entirely, with deposition over a broad shelf with volcanic centers. This shelf subsided uniformly with the accumulation of $2.5 \mathrm{~km}$ or more of middle Miocene sediments and volcanics. Near the end of the middle Miocene the shelf was folded, faulted, and broken up into basins in which siliceous and phosphatic shales were deposited in seaward areas. Sandstone, shale, and breccia were deposited in landward areas. Offshore basinal deposition began early in late Miocene time.

Clastic material was derived for the most part from the mainland and was distributed by turbidity currents. These depositional processes have continued to the present.

California offshore basins, once part of a regional $\mathrm{Pa}$ cific basin, became separated as a result of the Neogene transform movements and are now elongate deep basins separated by uplifts of Mesozoic and older rocks. The four Tertiary basin areas include the San Diego trough, offshore Los Angeles, the Outer Banks, and the VenturaSanta Barbara Channel.

The San Diego trough is a broad basin filled with up to $3 \mathrm{~km}$ of Tertiary sediments derived from Mesozoic metasediments and granitic intrusions.

The Outer Banks basins contain mainly Upper Cretaceous and Eocene-Oligocene clastics 2 to $3 \mathrm{~km}$ thick. Miocene-Pliocene sediments are absent or thin on the crests of major structural highs and up to $1.5 \mathrm{~km}$ thick in the basin deeps.

\section{Onshore Southern California Basins}

The most significant productive basins of the Northeast Pacific Margin occur in California. The onshore basins include Sacramento, San Joaquin, Salinas, Santa Maria, Ventura, and Los Angeles. Production for the Santa Maria, Ventura, and Los Angeles basins extends into the offshore area.

The Sacramento and San Joaquin basins occupy the Great Valley of California, bounded on the east by the Sierra Nevada and on the west by the western margin. The basins are an asymmetric structural trough with the axis near and parallel to the western margin. The two basins are separated by the Stockton arch fault zone in the subsurface. The Sacramento basin, $450 \mathrm{~km}$ long by $100 \mathrm{~km}$ wide, contains Upper Cretaceous and Tertiary sediments, which thicken from north to south to about 7 $\mathrm{km}$. The basin is essentially a dry-gas producing area with production from Upper Cretaceous and Tertiary sands.

The San Joaquin basin, $410 \mathrm{~km}$ long by about 100 $\mathrm{km}$ wide, contains a thick Upper Cretaceous and Tertiary section, which reaches a thickness of at least 12 $\mathrm{km}$ in the southwest part. Production from the basin is primarily oil with significant associated gas. Productive sands occur from the Upper Cretaceous to the Pliocene with most of the production from Miocene and younger formations.

The Salinas-Cuyama basin is a coast-parallel ba$\sin , 250 \mathrm{~km}$ long by $45 \mathrm{~km}$ wide, lying to the west of the San Joaquin basin. The basin is bounded to the northeast and southwest by major strike-slip faults. The area is underlain by granitic basement and contains a relatively thin section of about $2 \mathrm{~km}$ of lower Miocene to lower Pliocene clastic rocks. The largest field is San Ardo, producing from Miocene sandstone.

The Santa Maria basin is a triangular-shaped area in the California coastal belt. It is bounded by mountain ranges to the northeast and the south and extends into the offshore to the west. The basin contains up to $2 \mathrm{~km}$ of Tertiary clastics. Principal production is from the fractured shale of the Monterey Formation with some production from Miocene and Pliocene sands.

The Ventura basin is a west-trending transverse basin containing a very thick Upper Cretaceous to Tertiary section, possibly as much as 12 to $15 \mathrm{~km}$ thick. The basin extends into the offshore and is in structural contact with the Santa Barbara Channel. All epochs from the Late Cretaceous to the Pleistocene are productive, with principal production from the $\mathrm{Mi}$ ocene and Pliocene.

The Los Angeles basin is a small, very deep basin of about $4,150 \mathrm{~km}^{2}$ with more than $10 \mathrm{~km}$ of Tertiary sediments. The late Miocene and early Pliocene sediments form the main productive horizons.

\section{Middle America Marginal-Trough Basin}

The Middle America marginal-trough basin is a large sediment trough on the Pacific continental shelf extending approximately $1,100 \mathrm{~km}$ from Costa Rica to southern Mexico. Oldest sediments are believed to be Upper Cretaceous with a maximum sedimentary section of about $8 \mathrm{~km}$. The main sedimentary fill is post-early Miocene.

The tectonic setting of the basin from the late Tertiary to the present is a forearc basin in an arc-trench gap. The outer shelf and slope is believed to be an accretionary prism, uplifted by imbricate thrusting involving oceanic crust and overlying sediments. Gravity and seismic data suggest a marginal ridge paralleling the trench. This is most likely an offshore exten- 
sion of basement of the Nicoya complex, an uplifted belt of Mesozoic and Paleogene basic volcanic, ultramafic, and associated pelagic and turbidite sediments.

The tectonic history of the Pacific marginal zone (Coast Ranges, coastal plain, shelf, slope, and trench) is relatively young, probably late Tertiary and younger. The major tectonic features of the late Tertiary are superimposed on early Tertiary and older tectoric trends. The main orogeny occurred during latest Cretaceous and early Tertiary (Laramide) with deformation and upwarping of the older arc-trench Nicoya complex. This was followed by subsidence and transgression in the early Paleogene, especially during middle Eocene with basaltic volcanism and volcaniclastic deposition. In early to middle Miocene time, folding occurred followed by marine transgression with formation of the offshore ridge and marginal-trough basin. This was accompanied by calc-alkaline plutonic activity in Costa Rica.

\section{Southeast Quadrant}

Within the Southeast Quadrant, the presence of producible hydrocarbons was detected by settlers shortly after America was discovered. In 1532, the Spanish Emperor Charles V officially authorized the settlers to produce "mineral oil" from the Caribbean island of Cubagua to be used for healing purposes. This first documented reference could be interpreted as the start of a significant oil industry in the region that was producing 3,076,000 bbl of oil and 5,562 million $\mathrm{ft}^{3}$ of natural gas per day by the end of $1987\left(489,053 \mathrm{~m}^{3} /\right.$ day of oil and 157.5 million $\mathrm{m}^{3} /$ day of gas). Brazil is not included in these figures.

The abundant oil and gas resources in the Southeast Quadrant are distributed mainly in eight countries. These are ranked based on cumulative production and remaining reserves as follows: (1) Venezuela; (2) Argentina; (3) Colombia; (4) Ecuador; (5) Trinidad-Tobago; (6) Peru; (7) Bolivia; and (8) Chile.

\section{Orinoco Oil Belt and Oriental Basin (Venezuela)}

The Venezuelan Orinoco Oil Belt, has an estimated volume of in-place heavy crude oil of 187.8 billion $^{3}$ ( 1,181 billion bbl). At year-end 1986, proved reserves in the belt were 4.16 billion $\mathrm{m}^{3}$ ( 26.17 billion $\mathrm{bbl}$ ) and unproved reserves 14.82 billion $\mathrm{m}^{3}$ (93.23 billion bbl) according to Martinez (1987).

Located on the south flank of the backarc Oriental Basin, the Orinoco Oil Belt covers an area of 54,000 $\mathrm{km}^{2}$ and consists of a prism of Tertiary sediments wedging to the south, which unconformably overlies the Cretaceous, the Paleozoic, or the Precambrian basement of the Guiana Shield. Ninety percent of the crude oil is contained in the Miocene Oficina Formation, which consists of fluvial and marine clastic rocks, and the rest is in Late Cretaceous reservoirs.

As many as 11 giant oil fields (with estimated ultimate recovery of more than 500 million bbl and 3 trillion $\mathrm{ft}^{3}$ of gas) have been discovered in the Orinoco Oil Belt. In the rest of the Oriental Basin, five other giant oil fields and two giant gas fields (El Furrial and El Placer) are presently being produced and developed.

\section{Maracaibo Basin (Venezuela)}

The sedimentary basin with the largest estimated ultimate recovery of oil and gas in the Southeast Quadrant is by far the Maracaibo Basin, Venezuela, with a total estimated ultimate recovery of 80,000 million bbl of crude oil and some 73 trillion $\mathrm{ft}^{3}$ of gas. In the Maracaibo Basin there are twelve giant oil fields with a total estimated ultimate recovery of 44,000 million $\mathrm{bbl}$ and a cumulative oil production of 27,000 million bbl by the end of 1987 .

\section{San Jorge Basin (Argentina)}

The second most important oil producing country in the Southeast Quadrant is Argentina, both for its oil reserves and present daily production. Argentina contains four giant oil fields and one giant gas field. Two of the giant oil fields are in the San Jorge Basin, where the first commercial oil field of Argentina, the Comodoro Rivadavia field, was discovered on December 13,1907, when the government was exploring for ground water for the small port and settlement there.

\section{Neuquen Basin (Argentina)}

Another giant field for both oil and gas reserves is Loma de la Lata in the Neuquen Basin of Argentina, a predominantly Jurassic and Cretaceous depositional basin filled with marine and nonmarine clastic sediment, subordinate carbonate rocks, and evaporites.

\section{Cuyo Basin (Argentina)}

The last giant oil field of Argentina is Punta de BardasVacas Muertas, within the Triassic Cuyo Basin. Cuyo is a typical pericratonic land-locked intermontane basin of a transtensional taphrogenic tectonic style. 


\section{Middle Magdalena and Llanos Basins (Colombia)}

Colombia is the third greatest oil-producing country in the Southeast Quadrant. A large part of Colombian production comes from basins where two giant oil fields have been discovered to date. One is the Middle Magdalena Basin, an intra-arc basin that lies between the two eastern branches of the Colombian Andes, as an elongated half graben with more than 12 $\mathrm{km}$ of Cretaceous to Holocene sedimentary fill. The other is the Llanos Basin, a vast grassy lowland stretching from the Andean foothills eastward to the Guiana Shield.

The main oil field in the Middle Magdalena Basin is La Cira-Infantas, a faulted anticline where producing Eocene sand unconformably overlies a deeply truncated Cretaceous sequence. Productive zones in the Eocene $\mathrm{La} \mathrm{Paz}$ Formation and in the Oligocene Mugrosa and Colorado Formations held more than $\mathbf{5 2 0}$ million bbl of oil of which some 459 million bbl had been produced by 1987 .

Los Llanos Basin is a Paleozoic through Tertiary clastic sedimentary basin in the sub-Andean pericratonic trend. Very asymmetric, the main pronounced structural development is in the foothills belt, where compressional stresses associated with the Andean Orogeny created a series of large folds and westward-dipping thrust faults.

Exploration of the Llanos Basin has been cyclic. The first well drilled in 1944 resulted in a subcommercial discovery. Increased exploration efforts took place in 1958, 1969, and finally in 1980, when the Arauca field was discovered. Exploration was resumed in 1983 and is continuing at a good pace after discovery of the Cano Limon X-2, which tested oil from the late Eocene Mirador Formation at a rate of 10,690 bbl/day of low-sulfur, 31 degrees American Petroleum Institute (API) gravity oil. Subsequent drilling has established the discovery as a giant oil field, with an estimated ultimate oil recovery of over one billion bbls. Present oil production of the Cano Limon area is 209,000 bbl per day.

\section{Oriente Basin (Ecuador)}

The most prolific basin in Ecuador is the Oriente Basin, extending from the foothills of the Andes eastward over an area of over more than $100,000 \mathrm{~km}^{2}$. Oil accumulations are structurally controlled mainly in north-trending faulted anticlines, but stratigraphic trapping is also evident in certain areas.

Two giant oil fields were discovered in the Oriente Basin in 1969: Shushufindi and Sacha. The anticlinal features are of very low structural relief, with lengths of $35 \mathrm{~km}$ and $28 \mathrm{~km}$, respectively. Commercial production is from the $U$ and $T$ sands of the Napo Formation in the Shushufindi field (estimated ultimate recovery of 1.35 billion bbl and from the Hollin Formation (69 percent) and the $U$ sands of the Napo Formation (21 percent) in the Sacha field (estimated ultimate recovery of 753 million bbl).

\section{Progreso Basin (Equador)}

This marginal basin, which extends from the Gulf of Guayaquil to the northwestern part of Peru, contains as much as $8 \mathrm{~km}$ of post-Oligocene shale, siltstone, and sandstone. The sedimentary section is mostly Miocene, with some Pliocene and Pleistocene marine deposits. In 1970 the giant Amistad gas field was discovered in the Gulf of Guayaquil. The estimated ultimate recovery of the Amistad undeveloped field is 3 trillion $\mathrm{ft}^{3}$ of natural gas.

Talara Basin (Peru)

The Talara or Northwestern Peruvian Basin lies on the Pacific coast west of the Andes. Only a part of the basin is preserved on land, but it extends well into the offshore area where it may connect with other Tertiary basins along the Pacific coast of South America (Progreso, Daule, and Sechura). The basin contains more than $8 \mathrm{~km}$ of Campanian (83-73 Ma) to late Eocene marine to fluvial-transitional clastic sediment. The main producing horizon is the early Eocene Parinas Formation consisting of deltaic, fluvial, and turbidite deposits. Production is also obtained in descending order of importance from the Paleocene Salina-Mogollon Formation and from the middle and late Eocene Talara and Verdum Formations. Finally, oil was produced from the Oligocene and Miocene in the depleted Zorritos oil field in the Progreso Basin, close to the Ecuadorian border.

A giant field, the La Brea-Parinas field discovered in 1869 , has produced for more than a century with a cumulative production of 539 million bbl of oil. As of December 31,1987 , the estimated ultimate recovery is 592 million bbl. For the entire Talara region the estimated ultimate recovery is 1,339 million bbl of crude oil.

\section{Ucayali Basin (Peru)}

The lower Ucayali Basin, of the pericratonic domain, extends into the central part of Peru, near the Urubamba River valley. In this basin a sedimentary fill as thick as $5.5 \mathrm{~km}$ composed of Paleozoic, Jurassic, Cretaceous, and 
Tertiary deposits overlies the Precambrian Andean basement. Two giant gas fields, San Martin and Cashiriari, have estimated ultimate recoveries of 3 trillion and 8 triilion $\mathrm{ft}^{3}$ of natural gas, respectively. Production from these huge anticlines is from Cretaceous sandstone reservoirs at depths between $3,900 \mathrm{~m}(12,800 \mathrm{ft})$ in the San Martin field and $2,440 \mathrm{~m}(8,000 \mathrm{ft})$ in the Cashiriari field.

\section{Trinidad-Tobago Basins}

The main structural elements of the Trinidad-Tobago Basins in the easternmost part of the Venezuelan mobile belt are lateral extensions of tectonic features farther west. These elements from north to south are the Northern Range (Coastal Range of Venezuela), El Pilar fault, Northern Basin, Central Range, Naparima thrust belt, the prolific Southern Basin, and the Southern Range.

Several giant and major oil and gas fields were discovered in the Trinidad-Tobago Basins, starting in 1913 with the Fyzabad Group (estimated ultimate recovery of 850 million bbl) on land, followed by Soldado field (estimated ultimate recovery of 600 million bbl) offshore in the Gulf of Paria. Many other oil fields lie on the island, such as Point Fortin, Erin, Palo Seco, Penal, Oropuche, Trinity, Catshill, Moruga, Balata, Morne Diablo, Navette, and others. The Miocene Cruse and Forest-Moruga Sandstones are the main oil reservoirs. The most common trapping mechanisms are up-dip permeability pinchouts over or on the flanks of contemporaneous mud diapirs. Oils have an average gravity of 23 degrees API.

At present active exploration is confined to the offshore area, both in the West Tobago Basin in the north and in the Columbus-Galeota Basin in the south and east. Significant discoveries have been made, mainly natural gas, like the giant North Coast Group (estimated ultimate recovery of 3 trillion $\mathrm{ft}^{3}$ ) and the Galeota Group (7 trillion $\mathrm{ft}^{3}$ of recoverable natural gas). Productive intervals are mainly of Pliocene age (Gros Morne and Saint Hilaire Formations), and even Pleistocene, such as the Queen's Beach and East Manzanilla gas fields, in the tropical Atlantic Ocean.

\section{Northwest Quadrant}

\section{Sedimentary Basins in the Northwest Quadrant}

Figure 12 shows about 197 sedimentary basins in this map area (listed in table 8). Stratigraphic columnar sections are shown for the representative 47 sedimentary basins and 1 oceanic rise (fig. 17). In this map, a sedimentary province, which has the undeformed sediments with thickness of more than $1000 \mathrm{~m}$, is identified as 'a sedimentary basin'. Almost all sedimentary basin boundaries coincide with the $1000-\mathrm{m}$ isopach line, or main tectonic lines, which control the tectonic development of the basins. Most oil and gas fields are located within sedimentary basins. Many coal fields, however, tend to be located outside of the sedimentary basins.

The 197 main sedimentary basins of the Northwest Quadrant can be classified as 12 types according to their geographic distribution and geologic characteristics, as follows:

1. Arctic Sea, northern area of the North American Continent and Asian Continents

2. Pacific coast of the North American Continent

3. Along the Aleutian Islands arc, between the Pacific and North American Plates

4. Over the cratons of Asian Continent

5. Along the suture zone between the cratonic blocks within the Asian Continent

6. Along the eastern margin of the East Asian Continent

7. In and along the trench-island arc-marginal sea systems of the Northwest Pacific Ocean

8. Along the continental margin of the Southeast Asian Continent including the Sunda Shelf

9. Inside the Sunda Shelf-Indochina region tectonically controlled by Cenozoic wrench tectonics related to the collision of the Australia-India Plate to the Eurasia Plate

10. Along the islands around the Banda Sea

11. In and around New Guinea

12. Along the Solomon islands arc

Each basin within a geographic group has common geologic characteristics, such as initiation age, lithofacies variation, and tectonic development. This implies that the generation and evolution of sedimentary basins has been strongly affected by the regional geologic evolution or by the movement of the multiple plates. From the view point of petroleum geology, these geological characteristics effect the basic characteristics of the oil and gas fields, source rock, reservoir facies, thermal and diagenetic histories, and oil and gas potential.

The sedimentary basins of type 4 distributed over the cratons of the Asian Continent, for example, Eerdosi Basin (074, fig. 13 and table 8) and Shichuan Basin (085, fig. 13 and table 8), have the following general characteristics:

1. Developed in a non-marine environment

2. Basin initiation in the Precambrian or early Paleozoic

3. Basins with round or square shapes, and diameter of several hundred kilometers

4. Giant oil and gas fields present

The sedimentary basins of type 6, distributed along the east margin of the east Asian Continent, Songliao Ba- 
$\sin (065$, figure 13 and table 8 ) and East China Sea Basin (081, fig. 13 and table 8), for example, have the following general characteristics:

1. Initiated in a nonmarine environment, and developed in a non-marine environment or shallow marine environment

2. Basin initiation in the Mesozoic

3. Basins elongated in a direction parallel to the trench system

4. Development of these basins affected by rift tectonism related to the Pacific Plate subduction beneath the Eurasia Plate

5. Giant oil and gas fields present

The sedimentary basins of type 7 can be divided from their geographic position in the trench-island arc-marginal sea systems into forearc basins, backarc basins, and intra-arc basins and are distributed in and along the trench-island arc-marginal sea systems of the northwest Pacific Ocean. Niigata-Akita Basin (048, fig. 13 and table 8), Shimajiri Basin (061, fig.12 and table 8), and Visayan Sea Basin (126, fig. 12 and table 8), for example, have the following general characteristics:

1. Initiated in a nonmarine environment; almost all initiated and developed in a marine environment

2. Significant variations of lithofacies and depositional environments in the lateral and vertical dimension

3. Basin initiation in the Cenozoic

4. Basins elongated in a direction parallel to the island arc

5. Giant oil and gas fields not present

\section{Oil and Natural Gas}

Index maps and data of selected oil and gas fields for the Northwest Quadrant are shown in figs. 13 and 14. Data such as the year of discovery, reservoir age, lithology for each field, and cumulative production are included in table 9.

\section{Southwest Quadrant}

The major oil and gas fields of the map sheet area have been plotted on the main map and are shown in fig. 15 and are detailed in table 11 . The estimated proven reserves of oil and gas (1992 figures) of producing countries within the map sheet area are shown in table 12. Economic oil and gas deposits in the non-overlap region of the map are confined to Papua New Guinea, Australia, and New Zealand. The estimated proven reserves of these three countries are: oil-1,893,930 (1,000 bbl) and gas-26,506 (bcf) (table 13).

\section{OIL SAND}

Oil sand is defined as those oil-impregnated sands from which the oil cannot be recovered by conventional borehole methods. The gravity of the oil is generally about 10 degrees API or less. Significant oil-sand deposits are shown by a green stippled pattern on the map. Major deposits of oil sand occur in Canada and Venezuela; minor deposits occur in Trinidad, Columbia, and the United States (Utah, California, and New Mexico).

\section{Northeast Quadrant}

Four major oil-sand deposits covering an area of approximately 49,500 km2 occur in central Alberta, Canada: Athabasca, Wabasca, Peace River, and Cold Lake. The deposits occur in a wedge of Cretaceous sediment that onlaps the Canadian Shield. The depth ranges from the surface down to $600 \mathrm{~m}$. About $2000 \mathrm{~km}^{2}$ of these deposits are covered with $50 \mathrm{~m}$ or less of overburden. Oil-in-place in the four deposits is estimated to be 1,080 billion barrels, of which 35 billion barrels are considered economically recoverable by current methods of open-pit mining. Currently the only in situ production of synthetic crude oil from oil sands is from the central Alberta deposits (fig.16).

\section{Southeast Quadrant}

Giant deposits of oil sand occur in Venezuela, and minor deposits are found in Colombia, Trinidad, Ecuador, and Peru.

The largest accumulation in the Southeast Quadrant is the Miocene oil sand of the formerly named Orinoco Tar Belt. Oil-sand deposits are base-wedge and wedgeedge occurrences where Tertiary deposits onlap the Precambrian basement of the Guiana Shield.

Smaller but important oil-sand deposits have been reported in Colombia and Ecuador; the main one is located west of the Sacha giant oil field, close to the Andean foothills. Another significant oil-sand deposit is in southern Peru, in the mountainous area close to the headwaters of the Indio Muerto and Yauca Rivers.

The two major oil-sand areas of Canada and Venezuela are shown in fig. 16 with generalized structure sections that show the similar tectonic setting of the two deposits.

\section{OIL SHALE}

Oil shales are fine-grained sedimentary rocks which when heated in a closed retort, yield substantial amounts 
of oil (40 liters of oil per tonne of shale is considered the minimum yield for a true oil shale). The organic matter contained in oil shales is usually derived from algal remains and from spores and pollen that have been deposited in swamps, lakes, and shallow seas. Oil shale is depicted on the map by a green outlined pattern.

The most significant oil-shale resources of the $\mathrm{Pa}$ cific Basin occur in the Northeast Quadrant in Colorado, Utah, and Wyoming, of the western United States.

In the Southeast Quadrant only a few minor oilshale deposits have been reported in Chile and Argentina.

In the Northwest Quadrant large marine oil-shale deposits of Early and Middle Cambrian age occur on the northeastern Siberian Platform around Anabar, Olenek, and the Lena Rivers. Oil-shale deposits of Jurassic and Cretaceous age in northern China and Mongolia are mostly associated with coal-bearing rocks. Oil-shale deposits of Tertiary age in China, Thailand, and Myanmar (Burma) are associated with coal-bearing rocks and occur in marginal regions where major orogenic movements produced folded and faulted mountains (Duncan and Swanson, 1965; Duncan, 1976).

In the Southwest Quadrant oil shales are found in all states of Australia and in New Zealand. Most of Australia's demonstrated oil-shale resources are situated in narrow deep Tertiary basins along the central coast of Queensland. However, far larger are the inferred deposits in a thin but extensive marine Cretaceous formation underlying much of northwestern Queensland, which is estimated to contain 3,838,000 million tonnes of shale containing 230,000 million cubic meters of oil (tables 18 and 19). At present Australia's oil-shale resources are classed as subeconomic.

\section{COAL}

Coal deposits of the Pacific Basin are shown in brown patterns indicating rank and general areal extent of the deposits.

The classification of coals by rank is based on the percentage of fixed carbon and calorific value (expressed in BTUs per pound) calculated on a mineralmatter-free basis. Although there may be some differences between countries, in general the rank classification used is that established by the American Society for Testing and Materials (1966). This is summarized in appendix IV.

Major coal deposits occur throughout much of the Pacific Basin. Most of the significant deposits and pro- duction are associated with interior basins and bordering foreland-thrust belts.

Coal production for the countries of the Circum-Pacific region for 1996 is shown in table 3.

\section{Northeast Quadrant}

Major coal deposits occur throughout much of the Northeast Quadrant (fig 18; table 14). Most of the significant deposits and production are associated with interior basins and bordering foreland-thrust belts. Significant coal deposits of the Pacific margin, with only minor production at present, occur in the Cook Inlet and Susitna basin areas of Alaska, the Queen Charlotte Islands, and Vancouver Island of the Canadian margin, Washington, Oregon, California, Mexico, and Costa Rica.

The major producible coal deposits of western Canada occur in the synorogenic clastic wedge of eastern British Columbia and Alberta. The coal ranges in age from latest Jurassic to Paleocene. The Energy Resources Conservation Board (1985) estimates remaining in-place resources of all types of coal in Alberta at 59 gigatonnes (109) as of December 31, 1984, of which 22 gigatonnes are considered recoverable.

The only producing coal field in central Alaska is in the Nenana basin. Production from this area totalled 800 million short tons in 1984. The major coal-producing areas of the western United States are the Great Plains and Rocky Mountain province. Production from these two areas in 1984 totalled 248.9 million short tons.

Coal deposits of Mexico occur in three basins: (1) in the state of Coahuila (north-central Mexico) with six coal districts, (a) Rio Escondido, (b) Sabinas, (c) Esperanza, (d) Saltillito, (e) San Patricicio, and (f) Monclova; (2) east of Hermosillo, Sonora; and (3) in the state of Oaxaca, southeast Mexico.

One of the more important deposits in Central America is the Rio Uscari district in Costa Rica.

\section{Southeast Quadrant}

Commercial coal deposits ranging in rank from anthracite to lignite and peat occur within the area covered by the Southeast Quadrant (fig. 19, 20; table 15). Commercial deposits are of late Paleozoic, Triassic, Jurassic, Cretaceous, and Tertiary age. Peat deposits are mainly of Quaternary age.

Rough estimates for principal coal deposits in the Southeast Quadrant total 46.6 billion metric tons of proved and additional reserves. The reported commercial peat deposits are on the order of 208 million metric tons.

The largest coal resources, about 20 billion metric tons, are found in Colombia, followed by Venezuela and Chile, 
with 9.2 and 8.7 billion metric tons, respectively. Colombia is by far the largest coal producer with an output of close to 15 million metric tons per year (table 15). Coal is found in early Tertiary basins in intermontane valleys along the flanks and foothills of the Andean and Caribbean Ranges and along their northern and eastern extensions. Eighty percent of these coal reserves are in the Cundinamarca and Boyaca Provinces, El Cerrejon being one of the most important deposits with estimated reserves of over 1,600 million metric tons. The area of this Paleocene deposit is 38,000 hectares at $200 \mathrm{~m}$ below the surface. The present El Cerrejon project, at a cost of 3 billion dollars, will have a production rate of 15 million metric tons per year.

Early Tertiary Colombian and Venezuelan coal is mainly bituminous. Early Cretaceous coal of Peru is anthracitic, and Tertiary coal of Chile and Argentina is subbituminous and lignitic. Quaternary peat deposits are reported in Argentina, Bolivia, and Ecuador.

\section{Northwest Quadrant}

The economically workable coal seams occur in intracratonic basins and platforms, and orogenic regions, of Upper Carboniferous-Permian, Upper Triassic-Jurassic, and Upper Cretaceous-Middle Tertiary age (fig. 21; table 16).

In the orogenic regions like collisional suture, island arc, and so on, coal-bearing basins may have been exposed to rapid differential uplift and subsidence, and as a result, the basins tend to be limited both in extent and coal property. Coal-bearing formations are likely to be deeply buried, often in areas of high geothermal gradient due to regional and local volcanic activity. This causes relatively high but variable character in the rank of coal.

In the stable cratonic regions, relatively extensive deltaic coal-bearing basins are usually formed. Usually transgression and regression extend over wide areas and then laterally persistent coal seams are formed in coastal environments. Such areas seldom suffer intense deformation. Therefore, range in the rank of coal is often relatively narrow, and there is no definite structural control on coal-bearing basins.

This quadrant area is basically composed of the Angaraian paleoplate, Cathaysian paleoplate, and fragments of Gondowanaland from north to south. The Cathaysian paleoplate contains the Bureya, Tarim, SinoKorean and Yangtze cratons.

The suture between the Siberia and Tarim-Breya cratons was the main ocean separating the Angaraian paleoplate and the Cathaysian paleoplate during Paleozoic and Early Mesozoic time. The collisional suture separating the Bureya and Sino-Korean cratons is of Permo-Triassic age. The collisional suture separating the
Sino-Korean and South Yangtze craton is of Late Triassic-Early Jurassic age. The next collisional suture to the south, separating the Yangtze craton from North TibetMalaysia, and from Indonesia, is of Jurassic age. The continuous area from Northern Tibet through Malaysia and Indonesia is considered as a separate plate further extending under the Gulf of Thailand to southwest Borneo.

By Late Triassic, the core of Southeast Asia was largely consolidated. Thereafter, the additional Gondowanaland fragments of South Tibet and of BurmaNorthwest Sumatra were accreted during Cretaceous time. Finally, India arrived and during Eocene time, collided and drove into the pre-existing mosaic of plates in southern Asia.

In Angararian paleoplate, there are developed extensive deltaic coal-bearing strata of Carboniferous, Permian, Lower and Middle Jurassic, Upper Cretaceous and Neogene age. In the Sino-Korean and Yangtze cratons, extensive deltaic coal-bearing strata from Middle Carboniferous to Lower Permian in age and Jurassic coals are well developed in Korea. In the collisional suture separating the Tarim-Sino-Korean cratons and Yangtze craton, Jurassic and Cretaceous coals are well developed.

In Vietnam, the Permian to Triassic basins that occupy a collisional suture zone are interpreted as basins that have subsequently opened as a result of wrench faulting. They are commonly characterized by rhyolitic volcanism and by the presence of important coal deposits. A major orogenic event in the Late Cretaceous was the collision of the Burma microplate with the Sinoburmalaya margin of Eurasia, and this collision was the major cause of formation of coal-bearing basins. In early Tertiary, the Burma microplate was moving northwards and important transform motion began in Thailand, Malaya Peninsula, and Sumatra. Slight extension on strike-slip faults led to important Tertiary graben-like coal basins along and adjacent to the line of these faults. In eastern Kalimantan, extensive deltaic coal-bearing strata are developed in the continental marginal basins. In the Taiwan region and Japan, the Pacific Plate convergence caused strike-slip faulting or differential uplift and subsidence and the resulting formation of coal-bearing basins.

The collision between the Indian Plate and the Eurasian Plate and the subduction of the Pacific Plate under the Eurasian Plate in Eocene time led to the formation. coal basins caused by intracratonic strike-slip fault movement in China, Burma, and Thailand, and also the volcanic inner-arc intramontane coal basins in Japan, Taiwan, and the Philippines (Tapponnier and Molnar, 1977; Tatsch, 1980; Zhang and others, 1984; Parker and Gealey, 1985; Taira and Tashiro, 1987; Hutchson, 1989). 


\section{Southwest Quadrant}

Irian Jaya

Coal seams up to $1 \mathrm{~m}$ in thickness occur in nonmarine fluviodeltaic sediments of Permian age in the center of the "Birds Head" region of western Irian Jaya. Rocks of similar age and provenance that crop out along the western end of the Central Range in eastern Irian Jaya also contain thin coal seams up to $1.5 \mathrm{~m}$ thick (table 17).

A number of minor deposits of lignite are known from the Salawati and Bintuni Basins in the "Birds Head" region and from the Akimegah, Iwur, and North Coast Basins of eastern Irian Jaya. These are of Neogene age. All of the coal occurrences located to date in Irian Jaya are either too small, too low grade, or too remote to be economic.

\section{Papua New Guinea}

Apart from coal bands found in Jurassic sediments in oil exploration wells in the Gulf of Papua, all Papua New Guinea coal is Neogene or Quaternary in age. Neogene coal deposits occur throughout the country; however, the major occurrences are:

1. A belt extending from around the Gulf of Papua through the Southern Highlands westward to the Star Mountains on the Irian Jaya border

2. The North Sepik region

3. The Huon Peninsula

4. The Gazelle Peninsula on the eastern tip of New Britain and southern New Ireland

5. Cape Vogel Basin.

6. Areas around Goroka and Gumini in the Highlands region.

Quaternary coals are found interspersed with those of Neogene age in the Gulf region, Southern and Western Highlands, and North Sepik area.

In general the coal seams tend to be thin, discontinuous, and are often dipping and located in inaccessible localities. Analyses show that (1) the rank of the coals varies between lignite and subbituminous; (2) there are wide variations in composition within individual deposits; (3) in general the coals have a high sulfur content; and (4) the Quaternary coal shows very high ash and low fixed-carbon content.

None of the coal deposits are considered economic.

New Caledonia

Small deposits of coal occur in a number of Jurassic to Cretaceous basins that are found along the western side of the island. In general the individual seams are discontinuous and vary greatly in thickness. Rank ranges from subbituminous to bituminous. The largest basin (Nondoue) lies between Noumea and St. Vincent to the northwest; here, however, the coal seams are extremely variable in extent and are not economic. The Moindou Basin farther to the northwest contains seams up to $2 \mathrm{~m}$ in thickness and small quantities of coal have been mined in the past (1881-1902, 1930-1933) to fire nickel furnaces near Noumea.

\section{New Zealand}

New Zealand coal ranges in age from Cretaceous to Tertiary and in rank from lignite to bituminous. Approximately 86 percent of the estimated total recoverable coal reserves of 6,500 million tonnes is lignite, 11 percent subbituminous, and 3 percent bituminous. The coal fields can be grouped into seven regions. They are (north to south): Northland, Waikato, Tarañaki, Nelson-Westland, Canterbury, Otago, and Southland.

\section{Australia}

Australia has about six percent of the world's demonstrated resources of black coal and eight percent of the world's brown coal. It is the world's leading exporter of black coal. The bulk of the very large resources of Australian coal are Permian or Tertiary in age with lesser Triassic, Jurassic, and Cretaceous deposits. In contrast to Europe only minor occurrences of Carboniferous coal are known. Coal grades range from lignite to bituminous and minor amounts of anthracite. Coal is mined in all of the Australian States except the Northern Territory with the bulk of the estimated recoverable resources in Queensland and New South Wales (Permian, bituminous) and Victoria (Tertiary, lignite).

\section{Antarctia}

Laminae and lenses of coal occur in Permian sandstone at Horn Bluff in George V Land in East Antarctica. The quantity of coal is insignificant and is of no economic importance.

\section{GEOTHERMAL RESOURCES}

Three kinds of geothermal data are shown on the Energy-Resources Map of the Pacific Basin: geothermal fields that have been identified, those developed to generate electricity, and hot springs with surface temperatures $>50$ degrees $\mathrm{C}$.

The classification scheme, showing type of hydrothermal-convection system (water-dominated or vapor-domi- 
nated) and estimated reservoir temperature, is from Muffler (1978). Hydrothermal-convection systems have been further divided to distinguish between systems that are generating power and those that are currently being developed.

\section{Northeast Quadrant}

The largest producer of electricity from geothermal energy in the Northeast Quadrant is The Geysers geothermal plant, located in the Coast Ranges in northern California. The system is vapor-dominated, one of three of this type in the United States. The plant currently has a generating capacity of 1,792 megawatts (MW) (DiPippo, 1985).

Several hydrothermal-convection systems have been identified throughout northern California, Oregon, and Washington in the volcanic Cascade Range, and in the volcanic area of central and southeastern Oregon. The hydrothermal-convection system at Mt. Lassen in northern California is a high-temperature, vapor-dominated system, but because of National Park status it has not been developed. None of the identified systems in the Cascades or southeastern Oregon have been developed to date, but in many of these areas geothermal water is being utilized for space heating.

Young volcanoes exist throughout the Snake River Plain of Idaho, and numerous hydrothermal-convection systems have been identified. The size of the reservoirs, however, is not known. Farther east, in northwestern Wyoming, a third vapor-dominated system occurs in the Mud Volcano area of Yellowstone National Park, but it is also withdrawn from commercial development because of National Park status.

In the region of the eastern Sierra Nevada range front in eastern California and western Nevada, the Long Valley caldera is related to the young volcanic features (DiPippo, 1985). The Coso $25 \mathrm{MW}$ geothermal plant was constructed in 1985.

The occurrence of hot-water reservoirs in the Imperial Valley of southern California is attributed to active crustal spreading and Quaternary volcanism. Three geothermal plants have been built in this region and are generating electricity: Salton Sea (10 MW), Brawley (10 MW), and East Mesa (12.5 MW). A fourth plant, at Heber, has a generating capacity of $45 \mathrm{MW}$. In the southern part of this region, the Cerro Prieto geothermal plant in northern Baja California produces 400 MW (DiPippo, 1985).

In the Basin and Range geologic province, hydrothermal-convection systems in the northwest part of Nevada are the result of crustal extension. The Brady Hot Springs and Desert Peak geothermal fields in northwestern Nevada were being developed in 1985 (DiPippo, 1985).
A small cluster of hydrothermal-convection systems are found in southwestern New Mexico and southeastern Arizona and to the north near the Wasatch front in Utah. The Roosevelt (Utah) geothermal plant produces $20 \mathrm{MW}$, and the Fort Cove-Sulphurdale (Utah) geothermal plant produces $0.675 \mathrm{MW}$ in each of its four units.

In the northern Rockies, hydrothermal-convection systems occur mainly in the region of the Idaho batholith in southwestern Montana. Other small systems occur in the Rocky Mountains, but they are scattered, and temperatures are lower than $90^{\circ} \mathrm{C}$.

The easternmost extent of geothermal fields in the western United States is the Rio Grande rift, which extends from New Mexico northward into the southern Rockies of Colorado. The largest identified hot-water system of this geologic province occurs within the Valles caldera in New Mexico.

In Alaska, twenty-five hot-water hydrothermal-convection systems with temperatures from $90^{\circ}$ to $150^{\circ} \mathrm{C}$ and three with temperatures $>150^{\circ} \mathrm{C}$, have been identified. They occur across central Alaska and in southeast Alaska. Because of the remoteness of these geothermal fields, none are being commercially developed at this time.

On Hawaii, the youngest of the Hawaiian Islands, a small geothermal power plant, Puna No. 1, was built on the rift zone of Kilauea volcano. The plant, built in 1982, generates $5 \mathrm{MW}$.

Canada's high-temperature geothermal areas are located along the volcanic belts of the Cordillera (Jessop, 1985). Two identified geothermal fields, Mt. Meager area at lat $52.5^{\circ} \mathrm{N}$, long $123.5^{\circ} \mathrm{W}$, and Mt. Cayley at lat $50^{\circ} \mathrm{N}$, long $123.5^{\circ} \mathrm{W}$. have reservoir temperatures that exceed $150^{\circ} \mathrm{C}$. Because the need for electrical power in Canada has been declining, however, the pace of development of these geothermal fields has slowed. Some of the lower temperature $\left(<90^{\circ} \mathrm{C}\right)$ geothermal areas of the sedimentary aquifers of the prairies in Canada are presently being utilized for direct-heat uses.

Mexico has developed two geothermal fields: Cerro Prieto in Baja California, and Los Azufres (lat $20^{\circ} \mathrm{N}$, long $100.5^{\circ} \mathrm{W}$ ); a third field is under development at Los Humeros (lat $19.5^{\circ} \mathrm{N}$, long $97.5^{\circ} \mathrm{W}$ ). Both Los Azufres and Los Humeros occur in areas of Holocene volcanics. The plant at Los Azufres currently generates $25 \mathrm{MW}$, and Los Humeros developed in 1985 was have a generating capacity of $15 \mathrm{MW}$. (DiPippo, 1985).

The chain of volcanoes in western Central America is an area of high potential for geothermal energy. El Salvador has developed the Ahuachapan geothermal field. The power plant currently produces $95 \mathrm{MW}$ and is the first geothermal plant built in Central America. Guatemala is planning to install a $15 \mathrm{MW}$ plant at 
Zunil. Many areas in Guatemala look promising, but further exploration is needed. Nicaragua developed a $35 \mathrm{MW}$ plant on the southern flank of Momotombo volcano at Lake Managua. Costa Rica was developing the Miravalles geothermal field in 1985 (Corrales, 1985 projected to be online in 1990 with a power potential of $32 \mathrm{MW}$, with a planned additional $50 \mathrm{MW}$ plant (DiPippo, 1985). In Panama, in 1985 there were seven areas identified as geothermal localities, and regional assessments were under way (Ramirez, 1985).

\section{Southeast Quadrant}

Practically all of the geothermal areas considered are distributed in the calc-alkalic Pliocene to Quaternary volcanic rocks that stretch along the Andes.

The first geothermal power plant installed in South America is in the Copahue geothermal volcanic field in central-western Argentina, in the Andean foothills. This small 670-kilowatt plant began operating in early 1988. Also in Neuquen Province the Domuyo Volcano, with abundant hot springs, fumaroles, and geysers, is being studied because of its very high potential for geothermal energy. There are several other areas in Argentina where geothermal potential has been assessed including Taco-Ralo-Rio Hondo (Santiago del Estero Province) and Tuzgle Volcano (Salta Province). In Northern Chile, potential geothermal developments are being studied at El Tatio, Puchuldiza, and Suriri. The estimated power potential for the El Tatio site is $100 \mathrm{MW}$ and for the Suriri site is $50 \mathrm{MW}$. In Colombia, the Ruiz and Chiles Volcanoes, Azufral de Tuquerres, and Paipa are areas of potential development. Five areas are being assessed in Ecuador: Cuenca-Azogues, Chimborazo, Chadupas, ImbaburaCayambe, and Tufino-Chiles-Cerro Negro. Six regions of Peru may have potential of geothermal development: the Southern Volcanic Chain, the Puno region, the Huancavelica-Huancayo region, the Central region (Cajatambo-Cerro de Pasco), the Ancash region, and the Cajamarca region. In Venezuela two promising geothermal sites have been identified: Barcelona-Cumana and Pilar-Casanay. The hot springs of Pomarapa Volcano and the Pulacayo area in Bolivia indicate potential geothermal resources there, but further exploration is needed to evaluate the level of potential (table 20).

\section{Northwest Quadrant}

Hot-spring data for Japan are so numerous that only those springs with a surface temperature greater than $90^{\circ} \mathrm{C}$ are shown on the map, with each circle repre- senting a group of hot springs. For areas outside of Japan, data were collected from various published sources. Data for Thailand is from the Geological Survey of Japan (1987), and data for the Philippines are based on Alcaraz (1974). Hot-spring data for other Southeast Asian countries are from Waring (1965) and Gupta (1980).

\section{Japan}

In Asia geothermal power generation was introduced earliest in Japan, but development in the 1970s and 1980 s was very slow, mainly due to environmental concerns. As of 1990, the total installed capacity amounts to $283 \mathrm{MW}$, composed of eight large plants and two small plants for local use at hotels. Throughout Japan, exploration and resource assessment for newly surveyed high-temperature geothermal reservoirs have been and are now very active. By 1995 at least three more geothermal power plants will be on line in northeastern Japan and Kyushu. A great variety of opinion exists on the geologic control of the distribution of geothermal resources on the Japanese Islands, and it has been recently reviewed by Kimbara (1988).

\section{The Philippines}

The Philippines is the largest producer of geothermal power in Asia, and second largest in the world, with a total installed geothermal power generation capacity as high as $894 \mathrm{MW}$ for four geothermal fields: Mak-Ban on Laguna; Tiwi on Luzon; Tongonan on Leyte; and Palimpinon on southern Negros. Besides these four sites, exploration is in progress in six prospective areas on Luzon, three on Visayan, and one on eastern Mindanao with total capacity $1554 \mathrm{MW}$ (Datuin and Troncales, 1986). Geographically, these geothermal areas are associated with three major belts of Pliocene to Quaternary volcanoes of the Philippine Island Arc: the western volcanic belt faces the South China Sea and includes geothermal resource areas of northern and central Luzon and Mindoro Island; the eastern volcanic front facing the Pacific parallel to the Philippine Fault, including the very active geothermal fields of southern Luzon, Leyte, and Mindanao; and the volcanic belt aligned through Sulu Archipelago and toward its northeastern extension.

\section{Thailand}

On the basis of cooperative surveys by several national and international institutes, two geothermal resource areas have been selected for intensive assessment: the San Kampaeng area and the Fang area in the north- 
western part of Thailand. A 300-kilowatt binary-cycle pilot plant is being built in the Fang area using geothermal fluids at $150-200^{\circ} \mathrm{C}$. Geothermal fields of northern Thailand are located at the easternmost tip of the Himalayan Orogenic Belt.

\section{Indonesia}

According to a nationwide assessment of geothermal resources in Indonesia by Alzwar (1986), total resource potential is estimated to be $13,000-14,000 \mathrm{MW}$ which comprises 3,550 MW for Java, 4,900 MW for Sumatra, 3,000 MW for Sulawesi, and other islands. However, installed capacity at present is only $140 \mathrm{MW}$ at Kamojang and $2 \mathrm{MW}$ at Dieng, on Java. The Darajat geothermal field, located 10 $\mathrm{km}$ southwest of Kamojang, and the Salak geothermal field, also in Java, are now under final tests for development at the $110 \mathrm{MW}$ level. The Lagendong field in the northern part of Sulawesi is expected to produce 15 MW by 1993. The distribution of potential geothermal resource areas is clearly controlled by the prominent trend of volcanic zones that parallel active trenches, such as the volcanic zones of Sumatra, Sunda Strait, Java, Bali, and Nusatenggara, corresponding to the Sunda Trench and the volcanic region of Halmahera and Sulawesi, also caused by strong interaction between adjacent plates.

\section{Southwest Quadrant}

Geothermal activity is characteristic of the volcanic island-arc systems bordering Australia to the north and east; however, few of these resources have been utilized to date. Most numerous are water-driven systems that are usually associated with waning volcanic activity or deepseated faulting. Surface expressions of these systems include warm to boiling springs and, in volcanic areas, solfataric activity. Some geothermal fields are vapor driven and are associated with active volcanism. Strong fumarolic activity is often the surface expression of these latter systems. Hot springs that are found away from active plate margins (for example, in the Australian continent) are formed by deeply circulated water in sedimentary basins.

\section{New Zealand}

The only area in the Southwest Pacific in which geothermal resources are utilized on a commercial basis is in and around the Taupo volcanic region of the North Island of New Zealand. Here, 12 geothermal fields are known. Both water and vapor systems occur. The total installed capacity of the generators is $284 \mathrm{MW}$. 


\section{REFERENCES CITED AND ADDITIONAL SOURCES OF DATA}

\section{NORTHEAST QUADRANT}

Acevedo, J.S., 1980, Giant fields of the southern zoneMexico, in M.T. Halbouty, ed., Giant oil and gas fields of the decade 1968-1978: American Association of Petroleum Geologists Memoir 30, P. 339-385.

Alcantara, J., and 0. Castillo, 1982, Project focus on Venezuelan heavy oil: Oil and Gas Journal, v. 80 , no. 22 , p. 117 125.

American Association of Petroleum Geologists, 1972-1985, Foreign developments issues: American Association of Petroleum Geologists Bulletin, v. 56-69.

American Petroleum Institute, American Gas Association, and Canadian Petroleum Association, 1980, Reserves of crude oil, natural gas liquids, and natural gas in the United States and Canada as of December 31, 1979, v. 34: New York, American Petroleum Institute, 253 pp.

American Society for Testing and Materials, 1983, Annual book of ASTM standards, v. 05.05, gaseous fuels; Coal and coke: Philadelphia, American Society for Testing and Materials, $531 \mathrm{pp}$.

Armentrout, J.H., and D.H; Sueb, 1985, Hydrocarbon exploration in western Oregon and Washington: American Association of Petroleum Geologists Bulletin, v. 69, p. 627643.

Avila, F.C., and others, 1984, Recent studies of basins are encouraging for future exploration in Honduras: Oil and Gas Journal, v. 82, no. 38, p. 139-149.

Bane, S.C., and R.R. Champony, 1980, Geology and development of the Teak oil field, Trinidad, West Indies, in M.T. Halbouty, ed., Giant oil and gas fields of the decade 19681978: American Association of Petroleum Geologists Memoir 30, p. 387-398.

Barr, K.W., S.T. Waite, and C.C. Wilson, 1958, The mode of oil occurrence in the Miocene of southern Trinidad, British West Indies, in L.G. Weeks, ed., Habitat of oil: Tulsa, Oklahoma, American Association of Petroleum Geologists, p. 533-550.

Beebe, W.B., ed., 1968, Natural gases of North America: American Association of Petroleum Geologists Memoir 9, two vol.

Bellizzia, A., N. Pimentel, and S. Rodriguez, 1981, Minerales de Venezuela: Ministerio de Energía y Minas, Boletin de Geología, Publicación Especial no. 8.

Berry, G.W., P.J. Grim, and J.A. Ikelman, 1980, Thermal springs list for the United States: National Oceanic and Atmospheric Administration Key to Geophysical Records Documentation no. $12,59 \mathrm{p}$.

Bishop, W.F., 1980, Petroleum geology of northern Central America: Journal of Petroleum Geology, v. 3, p. 3-59.

Braislin, D.B., D.D. Hastings, and P.D. Snavely, Jr., 1971, Potential of western Oregon and Washington and adjacent continental margin, in I.H. Cram, ed., Future petroleum provinces of the United States-their geology and potential: American Association of Petroleum Geologists Memoir 15, v. 1, p. 229-238.
British Columbia Ministry of Energy, Mines and Petroleum Resources, 1985, Hydrocarbon and byproduct reserves in British Columbia, Victoria, British Columbia, December 31, 1984: Petroleum Resources Division, Ministry of Energy, Mines and Petroleum Resources.

Brockmeulen, H., C. Barker, and P.A. Dickey, 1983, Geology and geochemistry of crude oils, Bolivar coastal fields, Venezuela: American Association of Petroleum Geologists Bulletin, v. 67, p. 242-270.

Browning, J.M., 1980, Facts and principles of Latin American oil occurrence, in A.D. Miall, ed., Facts and principles of world petroleum occurrences: Canadian Society of Petroleum Geologists Memoir 6, p. 823-855.

California Division of Oil and Gas, 1984, 70th annual report of the state oil and gas supervisor, 1984: California Department of Conservation, Division of Oil and Gas, Publication PRO6, 151 p.

Canadian Petroleum Association, 1985, 1984 statistical handbook: Calgary, Canadian Petroleum Association.

Canfield, R.W., G. Bonilla, and K.R. Robbins, 1982, Sacha oil field of Ecuadorian Oriente: American Association of Petroleum Geologists Bulletin, v. 66, p. 1076-1090.

Comisión Federal de Electricidad, 1985, Present and planned utilization of geothermal resources in Mexico, in C. Stone, ed., International symposium on geothermal energy, international volume: Davis, California, Geothermal Resources Council p. 135-140.

Conn D.H., 1987, Distribución general y características del recurso carbón en los Ándes: Circum-Pacific Council for Energy and Mineral Resources Earth Science Series (in press)

Corrales, M.F., 1985, Costa Rica country update report, in C. Stone, ed., International symposium on geothermal energy, international volume: Davis, California, Geothermal Resources Council, p. 57-64.

Coury, A.B., T.A. Hendricks, and T.F. Tyler, 1978, Map of prospective hydrocarbon provinces of the world: U.S. Geological Survey Miscellaneous Field Studies Map MF1044A, North and South America, scale 1:20,000,000.

Crain, W.E., W.E. Mero, and D. Patterson, 1985, Geology of the Point Arguello discovery: American Association of Petroleum Geologists Bulletin, v. 69, p. 537-545.

Crandall, J.T., and T.L. Sadlier-Brown, 1977, Data on geothermal areas, Cordilleran Yukon, northwest territories, and adjacent British Columbia, Canada: Geological Survey of Canada Open File 427.

Crowell, J.C., 1974, Origin of late Cenozoic basins in southern California, in W.R. Dickinson, ed., Tectonics and sedimentation: Society of Economic Paleontologists and Mineralogists Special Paper 22, p. 190-204.

Crowell, J.C., and others, 1975, San Andreas fault in southern California; a guide to the San Andreas fault from Mexico to Carrizo Plain: California Division of Mines and Geology, Special Report 118, 272 p., map scale 1:750,000.

Culbertson, W.C., and J.K. Pitman, 1973, Oil shale, in D.A. Brobst and W.P. Pratt, eds., United States mineral resources: U.S. Geological Survey Professional Paper 820, p. 497-503. 
Cunningham, C.G., and others, 1984, Earth and water resources and hazards in Central America: U.S. Geological Survey Circular 925, 40 p.

Curran, J.R., K.B. Hall, and R.F. Herron, 1971, Geology, oil fields, and future petroleum potential of Santa Barbara Channel area, California, in I.H. Cram, ed., Future petroleum provinces of the United States-their geology and potential: American Association of Petroleum Geologists Memoir 15, v. 1, p. 192-211.

Curry, W.H., III, 1984, Washington's Columbia basin-a possible new U.S. petroleum basin: Oil and Gas Journal, v. 82 , p. $115-118$.

DeGolyer and McNaughton, 1985, Twentieth century petroleum statistics, 1984: Dallas, DeGolyer and McNaughton, 126 p. Demaison, G.J., 1976, Tar sands give clues to search for supergiant oil fields, in Tomorrow's oil from today's provinces: Selected Papers, 51st American Association of Petroleum Geologists Pacific Section Meeting, Miscellaneous Publication 24, p. 90-97

1978, Tar sands and supergiant oil fields, in D.A. Redford and A.G. Winestock, eds., The oil sands of Canada-Venezuela 1977: Canadian Institute of Mining and Metallurgy Special Volume 17, p. 9-16.

De Grys, A., J. Vera, P. Goossens, 1970, A note on the hot springs of Ecuador: Geothermics, Special Issue 2, v. 2, Pt. 2, p. 1400-1404.

Di Pippo, R., 1980, Geothermal energy as a source of electricity: U.S. Department of Energy, Washington, D.C., DOE/ RA/28320-1, 370 p.

1983, World-wide geothermal power and development: an overview and update: Seventh Annual Geothermal Conference and Workshop Proceedings, September 1983: Palo Alto, California Electric Power Research Institute, EPRI AP3271, p. 6.1-6.16.

1985, Geothermal electric power, the state of the world1985, in C. Stone, ed., 1985 International Symposium on Geothermal Energy, international volume: Davis, California, Geothermal Resources Council, p. 57-64.

Drummond, K.J., 1973, Canadian Arctic islands, in R.G. McCrossan, ed., The future petroleum provinces of Canada - their geology and potential: Canadian Society of Petroleum Geologists Memoir 1, p. 443-472.

1981, Plate-Tectonic Map of the Circum-Pacific Region, Northeast Quadrant: American Association of Petroleum Geologists, scale 1:10,000,000.

1983, Geologic Map of the Circum-Pacific Region, Northeast Quadrant. American Association of Petroleum Geologists, scale 1:10,000,000.

1984a, Geodynamic Map of the Circum-Pacific Region, Northeast Quadrant: American Association of Petroleum Geologists, scale 1:10,000,000.

1984b, Mineral-Resources Map of the Circum-Pacific Region, Northeast Quadrant: American Association of Petroleum Geologists, scale 1:10,000,000.

Duran R., R.A., and C.A. Arboleda 0., 1987, Coal resources of Colombia: Circum-Pacific Council for Energy and Mineral Resources Earth Science Series (in press).
Energy Resources Conservation Board of Alberta, 1985, Reserves of coal, province of Alberta: ERCB report ST 85-31.

Evernden, J.F., and R.W. Kistler, 1970, Chronology of emplacement of Mesozoic batholithic complexes in California and western Nevada: U.S. Geological Survey Professional Paper 623, 42 p.

Fernandez-Rivas, R., 1970, Geothermal resources of Guatemala, Central America: Geothermics, Special Issue, v. 2, Pt. 2, p. 1015-1025.

Fisher, M.A., 1979, Structure and tectonic setting of continental shelf southwest of Kodiak Island, Alaska: American Association of Petroleum Geologists Bulletin, v. 63, p. 301-310.

1980, Petroleum geology of Kodiak shelf, Alaska: American Association of Petroleum Geologists Bulletin, v. 64 , p. $1140-1157$

Fisher, M.A., W.W. Patton, Jr., and M.L. Holmes, 1982, Geology of Norton basin and continental shelf beneath northwestern Bering Sea, Alaska: American Association of Petroleum Geologists Bulletin, v. 66, p. 255-285.

Frezon, S.E., 1974, Summary of 1972 oil and gas statistics for onshore and offshore areas of 151 countries: U.S. Geological Survey Professional Paper 885, $162 \mathrm{p}$.

Fritts, S.G., and L.H. Fisk, 1985, Tectonic model for formation of Columbia basin: implications for oil, gas potential of north central Oregon: Oil and Gas Journal, v. 83, no. 34 , p. 84-88.

García, N., and B. Salazar, 1985, Colombia country update, in C. Stone, ed., 1985 International Symposium on Geothermal Energy, international volume: Davis, California, Geothermal Resources Council, p. 53-56.

Golovchenko, X., R.L. Larson, and W.C. Pitman III, 1981, Magnetic lineations, in K.J. Drummond, Plate-Tectonic Map of the Circum-Pacific Region, Northeast Quadrant American Association of Petroleum Geologists, scale 1:10,000,000.

Grantz, A., S.L. Eittreim, and 0.T. Whitney, 1981, Geology and physiography of the continental margin north of Alaska and implications for the origin of the Canada Basin, in A.E.M. Nairn, M. Churkin, Jr., and F.G. Stehli, eds., The ocean basins and margins, v. 5: the Arctic Ocean: New York, Plenum Press, p. 439-492.

Grantz, A., and S.D. May, 1982, Rifting history and structural development of the continental margin north of Alaska, in C.L. Drake and J.S. Watkins, eds., Studies in continental margin geology: American Association of Petroleum Geologists Memoir 34, p. 77-100.

Guild, P.W., and others, 1985, Explanatory notes for the Mineral-Resources Map of the Circum-Pacific Region, Northeast Quadrant: Tulsa, Oklahoma, American Association of Petroleum Geologists, 48 p.

Guzman, A.B., 1981, Petroleum prospects in Mexico's Altar Desert: Oil and Gas Journal, v. 79, no. 34, p. 111-126.

Guzman, E.J., and A.E. Guzman, 1981, Petroleum geology of Reforma area, southeast Mexico, and explanatory effort in Baja California, northwest Mexico, in M.T. Halbouty, ed., Energy resources of the Pacific region: American Association of Petroleum Geology Studies in Geology 12, p. 1-11. 
Haffman, S.E., M.J. Lippmann, R. Zelver, and J.H. Howard, 1984, Geologic interpretation of geothermal fluid movements in Cerro Prieto field, Baja California, Mexico: American Association of Petroleum Geologists Bulletin, v. 68 , p. $18-30$.

Halbouty, M.T., and others, 1970, World's giant oil and gas fields, geologic factors affecting their formation and basin classification: part I, giant oil and gas fields; part II, factors affecting the formation of giant oil and gas fields, and basin classification, in M.T. Halbouty, ed., Geology of giant petroleum fields: American Association of Petroleum Geologists Memoir 30, p. 502-555.

Hay-Roe, H., J.F. Zuñiga, and A. Montoya, 1983, Geology and entrapment history of the Portachuelo Salina pool, Talara basin, Peru: Journal of Petroleum Geologists, v. 6, p. 139164.

Hills, L.V., ed., 1974, Oil sands-fuel of the future: Canadian Society of Petroleum Geologists Memoir 3, 263 p.

Hoskins, E.G., and J.R. Griffiths, 1971, Hydrocarbon potential of northern and central California offshore, in I.H. Cram, ed., Future petroleum provinces of the United States-their geology and potential: American Association of Petroleum Geologists Memoir 15, v. 1, p. 212-228.

Isaacs, C.M., 1984, The Monterey-key to offshore California boom: Oil and Gas Journal, v. 82, no. 2, p. 75-81.

Ise, F.T., 1985, Washington and Oregon-are there other rocks to explore: Oil and Gas Journal, v. 83, no. 32, p. 112-115.

Jarrin, A., 1976, Exploration and development of hydrocarbon resources in Pacific basins of Ecuador-summary, in M.T. Halbouty, J.C. Maher, and H.M. Lian, eds., Circum-Pacific energy and mineral resources: American Association of Petroleum Geologists Memoir 25, p. 328-330.

Jessop, A.M., 1985, Geothermal energy in Canada, in C. Stone, ed., 1985 International Symposium on Geothermal Energy, international volume: Davis, California, Geothermal Resources Council, p. 37-42.

Kashfi, M.S., 1983, Geology and hydrocarbon prospects of Jamaica: American Association of Petroleum Geologists Bulletin, v. 67, p. 2117-2124.

1972, Coal deposits of western and northern Canada, in G.B. Mellon, J.W. Kramers, and E.J. Seagel, eds., First Geological Conference on Western Canadian Coal proceedings: Alberta Research Council Information Series, no. 60 , p. $1-8$.

Latour, B.A., 1976, Coal resources of Canadian Cordillerasummary, in M.T. Halbouty, J.C. Maher, and H.M. Lian, eds., Circum-Pacific energy and mineral resources: American Association of Petroleum Geologists Memoir 25 , p. 105-109.

Latour, B.A., and L.P. Chrismas, 1970, Preliminary estimate of measured eoal resources including reassessment of indicated and inferred resources in western Canada: Canadian Geological Survey Paper 70-58, 14 p.

Leonard, R., 1983, Geology and hydrocarbon accumulations, Columbus basin, offshore Trinidad: American Association of Petroleum Geologists Bulletin, v. 73, p. 1081-1093.
Lerand, M., 1973, Beaufort Sea, in R.G. McCrossan, ed., The future petroleum provinces of Canada-their geology and potential: Canadian Society of Petroleum Geologists Memoir 1, p. 315-386.

Lewis, T.J., and J.G. Souther, 1978, Meager Mountain, British Columbia-a possible geothermal energy resource: Ottawa, Canada, Energy, Mines and Resources, Geothermal Series 9, $17 \mathrm{p}$.

Magoon, L.B., and G.E. Claypool, 1981, Petroleum geology of Cook Inlet basin, Alaska-an exploration model, in M.T. Halbouty, ed., Energy resources of the Pacific region: American Association of Petroleum Geologists Studies in Geology 12, p. 355-374.

Marlow, M.S., A.K. Cooper, and J.R. Chilas, 1983, Tectonic evolution of Gulf of Anadyr and formation of Anadyr and Navarin basins: American Association of Petroleum Geologists Bulletin, v. 67, p. 646-665.

Martinez, A.R., and others, 1984, Classification and nomenclature systems for petroleum and petroleum reserves: Proceedings of the World Petroleum Congress, v. 2, p. 325-339.

Meyer, R.F., I.C. Wynn, and J.C. Olson, eds., 1984, The future of heavy crude and tar sands; Second International Conference, February 7-17, 1982, Caracas, Venezuela: New York, McGraw-Hill, 1338 p.

Meyerhoff, A.A., E.A. Krieg, J.D. Cloos, and I. Taner, 1983, Petroleum potential of Puerto Rico: Oil and Gas Journal, v. 81 , no. 51 , p. $113-120$.

Miller, J.B., and others, 1958, Habitat of oil in the Maracaibo basin, Venezuela, in L.G. Weeks, ed., Habitat of oil: Tulsa, Oklahoma, American Association of Petroleum Geologists, p. 601-640.

Moore, G.W., 1981, Plate perimeters and motion vectors, in K.J. Drummond, Plate-Tectonic Map of the Circum-Pacific Region, Northeast Quadrant: American Association of Petroleum Geologists, scale 1:10,000,000.

Morales, L.G., 1958, General geology and oil occurrences of middle Magdalena Valley, Colombia, in L.G. Weeks, ed., Habitat of oil: Tulsa, Oklahoma, American Association of Petroleum Geologists, p. 641-695.

Muffler, L.J.P., ed., 1979, Assessment of geothermal resources of the United States-1978: U.S. Geological Survey Circular 790, 163 p. (and accompanying map Geothermal energy in the western United States: National Geophysical and Solar-Terrestrial Data Center, National Oceanic and Atmospheric Administration, scale 1:2,500,000).

Offshore, 1983, Point Arguello tops California's priorities: Offshore, v. 43, no. 7, p. 81-82.

Ogle, B.A., 1981, Oil and gas exploration offshore central and northern California, in M.T. Halbouty, ed., Energy resources of the Pacific region: American Association of Petroleum Geologists Studies in Geology 12, p. 376-389.

Oil and Gas Journal, 1961-1985, Worldwide report issues: Oil and Gas Journal, v. 59-83.

1985, Exploration pace due to pick up in north Guatemala: Oil and Gas Journal, v. 83, no. 34, p. 40.

1985, Offshore southarn California: Oil and Gas Journal, v. 83 , no. 2 , p. $55-77$. 
Organización Latino Americana de Energía (OLADE), 1983, Latin American Seminar on geothermal exploration, Quito, Ecuador, September 5-9, 1983 (OLADE reports for Colombia, Ecuador, El Salvador, Guatemala, Honduras, Nicaragua, Panamá, Perú, Venezuela).

Parker, C.A., 1986, Cano-Limon reservoir properties suggest high recovery factor: Oil and Gas Journal, v. 84, no. 19, p. 55-58.

Parker, R.5., 1971, Petroleum potential of southern California offshore, in I.H. Cram, ed., Future petroleum provinces of the United States-their geology and potential: American Association of Petroleum Geologists Memoir 15, v. 1, p. 178-191.

Parodi, A.I., 1974, Feasibility of the development of the geothermal energy in Peru: Second United Nations Symposium on the Development and Uses of Geothermal Resources Proceedings, San Francisco, California, May 2029, 1975, v. 1, p. 227-231.

Peterson, J.A., 1983, Petroleum geology and resources of southeastern Mexico, northern Guatemala, and Belize: U.S. Geological Survey Circular 760, 44 p.

1985, Petroleum geology and resources of northeastern Mexico: U.S. Geological Survey Circular 943, 30 p.

Ramirez, A.H., 1985, Country update-Panama, in C. Stone, ed., International symposium on geothermal energy, international volume: Davis, California, Geothermal Resources Council, p. 155-156.

Roadifer, R.E., 1986a, Size distributions of world's largest known oil, tar accumulations: Oil and Gas Journal, v. 84, no. 8 , p. 93-100.

$1986 \mathrm{~b}$, How heavy oil occurs worldwide: Oil and Gas Journal, v. 84, no. 7, p. 111-115.

St. John, B., 1980, Sedimentary basins of the world: Tulsa, Oklahoma, American Association of Petroleum Geologists, scale 1:40,000,000.

St. John, B., A.W. Bally, and H.D. Klemme, 1984, Sedimentary provinces of the world-hydrocarbon productive and nonproductive: Tulsa, Oklahoma, American Association of Petroleum Geologists, map and text, scale 1:31,368,000.

Sanders, R.B., 1984, Alaska's coal resources-an international view, in S.T. Watson, ed., Transactions of the Third Circum-Pacific Energy and Mineral Resources Conference, August 22-28, 1982, Honolulu: Circum-Pacific Council for Energy and Mineral Resources, p. 507-512.

Servicio Nacional de Electricidad, 1970, Geothermal resources of Costa Rica: Geothermics Special Issue 2, pt. 2, p. 10261029.

Smith, J.H., 1980, Oil shale resources of the United States; Colorado School of Mines: Minerals and Energy Resources, v. 23, 20 p.

Stauffer, K.W., 1984, Rio Zulia field, Colombia, in S.T. Watson, ed., Transactions of the Third Circum-Pacific Energy and Mineral Resources Conference, August 22-28, 1982, Honolulu: Circuin-Pacific Council for Energy and Mineral Resources, p. 233-242.

Steffy, D.H., R.F. Turner, G.C. Martin, and T.0. Flett, 1985, Evolution and petroleum geology of the Navarin basin, Bering Sea, Alaska: Oil and Gas Journal, v. 83, no. 31, p. 116-124.
Stewart-Gordon, J.T., 1984, Discoveries, high potential spur interest in Colombia: World Oil, v. 198, p. 147-150.

Tiratsoo, E.N., 1979, Natural gas: Beaconsfield, United Kingdom, Scientific Press, Ltd., ed. 3, 360 p.

1984, Oil fields of the world: Reading, United Kingdom, Creative Press, Ltd., ed. 3, 392 p.

Travis, R.B., 1953, La Brea-Parmnas oil field, northwestern Peru: American Association of Petroleum Geologists Bulletin, v. 37, p. 2093-2118.

Vedder, J.G., and others, 1974, Preliminary report on the geology of the continental borderland of southern California: U.S. Geological Survey Miscellaneous Field Studies MF$624,34 \mathrm{p}$.

Wallis, W.5., 1981, Oil and gas exploration, offshore southern California, in M.T. Halbouty, ed., Energy resources of the Pacific region: American Association of Petroleum Geologists Studies in Geology 12, p. 383-389.

Waring, G.A., 1965, Thermal springs of the United States and other countries of the world-a summary: U.S. Geological Survey Professional Paper 492, 383 p.

Wennekers, J.H.N., and others, 1979, Heavy oil, tar sands play key role in Alberta, Saskatchewan, production: Oil and Gas Journal, v. 77, p. 290-304; v. 77, p. 193-198.

Wood, G.H., and W.V. Bour, III, 1986, Coal map of North America: U.S. Geological Survey, scale 1:5,000,000 (in press).

Woodside, P.R., 1981, Petroleum geology of Trinidad and Tobago: U.S. Geological Survey Open-File Report 81-660, 39 p.

Youngquist, W., 1958, Controls of oil occurrence in La BreaParinas field, northern coastal Peru, in L.G. Weeks, ed., Habitat of oil: Tulsa, Oklahoma, American Association of Petroleum Geologists, p. 696-720.

Zentano, M.A., A. Juarez, and J. Meneses, 1984, Exploration and development of the Campeche Sound and ChiapasTabasco area: Eleventh World Petroleum Congress Proceedings, v. 2, p. 101-109.

\section{SOUTHEAST QUADRANT}

Ahlfeld, F.E., 1969, Geografía física de Bolivia, in Enciclopedia Boliviana: La Paz, Bolivia, p. 7-239.

Ali, W.M., 1987, Trinidad-Tobago information, Informal communication to this Energy-Resources Map Panel.

Almeida, E., 1983, Summary of the status of geothermal exploration in Ecuador as carried out by the Ecuatorian Institute of Electrification (INECEL), in Latin American seminar on geothermal exploration: Quito, Ecuador, Sept. 5-9, 1983, Organización Latino Americana de Energía (OLADE), 6 p.

American Society for Testing Materials, 1983, Annual book of ASTM Standards, v.05.05, gaseous fuels; coal and coke: Philadelphia, American Society for Testing Materials, $531 \mathrm{p}$.

Arango, E.E., Buitrago, A.J., Cataldi, R., Ferrara, G.C., Panichi, C., and Villegas, J.V., 1970, Preliminary study of the Ruiz Geothermal Project (Colombia): Geothermics, Special Issue, v. 2, pt. 1, p 43-56. 
Baldock, J.W., 1982, Geología del Ecuador: Quito, Ecuador Dirección General de Geología y Minas, Special Publication, p. 1-66.

Bell, J.S., 1974, Venezuelan Coast Ranges, in Spencer, A.M., ed., Mesozoic-Cenozoic orogenic belts: London, The Geological Society, Special Publication, no. 4, p. 683703.

Bellizia, A., Parra, N., Pimentel, N., and Sanchez de P., A., 1988, Informal communication to this Energy-Resources Map Panel: Caracas.

Bergmann, A.J., and Xicoy, A.N., 1990, Recursos Carboníferos Argentinos, in Geology of the Andes and its relation to hydrocarbon and mineral resources: Houston, Texas, Circum-Pacific Council, Earth Science Series, v. 11, p. 131-137.

Bigarella, J.J., 1973, Geology of the Amazonas and Parnaiba Basins, in Nairn, A.E.M., and Stehli, F.G., The ocean basin and margins, the South Atlantic: New York, Plenum Press, v. 1, p. $25-86$.

Borrello, A.V., 1978, Mapa geotectónico de la República Argentina: Buenos Aires, Secretaría de Estado de Minería scale $1: 2,500,000$.

Bueno, R., 1990, Hydrocarbon resources in the Sub-Andean basins of Colombia, in Geology of the Andes and its relation to hydrocarbon and mineral resources: Houston, Texas, Circum-Pacific Council, Earth Science Series, v. 11 , fig. 12 , p. $345-362$

Campbell, C.J., 1974, Colombian Andes, in Spencer, A.M., ed., Mesozoic-Cenozoic orogenic belts: The Geological Society of London, Special Publication, no. 4, p. 705-724.

Casadevall, T., 1980, Assessment of geothermal potential in the Republic of Argentina. Assessment carried out by the U.S. Department of Energy in cooperation with Secretaría de Planeamiento of the Republic of Argentina, $15 \mathrm{p}$.

Case, J.E., 1974, Major basins along the continental margin of northern South America, in Burk, C.A., and Drake, C.L., eds., The geology of continental margins: New York, Springer-Verlag, p. 733-741.

Conn, D.H., 1990, Distribución general y características del recurso carbón en los Andes, in Symposium Geology of the Andes and its relation to hydrocarbon and mineral resources: Houston, Texas, Circum-Pacific Council.

Corvalan Diaz, J., 1981, Plate-tectonic map of the Circum-Pacific region, Southeast Quadrant: Tulsa, Oklahoma, Circum-Pacific Council, scale 1:10,000,000.

Corvalan Diaz, J., 1985, Geologic map of the Circum-Pacific region, Southeast Quadrant: Tulsa, Oklahoma, CircumPacific Council, scale 1:10,000,000.

Crawford, F.D., and Szelewsky, C.E., 1984, Geology and exploration in the Takutu Graben of Guyana: Oil and Gas Journal, March 5, 1984, v. 82., no. 10, p. 122-129.

DeGolyer and McNaughton, 1988, Twentieth century petroleum statistics, 1987: Dallas, DeGolyer and McNaughton, $126 \mathrm{p}$.

De Grys, A., Vera, J., and Goossens, P., 1970, A note on the hot springs of Ecuador: Geothermics, Special Issue 2, v. 2. pt. 2, p. 1400-1404.

Del Solar, C., and Eyzaguirre, V.R., 1985, Informal communication to the Energy-Resources Map Panel: Quito, Ecuador.
Dirección General de Geologia, 1984, Principales depósitos carboníferos: Lima, scale 1:10,000,000.

Dirección General de Geologia, 1984, Mapa del potencial geotérmico del Perú: Lima, scale 1:10,000,000.

Dirección de Geologia y Minas del Ecuador, 1982, Mapa Geológico Nacional de las República de Ecuador: Quito, Ecuador, Ministerio de Recursos Naturales y Energéticos, scale $1: 1,000,000$.

Drummond, K.J., 1986, Energy Resources Map of the CircumPacific Region, Northeast Quadrant: Tulsa, Oklahoma, Circum-Pacific Council, 72 p., scale 1:10,000,000.

Duque-Caro, H., 1984-1985, Informal communications to the Energy-Resources Map Panel: Bogota, Colombia.

Empresa Nacional del Petróleo, 1981, Plans for exploration and exploitation of hydrocarbons: Santiago de Chile, Special Publication.

Empresa Nacional del Petróleo, 1980, Internal publication of Empresa Nacional del Petróleo: Santiago de Chile.

Feo-Codecido, G., 1972, Contribución a la estratigrafía de la Cuenca Barinas-Apure, in ${ }^{-M e m o i r}$ IV Congreso Geológico Venezolano: Caracas, Noviembre 1969, v. II, Publ. Esp. 5, p. 773-795.

Fernandez Garrasino, C., 1982, Algunos rasgos geológicos de la Cuenca Amazónica Ecuatoriana: Buenos Aires, Actas del Quinto Congreso Latinoamericano de Geologia, Tomo I, p. 81-95.

Flores Williams, H., 1978, Chilean, Argentine, and Bolivian coals, in Kottlowski, F.E., Cross, A.T., and Meyerhoff, A.A., eds., Coal resources of the Americas: Boulder, Colorado, The Geological Society of America, Special Paper 179, p. 1-14.

Gabela, V.H., 1990, Exploration and Geologic Framework of the Caño Limón Oil Field, Llanos Orientales de Colombia, in Geology of the Andes and its relation to hydrocarbon and mineral resources: Houston Texas, Circum-Pacific Council, v. 11, p. 363-382.

Gansser, A., 1973, Facts and theories on the Andes: Geological Society of London Journal, v. 129, p. 93-131.

Gonzalez, E., 1965, La cuenca petrolífera de Mangallanes: Santiago de Chile, Revista Minerales, v. 20, no. 91, p. 1-19.

Gonzalez, E., 1985, Informal communication to the EnergyResources Map Panel: Santiago de Chile.

Herrero Olivares, E., 1985, Informal communication to the Energy-Resources Map Panel: Caracas Venezuela.

Herron, E.M., Cande, S.C., and Hall, B.R., 1981, An active spreading center collides with a subduction zone: a geophysical survey of the Chile Margin triple junction, in Kulm, L.D., Dymond, J., Daseh, E.J., and Hussong, D.M., eds., Nazca Plate: Crustal formation amd Andean convergence: Geological Society of America,.Memoir 154, p. $683-702$.

Instituto de Geológia y Mineria, 1977, Sinopsis explicativa del mapa geológico del Perú: Lima, p 1-41, scales $1: 1,000,000$ and $1: 4,000,000$.

International Petroleum Encyclopedia, 1988, Tulsa, Oklahoma, Energy Group of PennWell Publishing Co., v. 21.

Kottlowski, F.E., Cross, A.T., and Meyerhoff, A.A., eds., 1978, Coal resources of the Americas: Boulder, Colorado, The Geological Society of America, Special Paper 179, p. 1-90. 
Lahsen, A., 1986, Origen y potencial de energía geotérmica en los Andes de Chile, in Frutos, J., Oyarzun, R.O., and Pincheira, M., eds., Geología y recursos minerales de Chile: Santiago de Chile, Universidad de Concepción, I, p. 423-438.

Latour, B.A., and Chrismas, L.P., 1970, Preliminary estimate of measured coal resources including reassessment of indicated and inferred resources in western Canada: $\mathrm{Ca}$ nadian Geological Survey Paper 70-58, 14 p.

Lesta, P., Digregorio, J., and Mozetic, M.E., 1985, Presente y futuro de la exploración de petróleo en las Cuencas Subadinas Argentinas, in II Simposio Bolivariano Exploración Petrolera de las Cuencas Subandinas: Bogota, Colombia, Asociación Colombiana de Geólogos y Geofisicos del Petróleo, Publicación III, p. 1-34.

Lesta, P., Digregorio, J., and Pozzo, A., 1973, Resumean de las principales cuencas sedimentarias de la Argentina, in Evaluación de formaciones en la Argentina: Buenos Aires, Schlumberger Special Publication, p. 7-29.

Lonsdale, P., 1978, Ecuadorian subduction system: Tulsa, Oklahoma, American Association of Petroleum Geologists Bulletin, v. 62, no. 12 , p. 2454-2477.

Mainardi, E.C., Turic, M.A., and Stubelj, R., 1980, Consideraciones sobre las Cuencas Costa Afuera de la República Argentina: Buenos Aires, Special Publication, Dirección Exploración Yacimientos Petroliferous Fiscales, p. 1-9.

Martinez, A.R., and others, 1984, Classification and nomenclature systems for petroleum and petroleum reserves: London, Study Group Report, 11th World Petroleum Congress, v. 2, p. 323-343.

Martinez, A.R., 1987, The Orinoco Oil Belt, Venezuela: Beaconsfield, England, Journal of Petroleum Geology, v. 10 , no. 2, p. 125-134.

Mordojovich, C., 1981, Sedimentary Basin of Chilean Pacific Offshore, in Halbouty, M., ed., Energy resources of the Pacific region: Tulsa, Oklahoma, American Association of Petroleum Geologists, Studies in Geology, no. 16, p. 63-82.

Nur, A., and Ben-Avraham, Z., 1981, Volcanic gap and the consumption of aseismic ridges in South American, in Kulm, L.D., Dymond, J., Daseh, E.J., and Hussong, D.M., eds., Nazca Plate: Crustal formation amd Andean convergence: The Geological Society of America, Memoir 154, P. 729-740.

Nygren, W.E., 1950, The Bolivar Geosyncline of northwestern South America: Tulsa, Oklahoma, American Association of Petroleum Geologists Bulletin, v. 34, p. 1998-2006.

Olive, W.W., 1978, Coal deposits of Latin America, in Kottlowski, F.E., Cross, A.T., and Meyerhoff, A.A., eds., Coal resources of the Americas: Boulder, Colorado, Geological Society of the Americas, Special Paper 179, p. 59-64

Organización Latino Americana de Energía, 1983, Current status of geothermics in Chile: Quito, Ecuador, Latin American Seminar on Geothermal Exploration, September 59, 1983, Organización Latino Americana de Energía (OLADE), 16 p.
Organización Latino Americana de Energía, 1983, Geothermal energy in Venezuela: Quito, Ecuador, Latin American Seminar on Geothermal Exploration, September 59, 1983, Organización Latino Americana de Energía (OLADE), 8 p.

Organización Latino Americana de Energía, 1983, Prospects for geothermal development in Perú and accomplishments so far: Quito, Ecuador, Latin American Seminar on Geothermal Exploration, September 5-9, 1983, Organización Latino Americana de Energía (ORLADE), 8 p.

Organización Latino Americana de Energía, 1983, Current status of geothermal investigations in the Volcanic Massif del Ruiz: Quito, Ecuador, Latin American Seminar on Geothermal Exploration, September 5-9, 1983, Organización Latino Americana de Energía (OLADE), $11 \mathrm{p}$.

Palacio, M., and Llambías, 1978, Las Fuentes Termales del Volcán Domuyo, provincia de Neuquén: Buenos Aires, VII Congreso Geológico Argentino, II, p. 145-149.

Parodi, A.I., 1974, Feasibility of the development of the geothermal energy in Peru, in Second United Nations Symposium on the development and use of geothermal resources, Proceedings: San Francisco, California, May 2029, 1975, v. 1, p. 227-231.

Perez de Mejia, D., Kiser, G.D., Maximowitsch, B., and Young, G.A., 1980, Geología de Venezuela, in Evaluación de Formaciones en Venezuela: Caracas, Schlumberger Surenco S.A., Special Publication, p. I1-123.

Petersen, C.R., 1978, Coal resources of Peru, in Kottlowski, F.E., Cross, A.T., and Meyerhoff, A.A., eds., Coal resources of the Americas: Boulder, Colorado, Geological Society of America, Special Paper 179, p.35-42.

Petters, V., 1960, The habitat of oil and gas in Colombia, Ecuador, and Peru: Lima, Unpublished report of International Petroleum Company.

Rosania Schiavone, G., 1985, Informal communication to this Energy-Resources Map Panel: Quito, Ecuador.

St. John, B., Bally, A.W., and Klemme, H.D., 1984, Sedimentary provinces of the world-hydrocarbon productive and non-productive: Tulsa Oklahoma, American Association of Petroleum Geologists, p. 2-35, scale 1:31,368,000.

Second United Nations Symposium on the development and use of geothermal resources, 1975, Proceedings: San Francisco, California, May 20-25, v. 1, 884 p.

Servicio Geológico Nacional, 1982, Mapa Geológico de la República Argentina: Buenos Aires, Secretaría de Industria y Minería, scale 1:2,500,000.

Servicio Nacional de Geología y Minería, 1982, Mapa Geológico de Chile: Santiago de Chile, maps 1 to 6, scale $1: 1,000,000$.

Servicio Nacional de Geología y Minería, 1969, Mineral index map, Republic of Ecuador: Quito, scale 1:1,000,000.

Solis Iriarte, R., 1985, Informal communication to this EnergyResources Map Panel: La Paz, Bolivia.

Suescun-Gomez, D., 1978, Coal deposits of Colombia, in Kottlowski, F.E., Cross, A.T., and Meyerhoff, A.A., eds., Coal resources of the Americas: Boulder, Colorado, Geological Society of America, Special Paper 179, p. 49-55. 
Touzett, H., and Sanz, R.V., 1985, Presente y futuro de la exploración petrolera de las Cuencas Subandinas, Perú, in II Simposio Bolivariano - Exploración petrolera de las Cuencas Subandinas: Bogotá, Colombia, Asociación Colombiana de Geólogos y Geofísicos del Petróleo, Publicación III, p. 1-93.

Turic, M., 1981, Cuencas sedimentarias en la Argentina: Buenos Aires, Comunicación Yacimientos Petroliferous Fiscales, p. 3-39.

UNESCO, 1978, Tectonic map of South America, explanatory notes: Brasilia, Commission for the Geological Map of the World.

United Nations, 1987, Energy Statistics Yearbook: New York, Department of International Economic and Social Affairs - Statistical Office, United Nations.

Vicente, O.M., 1974, Personal communication to M.R. Yrigoyen: Buenos Aires.

Waring, G.A., 1965, Thermal springs of the United States and other countries of the world, a summary: U.S. Geological Survey, Professional Paper 492, 383 p.

Wood, G.H., 1984, Coal fields and coal occurrences, Informal communication to this Energy-Resources Map Panel.

Yacimientos Petroliferous Fiscales Bolivianos, 1972, Resumen de la geología petrolera de Bolivia: La Paz, Bolivia, Special Publication Yacimientos Petroliferous Fiscales Bolivianos.

Yrigoyen, M.R., and Urien, C.M., 1988, Cuadro geoestructural de América del Sur, in Facultad de Ciencias Naturales, Universidad Nacional de Tucumán, eds., Geología de America de Sur: Tucumán, Argentina, p. 17-106.

Yrigoyen, M.R., 1982-1988, Informal communication to the Energy-Resources Map Panel.

Yrigoyen, M.R., 1990, Subandean hydrocarbon resources of Argentina, in Geology of the Andes and its relation to hydrocarbon and mineral resources: Houston, Texas, Circum-Pacific Council, Earth Science Series, v. 11, p. 439-452.

Zambrano, J.J., 1981, Distribución y evolución de las cuencas sedimentarias en al continente Sudamericano durante el Jurásico y Cretácico, in Volkheimer, W., and Musacchio, eds., Cuencas sedimentarias del Jurásico y Cretácico de América del sur: Porto Alegre, Brazil, II Congreso Latinoamericano de Paleontología, p. 9-44.

\section{NORTHWEST QUADRANT}

Alcaraz; A., 1974, Potential utilization of heat energy from Philippine volcanic areas, in Colp, J.L., and Furumoto, A.S., eds., Utilization of volcano energy, Hilo, Hawaii, February 4-8, 1974, Proceedings: Sandia Laboratories, N. Mex., United States-Japan Cooperative Science Seminar, p. 169-190.

Alzwar, M., 1986, Geothermal energy potential related to active volcanism in Indonesia: Geothermics, v. 15, p. 601-607.

Anwar, J., and Husain, M., 1980, Origin of petroleum and suitability of Bangladesh geological environment for the occurrence of oil and gas, in Petroleum and mineral re- sources of Bangladesh: Ministry of the People's Republic of Bangladesh, p. 19-29.

Association of Southeast Asian Nations Council on Petroleum (ASCOPE), 1984, Tertiary sedimentary basins of the southwest Sulu Sea, Makassar Strait, and Jawa Seastratigraphy, structure and hydrocarbon occurrences: Technical Paper TP/3.

- 1985, The stratigraphic correlation study of the Andaman Sea-Strait of Malacca: Technical Paper TP/4.

Aw, P.C., Chen, S.P., Lau, J.W.E., and Leong, K.M., 1978, Onshore sedimentary basins of Malaysia, in United Nations Economic and Social Commission for Asia and the Pacific (ESCAP), Atlas of stratigraphy I, Burma, Malaysia, Thailand, Indonesia, Philippines (Stratigraphic correlation between sedimentary basins of the United Nations ESCAP region): United Nations ESCAP, Mineral Resources Development Series, no. 44, v. 5, p 13-31.

Bachman, S.B., Lewis, S.D., and Schweller, W.J., 1983, Evolution of a forearc basin, Luzon Central Valley, Philippines: American Association of Petroleum Geologists Bulletin, v. 67, p. 1143-1162.

Beaudry, D., and Moore, G.F., 1981, Seismic-stratigraphic framework of the forearc basin off central Sumatra, Sunda Arc: Earth and Planetary Science Letters, v. 54, p. 17-28.

Beaudry, D., and Moore, G.F., 1985, Seismic stratigraphy and Cenozoic evolution of West Sumatra Forearc Basin: American Association of Petroleum Geologists Bulletin, v. 69 , no. 5 , p. $742-759$.

Bender, F., Bannert, D., Brinckmann, J., Gramann, F., and Helmcke, D., 1983, Geology of Burma: Berlin, Gebrueder Borntraeger, $293 \mathrm{p}$.

Bersenev, I.I., Bezverkhnii, V.L., Vashchenkova, N.G., Gororaya, M.T., and Tsoi, I.B., 1985, Miocene stratigraphy of the shelf and continental slope of the maritime territory (Sea of Japan), in Geology of the Pacific Ocean: United Kingdom, Harwood Academic Publishers, v. 3, p. 291-304.

Bickel, R.S., 1976, Cape Vogel Basin, in Leslie, R.B., Evans, H.J., and Knight, C.L., eds., Economic geology of Australia and Papua New Guinea-part 3, Petroleum: Australasian Institute of Mining and Metallurgy Monograph Series, no. 7, p. 506-513.

Bhandari, L.L., Fuloria, R.C., and Sastri, V.V., 1973, Stratigraphy of Assam Valley, India: American Association of Petroleum Geologists Bulletin, v. 57, p. 642-654.

Bikkenina, S.K., and Argentov, V.V., 1985, A seismogeologic model for the eastern part of central and south Sakhalin, in Geology of the Pacific Ocean: United Kingdom, Harwood Academic Publishers, v. 3, p. 114-125.

Bol, A.J., and van Hoorn, B., 1980, Structural style in western Sabah offshore: Geological Society of Malaysia Bulletin, no. 12, p. 1-16.

Bomasang, R.B., 1988, The potential for the use of coal and peat in small-scale industries and rural households in countries with dispersed coal deposits: Regional Energy Development Programme (RAS/84/001), United Nations Development Programme, and United Nations Economic and Social Commission for Asia and the Pacific (ESCAP), $226 \mathrm{p}$. 
Branagan, D.F., 1975, Distribution and geological setting of coal measures in Australia and Papua New Guinea, in Traves, D. M., King, D., and Knight, C.L., eds., Economic geology of Australia and Papua New Guinea-part 2, Coal: Australasian Institute of Mining and Metallurgy Monograph Series, no. 6, p. 25-51.

Bureau of Mines and Geo-sciences, Ministry of Natural Resources, 1982, Geology and mineral resources of the Philippines-geology: Manila, Bureau of Mines and Geo-sciences, v. 1, $406 \mathrm{p}$.

- 1986, Geology and mineral resources of the Philippinesmineral resources: Manila, Bureau of Mines and Geosciences, v. 2, 446 p.

Carmalt, S.W., and St. John, Bill, 1986, Giant oil and gas fields, in Halbouty, M.T., ed., Future petroleum provinces of the world, Proceedings of the Wallace E. Pratt Memorial Conference, Phoenix, Arizona, December 1984: American Association of Petroleum Geologists, Memoir 40, p. 11-53.

Chen, Huanjiang, Sun, Z., and Zhang, Y., 1986, The framework of Chinese petroliferous basins: Journal of Petroleum Geology, v. 9, p. 451-462.

Chen, Shick Pei, 1986, Coal potential and exploration in Sarawak, in Congress on Geology, Mineral, and Energy Resources of Southeast Asia (GEOSEA), 5th, Proceedings-Volume II: Geological Society of Malaysia Bulletin, no. 20, p. 649-665.

Chen, Q., and Dickinson, W., 1986, Contrasting nature of petroliferous Mesozoic-Cenozoic basins in eastern and western China: American Association of Petroleum Geologists Bulletin, v. 70, p. 263-275.

Chin, C., 1980, Non-marine setting of petroleum in the Sungliao Basin of northeastern China: Journal of Petroleum Geology, v. 2, no. 3, p. 233-264.

Chingchang, B., Shyu, C.T., Chen, J.C., and Boggs, S., Jr., 1985, Taiwan-geology, geophysics and marine sediments, in Nairn, A.E., Stehli, F.G., and Uyeda, S., eds., The Pacific Ocean, v. 7A of The ocean basins and margins: New York, Plenum Press, p. 503-550.

Choi, H.I., and Park, K.S., 1985, Cretaceous/Neogene stratigraphic transition and post Gyeongsang evolution along and off the southeast coast, Korea: The Journal of the Geological Society of Korea, v. 21, no. 4, p. 81-296.

Chou, J.T., 1980, Stratigraphy and sedimentology of the Miocene in western Taiwan: Petroleum Geology of Taiwan, no. 17 , p. $33-52$.

Chu, C., 1985, Hengyang Basin, in United Nations Economic and Social Commission for Asia and the Pacific (ESCAP), Atlas of stratigraphy, Republic of China (Stratigraphic correlation between sedimentary basins of the United Nations ESCAP region, v. 10): United Nations ESCAP, Mineral Resources Development Series, no. 52, p. 35-38.

Churkin, M., Jr., Soleimani, G., Carter, C., and Robinson, R., 1981, Geology of the Soviet Arctic-Kola Peninsula to Lena River, in Nairn, A.E., and others, eds., The Arctic Ocean, v. 5 of The ocean basins and margins: New York, Plenum Press, p. 331-375.

Churkin, M., Jr., 1983, Tectonostratigraphic terranes of Alaska and northern U.S.S.R. - A record of collision and accre- tion, in Hashimoto, M., and Uyeda, S., eds., Accretion tectonics in the circum-Pacific regions: Tokyo, Terra Scientific Publishing Company, p. 37-42.

Clarke, J.W., 1985, Petroleum geology of East Siberia: U.S. Geological Survey Open-File Report 85-367, 123 p.

- 1988, Sedimentary basins of northeastern U.S.S.R.: U.S. Geological Survey Open-File Report 88-264, 59 p.

Coulson, F.I., 1985, Solomon Islands, in Nairn, A.E., Stehli, F.G., and Uyeda, S., eds., The Pacific Ocean, v. 7A of The ocean basins and margins: New York, Plenum Press, p. 607-682.

Curray, J.R., Emmel, F.J., Moore, D.G., and Raitt, R.W., 1982, Structure, tectonics, and geological history of the northeastern Indian Ocean, in Nairn, A.E., and Stehli, F.G., eds., The Indian Ocean, v. 6 of The ocean basins and margins: New York, Plenum Press, p. 399-450.

Datuin, R.T., and Troncales, A.C., 1986, Philippine geothermal resources, general geological setting and development: Geothermics, v. 15, p. 613-622.

DiPippo, R., 1987, Geothermal power generation from liquiddominated resources: Geothermal Science and Technology, v. 1, p. 63-124.

Dorian, J., Clark, A., Sun, Y., Zhou, Z., and Li, J., 1988, Mineral resources of China-apparent controls on distribution: Geojournal, v. 17, p. 373-388.

Dow, D.B., Robinson, G.P., and Ratman, N., 1985, New hypothesis for formation of Lengguru Fold Belt, Irian Jaya, Indonesia: American Association of Petroleum Geologists Bulletin, v. 69, p. 203-214.

Drummond, K.J., 1986, Energy-resources map of the circumPacific region, northeast quadrant: Houston, Tex., CircumPacific Council for Energy and Mineral Resources, 72 p., scale $1: 10,000,000$.

Duncan, D.C., 1976, Geologic setting of oil-shale deposits and world prospects, in Yen, T.F., and Chilingarian, G.V., eds., Oil shale (Developments in Petroleum Science 5): Amsterdam, Elsevier, p.13-26.

Duncan, D.C., and Swanson, V.E., 1965, Organic-rich shale of the United States and world land areas: United States Geological Survey Circular 523, 30 p.

Du Bois, E.P., 1985, Review of principal hydrocarbon-bearing basins around the South China Sea: Geological Society of Malaysia Bulletin, no. 18, p. 167-209.

Eremenko, N.A., Krasny, L.I., and Fedinsky, V.V., 1978, Petroleum coal map of Pacific mobile belt and ocean: Soviet Science Academy, U.S.S.R. Ministry of Oil Industry, U.S.S.R. Ministry of Geology, and U.S.S.R. Ministry of Education, scale 1:10,000,000.

Fulthorpe, C.S., and Schlanger, S.O., 1989, Paleo-oceanographic and tectonic setting of early Miocene reefs and associated carbonates of offshore Southeast Asia: American Association of Petroleum Geologists Bulletin, v. 73, p. 729-756.

Gayduk, V.V., 1987, The Middle Paleozoic Vilyuy rift system: Geotectonics, v. 21, p. 247-255.

Geology Department of the Indonesian State Oil and Gas Enterprise (PERTAMINA), 1974, Tertiary basins in Indonesia: United Nations Economic and Social Commission 
for Asia and the Pacific (ESCAP), Committee for Coordination of Joint Prospecting for Mineral Resources in East Asian Offshore Areas (CCOP), Technical Bulletin, v. 8, p. 71-72.

Geological Survey of Japan, 1987, Hot springs distribution map of northern Thailand: Miscellaneous Map Series, no. 25, scale $1: 1,000,000$.

Gibling, M.R., and Ratanasthien, B., 1980, Cenozoic basins of Thailand and their coal deposits, a preliminary report: Geological Society of Malaysia Bulletin, no. 13, p. $27-42$.

Gibling, M.R., Tanitisukrit, C., Uttamo, W., Thanasuthipitak, T., and Haraluck, M., 1985, Oil shale sedimentology and geochemistry in Cenozoic Mae Sot Basin, Thailand: American Association of Petroleum Geologists Bulletin, v. 69 , no. 5 , p. $767-780$.

Gibling, M.R., Ukakimaphan, Y., and Srisuk, S., 1985, Oil shale and coal in intermontane basins of Thailand: American Association of Petroleum Geologists Bulletin, v. 69, no. 5, p. $760-766$.

Gnibidenko, H.S., 1985, The sea of Okhotsk-Kurile Islands Ridge and Kurile-Kamchatka Trench, in Nairn, A.E., Stehli, F.G., and Uyeda, S., eds., The Pacific Ocean, v. 7A of The ocean basins and margins: New York, Plenum Press, p. 377-418.

Gonzales, B.A., Martin, S.G., 1978, Onshore stratigraphy of Philippines, in United Nations Economic and Social Commission for Asia and the Pacific (ESCAP), Atlas of stratigraphy I, Burma, Malaysia,Thailand, Indonesia, Philippines (Stratigraphic correlation between sedimentary basins of the United Nations ESCAP region, v. 5): United Nations ESCAP, Mineral Resources Development Series, no. 44 , p. 33-44.

Grunau, H.R., and Gruner, U., 1978, Source rocks and the origin of natural gas in the Far East: Journal of Petroleum Geology, v. 1, no. 2, p. 3-56.

Grund, R.B., 1976, North New Guinea Basin, in Leslie, R.B., Evans, H.J., and Knight, C.L., eds., Economic geology of Australia and Papua New Guinea-part 3, Petroleum: Australasian Institute of Mining and Metallurgy Monograph Series, no. 7, p. 499-506.

Guan, S., Yuan, J., Wang, S., Xu, M., Yuan, F., Chen, X., and Jiang, S., 1985, Meso-Cenozoic basins of continental facies of China, in United Nations Economic and Social Commission for Asia and the Pacific (ESCAP), Atlas of stratigraphy, Republic of China (Stratigraphic correlation between sedimentary basins of the United Nations ESCAP region, v. 10): United Nations ESCAP, Mineral Resources Development Series, no. 52, p. 1-12.

Gupta, H.K., 1980, Geothermal resources: an energy alternative: Amsterdam, Elsevier, 227 p.

Hamilton, Warren, 1979, Tectonics of the Indonesian region: U.S. Geological Survey Professional Paper 1078, 345 p.

- 1988, Plate tectonics and island arcs: Geological Society of America Bulletin, v. 100, p. 1503-1527.

Hayashi, M., 1988, The hydrocarbon potential and tectonics of Indochina: Journal of Petroleum Geology, v. 11, p. 219-232.

Hirayama, J., Sumii, T., and Watanabe, Y., 1989 MS, Sedimentary basin map of Japan and surrounding area: scale $1: 2,000,000$.
Ho, Kiam Fui, 1978, Stratigraphic framework for oil exploration in Sarawak: Geological Society of Malaysia Bulletin, no. 10, p. 1-13.

Honza, E., ed., 1976, Ryukyu Island (Nansei-Shoto) Arc, GH 75-1 and GH 75-5 Cruises, January-February and JulyAugust, 1975: Geological Survey of Japan Cruise Report, no. $6,81 \mathrm{p}$.

- 1977, Geological investigation of Japan and Southern Kurile trench and slope areas, GH 76-2 Cruise, April-June 1976: Geological Survey of Japan Cruise Report, no. 7, 127 p.

-1978 , Geological investigations in the northern margin of the Okinawa Trough and the western margin of the Japan Sea, GH 77-2 Cruise, April-May 1977: Geological Survey of Japan Cruise Report, no. 10, 79 p.

- 1978, Geological investigation of the Okhotsk and Japan Seas off Hokkaido, GH 77-3 Cruise, June-July 1977: Geological Survey of Japan Cruise Report, no. 11, 72 p.

- 1979, Geological investigation of the Japan Sea, GH 78-2 Cruise, April-June 1978: Geological Survey of Japan Cruise Report, no. 13,99 p.

- 1984, Geological investigation of the junction area of the Tohoku and Ogasawara Arcs, GH 80-2 and GH 80-3 Cruises, April-June 1980: Geological Survey of Japan Cruise Report, no. 19, 130 p.

Honza, E., and Tamaki, K., 1985, The Bonin Arc, in Nairn, A.E., Stehli, F.G., and Uyeda, S., eds., The Pacific Ocean, v. 7A of The ocean basins and margins: New York, Plenum Press, p. 459-502.

Hutchison, C.S., 1989, Geological evolution of southeast Asia: Oxford, Oxford University Press, 368 p.

Hughes, G.W., and Turner, C.C., 1977, Upraised Pacific Ocean floor, southern -Malaita, Solomon Islands: Geological Society of America Bulletin, v. 88, p. 412-424.

Ikebe, N., and Tsuchi, R., eds., 1984, Pacific Neogene datum planes, contributions to biostratigraphy and chronology: Tokyo, University of Tokyo Press, 288 p.

Indonesian Association of Geologists, 1980, The energy resources map of Indonesia: Indonesian Association of Geologists, scale 1:5,000,000.

Inoma, A., 1984, Petroleum geological features and technical problems related to hydrocarbon exploration in Japangeological problems in island arc systems: Geological Survey of Japan Report, no. 263, p. 127-139.

Inoue, Eiji, ed., 1975, Goto-Nada Sea and Tsushima Strait investigations, northwestern Kyushu, 1972-1973: Geological Survey of Japan Cruise Report, no. 2, 68 p.

- 1975, Sagami-Nada Sea investigations, GH 74-1 and GH 75-2 Cruises, April-May 1974: Geological Survey of Japan Cruise Report, no. 3, 58 p.

- 1978, Investigation of the continental margin of southwest Japan, GH 75-4 Cruise, June-July 1975: Geological Survey of Japan Cruise Report, no. 9, 88 p.

Inoue, Eiji, 1988, Geologic map of the circum-Pacific region, northwest quadrant: Houston, Tex., Circum-Pacific Council for Energy and Mineral Resources, 30 p., scale $1: 10,000,000$.

Institute of Geology, Chinese Academy of Geological Science, Wuhan College of Geology, 1985, Atlas of the palaeogeography of China: Beijing, Cartographic Publishing House, 294 p. 
Institute of Geomechanics, Chinese Academy of Geological Science, 1984, Tectonic systems map of the People's Republic of China and adjacent sea area: Beijing, Cartographic Publishing House, scale 1:2,500,000.

Ishiwada, Y., and Ogawa, K., 1976, Petroleum geology of offshore areas around the Japanese Islands, in United Nations Economic and Social Commission for Asia and the Pacific (ESCAP), Committee for Coordination of Joint Prospecting for Mineral Resources in East Asian Offshore Areas (CCOP), Technical Bulletin: v. 10, p. 23-34.

Ishiwada, Y., Honza, E., and Tamaki, K., 1984, Sedimentary basins of the Japan Sea: International Geological Congress, 27th, Proceedings: v. 23, p. 43-65.

Jia, R.S., Huang, Y.Y., Ye, D.S., and Zhong, H.M., 1985, Chaidamu Basin, in United Nations Economic and Social Commission for Asia and the Pacific (ESCAP), Atlas of stratigraphy, Republic of China (Stratigraphic correlation between sedimentary basins of the United Nations ESCAP region, $v$. 10): United Nations ESCAP, Mineral Resources Development Series, no. 52, p. 75-81.

Jin, X., and Yu, P., 1988, Structure and tectonic evolution of Okinawa Trough: Scientia Sinica (Series B), v. 31, p. 614623.

Katz, H.R., 1980, Basin development in the Solomon Islands and their petroleum potential: United Nations Economic and Social Commission for Asia and the Pacific (ESCAP), Committee for Coordination of Joint Prospecting for Mineral Resources in South Pacific Offshore Areas (CCOP) Technical Bulletin, v. 3, p. 59-75.

- 1986, Stratigraphy of the southwest Pacific, in Cronan, D.S., ed., Sedimentation and mineral deposits in the southwestern Pacific Ocean: London, Academic Press, p. 4-82.

- 1986, Hydrocarbon potential in the southwest Pacific, in Cronan, D.S., ed., Sedimentation and mineral deposits in the southwestern Pacific Ocean: London, Academic Press, p. 83-116.

Ke, R., and Pigott, J.D., 1986, Episodic rifting and subsidence in the South China Sea: American Association of Petroleum Geologists Bulletin, v. 70, no. 9, p. 1136-1155.

Khain, V.E., 1985, Geology of the U.S.S.R-part I, Old cratons and Paleozoic fold belts: Berlin-Stuttgart, Gebrueder House, 272 p.

Khan, M.A.M., and Husain, M., 1980, A look at the geology of Bangladesh gas field: Oil and Gas Journal, v. 78, no. 31 (August 4, 1980), p. 92-95.

Khan, M.A.M., 1980, Bangladesh: A brief account on geology and hydrocarbon exploration: Oil and Gas Journal, v. 78, no. 28 (July 14, 1980), p. 182-186.

Kimbara, K., 1988, Geothermal resources in Japan-geothermal fields and geothermal power plants in Japan: International Symposium on Geothermal Energy, Kumamoto and Beppu, Japan, 1988.

Kingston, J., 1986, Undiscovered petroleum resources of South Asia: U.S. Geological Survey Open-File Report 86-80, $172 \mathrm{p}$.

- 1988, Undiscovered petroleum resources of Indonesia : U.S. Geological Survey Open-File Report 88-379, 217 p.

Kobayashi, K., 1985, Sea of Japan and Okinawa Trough, in Nairn, A.E., Stehli, F.G., and Uyeda, S., eds., The Pacific
Ocean, v. 7A of The ocean basins and margins: New York, Plenum Press, p. 419-458.

Kodar, D.S., and Siregar, S., 1978, Onshore sedimentary basins of Indonesia, in United Nations Economic and Social Commission for Asia and the Pacific (ESCAP), Atlas of stratigraphy I, Burma, Malaysia, Thailand, Indonesia, Philippines (Stratigraphic correlation between sedimentary basins of the United Nations ESCAP region, $v$. 5): United Nations ESCAP, Mineral Resources Development Series, no. 44, p. 11-12.

Kononov, V.E., Lopatnev, Y.V., Sludnev, Y.G., and Kharakhinov, V.V., 1987, Seismic stratigraphy in oil and gas exploration in north Sakhalin, in Geology of the Pacific Ocean: United Kingdom, Harwood Academic Publishing, v. 3, p. 935-944.

Kouno, M., ed., 1980, Japan, in United Nations Economic and Social Commission for Asia and the Pacific (ESCAP), Atlas of stratigraphy (Stratigraphic correlation between sedimentary basins of the United Nations ESCAP region, v. 6): United Nations ESCAP, Mineral Resources Development Series, no. 46, p. 61-108.

Kosygin, Y.A., and Parfenov, L.M., 1981, Tectonics of the Soviet Far East, in Nairn, A.E., and others, eds., The Arctic Ocean, v. 5 of The ocean basins and margins: New York, Plenum Press, p. 377-412.

Kuang, M.Y., and Wu, S.C.S., 1986, Hydrocarbon potential in western Taiwan: Chinese Petroleum Institute in cooperation with Chinese Petroleum Corporation, Petroleum Geology of Taiwan, no. 22, p. 201-226.

Le, Van Khy, 1986, The structure of the Mekong Trough: Geology Review, v. 28, p. 87-95.

Lee, D.S., ed., 1987, Geology of Korea: Seoul, Geological Society of Korea, 314 p.

Lee, K.Y., 1984, Geology of the Chaidamu Basin, Qinghai Province, north China: U.S. Geological Survey Open-File Report 84-413, 44 p.

-1984, Geology of the Dian-Qian-Gui Foldbelt, southwest China: U.S. Geological Survey Open-File Report 84-357, 73 p.

- 1985, Geology of the petroleum and coal deposits in the Junggar (Zhungaer) Basin, Xinjiang Uygur Zizhiqu, northwest China: U.S. Geological Survey Open-File Report 85-230, $53 \mathrm{p}$.

- 1985, Geology of the Tarim Basin with special emphasis of petroleum deposits, Xinjiang Uygur Zizhiqu, northwest China: U.S. Geological Survey Open-File Report 85-616, 55 p.

- 1986, Geology of the coal and petroleum deposits in the Ordos Basin, China: U.S. Geological Survey Open-File Report 86-278, 63 p.

- 1986, Petroleum geology of the Songliao Basin, northeast China: U.S. Geological Survey Open-File Report 86-502, $19 \mathrm{p}$.

- 1989, Geology of petroleum and coal deposits in the North China Basin, eastern China: U.S. Geological Survey Bulletin $1871,36 \mathrm{p}$.

Lee, K.Y., and Masters, C.D., 1988, Geologic framework, petroleum potential, and field locations of the sedimentary basins in China: U.S. Geological Survey Miscellaneous Investigations Series Map I-1952, scale 1:5,000,000. 
Lewis, S. D., and Hayes, D. E., 1984, A geophysical study of the Manila trench, Luzon, Philippines, part 2-forearc basin structural and stratigraphic evolution: Journal of Geophysical Research, v. 89, no. B11, p. 9196-9214.

Li, C., 1982, Tectonic map of Asia: Research Institute of Geology, Chinese Academy of Geological Science, scale 1:8,000,000.

Li, D., 1984, Geologic evolution of petroliferous basins on the continental shelf of China: American Association of Petroleum Geologists Bulletin, v. 68, no. 8, p. 993-1003.

- 1987, Geological characteristics of hydrocarbon generation and distribution in the Songliao Basin, China, in Kumar, R.K., and others, eds., Petroleum geochemistry and exploration in the Afro-Asian region: International Conference on Petroleum Geochemistry and Exploration in the Afro-Asian Region, 1st, Dehradun, 1985, Proceedings: Rotterdam, Balkema, p. 191-195.

Li, J., and Tang, Z., 1985, Sanshui Basin, in United Nations Economic and Social Commission for Asia and the $\mathrm{Pa}$ cific (ESCAP), Atlas of stratigraphy, Republic of China (Stratigraphic correlation between sedimentary basins of the United Nations ESCAP region, v. 10): United Nations ESCAP, Mineral Resources Development Series, no. 52 , p. $39-44$.

Li, L., 1985, Eerdosi Basin, in United Nations Economic and Social Commission for Asia and the Pacific (ESCAP), Atlas of stratigraphy, Republic of China (Stratigraphic correlation between sedimentary basins of the United Nations ESCAP region, v. 10): United Nations ESCAP, Mineral Resources Development Series, no. 52, p. 53-62.

Liu, H., 1986, Geodynamic scenario and structural styles of Mesozoic and Cenozoic basins in China: American Association of Petroleum Geologists Bulletin, v. 70, p. 377-395.

Ludwig, W.J., and Houtz, R.E., 1979, Isopach map of sediments in the Pacific Ocean basin and marginal sea basins: American Association of Petroleum Geologists, scale $1: 13,999,369$.

Ma, L., 1985, Subtle oil pools in Xingshugang delta, Songliao Basin: American Association of Petroleum Geologists Bulletin, v. 69, no. 7, p. 1123-1132.

Mainguy, M., 1969, Regional geology and petroleum prospects of the marine shelves of eastern Asia: United Nations Economic Commission for Asia and the Far East (ECAFE), Committee for Coordination of Joint Prospecting for Mineral Resources in East Asian Offshore Areas (CCOP), Technical Bulletin, v. 3, p. 91-107.

Maruyama, S., Liou, J.G., and Seno, T., 1988, Mesozoic and Cenozoic evolution of Asia, in Ben-Avraham, Z., ed., The evolution of the Pacific Ocean margins: Oxford University Press, Oxford Monographs on Geology and Geophysics, no. 13, p. 75-99.

Meyerhoff, A.A., 1970, Developments in mainland China, 1949-1968: American Association of Petroleum Geologists, v. 54 , no. 8 , p. 1567-1580.

-1981, The oil and gas potential of the Soviet Far East: Beaconsfield, United Kingdom, Scientific Press Ltd., 176 p.

Meyerhoff, A.A., and Willums, J.O., 1976, Petroleum geology and industry of the People's Republic of China: United Nations Economic and Social Commission for Asia and the Pacific (ESCAP), Committee for Coordination of Joint Prospecting for Mineral Resources in East Asian Offshore Areas (CCOP), Technical Bulletin, v. 10, p. 103-212.

Milson, J., 1985, New Guinea and the Western Melanesian Arcs, in Nairn A.E., Stehli, F.G., and Uyeda, S., eds., The Pacific Ocean, v. 7A of The ocean basins and margins: New York, Plenum Press, p. 551-601.

Miyazaki, H., Ikebe, Y., and Ukai, M., 1980, Some aspects of reservoir characteristics in Japanese oil and gas fields, with special reference to their depositional environments: United Nations Economic and Social Commission for Asia and the Pacific (ESCAP), Committee for Coordination of Joint Prospecting for Mineral Resources in South Pacific Offshore Areas (CCOP/SOPAC), Technical Bulletin, v. 3, p. 59-75.

Moore, G.W., 1987, Plate perimeters and motion vectors, in Inoue, Eiji, Plate-tectonic map of the circum-Pacific region, northwest quadrant: Houston, Tex., Circum-Pacific Council for Energy and Mineral-Resources, 14 p., scale $1: 10,000,000$.

Murphy, R.W., and others, 1988, Bangladesh enters the oil era: Oil and Gas Journal, v. 86, no. 9 (February 29, 1988), p. 76-82.

Nishiwaki, Chikao, 1977, Geographic map of the circum-Pacific region, northwest quadrant: Tulsa, Okla., American Association of Petroleum Geologists, scale 1:10,000,000.

- 1981, Plate-tectonic map of the circum-Pacific region, northwest quadrant: Tulsa, Okla., American Association of Petroleum Geologists, 14 p., scale 1:10,000,000; revised by Inoue, Eiji, 1987.

- 1985, Geodynamic map of the circum-Pacific region, northwest quadrant: Houston, Tex., Circum-Pacific Council for Energy and Mineral Resources, 12 p., scale 1:10,000,000.

Office of the Project Manager/Co-ordinator, United Nations Development Programme Technical Support for Regional Offshore Prospecting in East Asia, 1977, The offshore hydrocarbon potential of East Asia-A decade of investigations (1966-1975): United Nations Economic and Social Commission for Asia and the Pacific (ESCAP), Committee for Coordination of Joint Prospecting for Mineral Resources in East Asian Offshore Areas (CCOP), Technical Bulletin, v. 11, p. 1-68.

Oil and Gas Journal, 1987, Big strikes elude Soviet exploration in eastern Siberia: v. 85, no. 9 (March 2, 1987), p. 15-17.

- 1991, Worldwide production: v. 89, no. 52 (December 30 , 1991), p. 50-88.

Okuda, Y., 1984, Tectonic evolution of the continental margin off southwest Japan during the late Cenozoic: Report of the Technology Research Center, Japan National Oil Corporation, no. 19.

Ooi, Jin Bee, 1982, The petroleum resources of Indonesia: Kuala Lumpur, Oxford University Press, 256 p.

Orasianu, T., and Craig, G., 1987, Offshore Burma-exploration hydrocarbon habitat: Oil and Gas Journal, v. 85, no. 3 (January 19, 1987), p. 62-65.

Oudin, J.L., 1987, Source rock and hydrocarbon generation in the Beibu Gulf, south China, in Kumar, R.K., and others, eds., Petroleum geochemistry and exploration in the Afro- 
Asian region, International Conference on Petroleum Geochemistry and Exploration in the Afro-Asian Region, 1st, Dehradun, 1985, Proceedings: Rotterdam, Balkema, p. 181-190.

Parker, E.S., and Gealey, W.K., 1985, Plate-tectonic evolution of the western Pacific-Indian Ocean region: Energy, v. 10 , no. $3 / 4$, p. $249-261$.

Penwell Publishing Co., Energy Group, 1991, International petroleum encyclopedia: Tulsa, Okla., Penwell Publishing Co., v. 24, 368 p.

Petzet, G.A., 1990, Mongolia set to beckon foreign operators: Oil and Gas Journal, v. 88, no. 47 (November 19, 1990), p. 27-28.

Philippine Bureau of Mines, Mineral Fuels Division, 1976, A review of oil exploration and stratigraphy of sedimentary basin of the Philippines: United Nations Economic and Social Commission for Asia and the Pacific (ESCAP), Committee for Coordination of Joint Prospecting for Mineral Resources in East Asian Offshore Areas (CCOP), Technical Bulletin, v. 10, p. 55-102.

Pitakpaivan, K., and Chonglakmani, C., 1978, Continental Mesozoic basins of Thailand, in United Nations Economic and Social Commission for Asia and the Pacific (ESCAP), Atlas of stratigraphy I, Burma, Malaysia, Thailand, Indonesia, Philippines (Stratigraphic correlation between sedimentary basins of the United Nations ESCAP region, v. 5): United Nations ESCAP, Mineral Resources Development Series, no. 44, p. 45-50.

Ridd, M.F., 1976, Papuan Basin-onshore, in Leslie, R.B., Evans, H.J., and Knight, C.L., eds., Economic geology of Australia and Papua New Guinea-part 3, Petroleum: Australasian Institute of Mining and Metallurgy Monograph Series, no. 7, p. 478-494.

Rijks, E.J.H., 1981, Baram Delta geology and hydrocarbon occurrence: Geological Society of Malaysia Bulletin, no. 14, p. 1-18.

Riva, J.P., Jr., 1983, Assessment of undiscovered conventionally recoverable petroleum resources of Indonesia: U.S. Geological Survey Circular 899, 17 p.

Robinson, K., 1984, Assessment of undiscovered conventionally recoverable petroleum resources in Tertiary sedimentary basins of Thailand: U.S. Geological Survey OpenFile Report 84-330, 14 p.

- 1984, Assessment of undiscovered con-ventionally recoverable petroleum resources in offshore Tertiary sedimentary basins of the People's Republic of China: U.S. Geological Survey Open-File Report 84-329, 13 p.

- 1985, Assessment of undiscovered con-ventionally recoverable petroleum resources in Tertiary basins of Malaysia and Brunei: Geological Society of Malaysia Bulletin, no. 18, p. $119-131$.

St. John, B., 1984, Sedimentary provinces of the world-hydrocarbon productive and non-productive: American Association of Petroleum Geologists, scale 1:31,368,000.

Saldivar-Sali, A., Oesterle, H.G., and Brownlee, D.N., 1981, Geology of offshore northwest Palawan, Philippines-1: Oil and Gas Journal, v. 79, no. 48 (November 30, 1981), p. 119-128.
- 1981, Geology of offshore northwest Palawan, Philippines2: Oil and Gas Journal, v. 79, no. 49 (December 7, 1981), p. 234-242.

- 1981, Geology of offshore northwest Palawan, Philippines3: Oil and Gas Journal, v. 79, no. 50 (December 14, 1981), p. 196-199.

Sattayarak, N., 1983, Review of the continental Mesozoic stratigraphy of Thailand: Proceedings of the Workshop on Stratigraphic Correlation of Thailand and Malaysia, p. 127-148.

Sergeev, K.F., 1985, New data on the relationship between upper Mesozoic and Cenozoic strata on the eastern sides of the West Sakhalin Mountains (Makavov District, Sakhalin), in Geology of the Pacific Ocean: United Kingdom, Harwood Academic Publishers, v. 3, p. 161-170.

Spencer, F.D., and Vergara, J.F., 1957, Coal resources of the Philippines: Philippines Bureau of Mines, Special Project Set, No. 20-Coal, 52 p.

Stewart, W.D., and Durkee, E.F., 1985, Petroleum potential of the Papuan basin: Oil and Gas Journal, v. 83, no. 13, (April 1, 1985), p. 151-160.

Stewart, W.D., Francis, G., and Pederson, S.L., 1987, Hydrocarbon potential of Papua New Guinea's Bougainville, southeastern New Ireland basins: Oil and Gas Journal, v. 85 , no. 47 (November 23, 1987), p. 83-87.

Sun, S., Li, J., Chen, H., Peng, H., Hsue, K.J., and Shelton, J.W., 1989, Mesozoic and Cenozoic sedimentary history of South China: American Association of Petroleum Geologists Bulletin, v. 73, no. 10, p. 1247-1269.

Taira, A., and Tashiro, M., 1987, Historical biogeography and plate-tectonic evolution of Japan and eastern Asia: Tokyo, Terra Scientific Publishing Company, 221 p.

Tamaki, K., 1988, Geological structure of the Japan Sea and its tectonic implications: Bulletin of the Geological Survey of Japan, v. 39, no. 5, p. 269-365.

Tapponnier, P., and Molnar, P., 1977, Active faulting and tectonics in China: Journal of Geophysical Research, v. 82, p. 2905-2930.

Tarner, I., Kamen-kaye, M., and Meyerhoff, A.A., 1988, Petroleum in the Jungger Basin, northwestern China: Journal of Southeast Asian Earth Sciences, v. 2, p. 163-174.

Tatsch, J.H., 1980, Coal deposits-origin, evolution, and present characteristics: Sudbury, Mass., Tatsch Associates, 590 p.

Taylor, B., and Hayes, D.E., 1980, The tectonic evolution of the South China Basin, in Hayes, D.E., ed., The tectonic and geologic evolution of Southeast Asian seas and islands: American Geophysical Union Geophysical Monograph 23, p. 89-104.

Taylor, B., and Hayes, D.E., 1983, Origin and history of the South China Basin, in Hayes, D.E., ed., The tectonic and geologic evolution of Southeast Asian seas and islandspart 2: American Geophysical Union Geophysical Mono-. graph 27, p. 23-56.

Technical Committee of Association of Southeast Asian Nations Council on Petroleum (ASCOPE), 1981, Tertiary sedimentary basins of the Gulf of Thailand and South China Sea-stratigraphy, structure and hydrocarbon occurrences: Association of Southeast Asian Nations Council on Petroleum (ASCOPE), 72 p. 
Technical Secretariat of Committee for Coordination of Joint Prospecting for Mineral Resources in East Asian Offshore Areas (CCOP), 1972, Explanatory notes to accompany the map-Tertiary basins of eastern Asia and their offshore extensions (revised April 1971): United Nations Economic Commission for Asia and the Far East (ECAFE), Committee for Coordination of Joint Prospecting for Mineral Resources in East Asian Offshore Areas (CCOP), Technical Bulletin, v. 6, p. 225-227.

Thein, M.L., Nyunt, T., and Saing, C., 1978, Onshore sedimentary basins of Burma, in United Nations Economic and Social Commission for Asia and the Pacific (ESCAP), Atlas of stratigraphy I, Burma, Malaysia, Thailand, Indonesia, Philippines (Stratigraphic correlation between sedimentary basins of the United Nations ESCAP region, v. 5): United Nations ESCAP, Mineral Resources Development Series, no. 44, p. 1-10.

Thomas, L.P., and Park, S.W., 1976, Investigation of the geology of the coalfields of Korea: Korea Research Institute of Geoscience and Mineral Resources, 82 p.

Tiratsoo, E.N., 1984, Oilfields of the world: Beaconsfield, United Kingdom, Scientific Press Ltd., 392 p.

Tono, S., 1975, A review of the oil and gas potential of Far East Asia-onshore and offshore: Geology and paleontology of Southeast Asia, v. 15, p. 419-461.

Tsuchi, R., ed., 1981, Neogene of Japan-its biostratigraphy and chronology: International Geological Correlation Program (IGCP)-114, National Working Group of Japan.

United Nations Economic and Social Commission for Asia and the Pacific (ESCAP), 1985, Oil and natural gas map of Asia ( $3 d$ ed.): scale 1:5,000,000.

Wang, S., Hu, W., and Tan, S., 1982, Habitat of oil and gas fields in China: Oil and Gas Journal, v. 80, no. 24 (June 14, 1982), p. 119-128.

Waring, G.A., 1965, Thermal springs of the United States and other countries of the world: U.S. Geological Survey Professional Paper 492, 383 p.

Watson, M.P., Hayward, A.B., Parkinson, D.N., and Zhang, Z.M., 1987, Plate-tectonic history, basin development and petroleum source rock deposition onshore China: Marine and Petroleum Geology, v. 4, p. 205-225.

Wise, R.A., 1976, Papuan Basin-offshore, in Leslie, R.B., Evans, H.J., and Knight, C.L., eds., Economic geology of Australia and Papua New Guinea-part 3, Petroleum: Australasian Institute of Mining and Metallurgy Monograph Series, no. 7, p. 494-499.

Wood, P.W.J., 1980, Hydrocarbon plays in Tertiary Southeast Asia basins: Oil and Gas Journal, v. 78, no. 29 (July 21, 1980), p. 90-96.

Woodside, P.R., 1984, A look at the petroleum geology of Indonesia: Oil and Gas Journal, v. 82, no. 8 (February 20, 1984), p. 78-82.

World Coal Resources and Reserves Data Bank Service, 1983, Concise guide to world coalfields: International Energy Agency Coal Research.

Xu, C., 1985, Chaidamu Basin, in United Nations Economic and Social Commission for Asia and the Pacific (ESCAP), Atlas of stratigraphy, Republic of China (Stratigraphic correlation between sedimentary basins of the United Nations ESCAP region, v. 10): United Nations ESCAP, Mineral Resources Development Series, no. 52, p. 70-74.

Yang, W., 1985, Daqing oil field, People's Republic of Chinaa giant field with oil of nonmarine origin: American Association of Petroleum Geologists Bulletin, v. 69, p. 1101 1111.

Yang, W., Li, Y., and Gao, R., 1985, Formation of nonmarine petroleum in Songliao Basin, China: American Association of Petroleum Geologists Bulletin, v. 69, p. 1112-1122.

Yin, J., 1985, Sichuan Basin, in United Nations Economic and Social Commission for Asia and the Pacific (ESCAP), Atlas of stratigraphy, Republic of China (Stratigraphic correlation between sedimentary basins of the United Nations ESCAP region, v. 10): United Nations ESCAP, Mineral Resources Development Series, no. 52, p. 63-69.

Yranova, N.V., and Talakanova, A.S., 1985, Scientific fundamental prospect of thick coal beds: U.S.S.R. All-Union Geological Institute, New Series, v. 325, p. 206 [in Russian].

Yrigoyen, M.R., Corvalán D., J., and Swint-Iki, T.R., 1991, Energy-resources map of the circum-Pacific region, southeast quadrant: U.S. Geological Survey Circum-Pacific Map Series CP-39, 59 p., scale 1:10,000,000.

Zha, Q., 1984, Jizhong Depression, China-its geologic framework, evolutionary history, and distribution of hydrocarbons: American Association of Petroleum Geologists Bulletin, v. 68, p. 983-992.

Zhang, J., 1985, Huabei-Bohai Basin, in United Nations Economic and Social Commission for Asia and the Pacific (ESCAP), Atlas of stratigraphy, Republic of China (Stratigraphic correlation between sedimentary basins of the United Nations ESCAP region, v. 10): United Nations ESCAP, Mineral Resources Development Series, no. 52, p. 22-27.

Zhang, Z.M., Liou, J.G., and Coleman, R.G., 1984, An outline of the plate tectonics of China: Geological Society of America Bulletin, v. 95, p. 295-312.

Zhang, Z., and Zheng, Q., 1985, Baise Basin, in United Nations Economic and Social Commission for Asia and the Pacific (ESCAP), Atlas of stratigraphy, Republic of China (Stratigraphic correlation between sedimentary basins of the United Nations ESCAP region, v. 10): United Nations ESCAP, Mineral Resources Development Series, no. 52 , p. $50-52$.

Zhao J., You, Y., and Zhou, X., 1985, Subei-South Yellow Sea Basin, in United Nations Economic and Social Commission for Asia and the Pacific (ESCAP), Atlas of stratigraphy, Republic of China (Stratigraphic correlation between sedimentary basins of the United Nations ESCAP region, v. 10): United Nations ESCAP, Mineral Resources Development Series, no. 52, p. 28-34.

Zhong, S., 1985, Pearl River Mouth Basin of South China Sea, in United Nations Economic and Social Commission for Asia and the Pacific (ESCAP), Atlas of stratigraphy, Republic of China (Stratigraphic correlation between sedimentary basins of the United Nations ESCAP region, $v$. 10): United Nations ESCAP, Mineral Resources Development Series, no. 52, p. 45-49. 
Zhou, Z., Qiu, S., and Huang, C., 1985, Songliao Basin, in United Nations Economic and Social Commission for Asia and the Pacific (ESCAP), Atlas of stratigraphy, Republic of China (Stratigraphic correlation between sedimentary basins of the United Nations ESCAP region, $v$. 10): United Nations ESCAP, Mineral Resources Development Series, no. 52, p. 13-21.

\section{SOUTHWEST QUADRANT}

Arnold, G.O., 1978, Summary of major Papua New Guinea sedimentary basins: Unpublished report for the ESCAP/ IGCP Sedimentary Basins Correlation Project, p. 1-11.

Australian Institute of Petroleum, 1993, Oil and Australia: Statistical Review 1993.

Cook, R., 1994, Petroleum system perspective of Taranaki Basin: Petroleum Exploration in New Zealand News, March 1994, p. 27.

Doutch, H.F., 1985, Geodynamic map of the circum-Pacific region, southwest quadrant: Tulsa, Oklahoma, American Association of Petroleum Geologists, scale 1:10,000,000, $12 \mathrm{p}$.

Doutch, H.F., 1986, Plate-tectonic map of the circum-Pacific region, southwest quadrant: Houston, Circum-Pacific Council for Energy and Mineral Resources, scale $1: 10,000,000,14 \mathrm{p}$.

Dow, D.B., Robinson, G.P., Hartono, U., and Ratman, N., 1988, Geology of Irian Jaya: Preliminary Geological Report, Indonesia-Australia Geological Mapping Project.

Drummond, K.J., 1986, Energy-resources map of the circumPacific region, northeast quadrant: Houston, Circum-Pacific Council for Energy and Mineral Resources, scale $1: 10,000,000,72$ p.

Edwards, A.B, and Glaessner, M.F., 1947, The mineral resources of the western Pacific islands: Proceedings of the Australasia Institute of Mining and Metallurgy, N.S., no. 147 , p. 75.

Gibson, D.L., 198x, Oil shale in Australia-its occurrence and resources: Australian Mining Industry Quarterly, v. 33(3), p. 105-113.

Palfreyman, W.D., 1988, Geologic map of the circum-Pacific region, southwest quadrant: Houston, Circum-Pacific Council for Energy and Mineral Resources, scale $1: 10,000,000,37 \mathrm{p}$.

Palfreyman, W.D., 1995, Mineral-resources map of the circumPacific region, southwest quadrant: Houston, CircumPacific Council for Energy and Mineral Resources, scale $1: 10,000,000,66 \mathrm{p}$

Paris, J.P., 1981, Geologie de la Nouvelle-Caledonie: France Bureau de Recherches Geologiques et Minieres, Memoire $113,278 \mathrm{p}$.

Rodgerson, R., 1986, Location, age, characteristics and exploitation potential of Papua New Guinea coal occurrences, in Martin, C.H., ed., Australasian coal mining practice: Australasian Institute of Mining and Metallurgy Monograph Series, no. 12, p. 52.
Rose, G., and McElroy, C.T., 1987, Coal potential of Antarctica: Canberra, Australia Bureau of Mineral Resources, Geology, and Geophysics, Report 2, 19 p.

Russell, P.L., 1990, Oil shales of the world: their origin, occurrence and exploitation: Oxford, Pergamon Press, 753 p.

Scheibner, E., 1991, Tectonic map of the circum-Pacific region, southwest quadrant: Houston, Circum-Pacific Council for Energy and Mineral Resources, scale 1:10,000,000, 59 p.

Valk, W., 1960, Notes on coal in Netherlands New Guinea, Nova Guinea: Geology, no. 1-3, p. 1-4.

Valk W., 1960, The mining potential of Netherlands New Guinea, Nova Guinea: Geology, no. 1-3, p. 5.

Wells, A.T., 1981, A summary of coal occurrences in Australian sedimentary basins: Bureau of Mineral Resources, Australia, Record 1981/48, p. 1.

Yrigoyen, M., Corvalán D.J., and Swint-Iki, T.R., 1991, Energy-resources map of the circum-Pacific region, southeast quadrant: Houston, Circum-Pacific Council for Energy and Mineral Resources, scale 1:10,000,000, 59 p.

\section{ADDITIONAL SOURCES OF DATA}

\section{PACIFIC BASIN REFERENCES}

BP Amoco, 1999, Statistical Review of World Energy, 1998.

Carmalt, S.W., and St. John, Bill, 1986, Giant oil and gas fields, in Halbouty, M.T., ed., Future petroleum provinces of the world, Proceedings of the Wallace E. Pratt Memorial Conference, Phoenix, Arizona, December 1984; American Association of Petroleum Geologists, Memoir 40, p. 11-53.

Corvalan Diaz, J., 1991, Energy-Resources Map of the CircumPacific Region, Southeast Quadrant: U.S. Geological Survey, Circum-Pacific Map Series Map CP-39, scale $1: 10,000,000,2$ sheets.

Drummond K. J., 1986, Energy-Resources Map of the CircumPacific Region, Northeast Quadrant: American Association of Petroleum Geologists, scale 1:10,000,000.

Drummond, K.J., 1987, Energy Resources Map of the Northeast Quadrant: Energy Resources Map Series, CircumPacific Map Project, in Horn, M.K., ed., Transactions of the Fourth Circum-Pacific Energy and Minerals Resources Conference, Singapore, p. 445-454.

Drummond, K.J., 1989, Petroleum Habitat on the Pacific Rim, [abs], Abstracts of the 28th International Geological Congress, Washington, D.C., p. 420.

Drummond, K.J., 1992, Petroleum Habitat of the Pacific Region and the Energy Resources Map Series of the CircumPacific Map Project, [abs], Abstracts of the 29th International Geological Congress, Kyoto, Japan.

International Petroleum Encyclopedia, 1999, PennWell Publishing co., Tulsa, Ok.

Johnson, R.W., in prep, Energy-Resources Map of the CircumPacific Region, Southwest Quadrant: U.S. Geological Survey, Circum-Pacific Map Series Map CP-xx, scale $1: 10,000,000$ 
Klett, T.R., Ahlbrandt, T.S., Schmoker, J.W., and Dolton, G.L., 1997, Ranking of the world's oil and gas provinces by known petroleum volumes: U.S. Geological Survey Open File Report 97-463, 1 CD-ROM.

Magoon, L.B., and Dow, W.G., eds., 1994a, The petroleum system-From source to trap: American Association of Petroleum Geologists Memoir 60, 655 p.

Masters, C.D., 1993, World petroleum resources B where, why, and how much? : Geological Society of Malaysia, Bulletin 33, p. 5-19.

Masters, C.D., Attanasi, E.D., and Root, D.H., 1994, World petroleum assessment and analysis: in Proceedings of the 14th World Petroleum Congress: John Wiley and Sons, London, p.529-541.

Masters, C.D., Attanasi, E.D., Dietzman, W.D., Meyer, R.F., Mitchell, R.W., and Root, D.H., 1987, World resources of crude oil, natural gas, natural bitumen, and shale oil: in Proceedings of the 12th World Petroleum Congress, John Wiley \& Sons, Chichester, England, v. 5, p. 3-27.

Masters, C.D., Root, D. H., and Turner, R. M., 1998, World Conventional Crude Oil and Natural Gas: Identified Reserves, Undiscovered Resources and Futures: U.S. Geological Survey Open File Report 98-468 (August) 105, p. 2 plates.

Masters, C.D., Root, D.H., and Attanasi, E.D., 1990, World Oil and Gas Resources-Future Production Realities, Annu. Rev. Energy, vol. 15, p. 23-51.

Masters, C.D., Root, D.H., and Attanasi, E.D., 1991, World resources of crude oil and natural gas: in Proceedings of the 13th World Petroleum Congress, John Wiley \& Sons, Chichester, England, p. 51-64.

Masters, C.D., Root, D.H., and Dietzman, W.D., 1984, Distribution and quantitative assessment of world crude oil reserves and resources: in Proceedings of the 11 th World Petroleum Congress, John Wiley \& Sons, Chichester, England, v. 2, p. 229-237.

Masters, C.D., Root, D.H., and Turner, R.M., 1997, World of resource statistics geared for electronic access: Oil \& Gas Journal, v. 95, no. 41, p. 98-104.

Moritani, T., 1992, Energy-Resources Map of the Circum-Pacific Region, Northwest Quadrant: U.S. Geological Survey, Circum-Pacific Map Series Map CP-40, scale $1: 10,000,000$

Oil and Gas Journal, 1961-1998, Worldwide report issues; Oil and Gas Journal, v. 59-96.

Ruthven, C.L., editor, 1994, Prodeedings of the Global Gas Resources Workshop, November 1994, Vail Colorado, 270 p.

Ulmishek, G.F. and Klemme, H.D., 1990, Depositional Controls, Distribution, and Effectiveness of World's Petroleum Source Rocks: U.S. Geological Survey Bulletin $1931,59 \mathrm{p}$.

World Oil, August 1980-98, International Outlook.

\section{NORTHEAST QUADRANT}

Biddle, K.T., ed., Active Margin Basins, American Association of Petroleum Geologists Memoir 52, 324 p.
Bird, K.J., 1988, Alaskan North Slope stratigraphic nomenclature and data summary for government-drilled wells, in Gyrc, G., ed., Geology and exploration of the National petroleum Reserve in Alaska, 1974 to 1982, U.S. Geological Survey Professional Paper 1399, p. 317-353.

Bird, K.J., 1989, North American fossil fuels, in Bally, A.W., and Palmer, A.R. eds., The Geology of North AmericaAn overview: Boulder, Colorado, Geological Society of America, The Geology of North America, v. A.

Bowers, B., and Drummond, K.J., 1997, Conventional Crude Oil Resources of the Western Canada Sedimentary Basin, Journal of Canadian Petroleum Technology, v. 36, no. 2 , p. 56-63.

Canadian Association of Petroleum Producers, 1999, 1998 Statistical Handbook.

Canadian Gas Potential Committee, 1997, Natural Gas Potential in Canada.

Dixon, J., Morrell, G.R., Dietrich, J.R., Procter, R.M., and Taylor, G.C., 1988, Petroleum resources of the Mackenzie Delta-Beaufort Sea; Geological Survey of Canada OpenFile 1926, 74 p.

Drummond, K.J., 1987, Energy Resources Map of the Northeast Quadrant: Energy Resources Map Series, CircumPacific Map Project, in Horn, M.K., ed., Transactions of the Fourth Circum-Pacific Energy and Minerals Resources Conference, Singapore, p. 445-454.

Dunkel, C.A., and Piper, K.A., editors, 1997, 1995 National Assessment of United States Oil and Gas Resources, Assessment of the Pacific Outer Continental Shelf Region, Minerals Management Service, OCS Report MMS 970019.

Gautier, D.L., Dolton, G.L., Takahashi, K.I., and Varnes, K.L., eds., 1995, 1995 National Assessment of United States Oil and Gas Resources-Results, Methodology, and Supporting Data: U.S. Geological Survey Digital Data Series DDS-30.

Hannigan, P.K., Dietrich, J.R., Lee, P.J., and Osadetz, K.G., 1998, Petroleum Resource Potential of Sedimentary Basins on the Pacific Margin of Canada, Geological Survey of Canada, Open File 3629, 85 p.

Kirschner, C.E., 1988, Map showing sedimentary basins of onshore and continental shelf areas, Alaska, U.S. Geological Survey Miscellaneous Investigations Series Map I-1873, scale 1:2,500,000.

Lore, G.L., Brooke, J.P., Cooke, D.W., Klazynski, R.J., Olson, D.L., and Ross, K.M., 1996, Summary of the 1995 assessment of conventionally recoverable hydrocarbon resources of the Gulf of Mexico and Atlantic Outer Continental Shelf, Minerals Management Service, OCS Report MMS 96-0047, $67 \mathrm{p}$.

Minerals Management Service, 1996, An assessment of the undiscovered hydrocarbon potential of the Nation's Outer Continental Shelf, Minerals Management Service OCS Report MMS 96-0034, 40 p.

Potential Gas Committee, 1999, Potential supply of natural gas in the United States (December 31, 1998): Golden, Colo., Potential Gas Agency, Colorado School of Mines, 195 p., 2 pls. 
Santiago, J., and Baro, A, 1992, Mexico's Giant Fields, in Halbouty, M.T., Giant Oil and Gas Fields of the Decade 1978-1998, American Association of Petroleum Geologists Memoir 52, p. 73-99.

Sherwood, K.W., Craig, J.D., and Larry W. Cooke, L.W., 1996, Endowments of Undiscovered Conventionally Recoverable and Economically Recoverable Oil and Gas in the Alaska Federal Offshore, as of January 1995, Minerals Management Service, OCS Report MMS 96-0033.

U.S. Geological Survey, 1995, 1995 National Assessment of United States oil and gas resources: U.S. Geological Survey Circular $1118,20 \mathrm{p}$.

Young, S.B., and Drummond, K.J., 1994, An Analysis of the Canadian Natural Gas Resource Base, in Ruthven C.L., ed, Proceedings of the Global Gas Resources Workshop, September 19-21, 1994, Vail, Colorado, p. 65-73.

\section{SOUTHEAST QUADRANT}

Kingston, J., 1994, Undiscovered Petroleum of Southern South America, U.S. Geological Survey Open-File 97 $559,443 \mathrm{p}$.

Lindquist, S.J., 1998a, The Santa Cruz-Tarija province of central South America: Los Monos-Machareti(!) petroleum system: U.S. Geological Open-file 99-50C.

McCollough, C.N., and Carver, J.A., 1992, The Giant Cano Limon Field, Llanos Basin, Colombia, in Halbouty, M.T., Giant Oil and Gas Fields of the Decade 1978-1998, American Association of Petroleum Geologists Memoir 52, 324 p. 175-195.

Prieto, R., and Valdes, G., 1992 El Furrial Oil Field, A Giant in an Old Basin, in Halbouty, M.T., Giant Oil and Gas Fields of the Decade 1978-1998, American Association of Petroleum Geologists Memoir 52, 324 p. 155-161.

Ramirez, E., and Marcano, F., 1992, Ceuta-Tomoporo Field, Venezuela, in Halbouty, M.T., Giant Oil and Gas Fields of the Decade 1978-1998, American Association of Petroleum Geologists Memoir 52, 324 p. 163-173.

Schamel, S., 1991, Middle and Upper Magdalena Basins, Colombia, in Biddle, K.T., ed., Active Margin Basins, American Association of Petroleum Geologists Memoir 52, p. 283-301.

Schenk, C.J., 1997, Map showing geology, oil and gas fields, and geologic provinces of South America: U.S. Geological Survey Open-File 97-470D, 1 CD-ROM.
Tankard, A.J., Suarez S., R., and Welsink, H.J., editors, 1995, Petroleum Basins of South America, American Association of Petroleum Geologists, Memoir 62, 792 p.

\section{SOUTHWEST QUADRANT}

Bishop, M.B., 1999a, A total petroleum system of the Browse Basin, Australia: The Dingo-Mungaroo/Barrow and the Locker-Mungaroo/Barrow: U.S. Geological Survey Open-File Report 99-50E.

Bishop, M.B., 1999b, A total petroleum system of the Browse Basin, Australia: Late Jurassic/Early Cretaceous-Mesozoic: U.S. Geological Survey Open-File Report 99-50I.

Steinshouer, D.W., Qiang, J., McCabe, P.J., and Ryder, R.T., 1997, Maps showing geology, oil and gas fields and geologic provinces of the Asia Pacific Region: U. S. Geological Survey Open-file Report 97-470F, 1 CD-ROM.

Wandrey, C.J., and Law, B.E., 1997, Maps showing geology, oil and gas fields and geological provinces of South Asia: U.S. Geological Survey Open-file Report 97-470C, 1 CD-ROM.

\section{NORTHWEST QUADRANT}

Clarke, J.W., 1988, Sedimentary basins of northeastern U.S.S.R.; U.S. Geological Survey Open-File Report 88264, 59 p.

Lindquist, S.J., 1998c, The Timan-Pechora basin province of northwest Arctic Russia: Domanik - Paleozoic Total Petroleum System: U. S. Geological Survey Open-file 99. $50 \mathrm{G}$.

Peterson, J.A., and Clarke, J.W., 1991, Geology and Hydrocarbon Habitat of the West Siberian Basin, American Association of Petroleum Geologists Studies in Geology \#32, 96 p.

Persits, F.M., Ulmishek, G.F., and Steinshouer, D.W., 1997b, Map showing geology, oil and gas fields, and geologic provinces of the Former Soviet Union: U.S. Geological Survey Open-File 97-470E, CD-ROM.

Ulmishek, G.F., and Masters, C.D., 1993, Estimated petroleum resources in the former Soviet Union, USGS Open-File Report 93-316, 18 p.

Ulmishek, G.F., and Masters, C.D., 1993, Oil, gas resources estimated in the former Soviet Union, Oil and Gas Journal, Dec. 13, 1993, p. 59-62. 


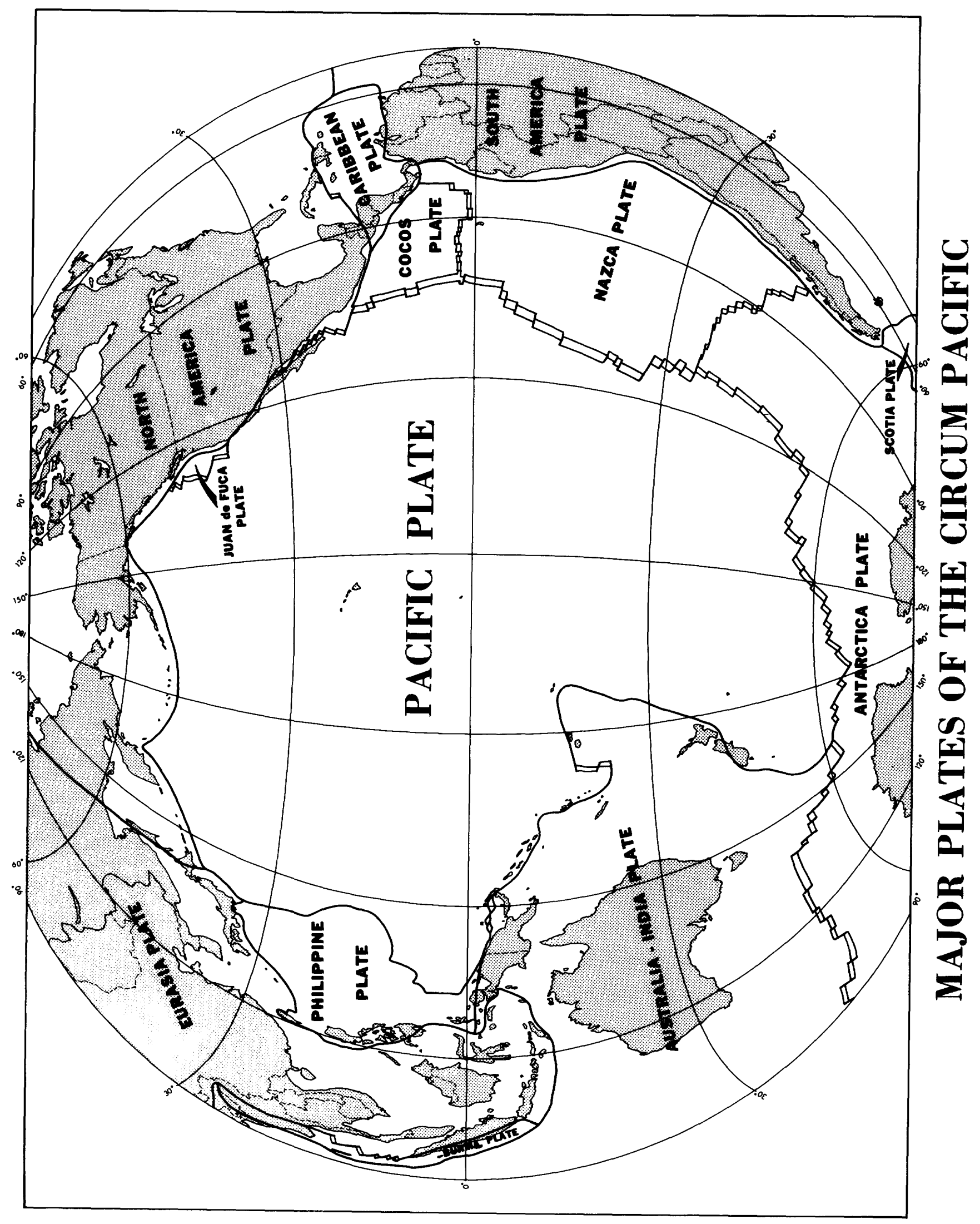

Figure 1. Plate-tectonic setting, Circum-Pacific Region. 


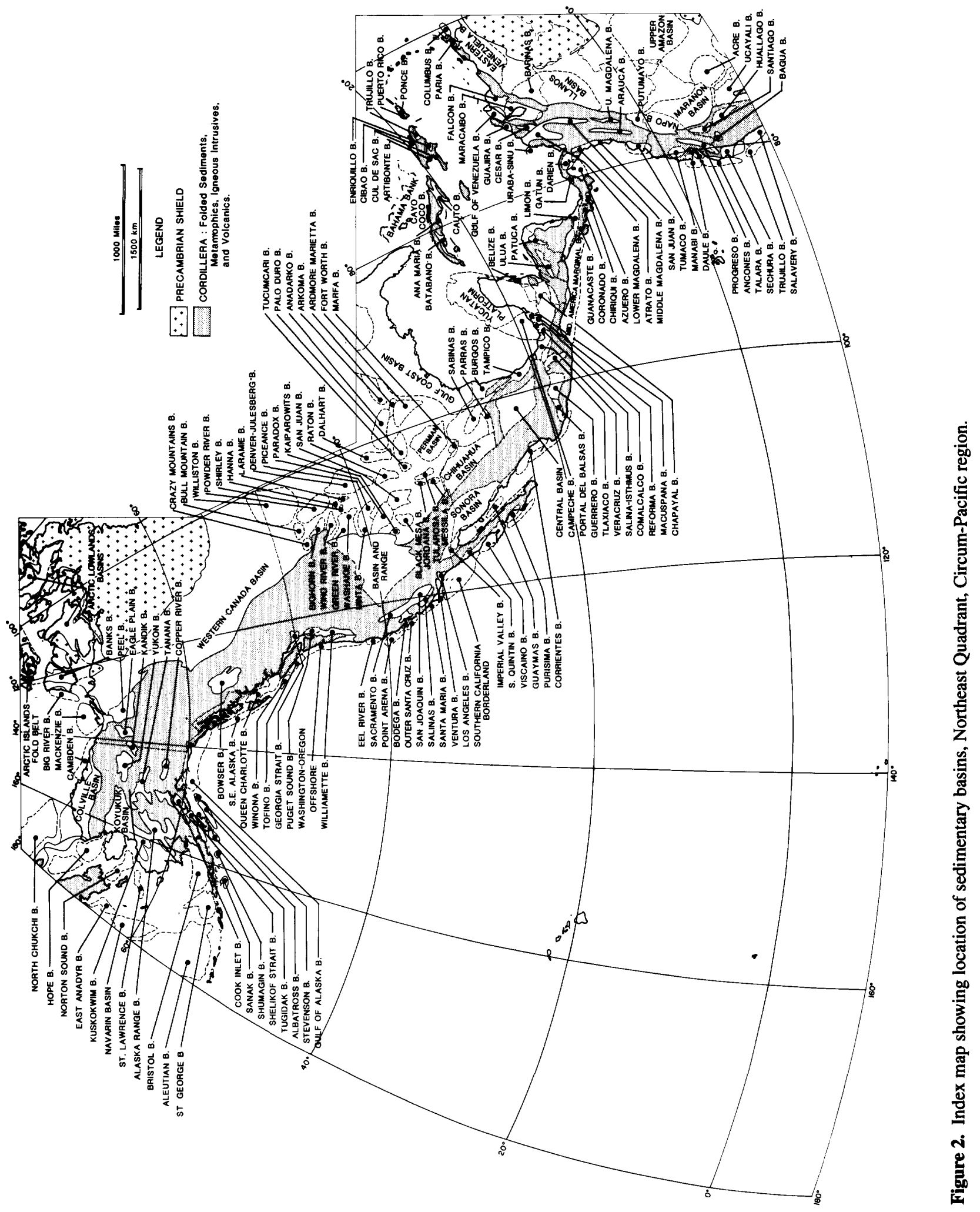




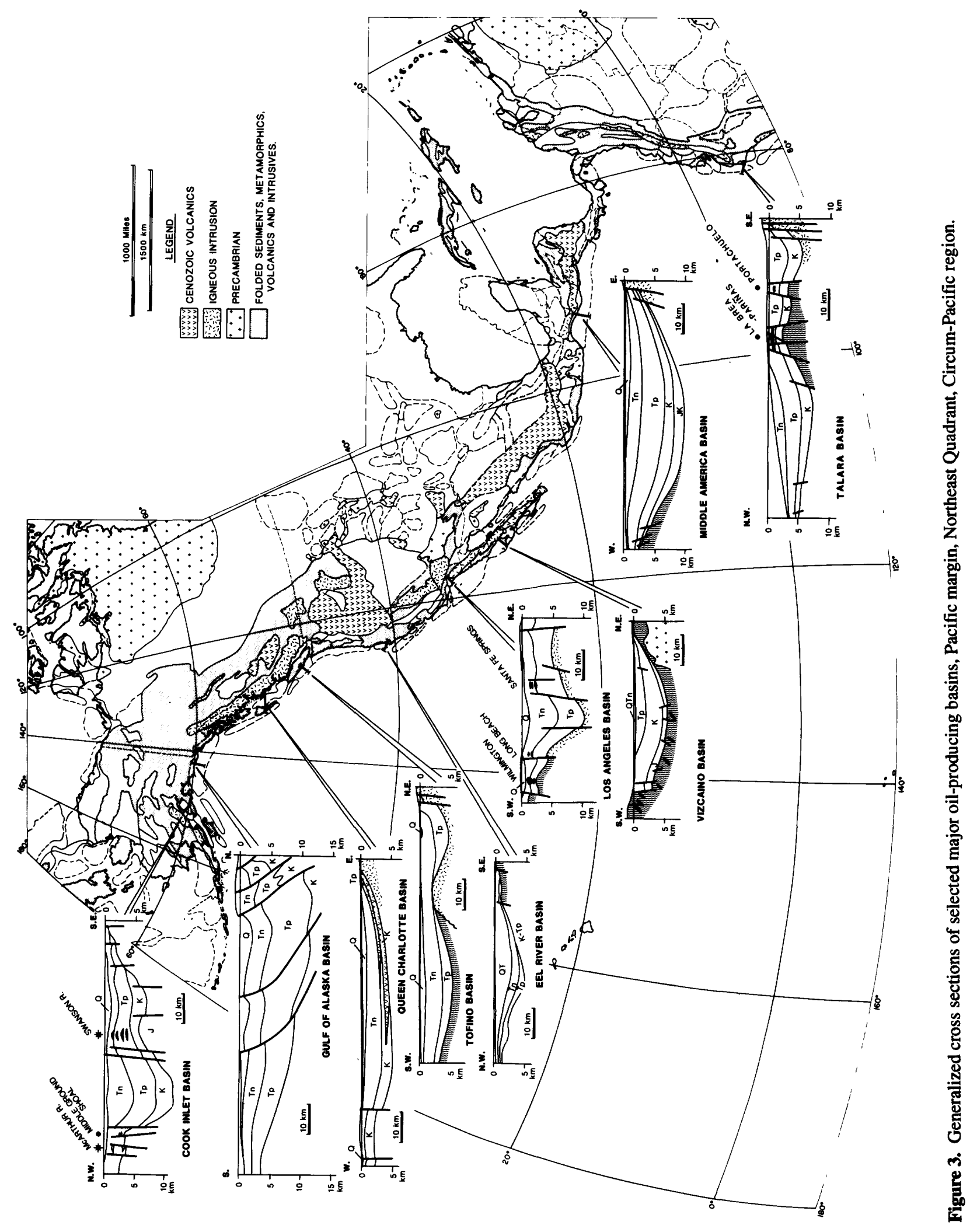




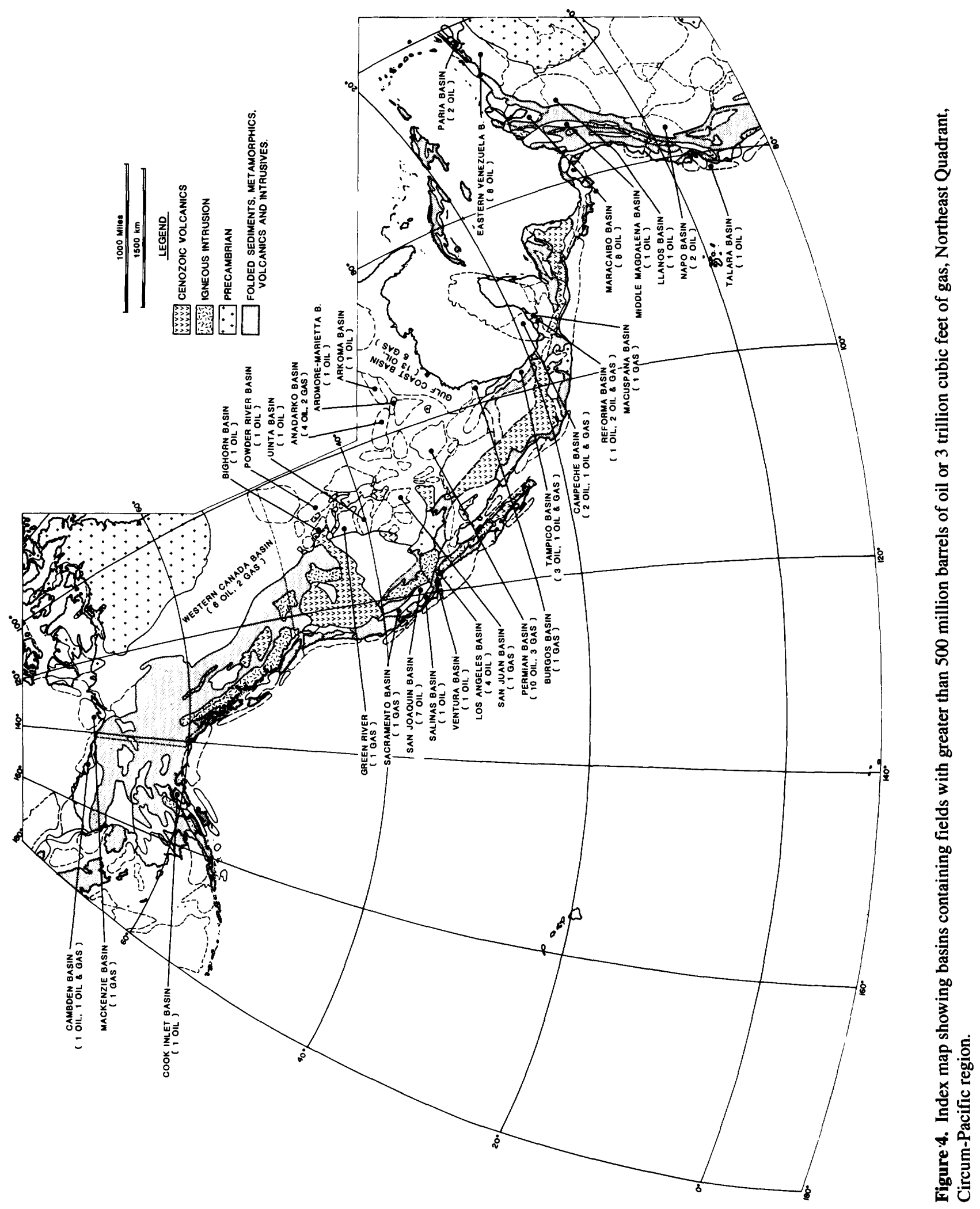




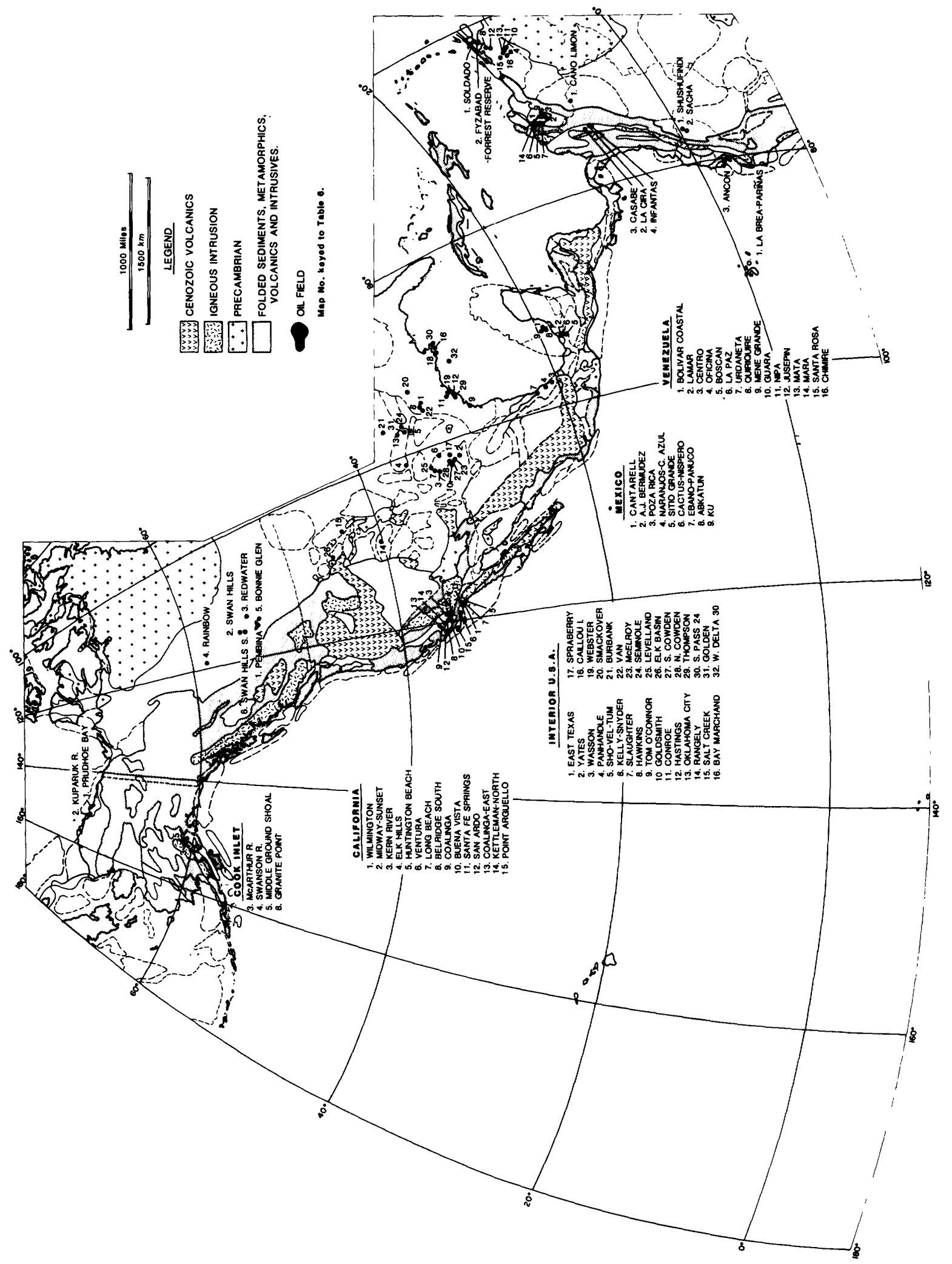

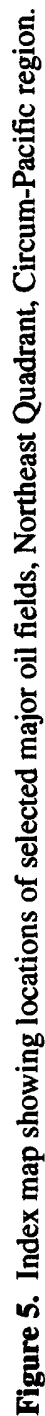




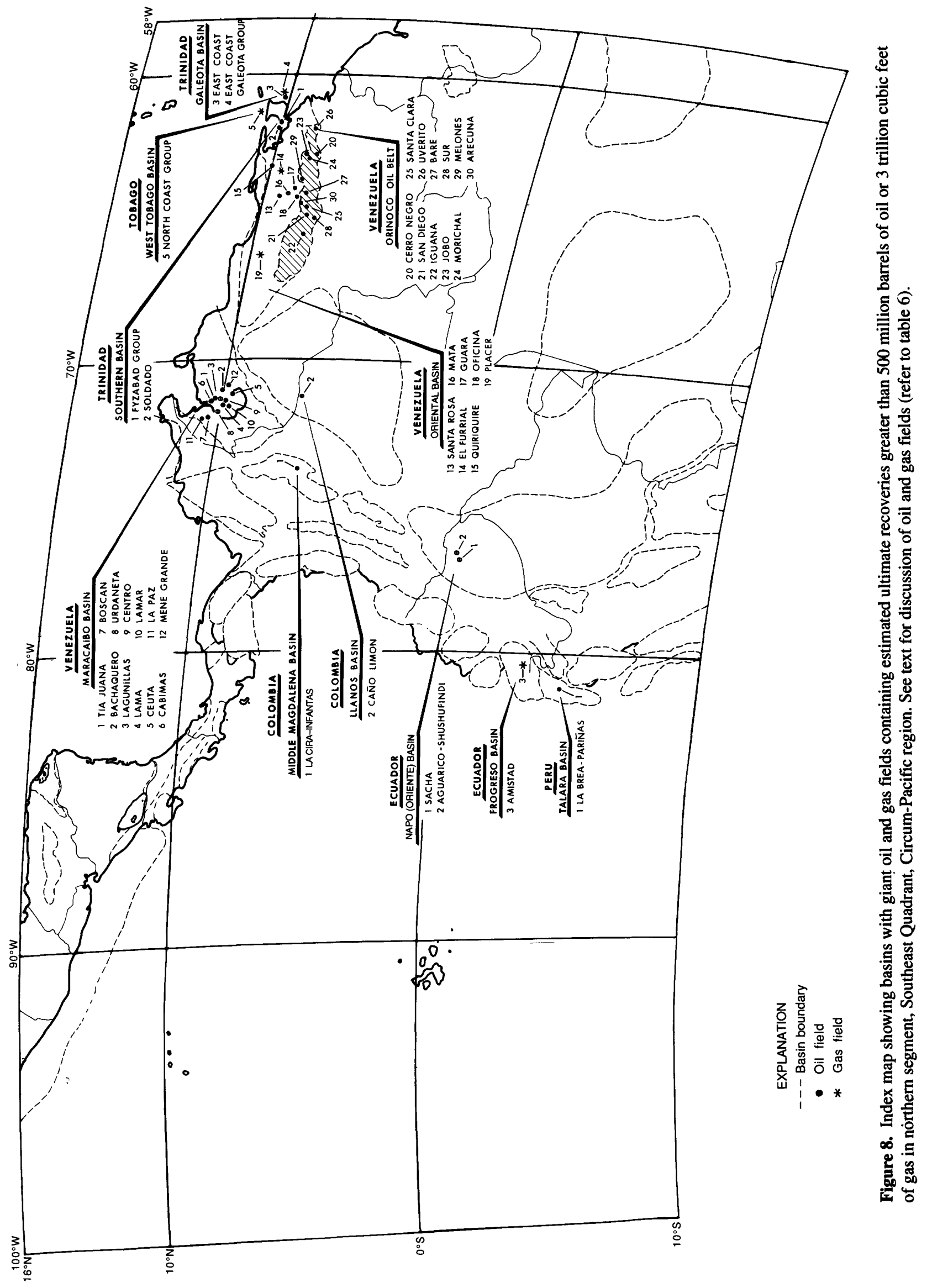




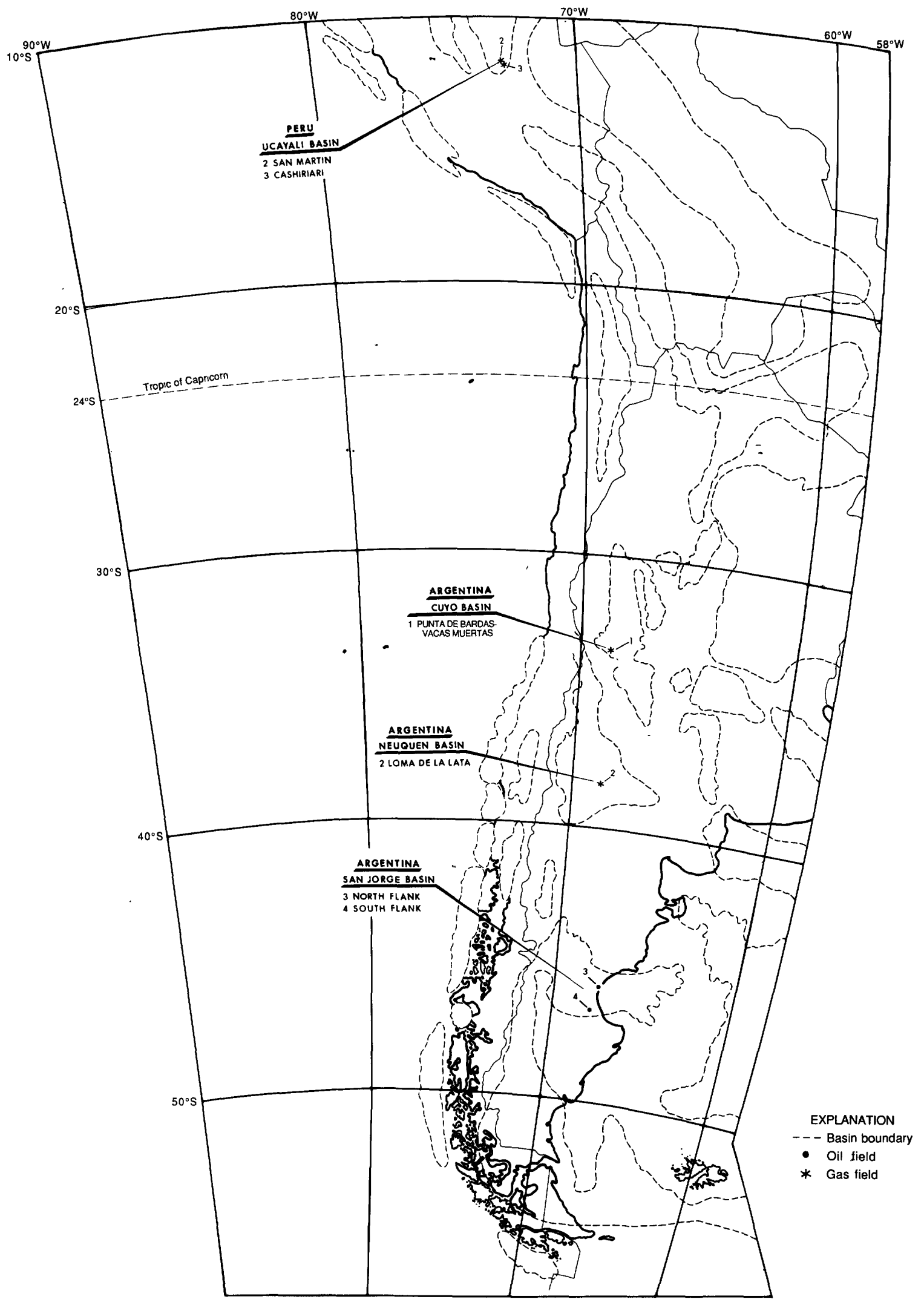

Figure 9. Index map showing basins with giant oil and gas fields containing estimated ultimate recoveries greater than 500 million barrels of oil or 3 trillion cubic feet of gas in southern segment, Southeast Quadrant, Circum-Pacific region (refer to table 6). 


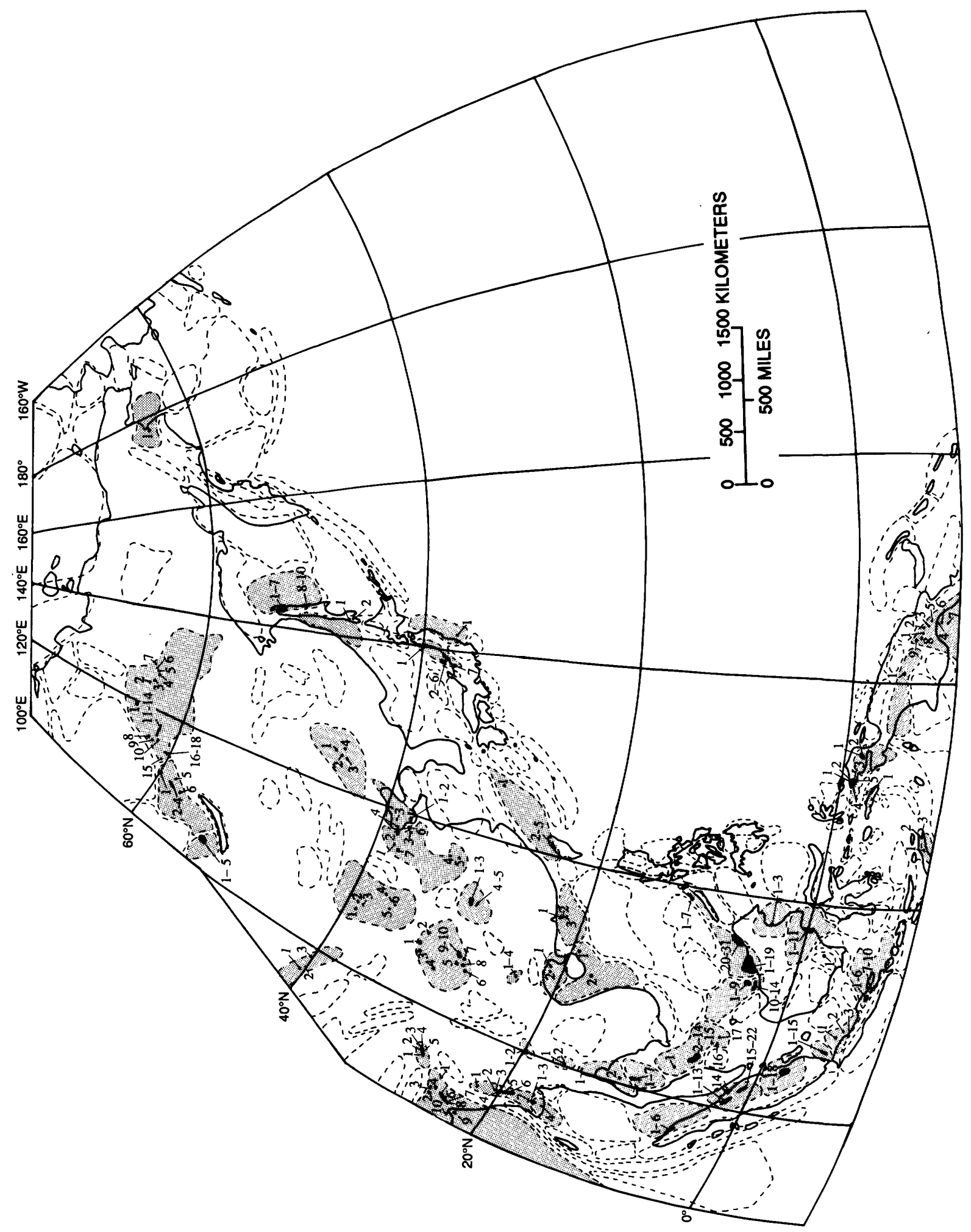

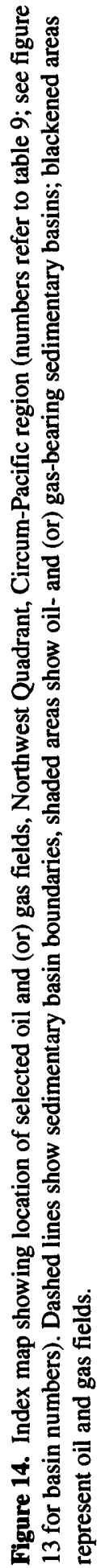




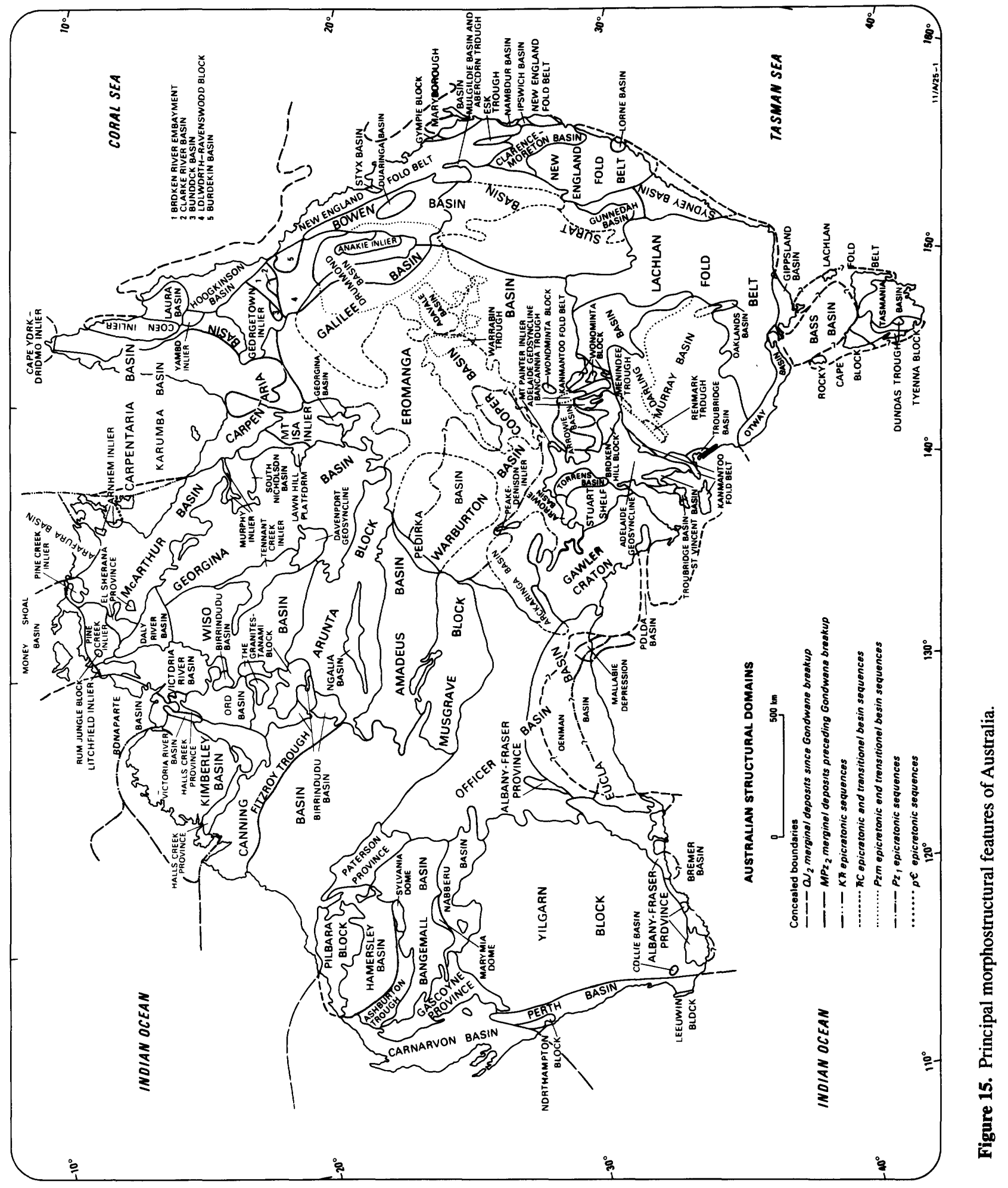




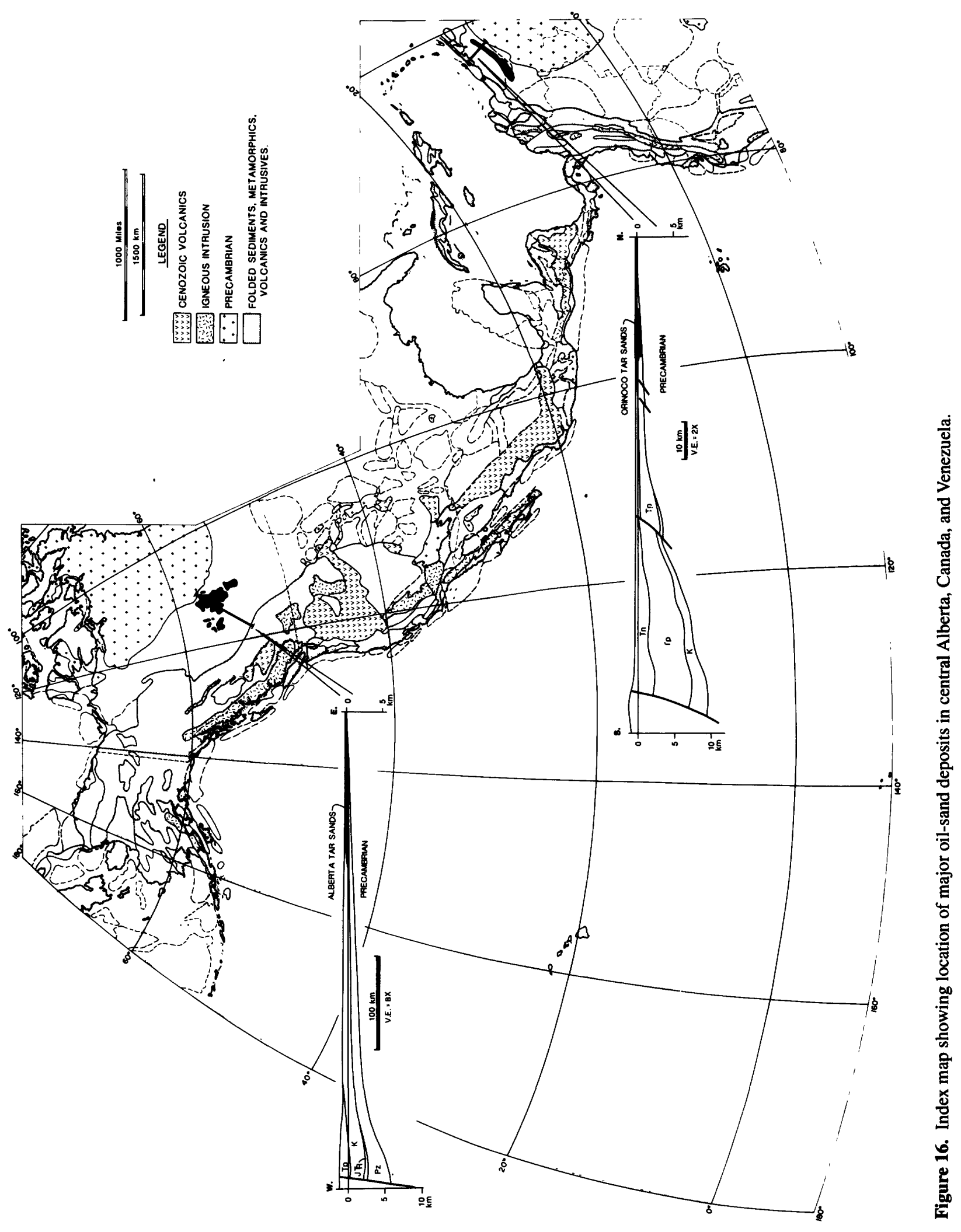




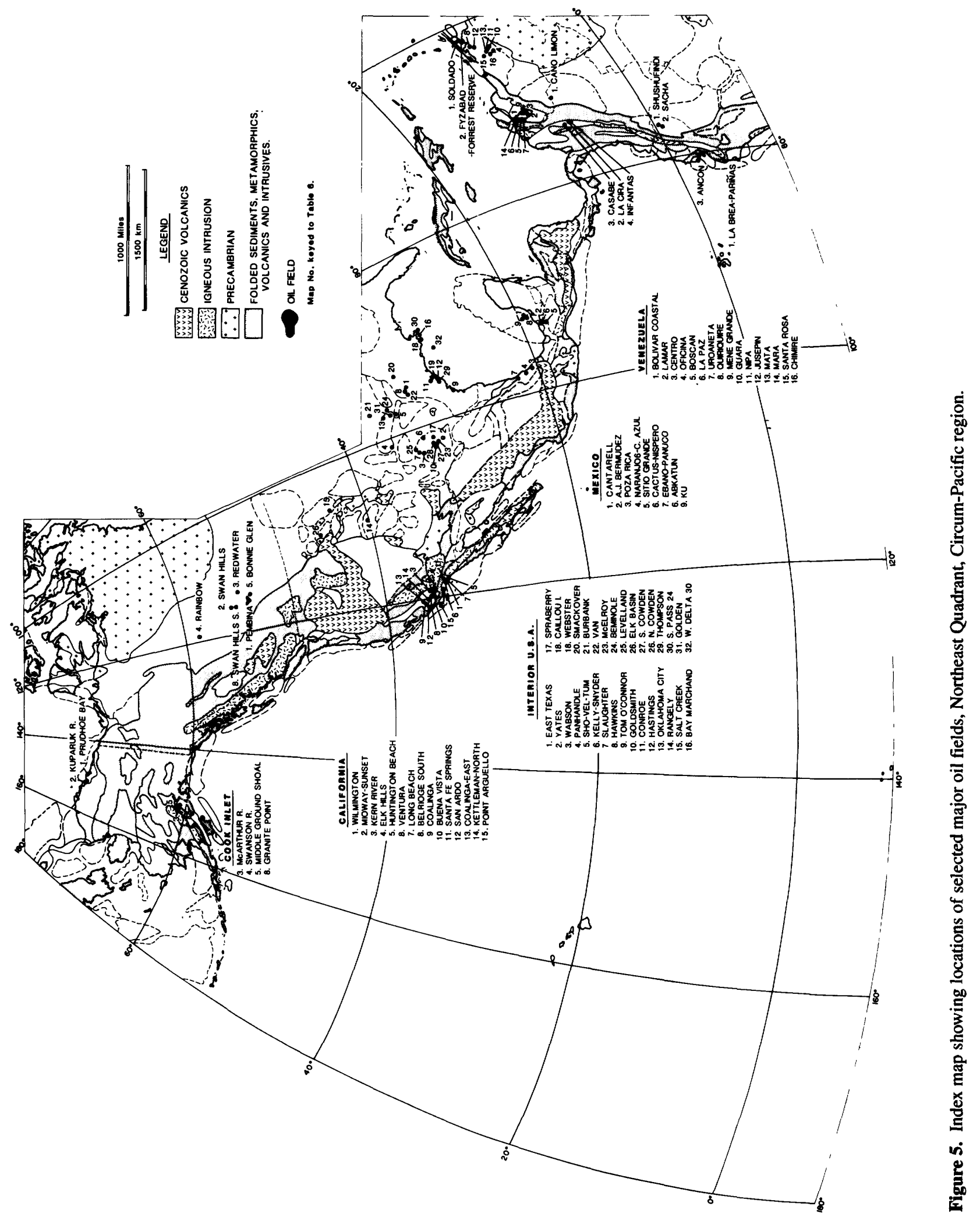




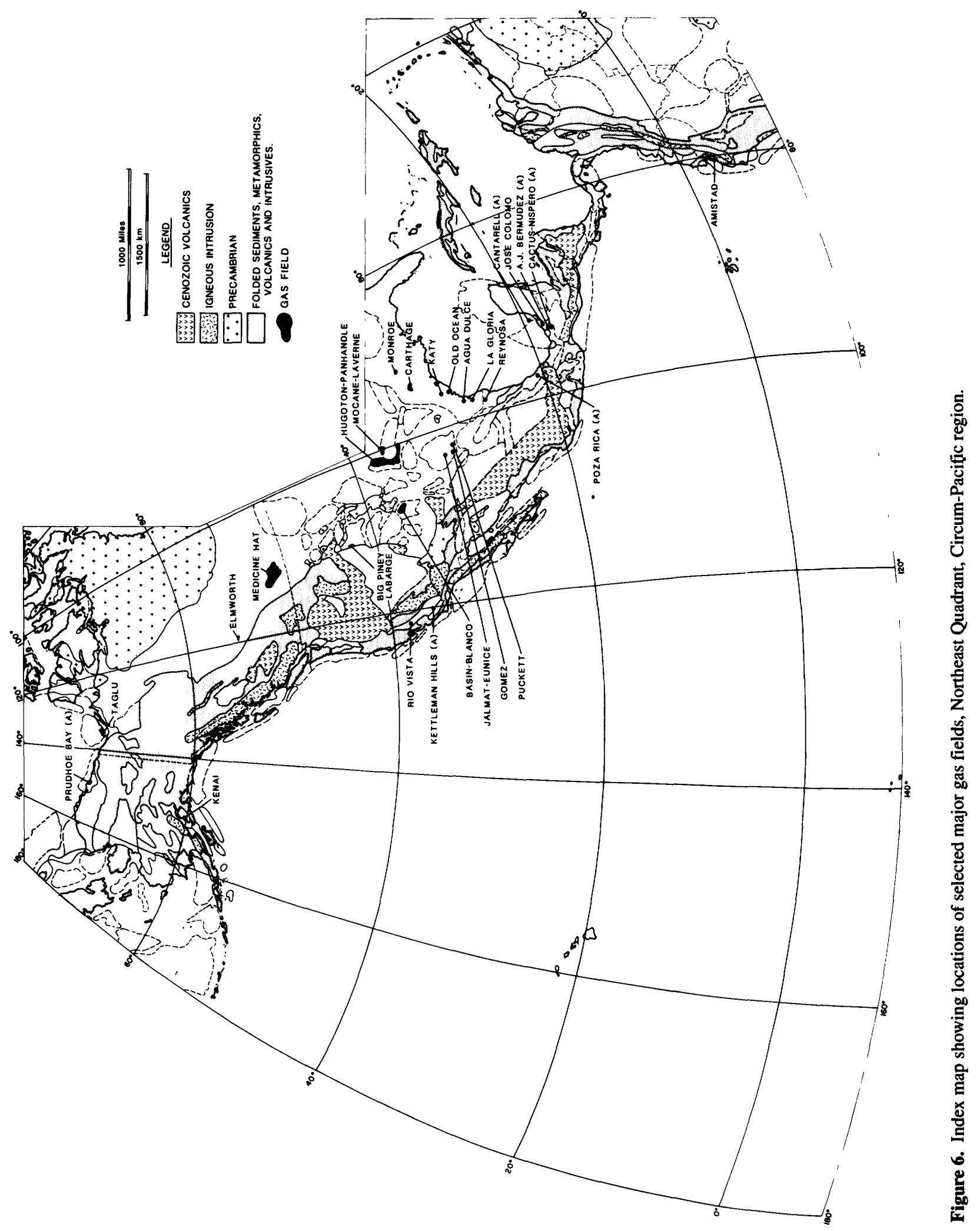



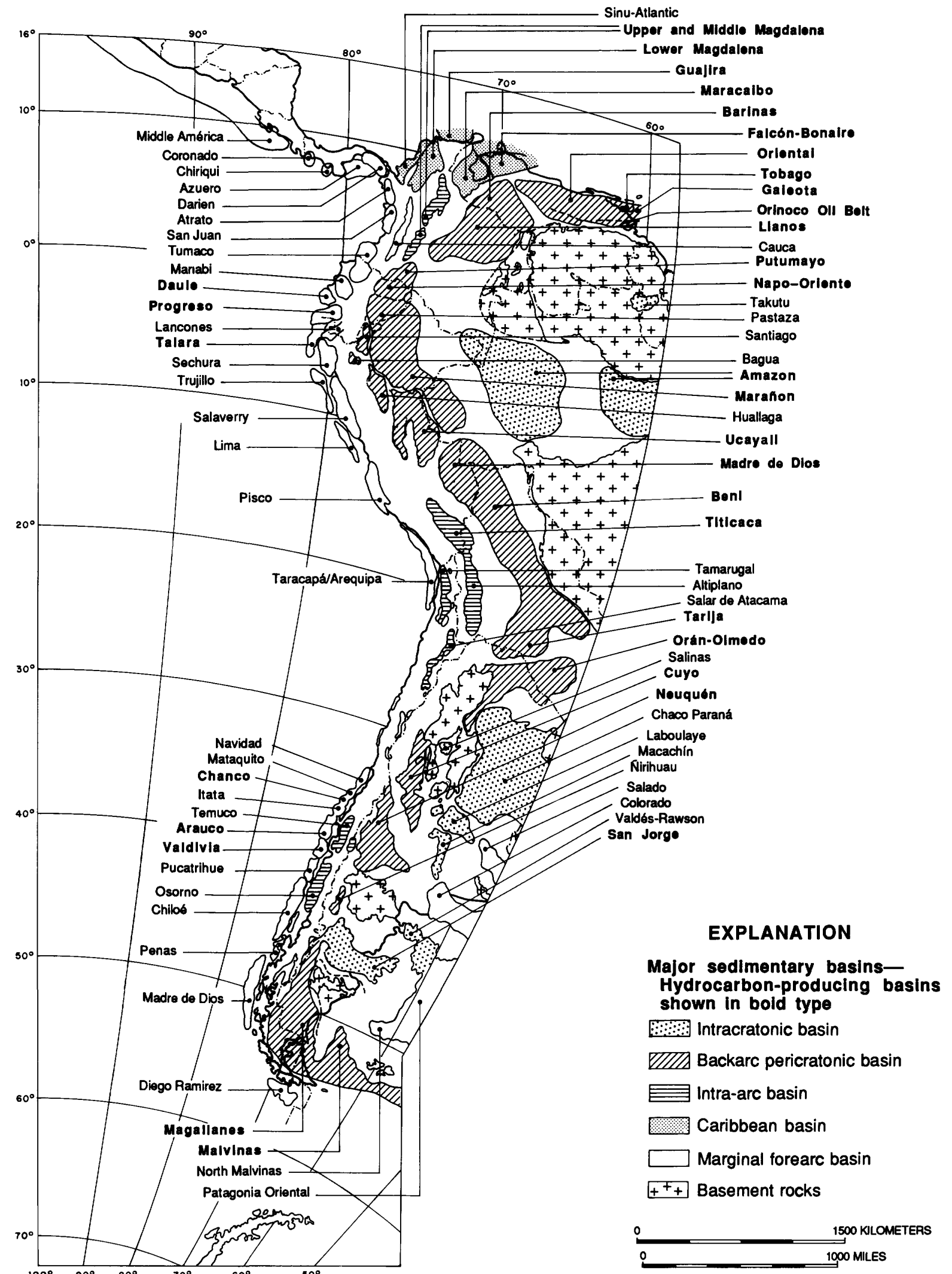

Figure 7. Index map showing location of major sedimentary basins, Southeast Quadrant, Circum-Pacific region. Basin boundary dashed where approximately located. 


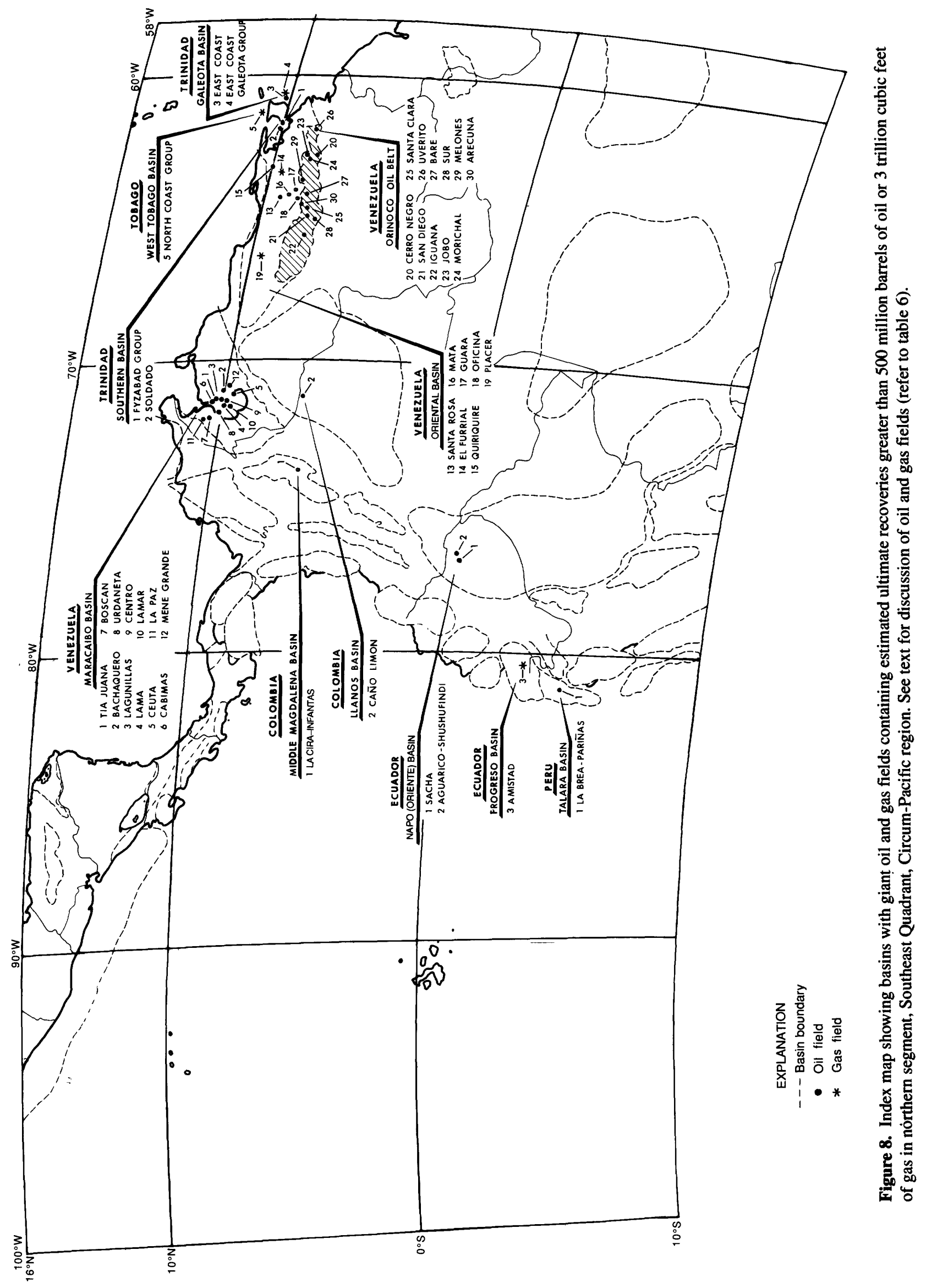




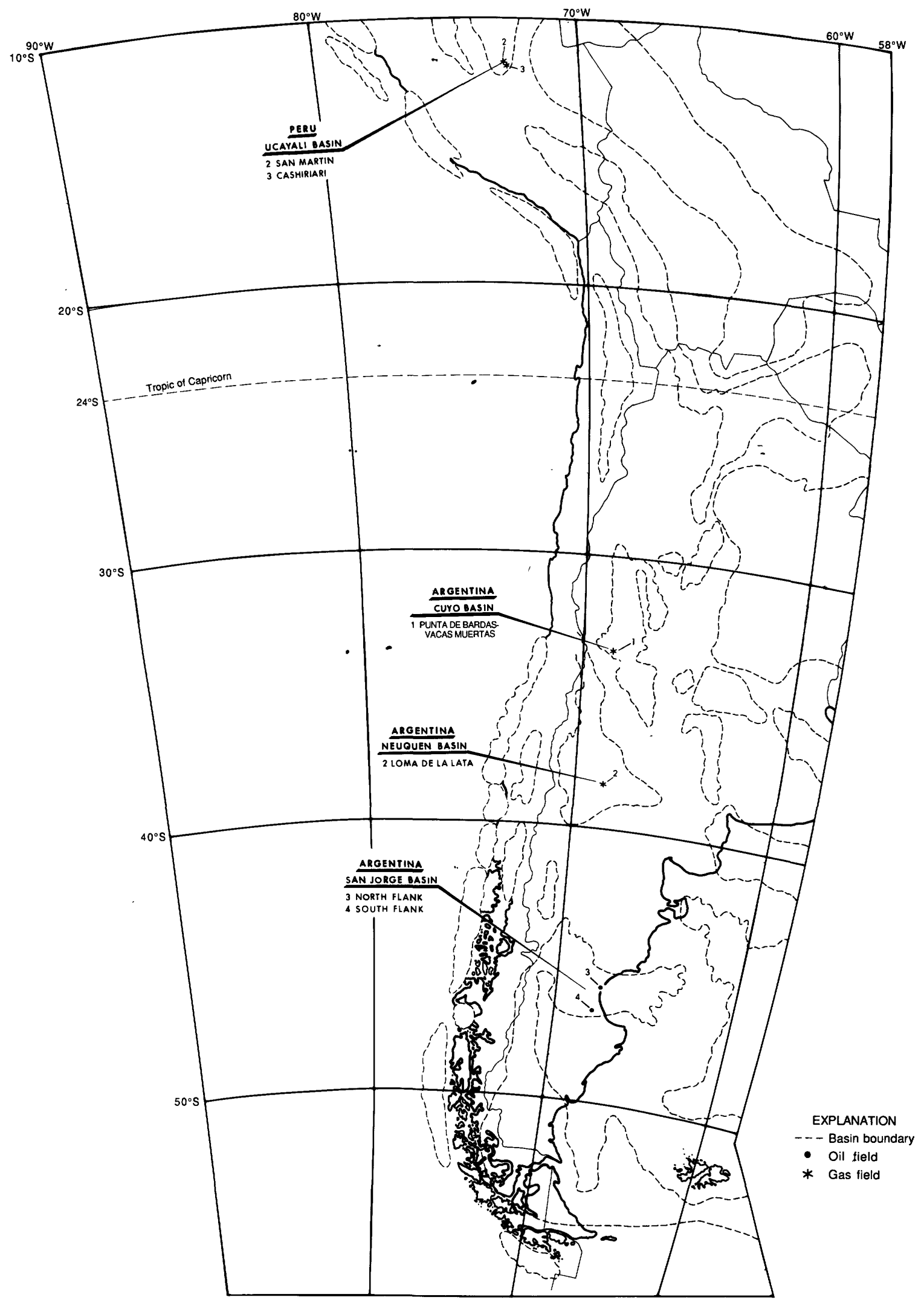

Figure 9. Index map showing basins with giant oil and gas fields containing estimated ultimate recoveries greater than 500 million barrels of oil or 3 trillion cubic feet of gas in southern segment, Southeast Quadrant, Circum-Pacific region (refer to table 6). 


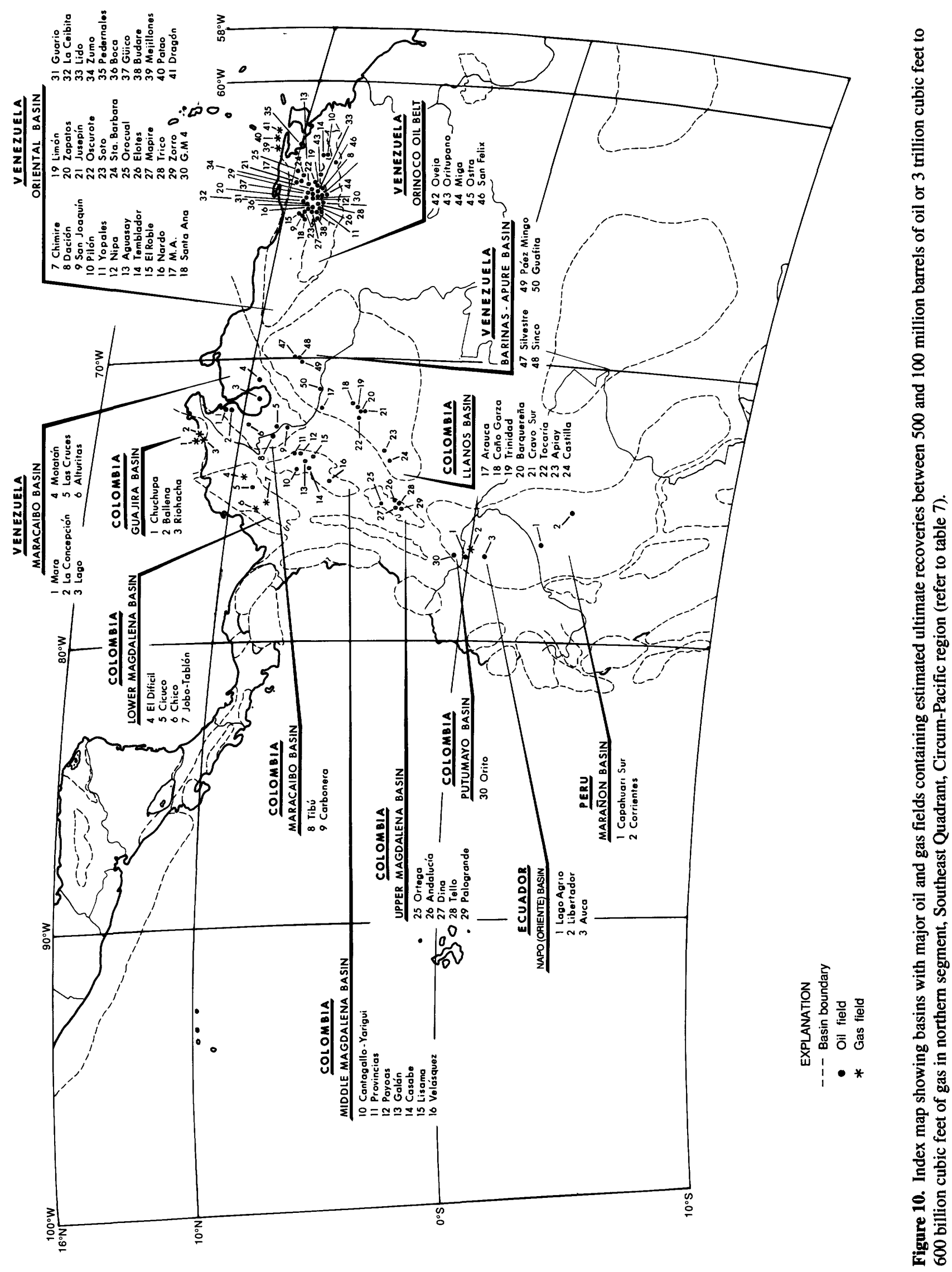




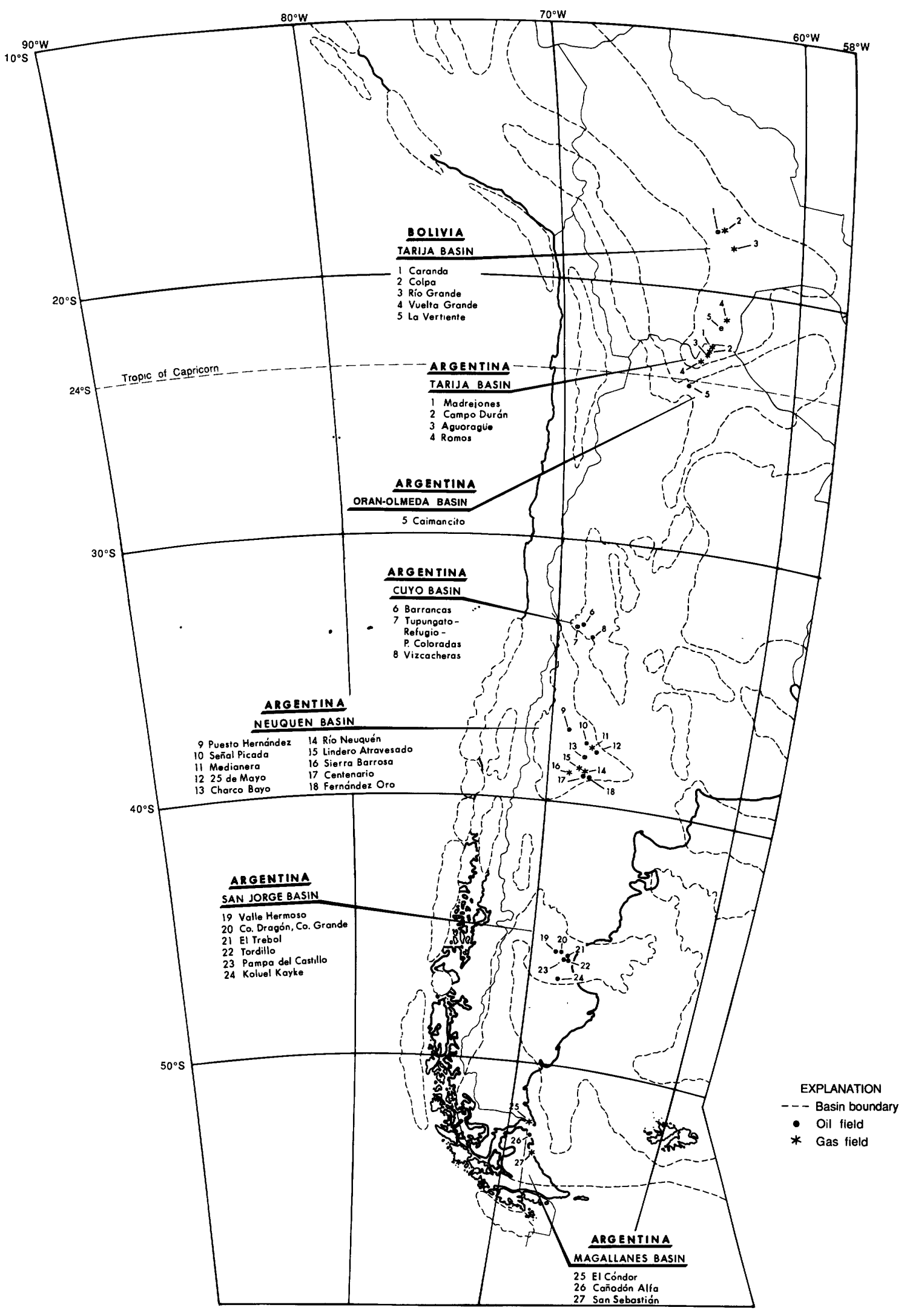

Figure 11. Index map showing basins with major oil and gas fields containing estimated ultimate recoveries between 500 and 100 million barrels of oil or 3 trillion cubic feet to 600 billion cubic feet of gas in southern segment, Southeast Quadrant, Circum-Pacific region (refer to table 7). 


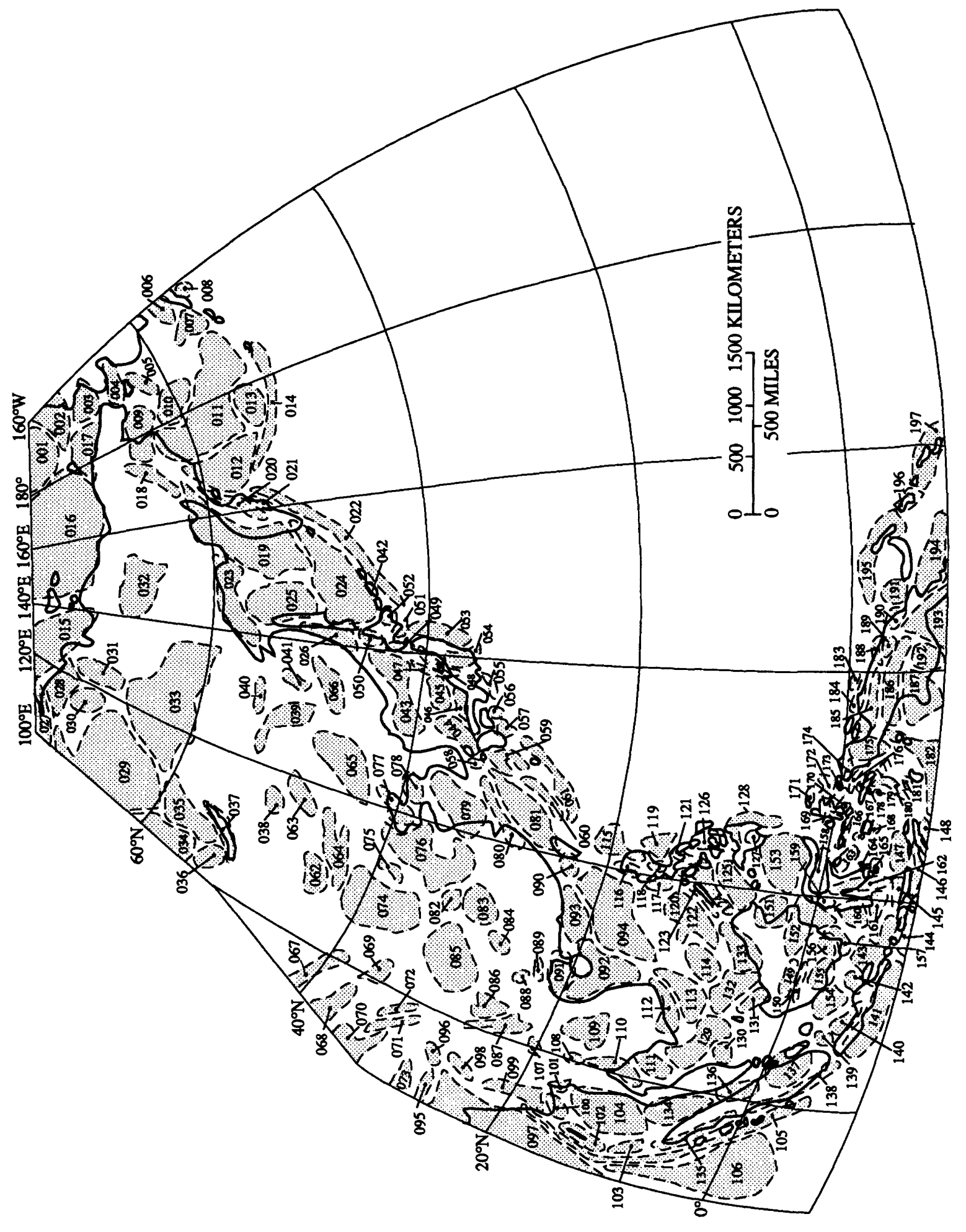

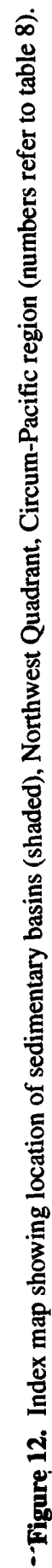




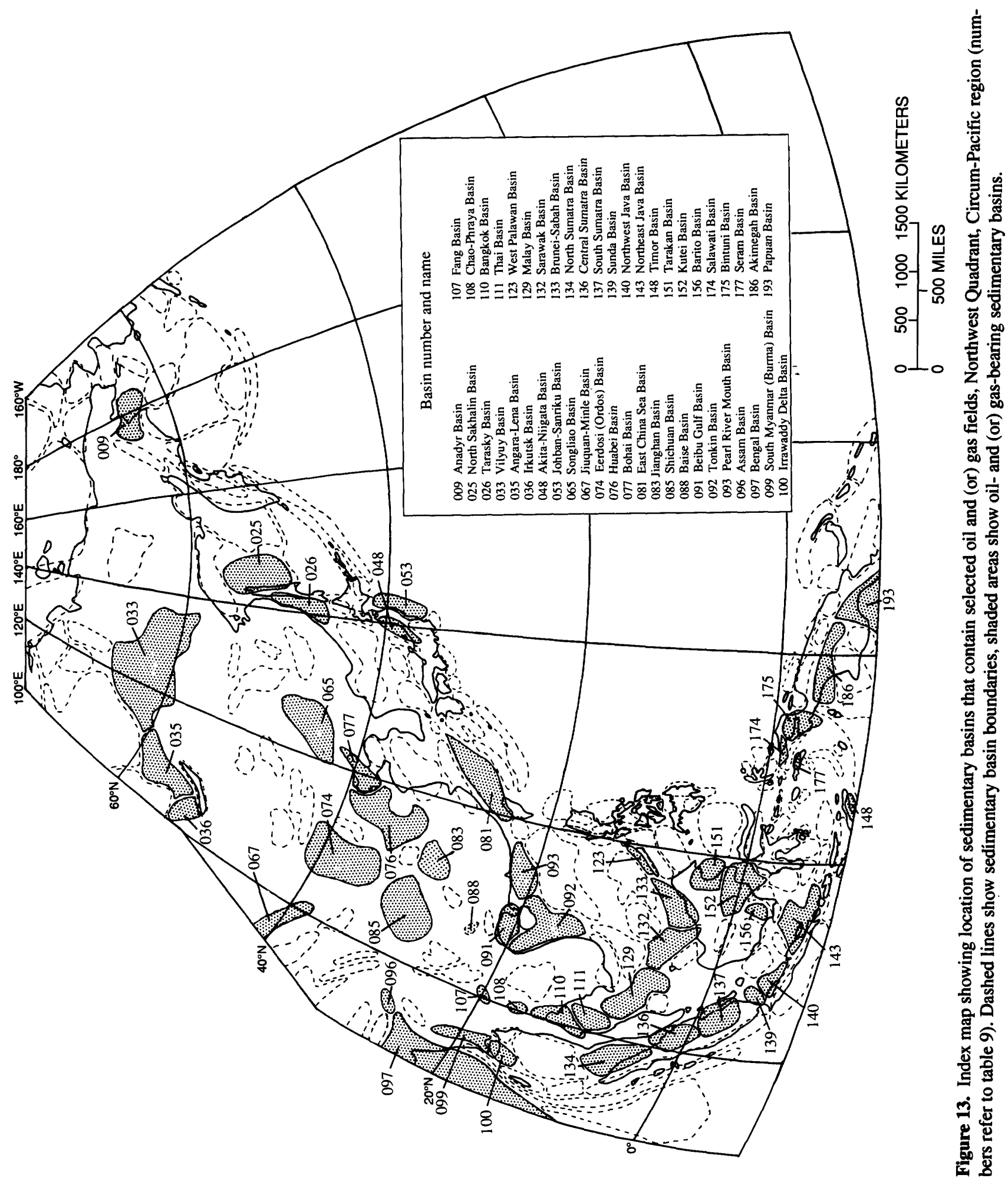




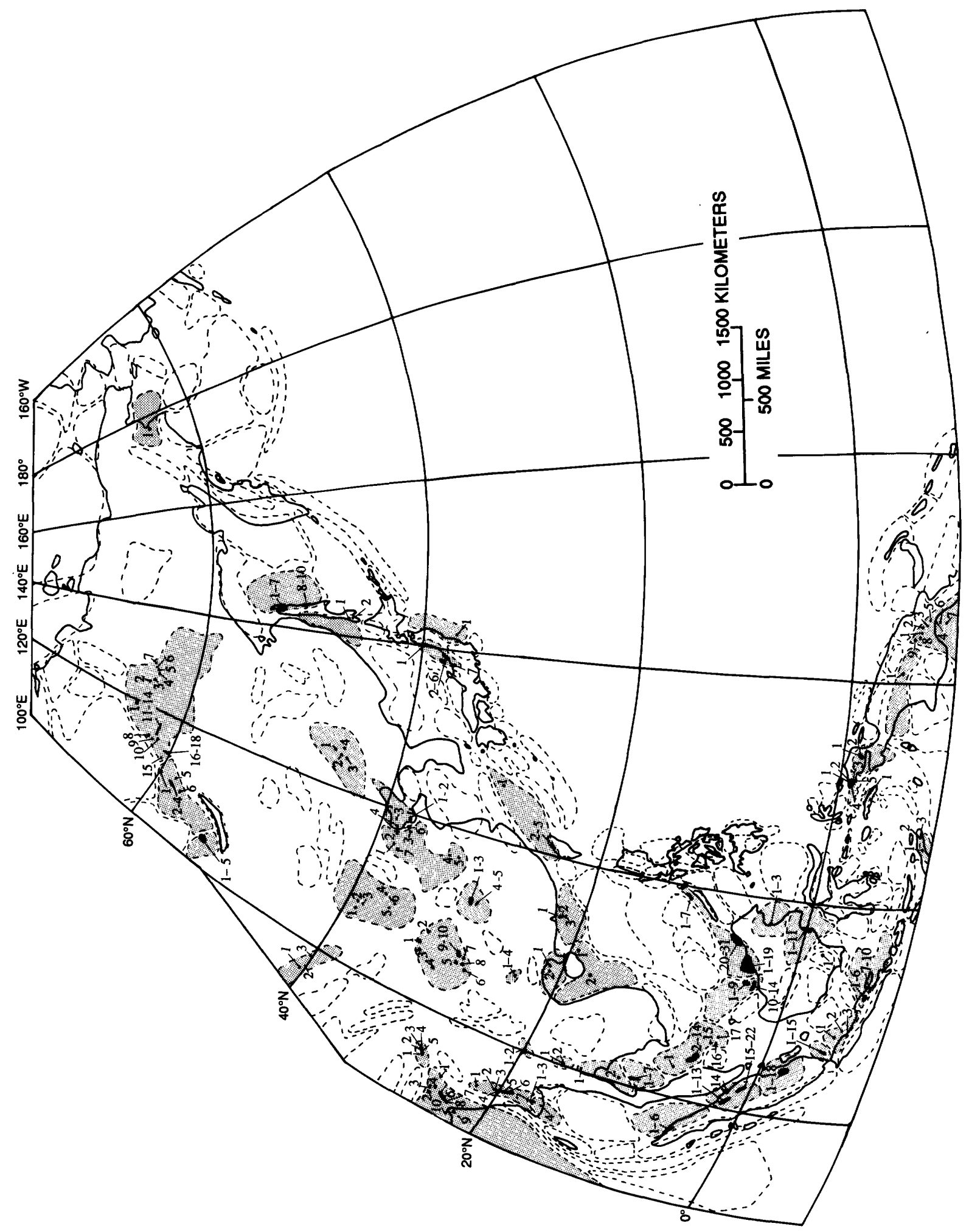

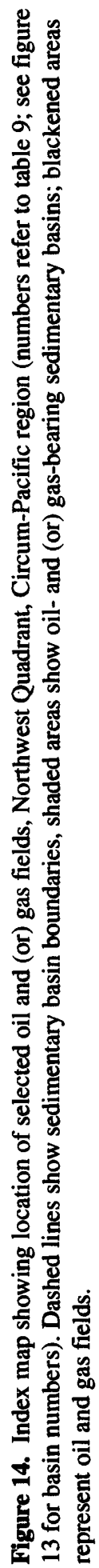




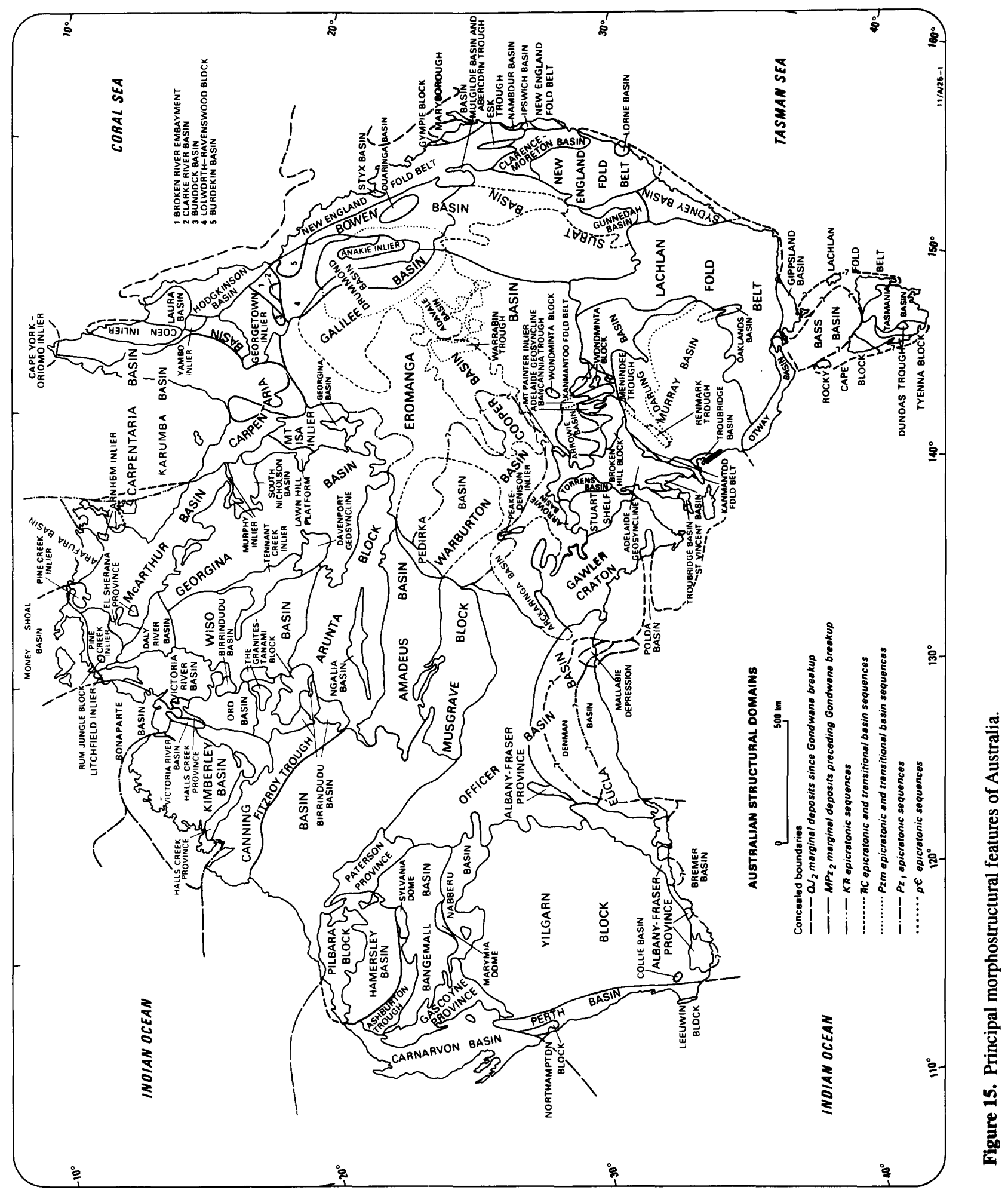




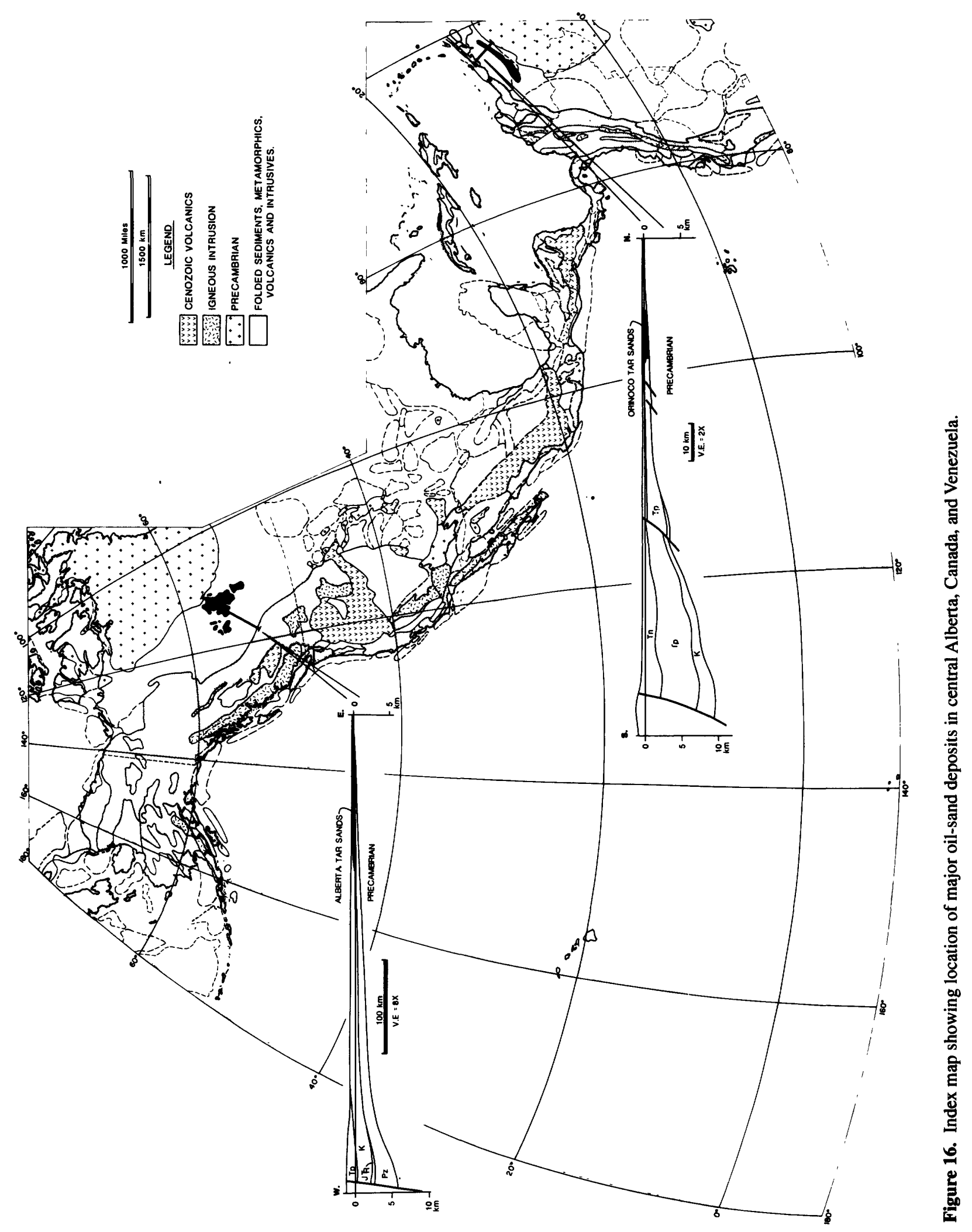




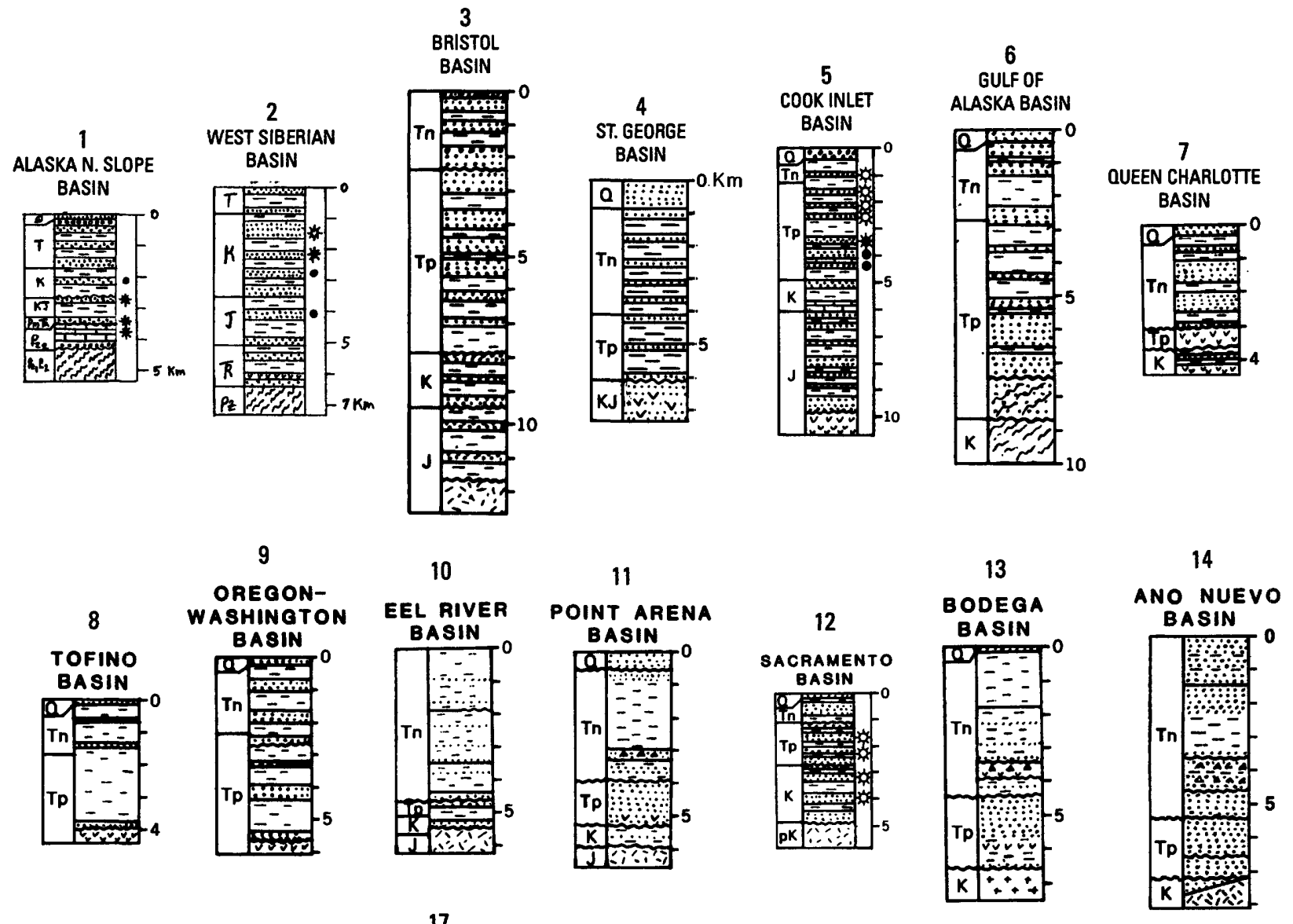

17

15

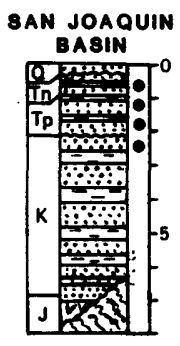

22

ATRATO

BASIN

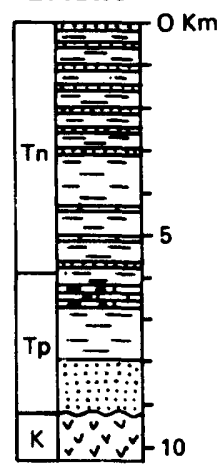

VENTURA

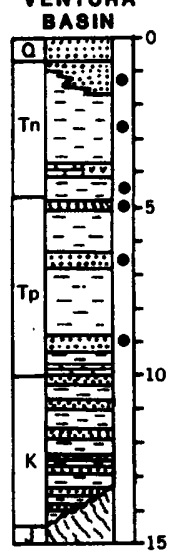

18

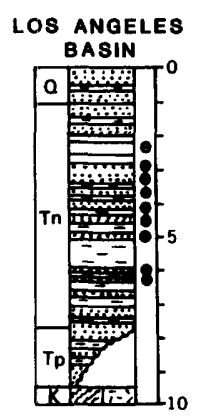

20

MIDDLE

AMERICA
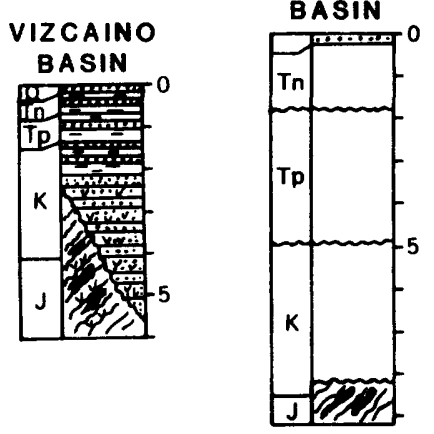

21

AZUERO

BASIN

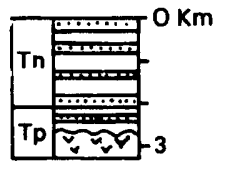

23

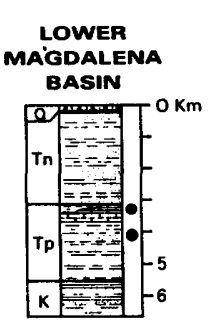

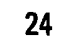

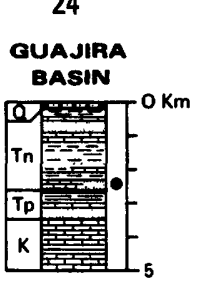

25

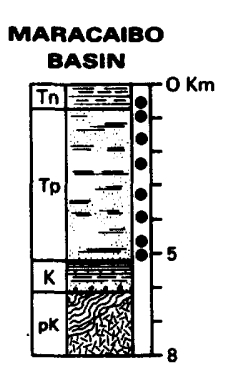

26

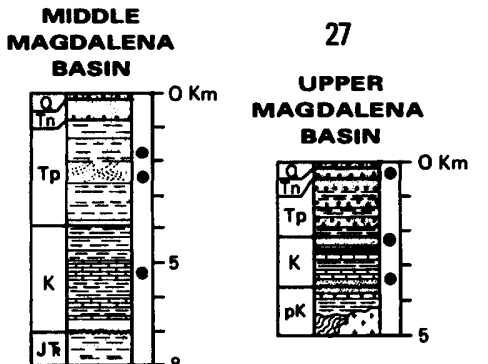

28

Barinas

APURE

BASIN

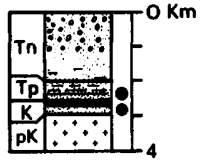

Figure 17. Stratigraphic columns of sedimentary basins, Circum-Pacific region. 


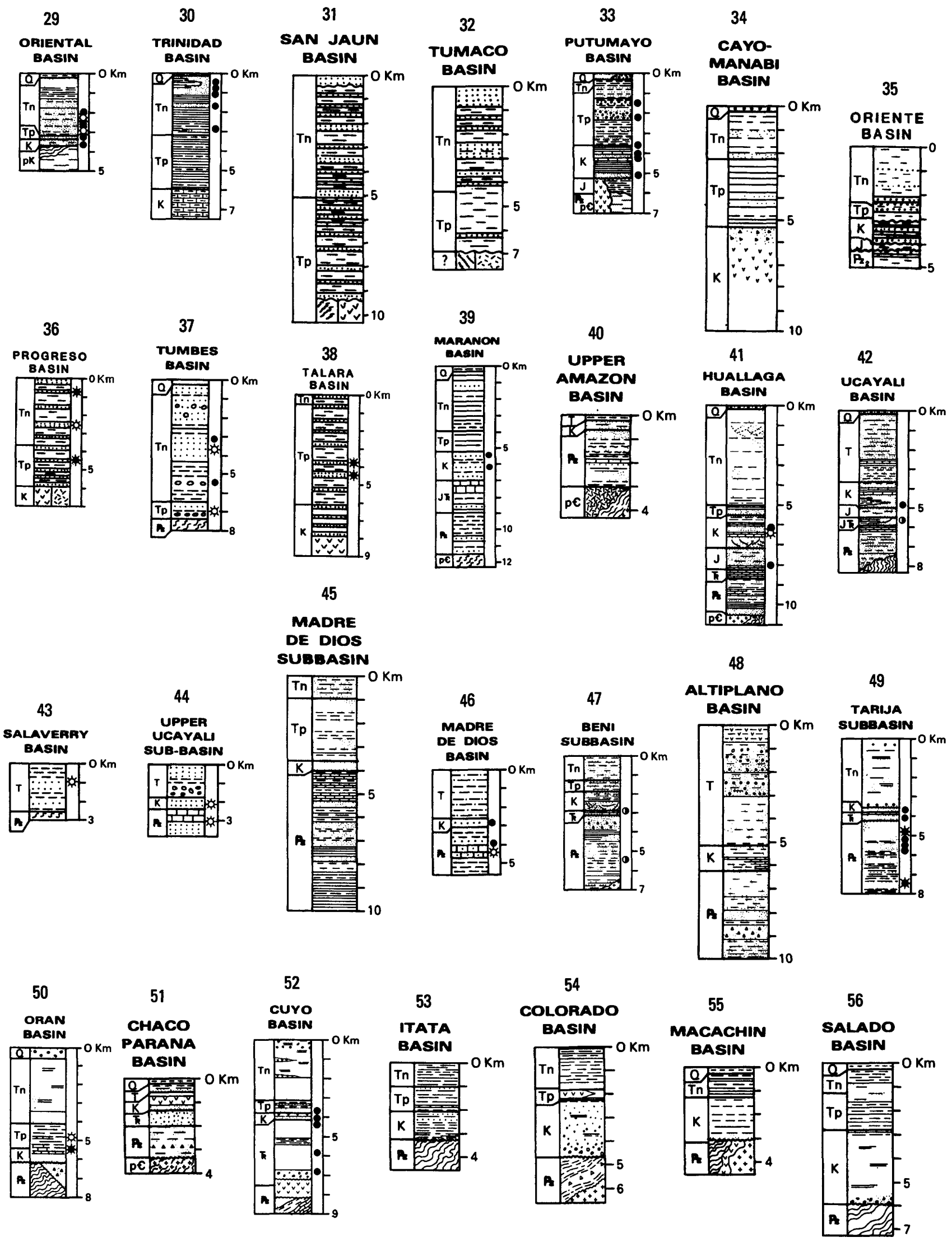

Figure 17. -continued Stratigraphic columns of sedimentary basins, Circum-Pacific region. 
57

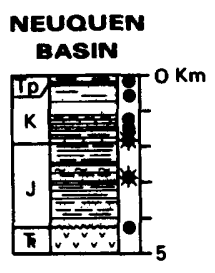

64

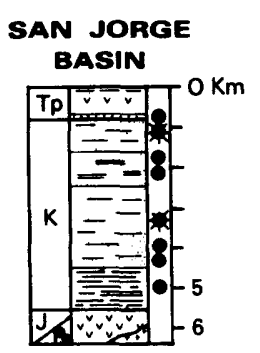

71

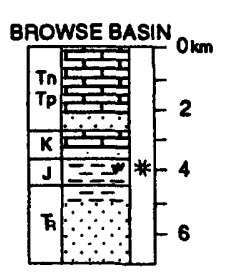

59

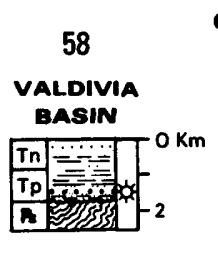

65

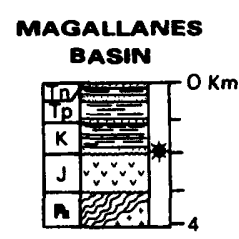

BASIN
66

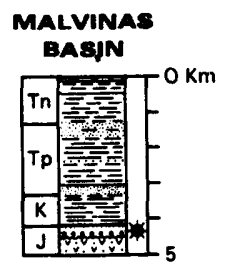

60

LLANOUIHUE

BASIN $0 \mathrm{~km}$
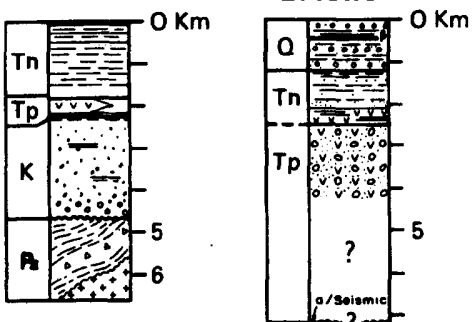

A.

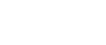

67

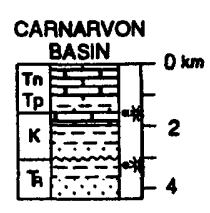

$$
74
$$

GREAT

AUSTAALIAN

BIGHT BASIN $0 \mathrm{~km}$

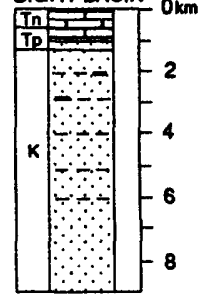

68

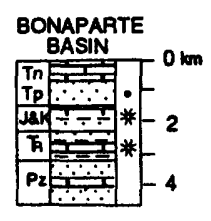

69
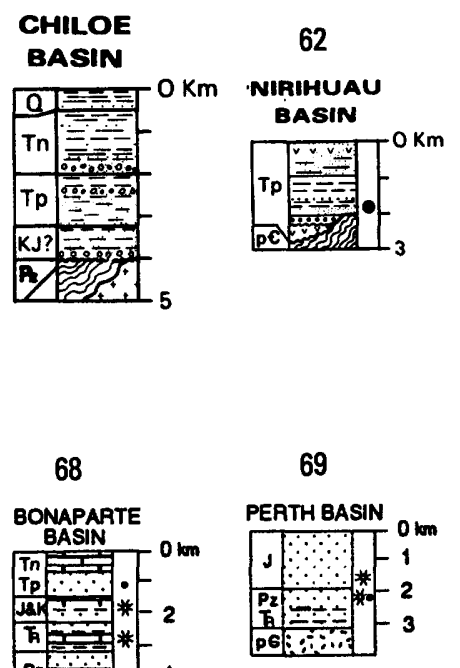

63

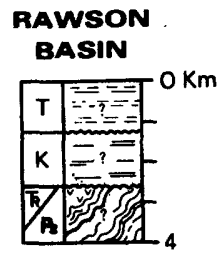

70

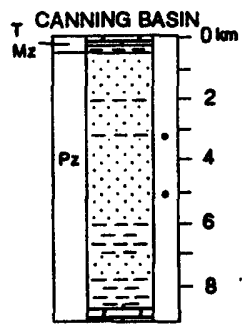

76

75

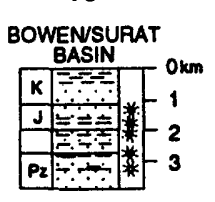

77

CLARENCE

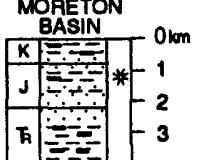

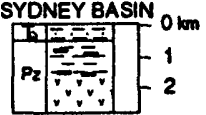

79

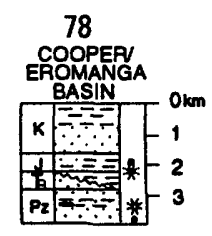

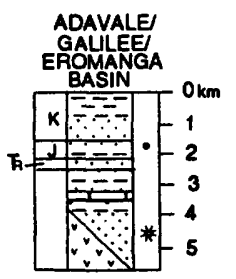

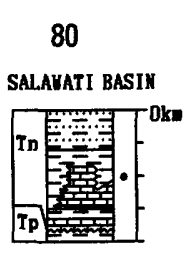

81

MORTHEAST JAVA BASIN

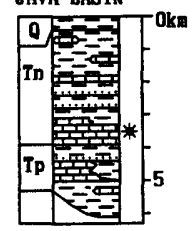

83

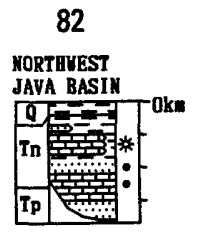

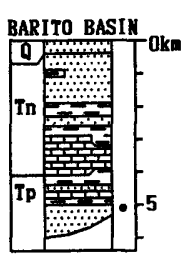

84

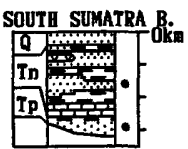

85

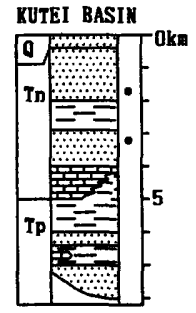

86

SARAUAK BASIN

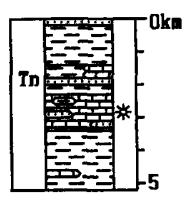

87
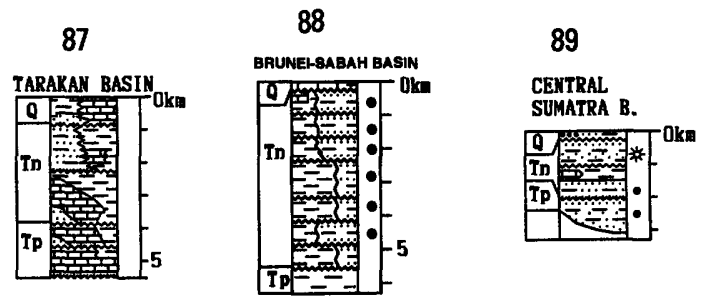

90

91

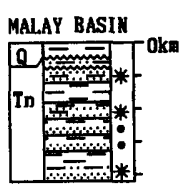

SIBOLGA BASIM

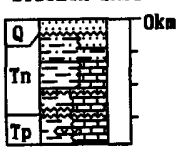

Figure 17. -continued Stratigraphic columns of sedimentary basins, Circum-Pacific region. 

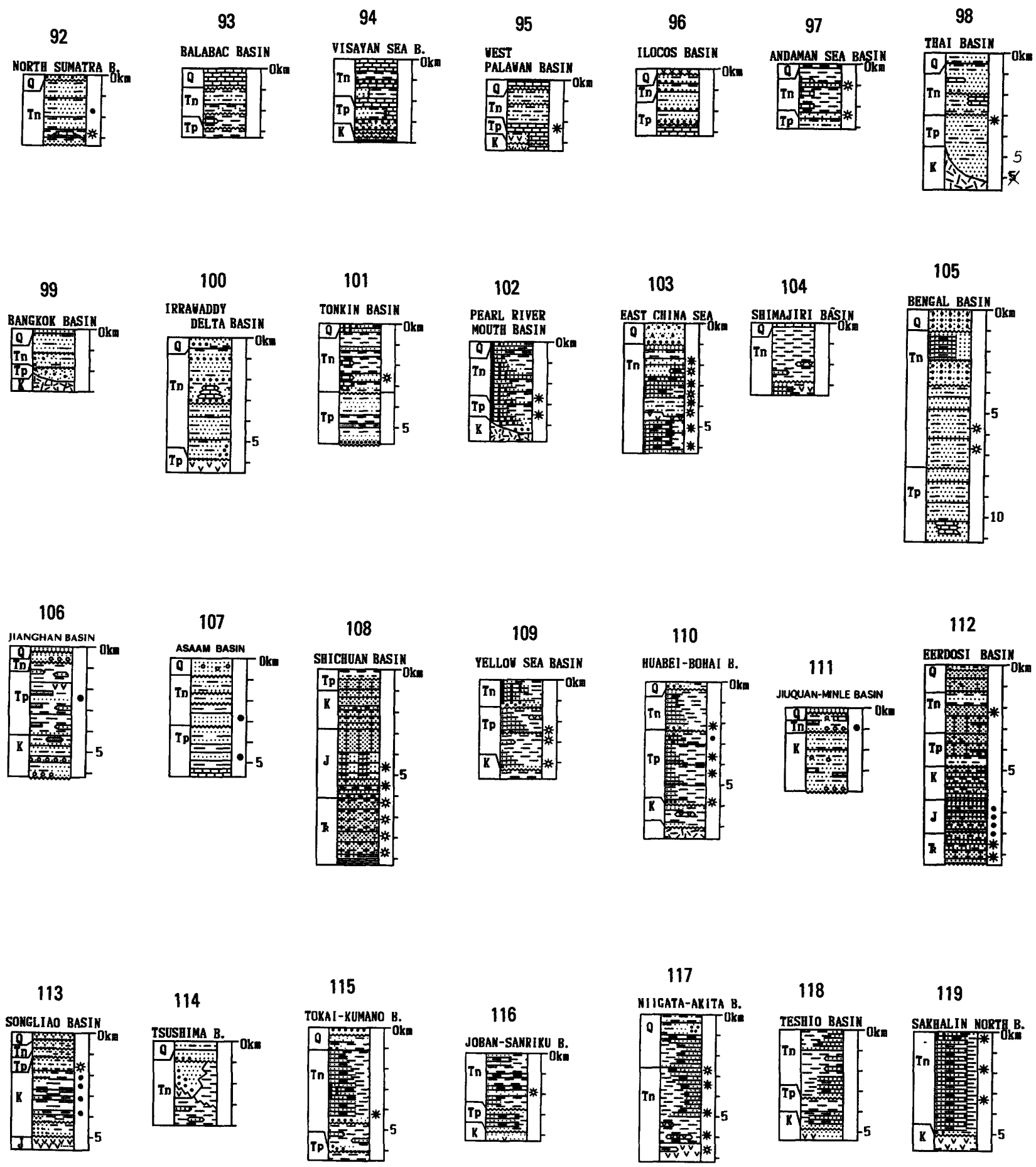

Figure 17. - continued Stratigraphic columns of sedimentary basins, Circum-Pacific region. 


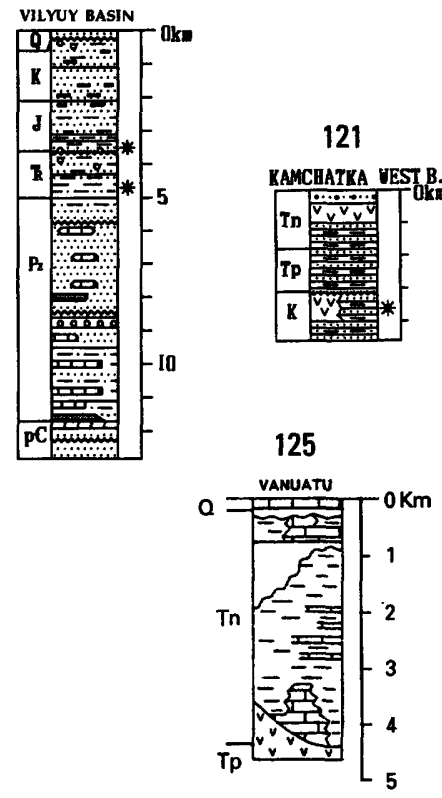

Age

$\begin{array}{ll}\text { Q Quatemary } & \text { pK Pre-Cretaceous } \\ \text { T Tertiary } & \text { J Jurassic } \\ \text { Tn Neogene } & \text { F Triassic } \\ \text { Tp Paleogene } & \text { P Paleozoic } \\ \text { K Cretaceous } & \text { pE Precambrian }\end{array}$

Symbol

* Gas-producing horizon

- Oil-producing horizon

* Oil- and gas-producing horizon

- Oil show
123
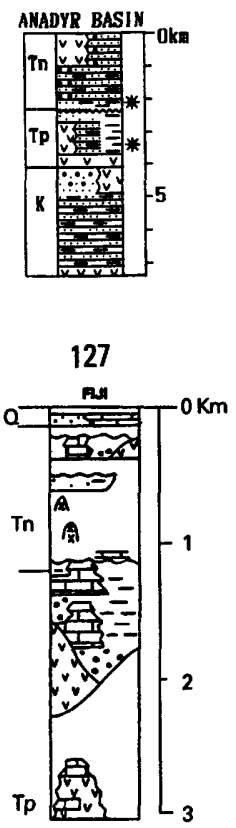

Tp

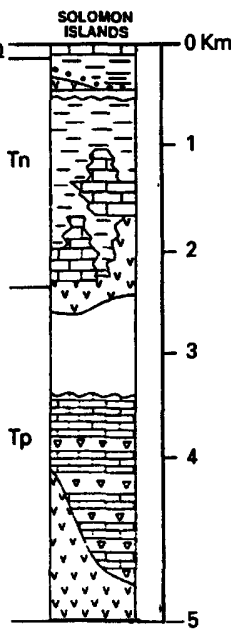

\section{EXPLANATION}

Lithologic Unit

$\because \vdots$ Sandstone

$==-$ Shale

$\because \because \because$ Conglomerate

iaid Chert

$\approx \approx \approx$ Gypsum

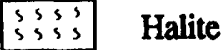

堅 Limestone

Erysy Metamorphic rock

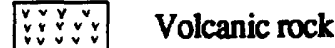

Undifferentiated igneous rock

Eéê Ultramafic rock

Figure 17.-continued Stratigraphic columns of sedimentary basins, Circum-Pacific region. 

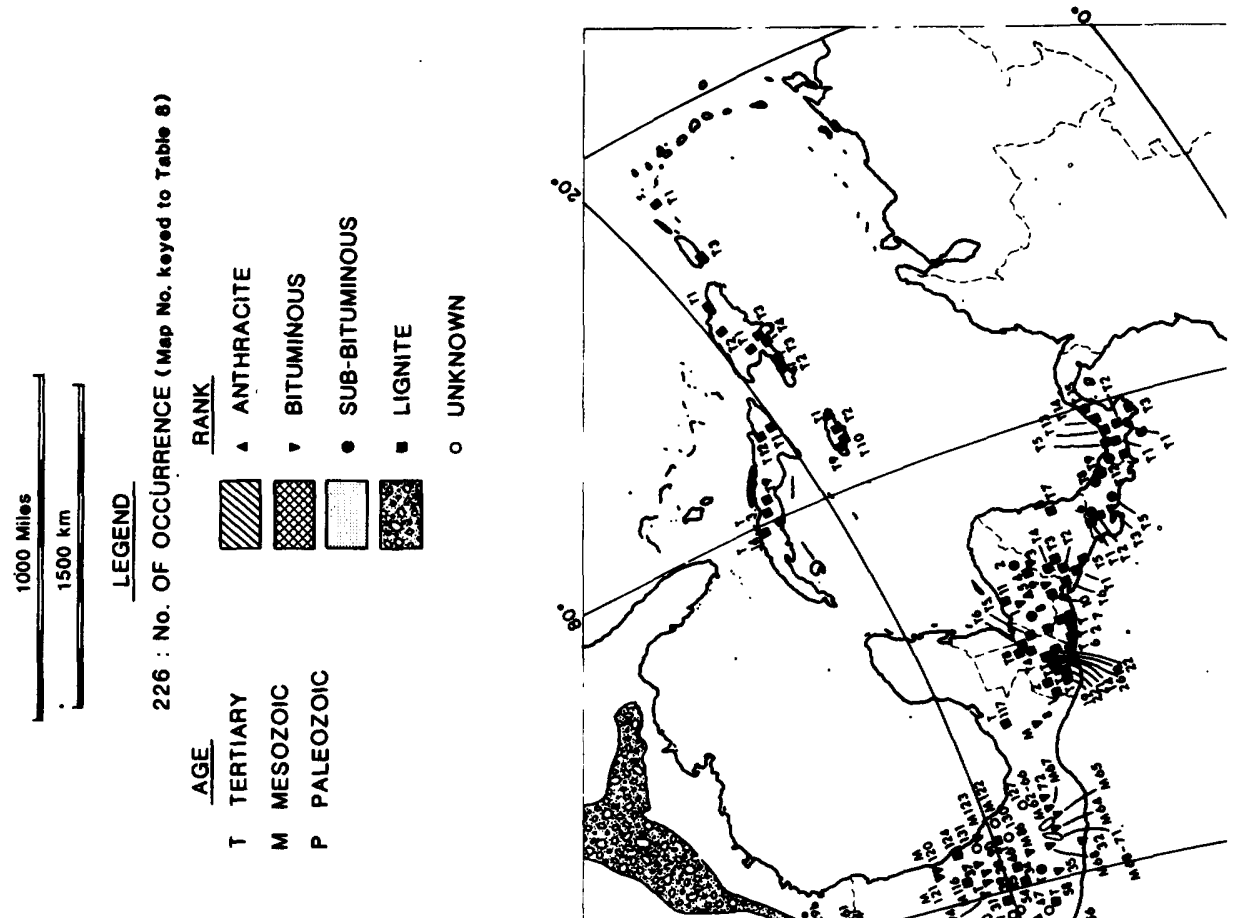

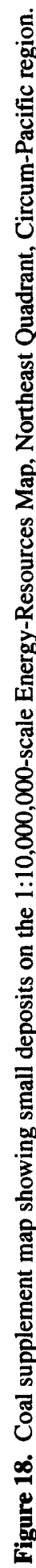




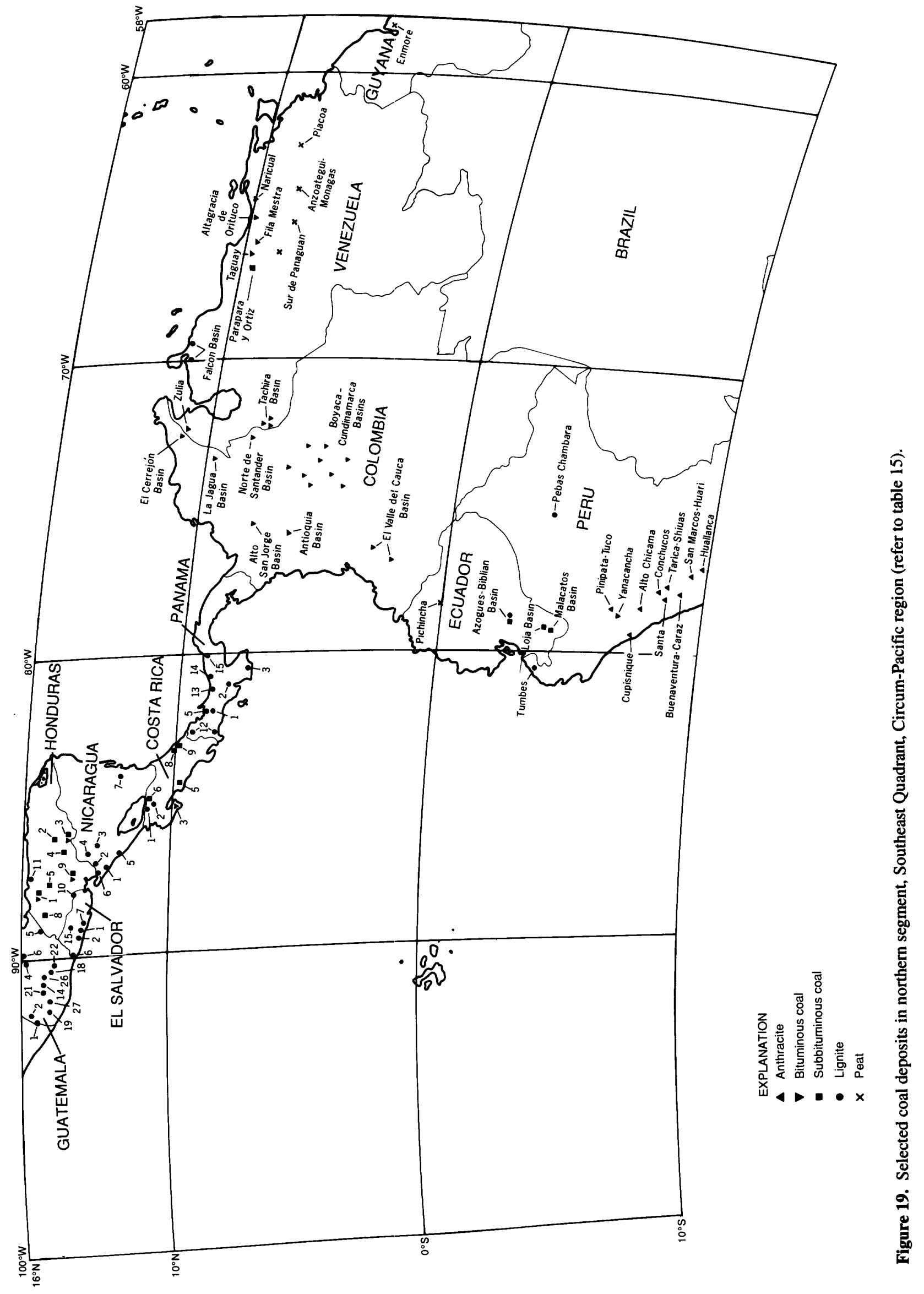




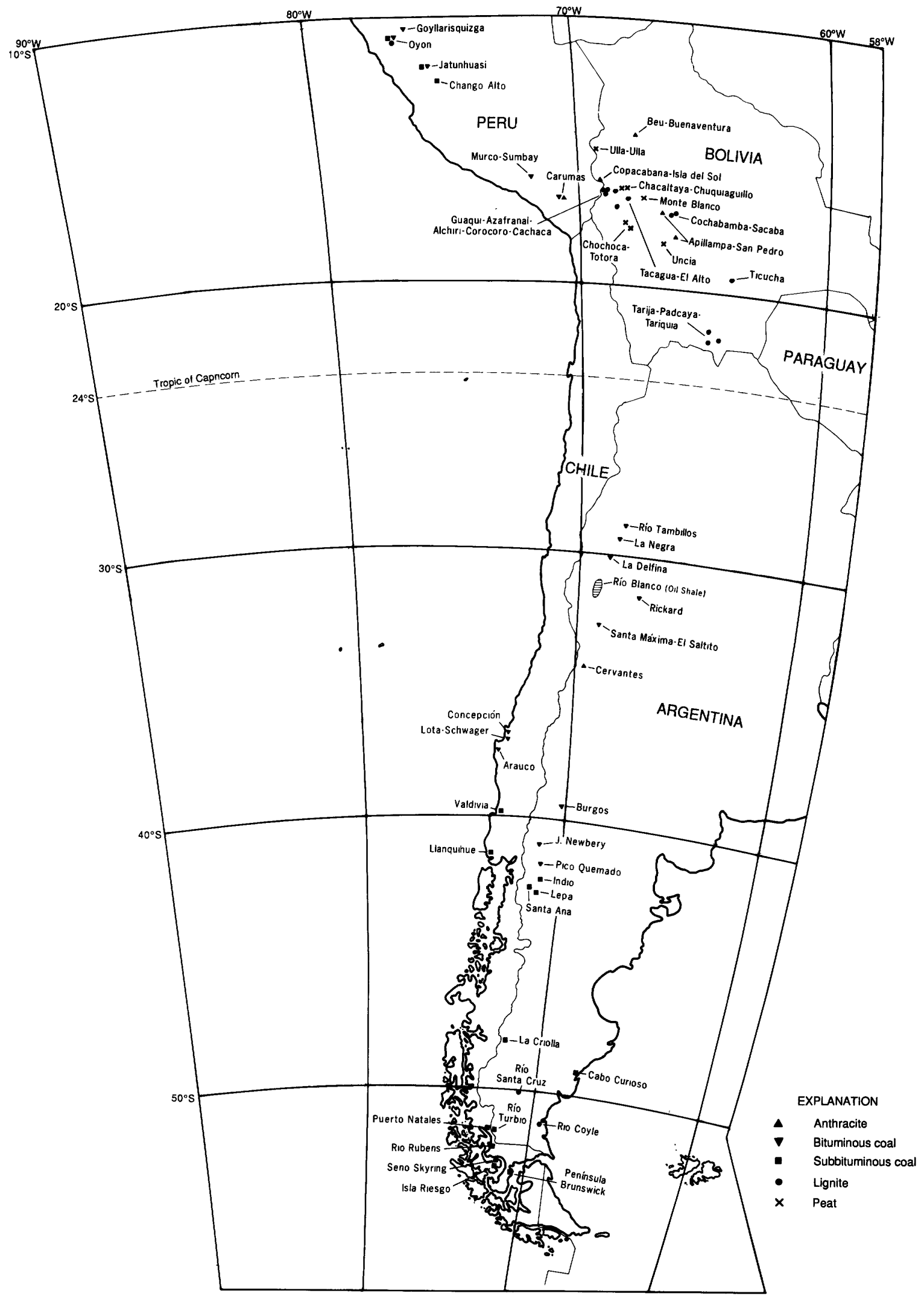

Figure 20. Selected coal deposits in southern segment, Southeast Quadrant, Circum-Pacific region (refer to table 15). 


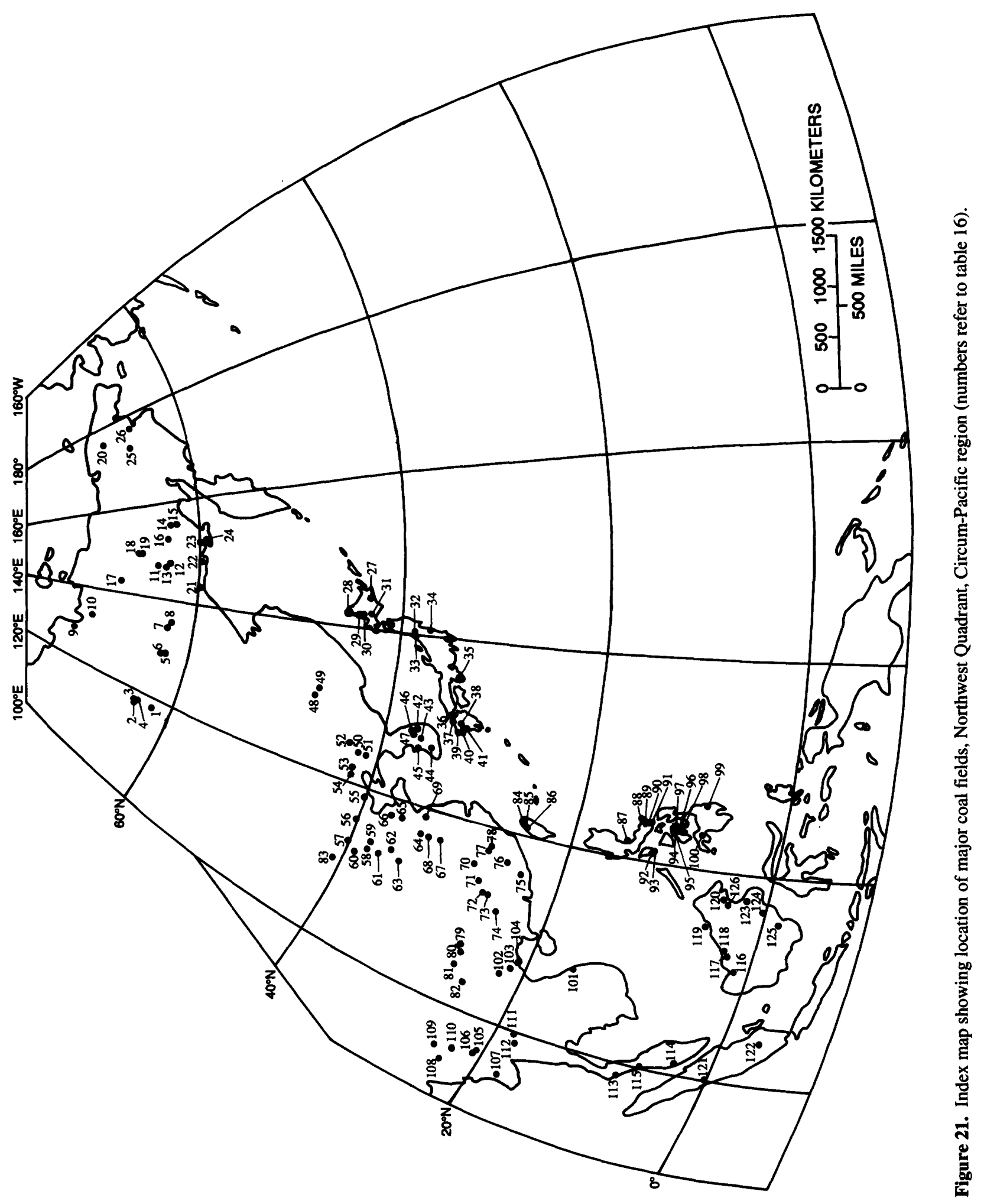




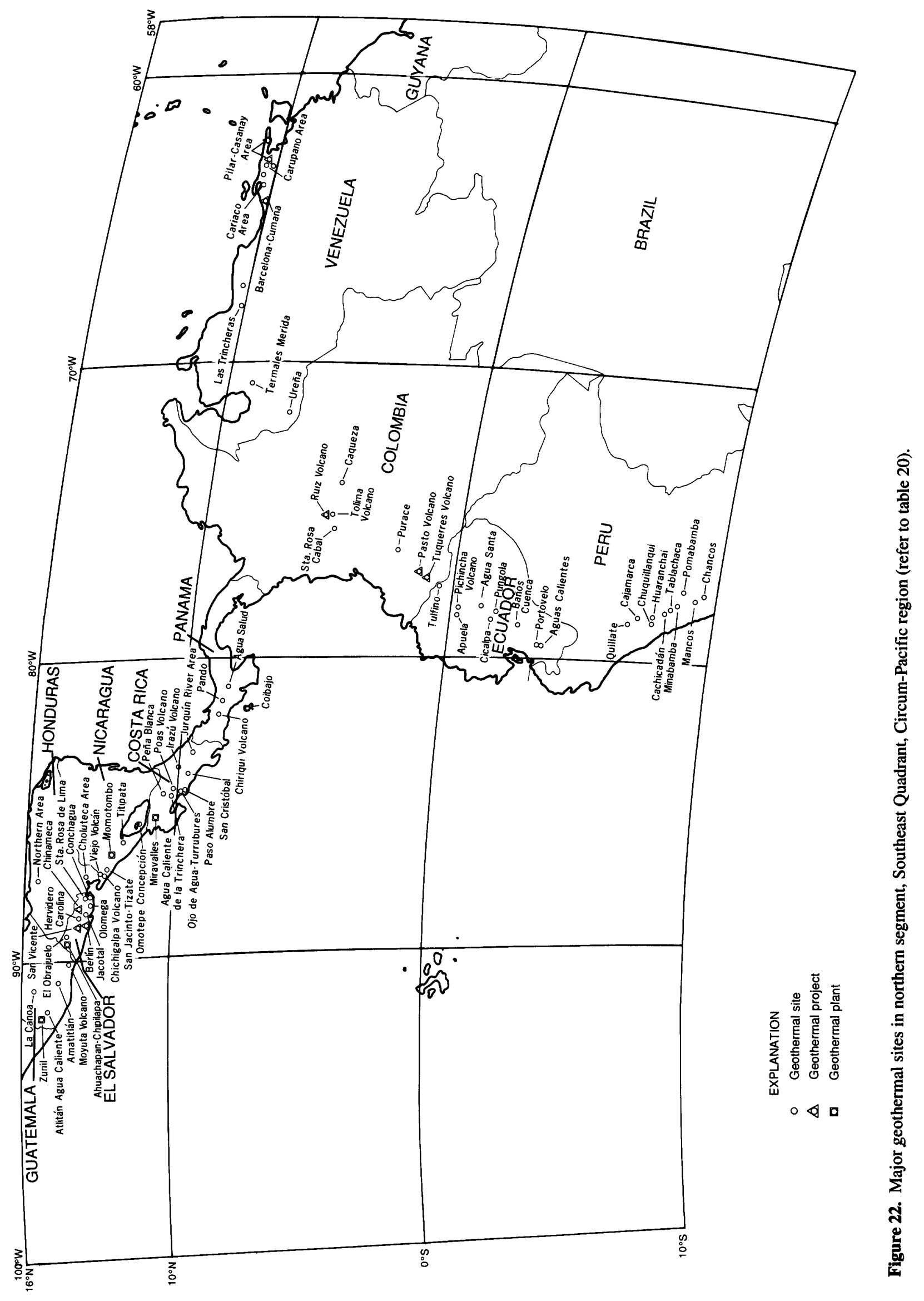




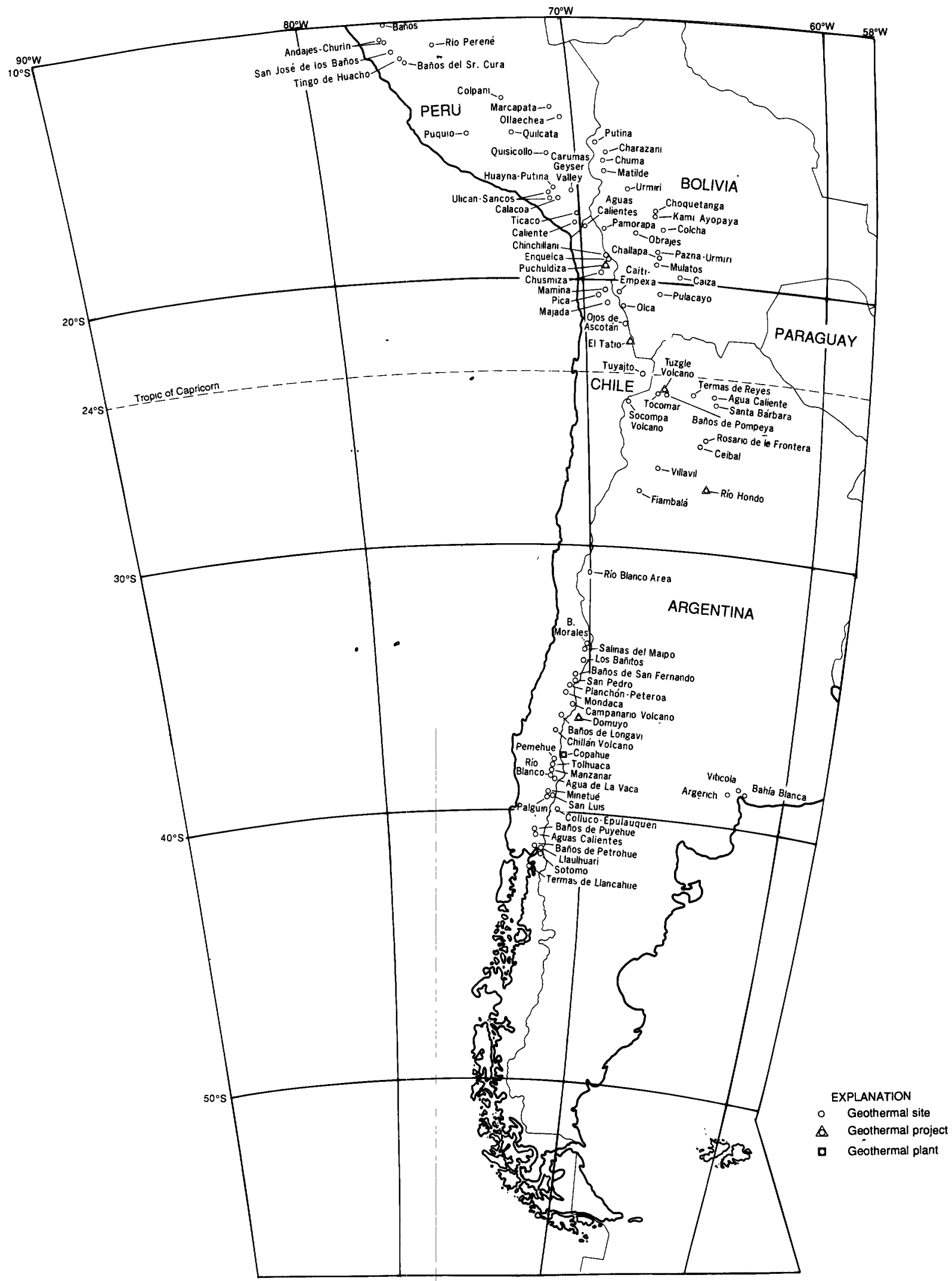

Figure 23. Major geothermal sites in southern segment, Southeast Quadrant, Circum-Pacific region (refer to table 20). 


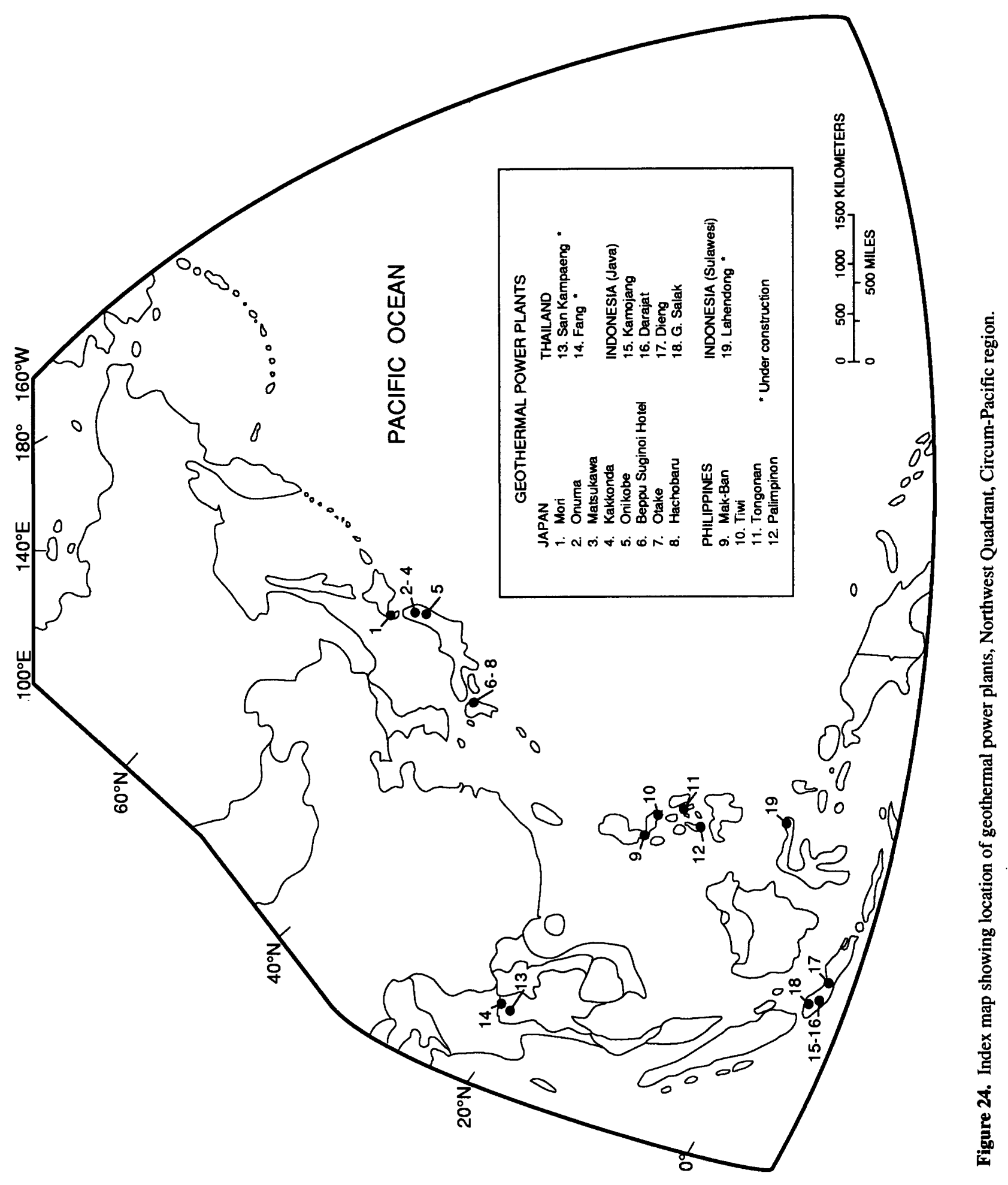


Table 1. Estimated initial and remaining oil and gas reserves by country, Circum-Pacific region

\begin{tabular}{|c|c|c|c|c|c|c|}
\hline \multirow[t]{3}{*}{ Country } & \multicolumn{2}{|c|}{ Initial Reserves } & \multicolumn{2}{|c|}{$\begin{array}{l}\text { Cum. Production } \\
\text { (as of } 12 / 31 / 98 \text { ) }\end{array}$} & \multicolumn{2}{|c|}{$\begin{array}{c}\text { Remaining Reserves } \\
\text { (as of 12/31/98) }\end{array}$} \\
\hline & Oil & Gas & Oil & Gas & Oil & Gas \\
\hline & (MMB) & (BCF) & (MMB) & (BCF) & (MMB) & $(B C F)$ \\
\hline Canada & 23,013 & 170,838 & $18,134.2$ & $108,810.6$ & $4,879.2$ & $62,027.1$ \\
\hline United States & 198,724 & $1,058,803$ & $177,689.5$ & $894,762.0$ & $21,034.0$ & $164,041.0$ \\
\hline Mexico & 50,094 & 59,318 & $25,393.6$ & $29,254.2$ & $24,700.1$ & $30,064.0$ \\
\hline Guatemala & 576 & 23 & 51.4 & 2.0 & 525.0 & 21.3 \\
\hline Cuba & 128 & 966 & 67.3 & 330.0 & 61.0 & 636.0 \\
\hline Barbados & 7 & 17 & 4.6 & 10.0 & 2.4 & 7.1 \\
\hline Argentina & 9,468 & 39,054 & $7,155.7$ & $15,961.4$ & $2,312.1$ & $23,092.2$ \\
\hline Bolivia & 520 & 8,600 & 393.4 & $3,293.4$ & 126.3 & $5,306.3$ \\
\hline Chile & 443 & 7,643 & 412.9 & $6,046.1$ & 29.9 & $1,597.2$ \\
\hline Colombia & 7,378 & 12,872 & $4,800.6$ & $4,349.5$ & $2,577.0$ & $8,522.0$ \\
\hline Ecuador & 6,765 & 1,402 & $2,663.3$ & 621.6 & $4,102.0$ & 780.9 \\
\hline Peru & 2,456 & 8,249 & $2,132.9$ & $1,253.3$ & 323.5 & $6,995.8$ \\
\hline Trinidad-Tobago & 3,537 & 27,130 & $2,942.6$ & $5,719.7$ & 594.0 & $21,409.8$ \\
\hline Venezuela & 125,369 & 173,861 & $50,297.8$ & $27,598.2$ & $75,071.0$ & $146,262.6$ \\
\hline FSU & 199,692 & $2,481,000$ & $133,051.2$ & $576,650.2$ & $66,641.1$ & $1,904,350.0$ \\
\hline China & 56,699 & 57,650 & $23,179.1$ & $15,289.6$ & $33,520.0$ & $42,360.0$ \\
\hline Japan & 328 & 3,997 & 267.5 & $2,617.0$ & 60.2 & $1,380.0$ \\
\hline Taiwan & 21 & 2,700 & 16.9 & & 4.0 & $2,700.0$ \\
\hline Vietnam & 2,425 & 6,183 & 427.8 & 183.1 & $1,997.1$ & $6,000.0$ \\
\hline Myanmar & 651 & 15,563 & 470.8 & 563.3 & 180.0 & $15,000.0$ \\
\hline Thailand & 646 & 19,035 & 257.3 & $4,210.0$ & 388.4 & $14,825.1$ \\
\hline Philippines & 349 & 3,500 & 42.9 & & 306.0 & $3,500.0$ \\
\hline Indonesia & 26,523 & 106,194 & $17,885.7$ & $29,128.5$ & $8,637.3$ & $77,065.7$ \\
\hline Malaysia & 8,642 & 94,556 & $3,996.9$ & $8,725.2$ & $4,645.0$ & $85,831.0$ \\
\hline Brunei & 3,953 & 16,439 & $2,933.3$ & $6,859.2$ & $1,020.0$ & $9,580.0$ \\
\hline Papua New Guinea & 567 & 5,465 & 233.6 & 23.1 & 333.0 & $5,442.0$ \\
\hline Australia & 6,682 & 43,039 & $4,909.7$ & $14,628.6$ & $1,772.0$ & $28,410.0$ \\
\hline New Zealand & 329 & 5,364 & 219.1 & $3,131.2$ & 110.0 & $2,233.0$ \\
\hline Total & 735,983 & $4,429,461$ & 480,032 & $1,760,021.0$ & $255,951.6$ & $2,669,440.2$ \\
\hline
\end{tabular}

Data Sources: $\quad$ World Oil, Oil Gas Journal, Olade, Pemex, APEC, CAPP, EIA 
Table 2. Oil and gas production in 1998 by country, Circum-Pacific region

\begin{tabular}{|c|c|c|c|c|}
\hline \multirow[t]{3}{*}{ Country } & \multicolumn{2}{|c|}{ Yearly production } & \multicolumn{2}{|c|}{ Daily production } \\
\hline & Oil & Gas & Oil & Gas \\
\hline & (MMB) & (BCF) & (MB) & (MMCF) \\
\hline Canada & 793.4 & $6,893.8$ & $2,173.6$ & $18,887.1$ \\
\hline United States & $2,282.0$ & $19,622.0$ & $6,252.0$ & $53,758.9$ \\
\hline Mexico & $1,120.7$ & $1,748.7$ & $3,070.5$ & $4,791.0$ \\
\hline Guatemala & 9.3 & 0.4 & 25.5 & 1.1 \\
\hline Cuba & 11.5 & 0.9 & 31.5 & 2.3 \\
\hline Barbados & 0.6 & 1.3 & 1.6 & 3.6 \\
\hline Argentina & 309.3 & $1,374.4$ & 847.3 & $3,765.5$ \\
\hline Bolivia & 13.7 & 222.2 & 37.4 & 608.8 \\
\hline Chile & 3.0 & 100.9 & 8.1 & 276.4 \\
\hline Colombia & 267.4 & 279.3 & 732.5 & 765.2 \\
\hline Ecuador & 137.1 & 54.0 & 375.5 & 147.8 \\
\hline Peru & 42.2 & 39.4 & 115.6 & 107.8 \\
\hline Trinidad-Tobago & 44.7 & 365.3 & 122.6 & $1,001.0$ \\
\hline Venezuela & $1,138.8$ & $1,565.2$ & $3,120.0$ & $4,288.3$ \\
\hline Russia & $2,160.4$ & $23,491.0$ & $5,919.0$ & $64,358.9$ \\
\hline China & $1,168.0$ & 766.6 & $3,199.9$ & $2,100.4$ \\
\hline Japan & 5.0 & 60.0 & 13.7 & 164.4 \\
\hline Taiwan & 0.3 & 30.0 & 0.9 & 82.2 \\
\hline Vietnam & 82.6 & 38.7 & 226.4 & 105.9 \\
\hline Myanmar & 3.7 & 51.0 & 10.0 & 139.7 \\
\hline Thailand & 30.5 & 576.9 & 83.5 & $1,580.7$ \\
\hline Philippines & 0.3 & 0.3 & 0.8 & 0.9 \\
\hline Indonesia & 470.5 & $2,421.7$ & $1,289.0$ & $6,634.8$ \\
\hline Malaysia & 266.9 & 847.1 & 731.2 & $2,320.7$ \\
\hline Brunei & 49.5 & 348.3 & 135.6 & 954.3 \\
\hline Papua New Guinea & 28.9 & 4.9 & 79.1 & 13.3 \\
\hline Australia & 216.0 & $1,072.3$ & 591.9 & $2,937.7$ \\
\hline New Zealand & 16.0 & 168.3 & 43.7 & 461.0 \\
\hline Total & $10,672.0$ & $62,144.8$ & $29,238.4$ & $170,259.8$ \\
\hline
\end{tabular}

Data Sources: $\quad$ EIA, CAPP, Pemex, OLADE, APEC, OGJ 
Table 3. Coal production in 1996 by country, Circum-Pacific region

Country
United States
Mexico
Argentina
Chile
Colombia
Peru
Venezuela
Russia
China
Japan
North Korea
South Korea
Taiwan
Vietnam
Myanmar
Thailand
Philippines
Indonesia
Malaysia
Australia
New Zealand

$\begin{array}{rr} & \\ \text { Anthracite } & 0 \\ 4,751 \\ 0 \\ 0 \\ 0 \\ 0 \\ 10 \\ 0 \\ 21,104 \\ 296,939 \\ 183 \\ 50,548 \\ 5,458 \\ 0 \\ 10,828 \\ 0 \\ 6 \\ 0 \\ 0 \\ 0 \\ 0 \\ 145 \\ \\ \text { Total } \\ 389,971 \\ \end{array}$

Yearly production

(Thousand Short Tons)

\begin{tabular}{|rrr|} 
Bituminous & Lignite & \multicolumn{1}{c}{ Total } \\
\hline 71,601 & 11,964 & 83,565 \\
971,048 & 88,056 & $1,063,856$ \\
10,097 & 0 & 10,097 \\
342 & 0 & 342 \\
1,190 & 42 & 1,232 \\
33,141 & 0 & 33,141 \\
59 & 0 & 69 \\
3,843 & 0 & 3,843 \\
183,535 & 99,428 & 304,067 \\
$1,170,160$ & 72,499 & $1,539,597$ \\
7,143 & 18 & 7,344 \\
0 & 28,109 & 78,657 \\
0 & 0 & 5,458 \\
163 & 0 & 163 \\
0 & 0 & 10,828 \\
34 & 45 & 79 \\
0 & 23,671 & 23,677 \\
1,239 & 3 & 1,242 \\
55,482 & 0 & 55,482 \\
91 & 0 & 91 \\
213,170 & 59,088 & 272,259 \\
3,156 & 353 & 3,654 \\
& & \\
\hline $2,725,494$ & $1,068,413$ & $7,467,106$
\end{tabular}

Data Source: EIA World Energy database 
Table 4. Selected giant and major oil fields, Northeast Quadrant, Circum-Pacific region

\begin{tabular}{cl} 
Map & \multicolumn{1}{c}{ Field, } \\
No. & \multicolumn{1}{c}{ Year Discovered } \\
& \multicolumn{1}{c}{ Canada } \\
& \multicolumn{1}{c}{ Pembina, 1953 } \\
1 & Swan Hills, 1957 \\
2 & Redwater, 1948 \\
4 & Rainbow, 1965 \\
5 & Bonnie Glen, 1952 \\
6 & Swan Hills-S., 1959 \\
& \multicolumn{1}{c}{ Totals } \\
& \multicolumn{1}{c}{ Colombia } \\
& Cano-Limon, 1983 \\
2 & La Cira, 1925 \\
3 & Casabe, 1941 \\
4 & Infantas, 1918
\end{tabular}

\section{Totals}

Ecuador

$\begin{array}{ll}1 & \text { Shushufindi, } 1959 \\ 2 & \text { Sacha, } 1969 \\ 3 & \text { Ancon, } 1921\end{array}$

Totals

Peru

1 La Brea-Parinas, 1869 Talara

\section{Trinidad}

1 Soldado, 1955

2 Fyzabad-Forrest

Reserve, 1913

Totals

Llanos
Mid.
Mid.
Mid.

Napo
Napo
Daule

Daule

Paria

Paria

W. Canada
W. Canada
W. Canada
W. Canada
W. Canada
W. Canada

Cretaceous

Devonian

Devonian

Devonian

Devonian

Devonian
Major Reservoir

$$
\text { Age }
$$

Cretaceous
Cretaceous
Tertiary

Tertiary

Tertiary

Tertiary taceous

Tertiary-

Cretaceous

Sandstone

Sandstone

Sandstone

Sandstone

Sandstone
Lithology

Sandstone

Carbonate

Carbonate

Carbonate

Carbonate

Carbonate

Sandstone

Sandstone

7500

3250

Sandstone

3800

Sandstone

2000

4000

2600

5500

5000

8000

Cum. Prod. Est. Ult.

12/31/84 Recovery

(MMB)

(MMB)

890.5

2065.0

9700

392.1

290.1

800.0

9700

650.0

4000

115.9

135.0

798.1

1585.0

5500

910.7

1100.0

Sandstone $\quad 11000$

421.4

650.0

8000

420.4

600.0

841.8

1250.0 
Table 4.-continued Selected giant and major oil fields, Northeast Quadrant, Circum-Pacific region

\begin{tabular}{|c|c|c|c|c|c|c|c|}
\hline $\begin{array}{l}\text { Map } \\
\text { No. }\end{array}$ & $\begin{array}{c}\text { Field, } \\
\text { Year Discovered }\end{array}$ & Basin & Age & Lithology & $\begin{array}{l}\text { Depth } \\
\text { (Feet) }\end{array}$ & $\begin{array}{l}\text { Cum. Prod. } \\
\text { 12/31/84 } \\
\text { (MMB) }\end{array}$ & $\begin{array}{l}\text { Recovery } \\
\text { (MMB) }\end{array}$ \\
\hline 1 & $\begin{array}{r}\text { Mexico } \\
\text { Cantarell, } 1976\end{array}$ & Campeche & $\begin{array}{l}\text { Jurassic, Creta- } \\
\text { ceous, Tertiary }\end{array}$ & $\begin{array}{l}\text { Carbonate, } \\
\text { Sandstone }\end{array}$ & 8500 & 1644.4 & 9000.0 \\
\hline 2 & A.J. Bermudez, 1973 & Reforma & $\begin{array}{l}\text { Jurassic, Creta- } \\
\text { ceous, Tertiary }\end{array}$ & $\begin{array}{l}\text { Carbonate, } \\
\text { Sandstone }\end{array}$ & 12200 & 1501.8 & 5800.0 \\
\hline 3 & Poza Rica, 1930 & Tampico & Cretaceous & Carbonate & 7100 & 875.1 & 1800.0 \\
\hline 4 & $\begin{array}{l}\text { Naranjos-C. Azul, } \\
1909\end{array}$ & Tampico & Cretaceous & Carbonate & 1800 & 1208.2 & 1400.0 \\
\hline 5 & Sitio Grande, 1972 & Reforma & Cretaceous & Carbonate & 13700 & 261.1 & 1150.0 \\
\hline 6 & Cactus-Nispero, 1972 & Reforma & Cretaceous & Carbonate & 15000 & 366.7 & 1100.0 \\
\hline 7 & Ebano-Panuco, 1901 & Tampico & Cretaceous & Carbonate & 1450 & 940.3 & 1050.0 \\
\hline 8 & Abkatun, 1978 & Campeche & $\begin{array}{l}\text { Cretaceous, } \\
\text { Tertiary }\end{array}$ & Carbonate & 10200 & 477.6 & n.a. \\
\hline 9 & Ku, 1979 & Campeche & $\begin{array}{l}\text { Jurassic, } \\
\text { Cretaceous }\end{array}$ & $\begin{array}{l}\text { Carbonate, } \\
\text { Sandstone }\end{array}$ & 10000 & 203.3 & n.a. \\
\hline & Totals & & & & & 7478.5 & 21300.0 \\
\hline 1 & $\begin{array}{l}\text { Venezuela } \\
\text { Bolivar Coastal, } \\
1917\end{array}$ & Maracaibo & Tertiary & Sandstone & 4530 & 24408.4 & 32000.0 \\
\hline 2 & Lamar, 1958 & Maracaibo & $\begin{array}{l}\text { Tertiary, } \\
\text { Cretaceous }\end{array}$ & Sandstone & 12500 & 1038.4 & 1650.0 \\
\hline 3 & Centro, 1959 & Maracaibo & Tertiary & Sandstone & 10000 & 725.5 & 1200.0 \\
\hline 4 & Oficina, 1917 & E. Venezuela & Tertiary & Sandstone & 5000 & 767.9 & 1100.0 \\
\hline 5 & Boscan, 1946 & Maracaibo & Tertiary & Sandstone & 7000 & 687.9 & 1100.0 \\
\hline 6 & La Paz, 1925 & Maracaibo & $\begin{array}{l}\text { Tertiary, } \\
\text { Cretaceous }\end{array}$ & $\begin{array}{l}\text { Sandstone, } \\
\text { Carbonate }\end{array}$ & 6000 & 842.0 & 1050.0 \\
\hline 7 & Urdaneta, 1970 & Maracaibo & $\begin{array}{l}\text { Tertiary, } \\
\text { Cretaceous }\end{array}$ & $\begin{array}{l}\text { Sandstone, } \\
\text { Carbonate }\end{array}$ & 10000 & 87.7 & 1000.0 \\
\hline 8 & Quiriquire, 1928 & E. Venezuela & $\begin{array}{l}\text { Tertiary, } \\
\text { Cretaceous . }\end{array}$ & Sandstone & 3000 & 758.2 & 820.0 \\
\hline 9 & Mene Grande, 1914 & Maracaibo & Tertiary & Sandstone & 2750 & 627.9 & 800.0 \\
\hline 10 & Guara, 1946 & E. Venezuela & Tertiary & Sandstone & 7500 & 555.0 & 700.0 \\
\hline 11 & Nipa, 1945 & E. Venezuela & Tertiary & Sandstone & 7200 & 498.8 & 675.0 \\
\hline 12 & Greater Jusepin, 1938 & E. Venezuela & Tertiary & Sandstone & 6000 & 557.0 & 600.0 \\
\hline 13 & Mata, 1954 & E. Venezuela & Tertiary & Sandstone & 9500 & 499.8 & 600.0 \\
\hline 14 & Mara, 1945 & Maracaibo & Tertiary & Sandstone & 5200 & 405.0 & 500.0 \\
\hline 15 & Santa Rosa, 1941 & E. Venezuela & Tertiary & Sandstone & 8500 & 380.4 & 500.0 \\
\hline 16 & $\begin{array}{r}\text { Chimire, } 1948 \\
\text { Totals }\end{array}$ & E. Venezuela & Tertiary & Sandstone & 7100 & $\begin{array}{r}365.8 \\
33205.7\end{array}$ & $\begin{array}{r}500.0 \\
44795.0\end{array}$ \\
\hline
\end{tabular}


Table 4. - continued Selected giant and major oil fields, Northeast Quadrant, Circum-Pacific region

$\begin{array}{cccccccc}\text { Map } & \text { Field, } & & \text { Major Reservoir } & & \text { Cum. Prod. } & \text { Est. Ult. } \\ \text { No. } & \text { Year Discovered } & \text { Basin } & \text { Age } & \text { Lithology } & \begin{array}{l}\text { Depth } \\ \text { (Feet) }\end{array} & \text { (MMB) } & \text { (MMB) }\end{array}$

United States

\begin{tabular}{|c|c|c|c|c|c|c|c|}
\hline & Alaska & & & & & & \\
\hline 1 & Prudhoe, 1968 & Cambden & Triassic & Sandstone & 10000 & 3796.8 & 9500.0 \\
\hline 2 & Kuparuk, 1971 & Cambden & Cretaceous & Sandstone & 8000 & 109.6 & 1200.0 \\
\hline 3 & McArthur River, 1965 & Cook Inlet & Tertiary & Sandstone & 9500 & 499.0 & 570.0 \\
\hline 4 & Swanson River, 1968 & Cook Inlet & Tertiary & Sandstone & 11000 & 200.7 & 220.0 \\
\hline 5 & $\begin{array}{l}\text { Middle Ground Shoal, } \\
1963\end{array}$ & Cook Inlet & Tertiary & Sandstone & 7800 & 143.8 & 165.0 \\
\hline 6 & $\begin{array}{c}\text { Granite Point, } 1965 \\
\text { Totals }\end{array}$ & Cook Inlet & Tertiary & Sandstone & 8700 & $\begin{array}{r}97.9 \\
4847.8\end{array}$ & $\begin{array}{r}125.0 \\
11780.0\end{array}$ \\
\hline & California & & & & & & \\
\hline 1 & Wilmington, 1932 & Los Angeles & Tertiary & Sandstone & 4000 & 2151.6 & 2600.0 \\
\hline 2 & Midway Sunset, 1894 & San Joaquin & Tertiary & Sandstone & 3000 & 1652.1 & 2200.0 \\
\hline 3 & Kern River, 1899 & San Joaquin & Tertiary & Sandstone & 1000 & 1012.9 & 1990.0 \\
\hline 4 & Elk Hills, 1911 & San Joaquin & Tertiary & Sandstone & 3000 & 726.7 & 1475.0 \\
\hline 5 & Huntington Beach, 1929 & Los Angeles & Tertiary & Sandstone & 3000 & 1038.9 & 1150.0 \\
\hline 6 & Ventura, 1919 & Ventura & Tertiary & Sandstone & 8000 & 865.5 & 1000.0 \\
\hline 7 & Long Beach, 1921 & Los Angeles & Tertiary & Sandstone & 4000 & 898.8 & 950.0 \\
\hline 8 & Belridge South, 1911 & San Joaquin & Tertiary & Sandstone & 1000 & 436.0 & 800.0 \\
\hline 9 & Coalinga, 1890 & San Joaquin & Tertiary & Sandstone & 3000 & 710.8 & 790.0 \\
\hline 10 & Buena Vista, 1909 & San Joaquin & Tertiary & Sandstone & 5000 & 640.6 & 660.0 \\
\hline 11 & Santa Fe Springs, 1919 & Los Angeles & Tertiary & Sandstone & 4000 & 609.2 & 625.0 \\
\hline 12 & San Ardo, 1947 & Salinas & Tertiary & Sandstone & 2150 & 383.7 & 530.0 \\
\hline 13 & Coalinga-E. Ext, 1938 & San Joaquin & Tertiary & Sandstone & 6500 & 492.8 & 520.0 \\
\hline 14 & Kettleman North, 1928 & San Joaquin & Tertiary & Sandstone & 8000 & 455.9 & 460.0 \\
\hline 15 & $\begin{array}{c}\text { Point Arguello, } 1983 \\
\text { Totals }\end{array}$ & Santa Maria & Tertiary & Sandstone & 7800 & $\begin{array}{r}0.0 \\
12075.5\end{array}$ & $\begin{array}{r}350.0 \\
16100.0\end{array}$ \\
\hline & $\begin{array}{c}\text { Interior } \\
\text { western U.S.A. }\end{array}$ & & & & & & \\
\hline 1 & East Texas, 1930 & Gulf Coast & Cretaceous & Sandstone & 4000 & 4833.4 & 6000.0 \\
\hline 2 & Yates, 1926 & Permian & Upper Paleozoic & Carbonate & 2000 & 1014.1 & 1955.0 \\
\hline 3 & Wasson, 1937 & Permian & Upper Paleozoic & Carbonate & 6000 & 1586.2 & 1800.0 \\
\hline 4 & Panhandle, 1910 & Anadarko & Upper Paleozoic & Carbonate & 2700 & 1388.4 & 1480.0 \\
\hline 5 & Sho-vel-trum, 1914 & Ardmore & Paleozoic & $\begin{array}{l}\text { Carbonate, } \\
\text { Sandstone }\end{array}$ & 5350 & 1244.0 & 1380.0 \\
\hline 6 & Kelly-Snyder, 1948 & Permian & Upper Paleozoic & Carbonate & 4535 & 1176.1 & 1350.0 \\
\hline 7 & Slaughter, 1936 & Permian & Upper Paleozoic & Carbonate & 7000 & 944.9 & 1200.0 \\
\hline 8 & Hawkins, 1940 & Gulf Coast & Cretaceous & Sandstone & 4350 & 778.5 & 900.0 \\
\hline 9 & Tom O'Connor, 1933 & Gulf Coast & Tertiary & Sandstone & 4000 & 695.0 & 890.0 \\
\hline 10 & Goldsmith, 1935 & Permian & Upper Paleozoic & Carbonate & 4100 & 723.8 & 800.0 \\
\hline 11 & Conroe, 1931 & Gulf Coast & Tertiary & Sandstone & 3500 & 705.9 & 775.0 \\
\hline 12 & Hastings, 1934 & Gulf Coast & Tertiary & Sandstone & 4500 & 681.1 & 770.0 \\
\hline 13 & Oklahoma City, 1928 & Anadarko & Paleozoic & $\begin{array}{l}\text { Sandstone, } \\
\text { Carbonate }\end{array}$ & 3600 & 741.0 & 748.0 \\
\hline
\end{tabular}


Table 4. - continued Selected giant and major oil fields, Northeast Quadrant, Circum-Pacific region

\begin{tabular}{|c|c|c|c|c|c|c|c|}
\hline $\begin{array}{l}\text { Map } \\
\text { No. }\end{array}$ & $\begin{array}{c}\text { Field, } \\
\text { Year Discovered }\end{array}$ & Basin & Majo & Reservoir & $\begin{array}{l}\text { Depth } \\
\text { (Feet) }\end{array}$ & $\begin{array}{c}\text { Cum. Prod. } \\
\text { 12/31/84 } \\
\text { (MMB) }\end{array}$ & $\begin{array}{c}\text { Est. Ult. } \\
\text { Recovery } \\
\text { (MMB) }\end{array}$ \\
\hline 14 & Rangely, 1933 & Uinta & $\begin{array}{l}\text { Upper Paleozoic, } \\
\text { Cretaceous }\end{array}$ & Sandstone & 3850 & 691.2 & 740.0 \\
\hline 15 & Salt Creek, 1906 & Powder River & $\begin{array}{l}\text { Cretaceous, } \\
\text { Jurassic }\end{array}$ & Sandstone & 2000 & 620.5 & 700.0 \\
\hline 16 & Bay Marchand, 1949 & Gulf Coast & Tertiary & Sandstone & 2500 & 571.9 & 690.0 \\
\hline 17 & $\begin{array}{l}\text { Spraberry Trend, } \\
1951\end{array}$ & Permian & Upper Paleozoic & $\begin{array}{l}\text { Sandstone, } \\
\text { Carbonate }\end{array}$ & 7000 & 566.0 & 645.0 \\
\hline 18 & Caillou Island, 1930 & Gulf Coast & Tertiary & Sandstone & 3650 & 590.9 & 635.0 \\
\hline 19 & Webster, 1936 & Gulf Coast & Tertiary & Sandstone & 5000 & 551.2 & 600.0 \\
\hline 20 & Smackover, 1922 & Gulf Coast & $\begin{array}{l}\text { Cretaceous, } \\
\text { Jurassic }\end{array}$ & $\begin{array}{l}\text { Sandstone, } \\
\text { Carbonate }\end{array}$ & 3500 & 543.2 & 590.0 \\
\hline 21 & Burbank, 1920 & Arkoma & Upper Paleozoic & Sandstone & 3000 & 529.6 & 550.0 \\
\hline 22 & Van, 1928 & Gulf Coast & Cretaceous & Sandstone & 1000 & 506.5 & 545.0 \\
\hline 23 & McElroy, 1926 & Permian & Upper Paleozoic & Carbonate & 2850 & 433.8 & 540.0 \\
\hline 24 & $\begin{array}{l}\text { Greater Seminole, } \\
1926\end{array}$ & Anadarko & Paleozoic & $\begin{array}{l}\text { Sandstone, } \\
\text { Carbonate }\end{array}$ & 4000 & 463.2 & 538.0 \\
\hline 25 & Levelland, 1938 & Permian & Upper Paleozoic & Carbonate & 7000 & 412.9 & 535.0 \\
\hline 26 & Elk Basin, 1915 & Bighorn & Upper Paleozoic & Sandstone & 4000 & 489.7 & 530.0 \\
\hline 27 & $\begin{array}{l}\text { S. Cowden Complex, } \\
1932\end{array}$ & Permian & Upper Paleozoic & Carbonate & 4050 & 461.1 & 525.0 \\
\hline 28 & North Cowden, 1930 & Permian & Upper Paleozoic & Carbonate & 4000 & 431.7 & 515.0 \\
\hline 29 & Thompson, 1931 & Gulf Coast & Tertiary & Sandstone & 2400 & 455.5 & 508.0 \\
\hline 30 & $\begin{array}{l}\text { South Pass Blk. 24, } \\
1950\end{array}$ & Gulf Coast & Tertiary & Sandstone & 6500 & 450.5 & 505.0 \\
\hline 31 & Golden Trend, 1945 & Anadarko & Paleozoic & $\begin{array}{l}\text { Sandstone, } \\
\text { Carbonate }\end{array}$ & 6200 & 438.7 & 500.0 \\
\hline 32 & $\begin{array}{l}\text { West Delta Blk. 30, } \\
1949\end{array}$ & Gulf Coast & Tertiary & Sandstone & 2300 & 413.5 & 500.0 \\
\hline & Totals & & & & & 26134.0 & 30939.0 \\
\hline & \multicolumn{5}{|c|}{ Total Selected Fields, NE Quadrant } & 90826.0 & 136209.0 \\
\hline
\end{tabular}


Table 5. Selected giant and major gas fields, Northeast Quadrant, Circum-Pacific region

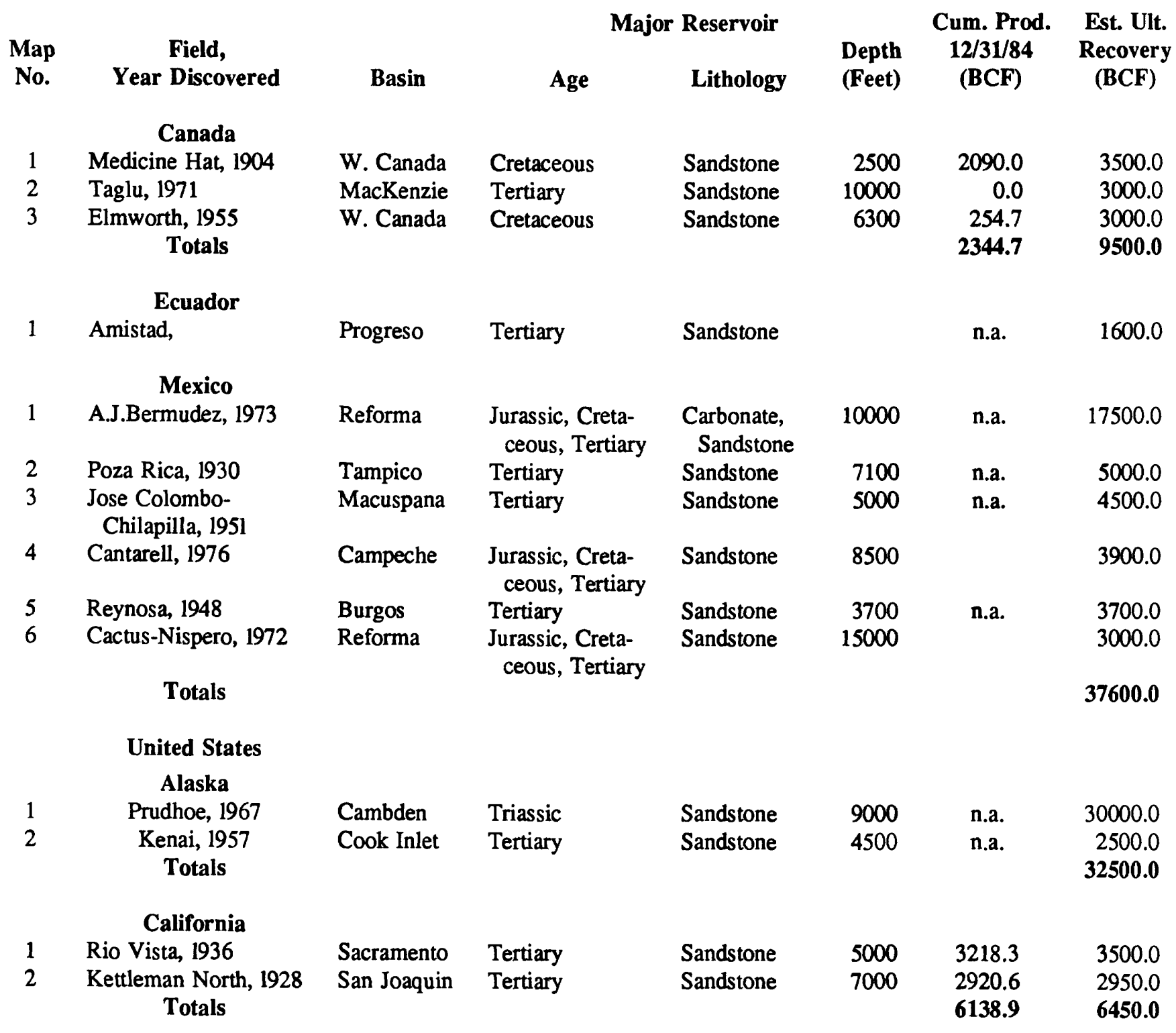


Table 5. - continued Selected giant and major gas fields, Northeast Quadrant, Circum-Pacific region

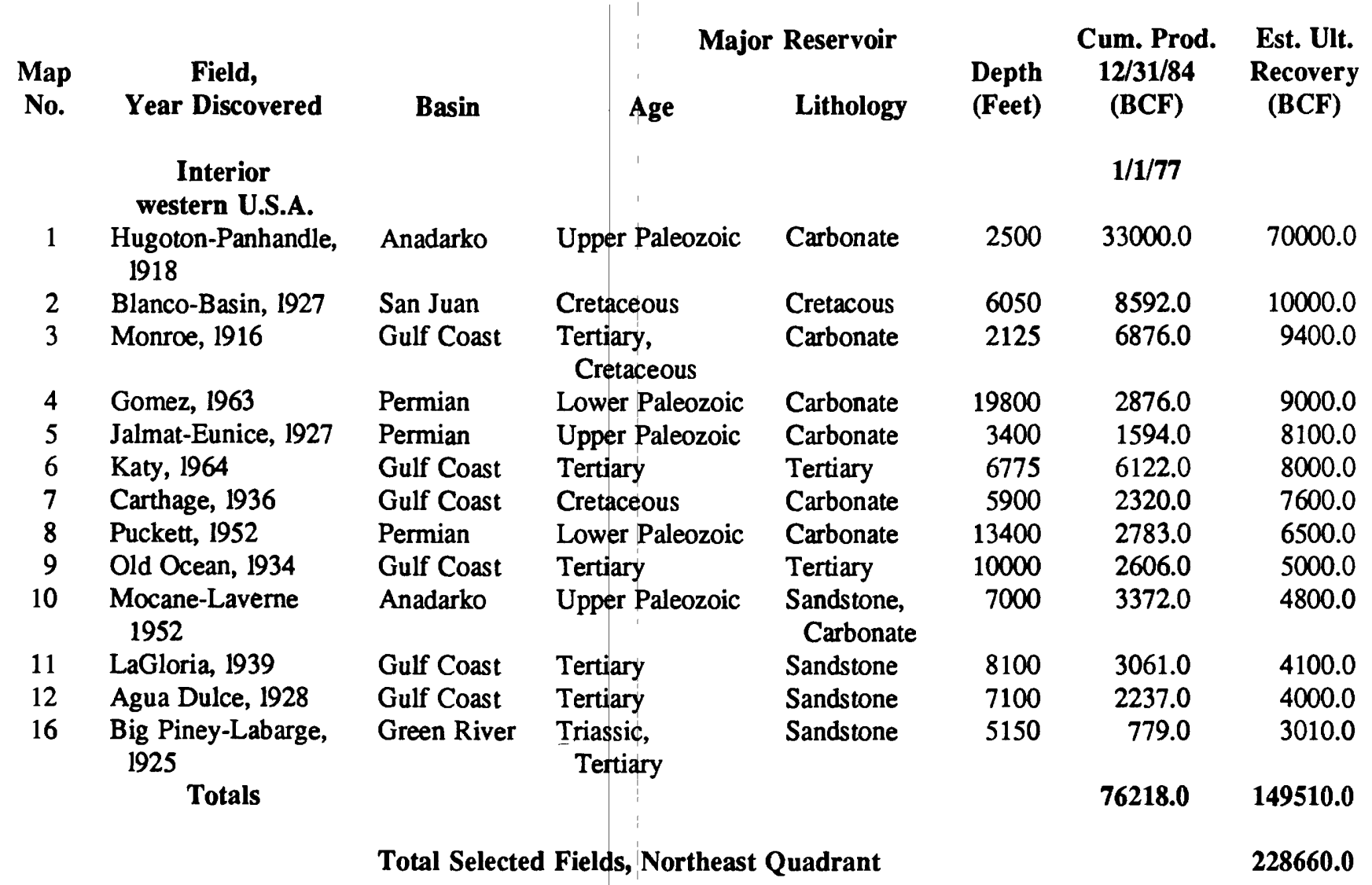


Table 6. Giant oil and gas fields with an estimated ultimate recovery of more than $500 \mathrm{MMB}$ and (or) 3 TCF, Southeast Quadrant, Circum-Pacific region

[MMB, million barrels; TCF, trillion cubic feet; -, no data. See figures 8 and 9 for location of selected basins and fields]

\begin{tabular}{|c|c|c|c|c|c|c|c|c|c|c|c|}
\hline \multirow[t]{2}{*}{ Field Name } & \multirow[t]{2}{*}{ Country } & \multirow[t]{2}{*}{ Basin } & \multirow[t]{2}{*}{$\begin{array}{c}\text { Year } \\
\text { Discovered }\end{array}$} & \multicolumn{4}{|c|}{ Major Reservoir } & \multicolumn{2}{|c|}{$\begin{array}{c}\text { Ormulative Production } \\
(12-31-87)\end{array}$} & \multicolumn{2}{|c|}{$\begin{array}{c}\text { Estimated Ultimate } \\
\text { Recovery }\end{array}$} \\
\hline & & & & Age & Lithology & $\begin{array}{c}\text { Average } \\
\text { Depth (Ft) }\end{array}$ & $\begin{array}{l}\text { Type of } \\
\text { Trap }\end{array}$ & MMB & TCF & MMB & TCF \\
\hline $\begin{array}{l}\text { South Flank } \\
\text { Group }\end{array}$ & Argentina & San Jorge & 1946 & $\begin{array}{c}\text { Jurassic/ } \\
\text { Cretaceous }\end{array}$ & Sandstone & $1600-8500$ & Fault Block & 680 & & 816 & 530 \\
\hline $\begin{array}{l}\text { North Flank } \\
\text { Group }\end{array}$ & Argentina & San Jorge & 1907 & $\begin{array}{c}\text { Cretaceous/ } \\
\text { Tertiary }\end{array}$ & Sandstone & $\begin{array}{l}2000 \\
10,500\end{array}$ & Fault Block & 568 & & 842 & 79 \\
\hline $\begin{array}{l}\text { Loma de la Lata } \\
\text { (Upper) }\end{array}$ & Argentina & Neuquen & 1977 & Cretaceous & Limestone & $5200-7200$ & $\begin{array}{l}\text { Stratigraphic } \\
\text { Structural }\end{array}$ & 30 & & 500 & \\
\hline $\begin{array}{l}\text { Loma de la Lata } \\
\text { (Lower) }\end{array}$ & Argentina & Neuquen & 1977 & Jurassic & Sandstone & $6200-8200$ & $\begin{array}{l}\text { Stratigraphic } \\
\text { Structural }\end{array}$ & & .62 & & 12 \\
\hline $\begin{array}{l}\text { Punta Bardas/ V. } \\
\text { Muerta }\end{array}$ & Argentina & Cuyo & 1961 & $\begin{array}{c}\text { Triassic/ } \\
\text { Cretaceous }\end{array}$ & Sandstone & $7200-8000$ & Anticline & 338 & & 500 & \\
\hline La Cira & Colombia & $\begin{array}{c}\text { Middle } \\
\text { Magdalena }\end{array}$ & 1925 & $\begin{array}{c}\text { Cretaceous/ } \\
\text { Tertiary }\end{array}$ & Sandstone & 3250 & Anticline & 459 & & 520 & \\
\hline Caño Limón & Colombia & Arauca & 1983 & \begin{tabular}{|c} 
Cretaceous/ \\
Tertiary
\end{tabular} & Sandstone & $7500-8200$ & Fault BIock & 108 & & 1000 & \\
\hline $\begin{array}{l}\text { Shushufindi } \\
\text { Sacha } \\
\text { Amistad }\end{array}$ & $\begin{array}{l}\text { Ecuador } \\
\text { Ecuador } \\
\text { Ecuador }\end{array}$ & $\begin{array}{c}\text { Oriente } \\
\text { Oriente } \\
\text { Progreso }\end{array}$ & $\begin{array}{l}1969 \\
1969 \\
1970\end{array}$ & $\begin{array}{c}\text { Cretaceous } \\
\text { Cretaceous } \\
\text { Tertiary? }\end{array}$ & $\begin{array}{l}\text { Sandstone } \\
\text { Sandstone } \\
\text { Sandstone }\end{array}$ & $\begin{array}{c}7500-8900 \\
7800-9300 \\
-\end{array}$ & $\begin{array}{l}\text { Anticline } \\
\text { Anticline } \\
\text { Anticline }\end{array}$ & $\begin{array}{l}495 \\
338\end{array}$ & - & $\begin{array}{c}1350 \\
743\end{array}$ & 3 \\
\hline La Brea - Parinas & Peru & Talara & 1869 & Tertiary & \begin{tabular}{|c|} 
Sandstone \\
Conglomerate
\end{tabular} & 5500 & Fault Blocks & 539 & & 592 & \\
\hline $\begin{array}{l}\text { San Martin } \\
\text { Cashiriari } \\
\end{array}$ & $\begin{array}{l}\text { Peru } \\
\text { Peru }\end{array}$ & $\begin{array}{l}\text { Ucayali } \\
\text { Ucayali }\end{array}$ & $\begin{array}{l}1984 \\
1986 \\
\end{array}$ & $\begin{array}{l}\text { Cretaceous } \\
\text { Cretaceous } \\
\end{array}$ & $\begin{array}{l}\text { Sandstone } \\
\text { Sandstone }\end{array}$ & $\begin{array}{c}12,800 \\
8800\end{array}$ & $\begin{array}{l}\text { Anticline } \\
\text { Anticline }\end{array}$ & & - & & $\begin{array}{l}3 \\
8 \\
\end{array}$ \\
\hline Fyzabad Group & Trinidad & \begin{tabular}{|l|} 
South Basin \\
\end{tabular} & 1913 & Tertiary & Sandstone & $3000-8000$ & $\begin{array}{c}\text { Stratigraphic } \\
\text { Structural }\end{array}$ & 630 & & 850 & \\
\hline Soldado & Trinidad & South Basin & 1954 & Tertiary & Sandstone & $4000-8000$ & $\begin{array}{c}\text { Stratigraphic } \\
\text { Structural }\end{array}$ & 463 & & 600 & \\
\hline East Coast & Trinidad & S.E. Coast & 1961 & Tertiary & Sandstone & $\begin{array}{l}5000- \\
11,000\end{array}$ & $\begin{array}{l}\text { Stratigraphic } \\
\text { Structural }\end{array}$ & 555 & & 700 & \\
\hline Galeota Group & Trinidad & Galeota & 1968 & Tertiary & Sandstone & $\begin{array}{l}8000- \\
14,000\end{array}$ & $\begin{array}{c}\text { Stratigraphic } \\
\text { Structural }\end{array}$ & & 5 & & 7 \\
\hline $\begin{array}{l}\text { North Coast } \\
\text { Group }\end{array}$ & Trinidad & W. Tobago & 1971 & Tertiary & Sandstone & 11,000 & $\begin{array}{c}\text { Stratigraphic } \\
\text { Structural }\end{array}$ & & NIL & & 3 \\
\hline Tia Juana & Venezuela & Maracaibo & 1928 & Tertiary & Sandstone & 3500 & $\begin{array}{c}\text { Stratigraphic } \\
\text { Fault }\end{array}$ & 10,360 & & 15,050 & \\
\hline Bachaqero & Venezuela & Maracaibo & 1930 & Tertiary & Sandstone & 3450 & $\begin{array}{c}\text { Stratigraphic } \\
\text { Fault }\end{array}$ & 6264 & & 9367 & \\
\hline Lagunillas & Venezuela & Maracaibo & 1926 & Tertiary & Sandstone & 3000 & $\begin{array}{c}\text { Stratigraphic } \\
\text { Fault }\end{array}$ & 3462 & & 5220 & \\
\hline Lama & Venezuela & Maracaibo & 1957 & $\begin{array}{c}\text { Cretaceous/ } \\
\text { Tertiary }\end{array}$ & Sandstone & 10,000 & $\begin{array}{c}\text { Stratigraphic } \\
\text { Fault }\end{array}$ & 2140 & & 2850 & \\
\hline Ceuta & Venezuela & Maracaibo & 1956 & $\begin{array}{c}\text { Cretaceous/ } \\
\text { Tertiary }\end{array}$ & Sandstone & - & $\begin{array}{c}\text { Stratigraphic } \\
\text { Fault }\end{array}$ & 505 & & 1239 & \\
\hline Cabimas & Venezuela & Maracaibo & 1917 & Tertiary & Sandstone & 2200 & $\begin{array}{c}\text { Stratigraphic } \\
\text { Fault }\end{array}$ & 489 & & 515 & \\
\hline Boscán & Venezuela & Maracaibo & 1946 & Tertiary & Sandstone & 8800 & $\begin{array}{c}\text { Anticline } \\
\text { Stratigraphic }\end{array}$ & 729 & & 2471 & \\
\hline Urdaneta & Venezuela & Maracaibo & 1956 & $\begin{array}{c}\text { Cretaceous/ } \\
\text { Tertiary }\end{array}$ & Sandstone & 10,000 & $\begin{array}{c}\text { Anticline } \\
\text { Stratigraphic }\end{array}$ & 122 & & 2058 & \\
\hline Centro & Venezuela & Maracaibo & 1957 & $\begin{array}{c}\text { Cretaceous/ } \\
\text { Tertiary }\end{array}$ & Sandstone & 10,000 & $\begin{array}{c}\text { Anticline } \\
\text { Stratigraphic }\end{array}$ & 777 & & 1702 & \\
\hline Lamar & Venezuela & Maracaibo & 1958 & $\begin{array}{c}\text { Cretaceous/ } \\
\text { Tertiary }\end{array}$ & Sandstone & 12,500 & $\begin{array}{c}\text { Anticline } \\
\text { Stratigraphic }\end{array}$ & 1095 & & 1594 & \\
\hline La Paz & Venezuela & Maracaibo & 1925 & $\begin{array}{c}\text { Cretaceous/ } \\
\text { Tertiary }\end{array}$ & Sandstone & 11,400 & $\begin{array}{c}\text { Faulted } \\
\text { Anticline }\end{array}$ & 857 & & 1042 & \\
\hline Mene Grande & Venezuela & Maracaibo & 1914 & Tertiary & Sandstone & 8000 & $\begin{array}{l}\text { Faulted } \\
\text { Anticline }\end{array}$ & 637 & & 686 & \\
\hline Santa Rosa & Venezuela & Oriental & 1941 & Tertiary & Sandstone & 10,600 & $\begin{array}{l}\text { Faulted } \\
\text { Anticline }\end{array}$ & 390 & & 697 & \\
\hline Mata & Venezuela & Oriental & 1954 & Tertiary & Sandstone & 9500 & $\begin{array}{c}\text { Faulted } \\
\text { Monocline }\end{array}$ & 469 & & 648 & \\
\hline Guara & Venezuela & Oriental & 1946 & Tertiary & Sandstone & 7800 & $\begin{array}{c}\text { Faulted } \\
\text { Monocline }\end{array}$ & 424 & & 606 & \\
\hline Oficina & Venezuela & Oriental & 1917 & Tertiary & Sandstone & 6900 & Fault Block & 384 & & 525 & \\
\hline Cerro Negro & Venezuela & Orinoco & 1979 & Tertiary & Sandstone & - & Stratigraphic & 20.3 & & 11,183 & \\
\hline San Diego & Venezuela & Orinoco & - & - & - & - & 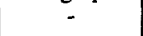 & - & & 4557 & \\
\hline Iguana & Venezuela & Orinoco & - & - & - & - & - & - & & 4176 & \\
\hline Jobo & Venezuela & Orinoco & 1956 & - & - & - & - & 267 & & 1453 & \\
\hline Morichal & Venezuela & Orinoco & 1958 & - & - & 3300 & - & 169 & & 946 & \\
\hline Santa Clara & Venezuela & Orinoco & - & - & - & - & - & - & & 913 & \\
\hline Quiriquire & Venezuela & Oriental & 1928 & $\begin{array}{c}\text { Cretaceous/ } \\
\text { Tertiary }\end{array}$ & Sandstone & 7000 & Stratigraphic & 760 & & 885 & \\
\hline Uverito & Venezuela & Orinoco & 1981 & Tertiary & Sandstone & - & - & 1 & & 854 & \\
\hline Bare & Venezuela & Orinoco & - & - & Sandstone & - & - & 7.5 & & 763 & \\
\hline Sur & Venezuela & Orinoco & - & $\begin{array}{c}\text { Cretaceous/ } \\
\text { Tertiary }\end{array}$ & Sandstone & 14,000 & Stratigraphic & - & & 602 & \\
\hline Melones & Venezuela & Orinoco & 1934 & Tertiary & Sandstone & 5200 & Faulted & 114 & & 600 & \\
\hline Arecuna & Venezuela & Orinoco & - & - & Sandstone & - & $\begin{array}{c}- \\
-\end{array}$ & - & & 567 & \\
\hline $\begin{array}{l}\text { El Furrial } \\
\text { El Placer }\end{array}$ & Venezuela & Oriental & 1985 & Tertiary & Sandstone & - & Fault Block & 8 & & 529 & \\
\hline El Placer & Venezuela & Oriental & 1984 & Tertiary & Sandstone & - & Stratigraphic & & .25 & & 4.5 \\
\hline
\end{tabular}


Table 7. Major oil and gas fields with an estimated ultimate recovery of more than $100 \mathrm{MMB}$ and (or) $600 \mathrm{BCF}$, Southeast Quadrant, Circum-Pacific region

[MMB, million barrels; TCF, trillion cubic feet; n.a., data not available; ---, no data. See figures 10 and 11 for location of selected basins and fields]

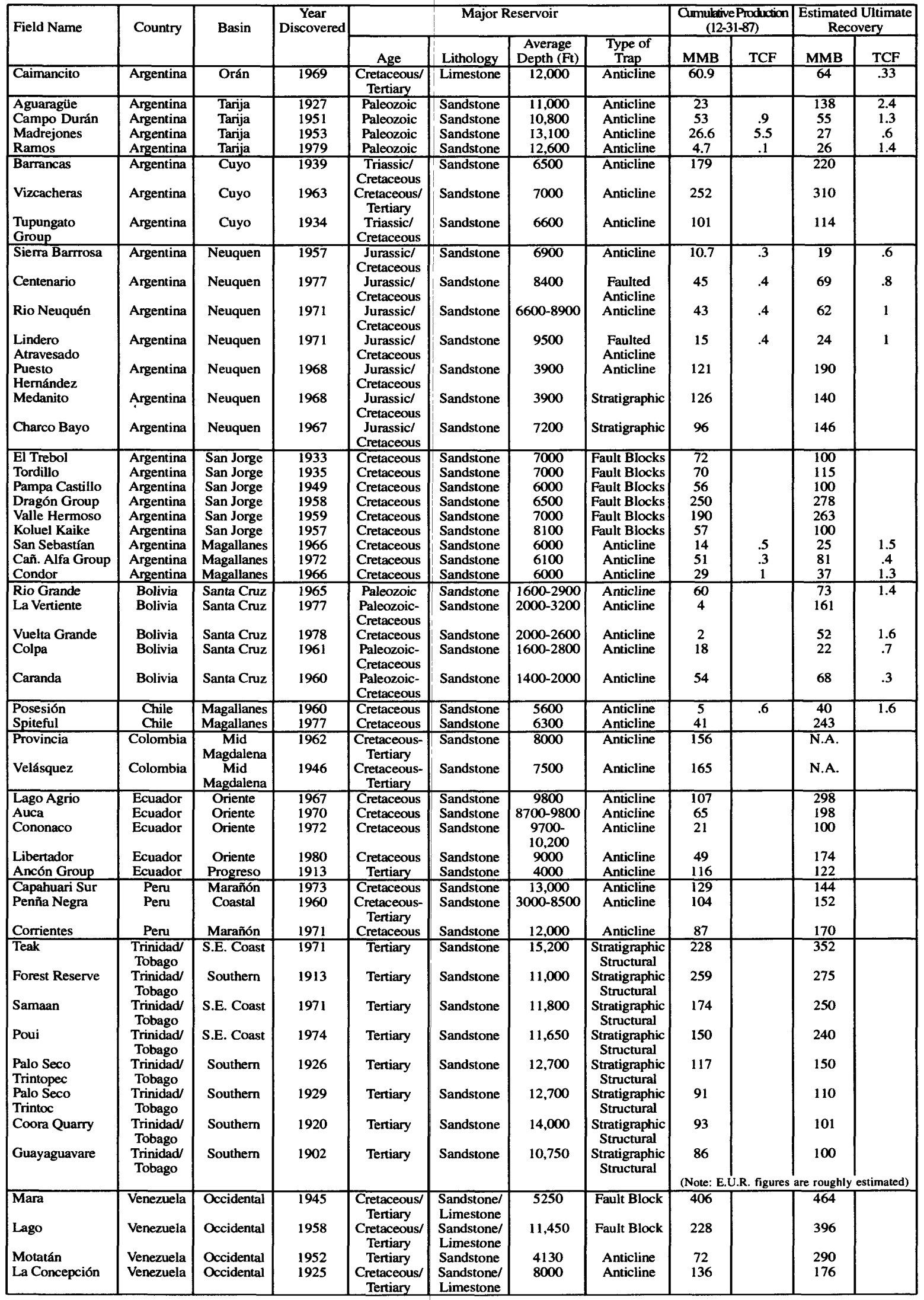


Table 7.-continued Major oil and gas fields with an estimated ultimate recovery of more than $100 \mathrm{MMB}$ and (or) $600 \mathrm{BCF}$, Southeast Quadrant, Circum-Pacific region

[MMB, million barrels; TCF, trillion cubic feet; n.a., data not available; ---, no data. See figures 10 and 11 for location of selected basins and fields]

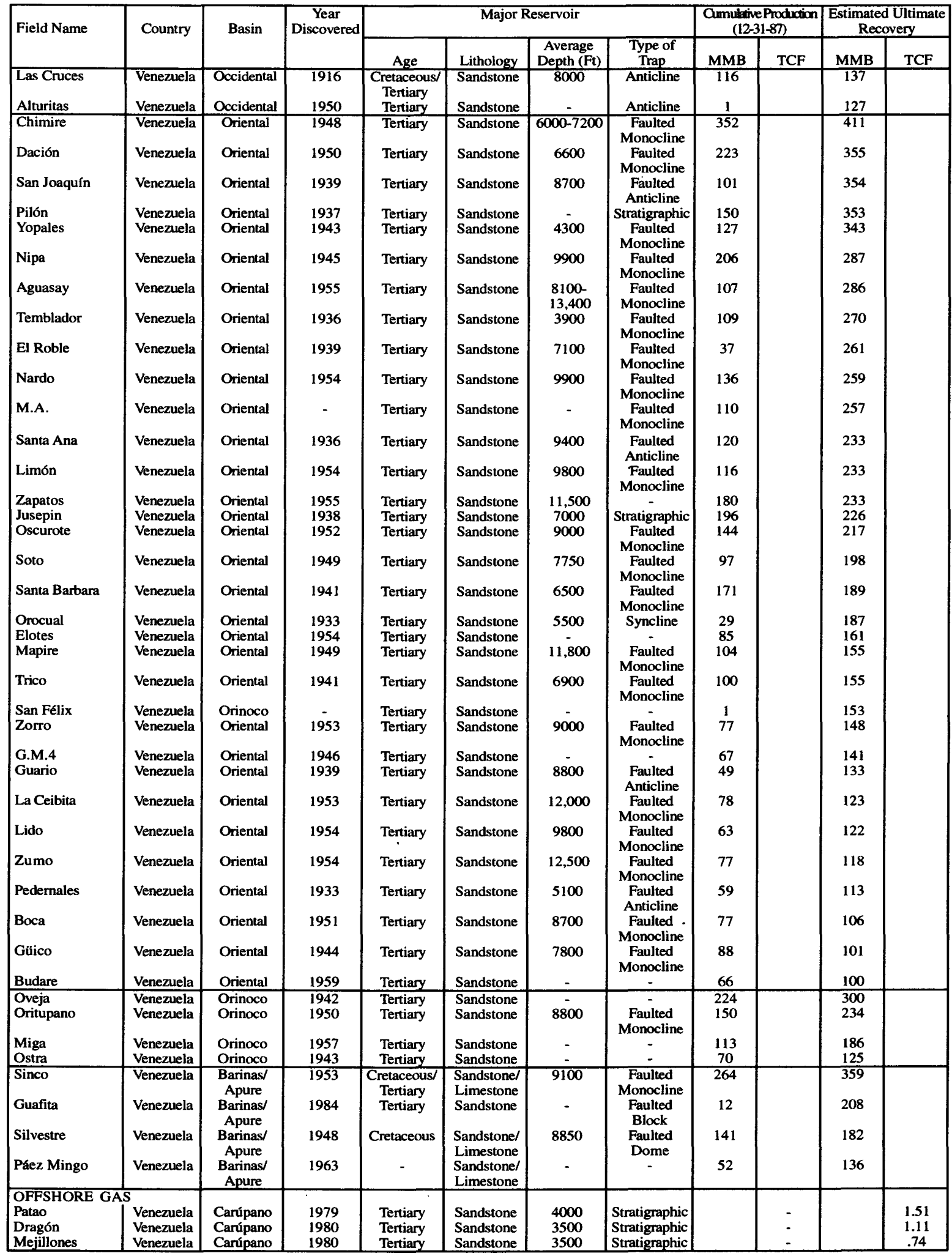


Table 8. List of sedimentary basins, Northwest Quadrant, Circum-Pacific region (numbers refer to figure 12)

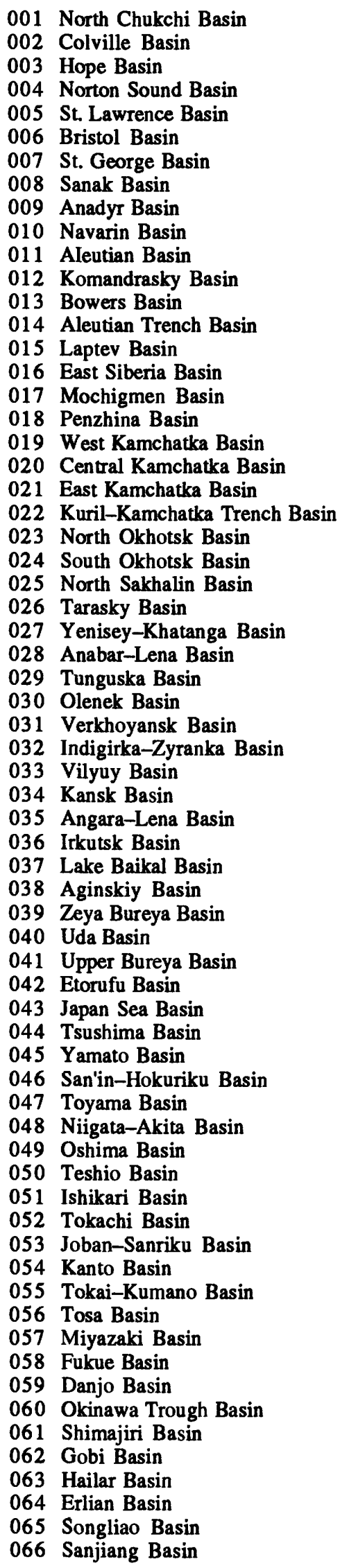

067 Jiuquan-Minle Basin

068 Chaidamu Basin

069 Minghe Basin

070 North Tibet Basin

071 Heime Basin

072 Chagpu Basin

073 Himalaya Basin

074 Eerdosi (Ordos) Basin

075 Fenhe Basin

076 Huabei Basin

077 Bohai Basin

078 Korea Bay Basin

079 Yellow Sea Basin

080 Shanghai Basin

081 East China Sea Basin

082 Nanxiang Basin

083 Jianghan Basin

084 Yuanma Basin

085 Shichuan Basin

086 Chuxiong Basin

087 Lamping-Simao Basin

088 Baise Basin

089 Shiwandashan Basin

090 West Taiwan Basin

091 Beibu Gulf Basin

092 Tonkin Basin

093 Pearl River Mouth Basin

094 South China Sea Basin

095 Ganges Basin

096 Assam Basin

097 Bengal Basin

098 North Myanmar (Burma) Basin

099 South Myanmar (Burma) Basin

100 Irrawaddy Delta Basin

101 Gulf of Martaban Basin

102 Andaman Basin

103 Nicobar Basin

104 Andaman Sea Basin

105 Nicobar Trench Basin

106 Nicobar Fan Basin

107 Fang Basin

108 Chao-Phraya Basin

109 Khorat Basin

110 Bangkok Basin

111 Thai Basin

112 Mekong Basin

113 Saigon Basin

114 Spratly Basin

115 Cagayan Basin

116 Lingayen Basin

117 Ilocos Basin

118 Zambales Basin

119 Southern Luzon Basin

120 Mindoro Basin

121 Iloilo Basin

122 Reed Bank Basin

123 West Palawan Basin

124 Balabac Basin

125 Sulu Basin

126 Visayan Sea Basin

127 Cotabato Basin

128 Agusan-Davao Basin

129 Malay Basin

130 Penyu Basin

131 Sokang Basin

132 Sarawak Basin
133 Brunei-Sabah Basin

134 North Sumatra Basin

135 Sibolga Basin

136 Central Sumatra Basin

137 South Sumatra Basin

138 Bengkulu Basin

139 Sunda Basin

140 Northwest Java Basin

141 South Java Basin

142 Pati Basin

143 Northeast Java Basin

144 Lombom Bali Basin

145 Flores Basin

146 Sawu Basin

147 Tukangbesi Basin

148 Timor Basin

149 Ketungau Basin

150 Melawi Basin

151 Tarakan Basin

152 Kutei Basin

153 Minasa Basin

154 Belitung Basin

155 Pembuang Basin

156 Barito Basin

157 Asem-Asem Basin

158 Gorontalo Basin

159 Larian Basin

160 Makasar Basin

161 Spermonde Basin

162 Bone Basin

163 Banggai Basin

164 Manhui Basin

165 Buton Basin

166 Sula Basin

167 South Sula Basin

168 Buru Basin

169 North Obi Basin

170 South Obi Basin

171 North Halmahera Basin

172 East Halmahera Basin

173 South Halmahera Basin

174 Salawati Basin

175 Bintuni Basin

176 Misool Basin

177 Seram Basin

178 South Seram Basin

179 West Weber Basin

180 Weber Basin

181 Tanimbar Basin

182 Palungaru Basin

183 Waropen Basin

184 Biak Basin

185 Waipoga Basin

186 Akimegah Basin

187 Sahul Basin

188 Wewak Basin

189 Sepik Basin

190 Ramu Basin

191 Madan Basin

192 Morehead Basin

193 Papuan Basin

194 Cape Vogel Basin

195 New Ireland Basin

196 Bougainville Basin

197 Solomon Basin 
Table 9. General characteristics of selected oil and gas fields, Northwest Quadrant, Circum-Pacific region (refer to figures 13 and 14)

[Basin number refers to figure 13; field number refers to figure 14; $\mathrm{O}=\mathrm{Oil}, \mathrm{G}=\mathrm{Gas}, \mathrm{O} / \mathrm{G}=\mathrm{Oil}$ and $\mathrm{Gas} ;-$, data not available]

\begin{tabular}{|c|c|c|c|c|c|c|}
\hline $\begin{array}{l}\text { Basin number } \\
\text { Field number }\end{array}$ & $\begin{array}{l}\text { Type } \\
\text { Field }\end{array}$ & Basin-Field name & $\begin{array}{c}\text { Year } \\
\text { discovered }\end{array}$ & Reservoir age & Lithology & $\begin{array}{l}\text { Cumulative } \\
\text { production } 1\end{array}$ \\
\hline 009 & & Anadyr Basin & & & & \\
\hline 1 & $\mathbf{G}$ & Anadyr & - & - & - & - \\
\hline 025 & & North Sakhalin Basin & & & & \\
\hline 1 & $\mathbf{O}$ & Kolenda & 1963 & Miocene-Pliocene & Sandstone & - \\
\hline 2 & $\mathbf{O}$ & Giljako & 1949 & Miocene-Pliocene & Sandstone & - \\
\hline 3 & $\mathbf{G}$ & Nizhnie Dagi & - & Miocene-Pliocene & Sandstone & - \\
\hline 4 & $\mathbf{O}$ & Nekrasovka & 1967 & Miocene-Pliocene & Sandstone & - \\
\hline 5 & $\mathbf{O}$ & Odoptu & 1965 & Miocene-Pliocene & Sandstone & - \\
\hline 6 & $\mathbf{O}$ & Sabo & - & Miocene-Pliocene & Sandstone & - \\
\hline 7 & 0 & Mukhta & 1959 & Miocene-Pliocene & Sandstone & - \\
\hline 8 & $\mathbf{O}$ & Paromai & 1929 & Miocene-Pliocene & Sandstone & - \\
\hline 9 & 0 & Katangli & 1929 & Miocene-Pliocene & Sandstone & - \\
\hline 10 & 0 & Pogranichnoye & - & Miocene-Pliocene & Sandstone & - \\
\hline 026 & & Tarasky Basin & & & & \\
\hline 1 & $\mathbf{O}$ & Nevelsk & - & - & - & - \\
\hline 2 & $\mathbf{G}$ & Aniva & - & - & - & - \\
\hline $\mathbf{0 3 3}$ & & Vilyuy Basin & & & & \\
\hline 1 & $\mathbf{G}$ & Sredne-Tyungskoye & 1976 & Triassic-Jurassic & Sandstone & - \\
\hline$\dagger 2$ & $G$ & Sredne-Vilyuiskoye & 1963 & Triassic-Jurassic & Sandstone & - \\
\hline 3 & $G$ & $\begin{array}{l}\text { Tolon-Mastakhskoye } \\
\text { (Maastakh) }\end{array}$ & 1967 & Triassic-Jurassic & Sandstone & - \\
\hline 4 & $\mathbf{G}$ & Sobolokh-Nedzhelinskoye & - & Triassic-Jurassic & Sandstone & - \\
\hline 5 & $\mathbf{G}$ & Badaranskoye & 1963 & Triassic-Jurassic & Sandstone & - \\
\hline 6 & $\mathbf{G}$ & Nizhne-Vilyuiskoye & - & Triassic-Jurassic & Sandstone & - \\
\hline 7 & $\mathbf{G}$ & Ust-Vilyuskoye & 1956 & Triassic-Jurassic & Sandstone & - \\
\hline 8 & $O / G$ & Irelyakhshoye & 1961 & Triassic-Jurassic & Sandstone & - \\
\hline 9 & $O / G$ & Machchobinskoye & - & Triassic-Jurassic & Sandstone & - \\
\hline 10 & $O / G$ & Sredne-Botuobinskoye & 1970 & Precambrian-Cambrian & Sandstone-carbonate & - \\
\hline 11 & $\mathrm{O} / \mathrm{G}$ & Tas-Yurakhskoye & 1981 & Triassic-Jurassic & Sandstone & - \\
\hline 12 & $\mathbf{G}$ & Iktekhskoye & - & Triassic-Jurassic & Sandstone & - \\
\hline 13 & $O / G$ & Verhne-Vilyuchanskoye & 1975 & Triassic-Jurassic & Sandstone & - \\
\hline 14 & O/G & Vilyuisko-Dzherbinskoye & 1977 & Triassic-Jurassic & Sandstone & - \\
\hline 15 & $\mathrm{O} / \mathrm{G}$ & Verkhne-Chopskoye & - & Triassic-Jurassic & Sandstone & - \\
\hline 16 & $\mathbf{G}$ & Ozernoye & 1963 & Triassic-Jurassic & Sandstone & - \\
\hline 17 & $\mathbf{G}$ & Nizhne-Khamakinskoye & - & Triassic-Jurassic & Sandstone & - \\
\hline 18 & $\mathbf{G}$ & Talakanskoye & - & Triassic-Jurassic & Sandstone & - \\
\hline 035 & & Angara-Lena Basin & & & & \\
\hline 1 & $\mathrm{O} / \mathrm{G}$ & Danilovskoye & - & Proterozoic-Cambrian & Sandstone-carbonate & - \\
\hline 2 & $\mathrm{O} / \mathrm{G}$ & Dilisminskoye & - & Proterozoic-Cambrian & Sandstone-carbonate & - \\
\hline 3 & 0 & Yarakinskoye & 1971 & Proterozoic & Sandstone & - \\
\hline 4 & O/G & Ayanskoye & - & Proterozoic-Cambrian & Sandstone-carbonate & - \\
\hline 5 & O/G & Markovo & 1962 & Proterozoic-Cambrian & Sandstone-carbonate & - \\
\hline 6 & 0 & Pilyudinskoye & - & Proterozoic-Cambrian & Sandstone-carbonate & - \\
\hline 036 & & Irkutsk Basin & & & & \\
\hline 1 & $\mathbf{G}$ & Atovskoye & - & Proterozoic-Cambrian & Sandstone-carbonate & - \\
\hline 2 & $\mathbf{G}$ & Bilchirskoye & - & Proterozoic-Cambrian & Sandstone-carbonate & - \\
\hline 3 & $\mathbf{G}$ & Yuzhno-Raduiskoye & - & Cambrian & Carbonate & - \\
\hline 4 & G & Khristoforovskoye & 1968 & Cambrian & Carbonate & - \\
\hline 5 & G & Balukhtinsko-Tuptinskoye & - & Proterozoic-Cambrian & Sandstone-carbonate & - \\
\hline
\end{tabular}


Table 9.-continued General characteristics of selected oil and gas fields, Northwest Quadrant, Circum-Pacific region (refer to figures 13 and 14)

[Basin number refers to figure 13; field number refers to figure 14; $O=O$ Oil, $G=G a s, O / G=O i l$ and $G a s ;-$, data not available]

\begin{tabular}{|c|c|c|c|c|c|c|}
\hline $\begin{array}{l}\text { Basin number } \\
\text { Field number }\end{array}$ & $\begin{array}{l}\text { Type } \\
\text { Field } \\
\end{array}$ & Basin-Field name & $\begin{array}{c}\text { Year } \\
\text { discovered }\end{array}$ & Reservoir age & Lithology & $\begin{array}{l}\text { Cumulative } \\
\text { production } 1\end{array}$ \\
\hline 048 & & Niigata-Akita Basin & & & & \\
\hline 1 & $\mathbf{O}$ & Yabase & 1933 & Miocene-Pliocene & Sandstone & $33,216,000$ \\
\hline 2 & $\mathbf{G}$ & Aga-oki & 1972 & Miocene-Pliocene & Sandstone & $6,069,000$ \\
\hline 3 & $O K G$ & Niitu-Minami Aga & 1899 & Miocene-Pliocene & Sandstone & 13,824 \\
\hline 4 & $\mathbf{O K G}$ & Higashi Niigata-Matsuzaki & 1959 & Miocene-Pliocene & Sandstone & $9,871,000$ \\
\hline 5 & $\mathbf{G}$ & Nakajo-Shin Tainai & 1961 & Miocene-Pliocene & Sandstone & $6,924,000$ \\
\hline 6 & $\mathbf{G}$ & Yoshii-Higashi Kashiwazaki & 1968 & Miocene & Volcanics & $16,982,000$ \\
\hline 7 & OKG & Kubiki & 1959 & Miocene-Pliocene & Sandstone & $13,162,000$ \\
\hline 053 & & Joban-Sanriku Basin & & & & \\
\hline 1 & $\mathbf{G}$ & Iwaki & 1973 & Miocene & Sandstone & 167,000 \\
\hline 065 & & Songliao Basin & 1 & & & \\
\hline 1 & $O$ & Daqing & 1959 & Cretaceous & Sandstone & $7,094,000,000$ \\
\hline 2 & $\mathbf{O}$ & Tengluku & 1958 & Cretaceous & Sandstone & - \\
\hline 3 & $\mathbf{0}$ & Kongchuling & 1958 & Cretaceous & Sandstone & - \\
\hline $\begin{array}{c}4 \\
067\end{array}$ & $\mathbf{O}$ & $\begin{array}{l}\text { Chinshankou } \\
\text { Jiuquan-Minle Basin }\end{array}$ & 1958 & Cretaceous & Sandstone & - \\
\hline 1 & o & Yaerhxia & - & $\begin{array}{c}\text { Miocene, Cretaceous, } \\
\text { Silurian }\end{array}$ & Sandstone & - \\
\hline 2 & 0 & Laojumiao & 1938 & Miocene & Sandstone & - \\
\hline 3 & $\mathbf{0}$ & Shiyougou & 1928 & Miocene & Sandstone & - \\
\hline 074 & & Eerdosi (Ordos) Basin & & & & \\
\hline 1 & $\mathbf{0}$ & Chingtuching & - & - & - & - \\
\hline 2 & $\mathbf{0}$ & Machiatan & 1951 & Triassic-Jurassic & Sandstone-carbonate & - \\
\hline 3 & $\mathbf{0}$ & Shatingtzu & 1950 & Triassic-Cretaceous & Sandstone-carbonate & - \\
\hline 4 & 0 & Yungping & 1930 & Triassic & Sandstone & - \\
\hline 5 & $\mathbf{0}$ & Tsaoyuan & 1952 & Triassic & Sandstone & - \\
\hline 6 & $\mathbf{0}$ & Yenchang & 1957 & Jurassic & Sandstone & - \\
\hline 076 & & Huabei Basin & & & & \\
\hline 1 & 0 & Renqiu & 1975 & Precambrian-Ordovician & Carbonate & 970,380 \\
\hline 2 & 0 & Dagang & 1964 & Cenozoic & Sandstone-carbonate & $408,000,000$ \\
\hline 3 & $\mathbf{O}$ & Lin-i & 1976 & Precambrian & Carbonate & - \\
\hline 4 & $\mathbf{0}$ & Sha-yen & - & - & - & - \\
\hline 5 & $\mathbf{O}$ & Qianjiang & 1966 & - & - & 192,590 \\
\hline 6 & $O$ & Zhongyuan & 1975 & Paleogene & Sandstone & - \\
\hline 7 & $\mathbf{G}$ & Guxinzhuang & -1 & - & - & - \\
\hline 077 & & Bohai Basin & & & & \\
\hline 1 & $\mathbf{O}$ & Shengli & 1962 & Paleogene & Sandstone & $2,623,000$ \\
\hline 2 & 0 & Gudao & 1968 & Miocene & Sandstone & - \\
\hline 3 & 0 & Chengbei & 1972 & - & - & $11,000,000$ \\
\hline 4 & $\mathbf{0}$ & Haishi & 1970 & - & - & $10,000,000$ \\
\hline 081 & & East China Sea Basin & & & & \\
\hline 1 & $\mathbf{G}$ & Longjing & 1981 & - & - & - \\
\hline 2 & $\mathbf{G}$ & Chingtzaohu & 1967 & Miocene & Sandstone & - \\
\hline 3 & $\mathbf{G}$ & Tiehchenshan & 1959 & Miocene & Sandstone & $105,000,000$ \\
\hline 4 & $\mathbf{G}$ & Chinshui-Yunghoshan & 1971 & Oligocene-Miocene & Sandstone & - \\
\hline 5 & $\mathbf{G}$ & Chuhuangkeng & 1904 & Oligocene-Miocene & Sandstone & $3,000,000$ \\
\hline 083 & & Jianghan Basin & & & & \\
\hline 1 & 0 & Wangchang & 1965 & Paleogene & Sandstone & - \\
\hline 2 & 0 & Zhongshi & 1965 & Paleogene & Sandstone & - \\
\hline 3 & O & Xijakou & - & Paleogene & Sandstone & - \\
\hline 4 & $\mathbf{O}$ & Huayuan & - & Paleogene & Sandstone & - \\
\hline
\end{tabular}


Table 9.-continued General characteristics of selected oil and gas fields, Northwest Quadrant, Circum-Pacific region (refer to figures 13 and 14)

[Basin number refers to figure 13; field number refers to figure $14 ; \mathrm{O}=\mathrm{Oil}, \mathrm{G}=\mathrm{Gas}, \mathrm{O} / \mathrm{G}=\mathrm{Oil}$ and $\mathrm{Gas} ;-$, data not available]

\begin{tabular}{|c|c|c|c|c|c|c|}
\hline $\begin{array}{l}\text { Basin number } \\
\text { Field number }\end{array}$ & $\begin{array}{l}\text { Type } \\
\text { Field } \\
\end{array}$ & Basin-Field name & $\begin{array}{c}\text { Year } \\
\text { discovered }\end{array}$ & Reservoir age & Lithology & $\begin{array}{l}\text { Cumulative } \\
\text { production } 1 \\
\end{array}$ \\
\hline $\begin{array}{c}5 \\
085\end{array}$ & 0 & $\begin{array}{l}\text { Xingou } \\
\text { Shichuan Basin }\end{array}$ & - & Paleogene & Sandstone & - \\
\hline 1 & $o$ & Lungnussu & 1956 & Jurassic & Sandstone & - \\
\hline 2 & o & Loutuhsi & 1956 & Jurassic & Sandstone & - \\
\hline 3 & o & Penglaichen & 1954 & Jurassic & Sandstone & - \\
\hline 4 & G & Chiliuing & 200 B.C. & Triassic & Carbonate & - \\
\hline 5 & G & Shengdengshan & 1938 & Triassic & Carbonate & - \\
\hline 6 & G & Yenkaoxi & 1955 & Permian & Carbonate & - \\
\hline 7 & G & Chanyuanpa & 1955 & Permian-Triassic & Carbonate & - \\
\hline 8 & G & Nashi & 1955 & Permian-Triassic & Carbonate & - \\
\hline 9 & $O / G$ & Shiyoukou-Tungchi & 1955 & Triassic & Carbonate & - \\
\hline 10 & O/G & Huangkuanshan & 1955 & Triassic & Carbonate & - \\
\hline 088 & & Baise Basin & & & & \\
\hline 1 & o & Lunxu & - & Eocene & Sandstone & - \\
\hline 2 & 0 & Xinzhou & 1961 & Eocene & Sandstone & - \\
\hline 3 & 0 & Naman & 1961 & Eocene & Sandstone & - \\
\hline 4 & 0 & Linpeng & 1961 & Eocene & Sandstone & - \\
\hline 091 & & Beibu Gulf Basin & & & & \\
\hline 1 & $\mathbf{o}$ & Wan & 1977 & - & - & - \\
\hline 2 & o & Wushi & 1981 & - & - & - \\
\hline 092 & & Tonkin Basin & & & & \\
\hline 1 & G & Wenchang & 1984 & - & - & - \\
\hline 2 & G & Yacheng & 1983 & - & - & - \\
\hline 093 & & Pearl River Mouth Basin & & & & \\
\hline 1 & $\mathbf{o}$ & Xijiong & 1985 & Oligocene-Miocene & Sandstone-carbonate & - \\
\hline 2 & 0 & Huizhou & 1985 & Oligocene-Miocene & Sandstone-carbonate & - \\
\hline 3 & 0 & Zhu 5 & 1979 & - & - & - \\
\hline 096 & & Assam Basin & & & & \\
\hline 1 & 0 & Nahorkatiya-Hugrijan & 1953 & Oligocene-Miocene & Sandstone & 303,880 \\
\hline 2 & 0 & Digboi & 1980 & Miocene & Sandstone & 74,250 \\
\hline 3 & 0 & Makum & - & - & - & - \\
\hline 4 & $O / G$ & Moran & 1956 & Oligocene-Miocene & Sandstone & 93,900 \\
\hline 5 & 0 & Rudrasagar & 1960 & - & - & $33,806,000$ \\
\hline 097 & & Bengal Basin & & & & \\
\hline 1 & G & Badarpur & - & Oligocene & Sandstone & - \\
\hline 2 & G & Chhatak & 1959 & Miocene-Pliocene & Sandstone & - \\
\hline 3 & $\mathbf{G}$ & Sylhet & 1955 & Miocene & Sandstone & - \\
\hline 4 & $\mathbf{G}$ & Kailas Tila & 1961 & Miocene & Sandstone & - \\
\hline 5 & G & Rashidpur & 1960 & Miocene & Sandstone & - \\
\hline 6 & G & Habiganj & 1963 & Miocene & Sandstone & - \\
\hline 7 & G & Titas & 1962 & Miocene & Sandstone & - \\
\hline 8 & G & Bakhrabad & 1968 & Miocene & Sandstone & - \\
\hline 9 & G & Kutubdia & 1974 & Miocene-Pliocene & Siltstone & - \\
\hline $\begin{array}{c}10 \\
099\end{array}$ & $O / G$ & $\begin{array}{l}\text { Feni } \\
\text { South Myanmar (Burma) } \\
\qquad \text { Basin }\end{array}$ & 1980 & Pliocene & Sandstone & - \\
\hline 1 & 0 & Indaw & 1918 & Miocene & Sandstone & $1,000,000$ \\
\hline 2 & 0 & Lanywa & 1927 & - & - & \\
\hline 3 & o & Chauk & 1902 & Oligocene & Sandstone & $128,000,000$ \\
\hline 4 & 0 & Mann & 1960 & - & - & $19,000,000$ \\
\hline
\end{tabular}


Table 9.-continued General characteristics of selected oil and gas fields, Northwest Quadrant, Circum-Pacific region (refer to figures 13 and 14)

[Basin number refers to figure 13: field number refers to figure 14; $O=O \mathrm{Oil}, \mathrm{G}=\mathrm{Gas}, \mathrm{O} / \mathrm{G}=\mathrm{Oil}$ and $\mathrm{Gas} ;-$, data not available]

\begin{tabular}{|c|c|c|c|c|c|c|}
\hline $\begin{array}{l}\text { Basin number } \\
\text { Field number }\end{array}$ & $\begin{array}{l}\text { Type } \\
\text { Field }\end{array}$ & Basin-Field name & $\begin{array}{c}\text { Year } \\
\text { discovered }\end{array}$ & Reservoir age & Lithology & $\begin{array}{l}\text { Cumulative } \\
\text { production } 1\end{array}$ \\
\hline 5 & $\mathbf{0}$ & Yenangyaung & 1800 & Oligocene-Miocene & Sandstone & $192,000,000$ \\
\hline 6 & 0 & Minbu & $1910^{\prime}$ & Miocene & Sandstone & - \\
\hline $\begin{array}{c}7 \\
100\end{array}$ & $\mathbf{0}$ & $\begin{array}{l}\text { Htaukshabin } \\
\text { Irrawaddy Delta Basin }\end{array}$ & 1960 & - & - & $88,000,000$ \\
\hline 1 & $\mathbf{0}$ & Prome & 1965 & Miocene & Sandstone & $7,000,000$ \\
\hline 2 & $\mathbf{0}$ & Myanaung & 1964 & Miocene & Sandstone & $21,000,000$ \\
\hline 3 & $\mathbf{0}$ & Shwepyitha & 1966 & - & - & - \\
\hline 4 & $\mathbf{G}$ & Payagon & - & Miocene & Sandstone & - \\
\hline 107 & & Fang Basin & & & & \\
\hline 1 & $\mathbf{0}$ & Mae Fang & 1953 & Miocene-Pliocene & Sandstone & - \\
\hline 2 & 0 & Mae Suhn & 1963 & Miocene-Pliocene & Sandstone & $3,000,000$ \\
\hline 108 & & Chao-Phraya Basin & & & & \\
\hline 1 & 0 & Sirikit & 1981 & - & - & $34,100,000$ \\
\hline 2 & 0 & Pru Krathiam & 1984 & - & - & 17,000 \\
\hline 110 & & Bangkok Basin & & & & - \\
\hline 1 & G & Bung Ya & 1984 & Oligocene-Miocene & Sandstone & - \\
\hline 2 & $\mathbf{G}$ & Platong & 1976 & Oligocene-Miocene & Sandstone & $5,523,200$ \\
\hline 111 & & Thai Basin & & & & \\
\hline 1 & G & Trat & 1981 & - & - & - \\
\hline 2 & G & Pakarang & 1982 & - & - & - \\
\hline 3 & $O / G$ & Satun & 1980 & Pliocene & Sandstone & $6,010,500$ \\
\hline 4 & G & Erawan & 1973 & - & - & $16,736,700$ \\
\hline 5 & G & Jakrawan & 1976 & - & - & - \\
\hline 6 & G & Baanpot & 1974 & - & - & $2,018,300$ \\
\hline 7 & G & Funan & 1981 & - & - & - \\
\hline 123 & & West Palawan Basin & & & & \\
\hline 1 & 0 & Nido & 1977 & Oligocene-Miocene & Carbonate & $15,797,886$ \\
\hline 2 & 0 & Matinloc & 1978 & Miocene & Carbonate & $9,448,230$ \\
\hline 3 & 0 & Cadlao & 1977 & Miocene & Carbonate & $9,919,265$ \\
\hline 4 & 0 & Pandan & 1980 & - & - & - \\
\hline 5 & $\mathbf{0}$ & Libro & 1980 & - & - & - \\
\hline 6 & 0 & Galoc & 1981 & Miocene & Sandstone & 383,460 \\
\hline 7 & $\mathbf{0}$ & Tara & 1987 & - & - & 145,885 \\
\hline 129 & & Malay Basin & & & & \\
\hline 1 & G & Pilong & 1971 & Oligocene-Miocene & Sandstone & - \\
\hline 2 & G & Tekok-Telok Barat & 1979 & - & - & - \\
\hline 3 & 0 & Guntong & 1978 & - & Sandstone & $17,000,000$ \\
\hline 4 & o & Tabu & 1978 & - & Sandstone & $7,000,000$ \\
\hline 5 & 0 & Tapis & 1975 & Miocene & Sandstone & $201,000,000$ \\
\hline 6 & $\mathbf{0}$ & Kepong Tinggi & 1979 & Miocene & Sandstone & $72,000,000$ \\
\hline 7 & 0 & Tiong & 1978 & Miocene & Sandstone & $102,000,000$ \\
\hline 8 & 0 & Pulai & 1973 & Miocene & Sandstone & $54,596,000$ \\
\hline 9 & 0 & Bekok & 1976 & Miocene & Sandstone & $91,000,000$ \\
\hline 10 & 0 & Sotong & 1973 & - & - & - \\
\hline 11 & 0 & Malong & 1983 & - & Sandstone & - \\
\hline 12 & G & Belumut & 1971 & - & Sandstone & - \\
\hline 13 & G & Duyong & 1974 & - & Sandstone & $54815.8^{*}$ \\
\hline 14 & $\mathbf{G}$ & Angsi & 1974 & - & Sandstone & - \\
\hline 15 & 0 & Trerebuk & - & - & - & - \\
\hline
\end{tabular}


Table 9. - continued General characteristics of selected oil and gas fields, Northwest Quadrant, Circum-Pacific region (refer to figures 13 and 14)

[Basin number refers to figure 13; field number refers to figure 14; $\mathrm{O}=\mathrm{Oil}, \mathrm{G}=\mathrm{Gas}, \mathrm{O} / \mathrm{G}=\mathrm{Oil}$ and $\mathrm{Gas} ;-$, data not available]

\begin{tabular}{|c|c|c|c|c|c|c|}
\hline $\begin{array}{l}\text { Basin number } \\
\text { Field number }\end{array}$ & $\begin{array}{l}\text { Type } \\
\text { Field }\end{array}$ & Basin-Field name & $\begin{array}{c}\text { Year } \\
\text { discovered } \\
\end{array}$ & Reservoir age & Lithology & $\begin{array}{l}\text { Cumulative } \\
\text { production } 1\end{array}$ \\
\hline 16 & O & Belanak & - & - & - & - \\
\hline 17 & 0 & Udang & 1974 & Oligocene-Miocene & Sandstone & - \\
\hline 132 & & Sarawak Basin & & & & \\
\hline 1 & $\mathbf{G}$ & $M-3-1 X$ & 1980 & Miocene & Carbonate & - \\
\hline 2 & $\boldsymbol{G}$ & F-6-1X (Central Luconia) & 1969 & Miocene & Carbonate & - \\
\hline 3 & $\mathbf{G}$ & F-13-1X & 1969 & Miocene & Carbonate & - \\
\hline 4 & $\mathbf{G}$ & E-11 & 1974 & Miocene & Carbonate & $2302834^{*}$ \\
\hline 5 & $\mathbf{G}$ & B-11-1 & 1980 & Miocene & Carbonate & - \\
\hline 6 & $\mathbf{G}$ & D-12-1 & 1980 & Miocene & Carbonate & - \\
\hline 7 & $\mathbf{G}$ & F-29-1 & 1980 & Miocene & Carbonate & - \\
\hline 8 & $\mathbf{G}$ & M4-1 & 1980 & Miocene & Carbonate & - \\
\hline 9 & $\mathbf{G}$ & M5-1X & 1980 & Miocene & Carbonate & - \\
\hline 10 & $\mathbf{O}$ & Acis South & 1962 & Miocene & Sandstone & - \\
\hline 11 & 0 & $J-4-1 X$ & 1978 & Miocene & Sandstone & - \\
\hline 12 & $\mathbf{0}$ & $\mathrm{J}-12-1$ & 1980 & Miocene & Sandstone & - \\
\hline 13 & $\mathbf{O}$ & Temana & 1972 & Miocene & Sandstone & - \\
\hline 14 & $\mathbf{O}$ & C-8-1 & 1981 & Miocene & Sandstone & - \\
\hline 133 & & Brunei-Sabah Basin & & & & \\
\hline 1 & $\mathbf{O}$ & Miri & 1910 & Miocene-Pliocene & Sandstone & $79,727,300$ \\
\hline 2 & $\mathbf{O}$ & Tukau & 1966 & Miocene-Pliocene & Sandstone & $91,749,000$ \\
\hline 3 & 0 & W. Lutong & 1966 & Miocene-Pliocene & Sandstone & $121,690,000$ \\
\hline 4 & $\mathbf{O}$ & Bakau & 1967 & Miocene-Pliocene & Sandstone & $7,047,000$ \\
\hline 5 & 0 & Bokor & 1971 & Miocene-Pliocene & Sandstone & $34,011,000$ \\
\hline 6 & $\mathbf{O}$ & Betty & 1968 & Miocene-Pliocene & Sandstone & $62,327,000$ \\
\hline 7 & $\mathbf{O}$ & Baram & 1964 & Miocene-Pliocene & Sandstone & $135,989,000$ \\
\hline 8 & $\mathbf{0}$ & Baronia & 1967 & Miocene-Pliocene & Sandstone & $148,770,000$ \\
\hline 9 & $\mathbf{O}$ & Fairley-Baram & 1973 & Miocene-Pliocene & Sandstone & $5,845,000$ \\
\hline 10 & $\mathbf{O}$ & Salbian & 1979 & Miocene-Pliocene & Sandstone & - \\
\hline 11 & $\mathbf{G}$ & Beryl & 1969 & Miocene-Pliocene & Sandstone & - \\
\hline 12 & $\mathbf{G}$ & Fatimah & 1980 & Miocene-Pliocene & Sandstone & - \\
\hline 13 & O & Fairley & 1969 & Miocene & Sandstone & $111,299,000$ \\
\hline 14 & $\mathbf{O}$ & Ampa & 1963 & Miocene & Sandstone & - \\
\hline 15 & $O / G$ & S.W. Ampa & 1963 & Miocene & Sandstone & $529,598,000$ \\
\hline 16 & $O / G$ & Seria & 1929 & Miocene & Sandstone & $981,198,000$ \\
\hline 17 & $\mathbf{O}$ & Tali & - & Miocene & Sandstone & - \\
\hline 18 & O/G & Magpie & 1975 & Miocene & Sandstone & $73,499,000$ \\
\hline 19 & $O$ & Champion & 1970 & Miocene & Sandstone & $299,701,000$ \\
\hline 20 & $\mathbf{G}$ & Samarang Kecil & 1972 & Miocene & Sandstone & - \\
\hline 21 & $\mathbf{G}$ & Glayzer & 1981 & Miocene & Sandstone & - \\
\hline 22 & O & Samarang & 1972 & Miocene & Sandstone & $235,380,000$ \\
\hline 23 & 0 & Ketam & 1977 & Miocene & Sandstone & 901,000 \\
\hline 24 & 0 & Lokan & 1979 & Miocene & Sandstone & - \\
\hline 25 & $\mathbf{O}$ & S.E. Collins & 1981 & Miocene & Sandstone & - \\
\hline 26 & 0 & W. Erb & 1977 & Miocene & Sandstone & $21,620,000$ \\
\hline 27 & 0 & Tembungo & 1971 & Miocene & Sandstone & $31,276,000$ \\
\hline 28 & 0 & S.W. Emerald & 1980 & Miocene & Sandstone & - \\
\hline 29 & 0 & St. Joseph & 1975 & Miocene & Sandstone & $20,271,000$ \\
\hline 30 & $\mathbf{O}$ & S. Furious & 1974 & Miocene & Sandstone & $13,499,000$ \\
\hline 31 & 0 & Barton & 1971 & Miocene & Sandstone & $10,402,000$ \\
\hline
\end{tabular}


Table 9.-continued General characteristics of selected oil and gas fields, Northwest Quadrant, Circum-Pacific region (refer to figures 13 and 14)

[Basin number refers to figure 13; field number refers to figure $14 ; \mathrm{O}=\mathrm{Oil}, \mathrm{G}=\mathrm{Gas}, \mathrm{O} / \mathrm{G}=\mathrm{Oil}$ and $\mathrm{Gas} ;-$, data not available]

\begin{tabular}{|c|c|c|c|c|c|c|}
\hline $\begin{array}{l}\text { Basin number } \\
\text { Field number }\end{array}$ & $\begin{array}{l}\text { Type } \\
\text { Field } \\
\end{array}$ & Basin-Field name & $\begin{array}{c}\text { Year } \\
\text { discovered }\end{array}$ & Reservoir age & Lithology & $\begin{array}{l}\text { Cumulative } \\
\text { production } 1\end{array}$ \\
\hline 134 & & North Sumatra Basin & & & & \\
\hline 1 & $\boldsymbol{G}$ & Arun & 1971 & Miocene & Carbonate & $335,835,117$ \\
\hline 2 & 0 & Tualang & 1973 & Miocene & Sandstone & $29,985,653$ \\
\hline 3 & 0 & Iee Tabeue & 1971 & Miocene & Sandstone & $11,897,472$ \\
\hline 4 & 0 & Rantau & 1929 & Miocene-Pliocene & Sandstone & $238,240,510$ \\
\hline 5 & $\mathbf{0}$ & Serang Jaya & 1926 & Miocene-Pliocene & Sandstone & $3,640,310$ \\
\hline 6 & 0 & P. Tabuhan & 1937 & Miocene-Pliocene & Sandstone & $26,553,070$ \\
\hline 136 & & Central Sumatra Basin & & & & \\
\hline 1 & 0 & Bangko & 1970 & Miocene & Sandstone & $346,229,390$ \\
\hline 2 & 0 & Balam South & 1969 & Miocene & Sandstone & $98,472,165$ \\
\hline 3 & 0 & Menggala & 1968 & Miocene & Sandstone & $7,999,690$ \\
\hline 4 & 0 & Sintong & 1971 & Miocene & Sandstone & $54,655,550$ \\
\hline 5 & $\mathbf{0}$ & Pematang & 1959 & Miocene & Sandstone & $218,644,450$ \\
\hline 6 & 0 & Petani & 1964 & Miocene & Sandstone & $273,691,320$ \\
\hline 7 & 0 & Kulin & 1970 & Miocene & Sandstone & $31,524,395$ \\
\hline 8 & 0 & Bekasap & 1955 & Miocene & Sandstone & $406,933,685$ \\
\hline 9 & $O$ & Duri & 1941 & Miocene & Sandstone & $472,448,085$ \\
\hline 10 & 0 & Pungut & 1951 & Miocene & Sandstone & $46,518,425$ \\
\hline 11 & 0 & Petapahan & 1971 & Miocene-Pliocene & Sandstone & $92,703,400$ \\
\hline 12 & 0 & Kotabatak & 1952 & Miocene & Sandstone & $136,355,390$ \\
\hline 13 & $O / G$ & Minas & 1944 & Miocene-Pliocene & Sandstone & $3,332,145,345$ \\
\hline 14 & 0 & Go Tam & 1980 & Miocene-Pliocene & Sandstone & - \\
\hline 15 & 0 & Beruk & 1974 & Miocene-Pliocene & Sandstone & $47,694,545$ \\
\hline 16 & 0 & Zamrud & 1975 & Miocene-Pliocene & Sandstone & $64,899,790$ \\
\hline 17 & $\mathbf{0}$ & N. Pulai & 1941 & Miocene-Pliocene & Sandstone & $37,199,610$ \\
\hline 18 & $\mathbf{O}$ & S. Pulai & 1941 & Miocene-Pliocene & Sandstone & $4,949,860$ \\
\hline 19 & $\mathbf{0}$ & Lirik & 1939 & Miocene & Sandstone & $38,146,330$ \\
\hline 20 & $\mathbf{0}$ & Sago & 1940 & Miocene & Sandstone & $122,391,750$ \\
\hline 21 & 0 & Molek & 1956 & Miocene-Pliocene & Sandstone & $11,724,530$ \\
\hline 22 & 0 & Binio & 1972 & Miocene-Pliocene & Sandstone & $11,820,840$ \\
\hline 137 & & South Sumatra Basin & & & & \\
\hline 1 & 0 & Kenali Asam & 1931 & - & - & $93,495,150$ \\
\hline 2 & 0 & Tempino & 1931 & - & - & $86,285,370$ \\
\hline 3 & $\mathbf{0}$ & Mangundjaja & 1934 & - & - & $23,010,846$ \\
\hline 4 & 0 & Kluang & 1913 & - & - & $33,853,017$ \\
\hline 5 & $\mathbf{0}$ & Ramba & 1982 & Oligocene-Miocene & Sandstone & $44,790,645$ \\
\hline 6 & 0 & Tanjung Laban & 1982 & - & - & $6,258,109$ \\
\hline 7 & 0 & Benakat & 1932 & Miocene & Sandstone-carbonate & $133,729,970$ \\
\hline 8 & 0 & Rambutan & 1972 & - & - & $3,222,896$ \\
\hline 9 & 0 & Abab & 1951 & Oligocene-Miocene & Sandstone & $38,589,560$ \\
\hline 10 & $\mathbf{O}$ & Benuang & 1942 & Oligocene-Miocene & Sandstone & $7,626,590$ \\
\hline 11 & 0 & G. Kemala & 1938 & - & - & $27,235,250$ \\
\hline 12 & $\mathbf{0}$ & T. Jimar & 1937 & Miocene & Sandstone & $171,283,970$ \\
\hline 13 & 0 & Limau & 1928 & Miocene & Sandstone & $188,056,910$ \\
\hline 14 & $\mathbf{O}$ & Ogan & 1943 & - & - & $3,935,790$ \\
\hline 15 & 0 & T. Tiga & 1948 & Miocene & Carbonate & $53,956,521$ \\
\hline 16 & $\mathbf{0}$ & T. Miring & 1935 & - & Sandstone & $11,379,770$ \\
\hline 17 & $\mathbf{O}$ & Belimbing & 1965 & Oligocene-Miocene & Sandstone & $20,834,860$ \\
\hline 18 & $O$ & Kuang & 1940 & Oligocene-Miocene & Sandstone & $7,120,130$ \\
\hline
\end{tabular}


Table 9.-continued General characteristics of selected oil and gas fields, Northwest Quadrant, Circum-Pacific region (refer to figures 13 and 14)

[Basin number refers to figure 13; field number refers to figure 14;O=Oil, $\mathrm{G}=\mathrm{Gas}, \mathrm{O} / \mathrm{G}=\mathrm{Oil}$ and $\mathrm{Gas} ;-$, data not available]

\begin{tabular}{|c|c|c|c|c|c|c|}
\hline $\begin{array}{l}\text { Basin number } \\
\text { Field number }\end{array}$ & $\begin{array}{l}\text { Type } \\
\text { Field } \\
\end{array}$ & Basin-Field name & $\begin{array}{c}\text { Year } \\
\text { discovered }\end{array}$ & Reservoir age & Lithology & $\begin{array}{r}\text { Cumulative } \\
\text { p roduction } 1\end{array}$ \\
\hline 139 & & Sunda Basin & & & & \\
\hline 1 & 0 & Sundari & 1982 & - & - & $10,782,195$ \\
\hline 2 & 0 & Karmila & 1983 & - & - & $29,728,296$ \\
\hline 3 & 0 & Farida & 1982 & - & - & $11,632,953$ \\
\hline 4 & 0 & Yvonne & 1980 & - & - & $12,621,026$ \\
\hline 5 & 0 & Krisna & 1976 & - & - & $59,655,016$ \\
\hline 6 & 0 & Titi & 1982 & - & - & $1,654,547$ \\
\hline 7 & 0 & Zelda & 1971 & Oligocene-Miocene & Sandstone-carbonate & $36,647,449$ \\
\hline 8 & 0 & Wanda & 1984 & - & - & $1,585,811$ \\
\hline 9 & $\mathbf{0}$ & Cinta & 1970 & Miocene & Sandstone-carbonate & $175,971,048$ \\
\hline 10 & 0 & Kitty & 1971 & Miocene & Sandstone-carbonate & $13,973,095$ \\
\hline 11 & 0 & Selatan & 1971 & - & - & $20,797,606$ \\
\hline 12 & 0 & Gita & 1972 & Miocene & Sands̄tone-carbonate & $7,504,813$ \\
\hline 13 & 0 & Duma & 1983 & - & - & 698,312 \\
\hline 14 & $O / G$ & Rama & 1974 & Oligocene-Miocene & Carbonate & $91,186,520$ \\
\hline 15 & 0 & Nora & 1973 & Miocene & Carbonate & $8,807,389$ \\
\hline 140 & & Northwest Java Basin & & & & \\
\hline 1 & $O / G$ & Ardjuna & 1969 & Miocene & Sandstone-carbonate & $683,283,000$ \\
\hline 2 & $\mathbf{0}$ & Arimbi & 1972 & Miocene & Carbonate & $26,331,000$ \\
\hline 3 & $O K G$ & Jatibarang & 1969 & Oligocene & Volcanics-carbonate & $86,509,260$ \\
\hline 143 & & Northeast Java Basin & & & & \\
\hline 1 & $\mathbf{0}$ & Todanan & - & - & - & - \\
\hline 2 & 0 & Tjepu & - & - & - & - \\
\hline 3 & 0 & Blora & - & - & - & - \\
\hline 4 & $\mathbf{O}$ & Rembang & - & - & - & - \\
\hline 5 & 0 & Tanjungan & - & - & - & - \\
\hline 6 & 0 & Kalitidu & - & - & - & - \\
\hline 7 & 0 & Gresik & - & - & - & - \\
\hline 8 & 0 & Redco & - & - & - & - \\
\hline 9 & $\mathbf{0}$ & Surabaja & - & - & - & - \\
\hline 10 & 0 & Waron & - & - & - & - \\
\hline 148 & & Timor Basin & & & & \\
\hline 1 & 0 & Matai & 1961 & Triassic & - & - \\
\hline 2 & $\mathbf{0}$ & Ossulan & - & - & - & - \\
\hline 3 & $\mathbf{O}$ & Aliambata & - & - & - & - \\
\hline 151 & & Tarakan Basin & & & & \\
\hline 1 & 0 & Mengatal & 1974 & Miocene & Sandstone & - \\
\hline 2 & 0 & Bunju & 1922 & - & - & - \\
\hline 3 & 0 & Pamusian & 1905 & Pliocene & Sandstone & - \\
\hline 152 & & Kutei Basin & & & & \\
\hline 1 & $\mathbf{O}$ & Kerindingan & 1972 & Pliocene & Sandstone & $4,940,230$ \\
\hline 2 & o & Melahin & 1972 & Pliocene & Sandstone & $6,513,220$ \\
\hline 3 & $O$ & Attaka & 1970 & Pliocene & Sandstone & $451,865,821$ \\
\hline 4 & $O$ & Nilam & 1974 & - & - & $20,347,122$ \\
\hline 5 & $O$ & Handil & 1974 & Pliocene & Sandstone & $654,495,230$ \\
\hline 6 & $\mathbf{O}$ & Pamaguan & 1974 & Miocene & Sandstone & $6,622,202$ \\
\hline 7 & 0 & Sanga-Sanga & 1897 & Miocene-Pliocene & Sandstone & $267,623,502$ \\
\hline 8 & $\mathbf{0}$ & Sambodja & 1909 & Miocene-Pliocene & Sandstone & $64,542,145$ \\
\hline 9 & 0 & Sepinggan & 1973 & Pliocene & Sandstone & $43,703,543$ \\
\hline 10 & 0 & Bekapai & 1972 & Miocene-Pliocene & Sandstone & $156,640,170$ \\
\hline
\end{tabular}


Table 9.-continued General characteristics of selected oil and gas fields, Northwest Quadrant, Circum-Pacific region (refer to figures 13 and 14)

[Basin number refers to figure 13; field number refers to figure 14;O=Oil, G=Gas, $\mathrm{O} / \mathrm{G}=\mathrm{Oil}$ and $\mathrm{Gas} ;-$, data not available]

\begin{tabular}{|c|c|c|c|c|c|c|}
\hline $\begin{array}{l}\text { Basin number } \\
\text { Field number }\end{array}$ & $\begin{array}{l}\text { Type } \\
\text { Field }\end{array}$ & Basin-Field name & $\begin{array}{c}\text { Year } \\
\text { discovered }\end{array}$ & Reservoir age & Lithology & $\begin{array}{l}\text { Cumulative } \\
\text { production } 1\end{array}$ \\
\hline 11 & $O / G$ & Badak & 1972 & Miocene-Pliocene & Sandstone & $39,600,000$ \\
\hline 156 & & Barito Basin & & & & \\
\hline 1 & 0 & Tanjung & 1938 & Eocene & Sandstone & $102,463,940$ \\
\hline 174 & & Salawati Basin & & & & \\
\hline 1 & 0 & Kasim & 1972 & Miocene & Carbonate & $47,242,198$ \\
\hline 2 & 0 & Jaya & 1973 & Miocene & Carbonate & $25,802,223$ \\
\hline 3 & 0 & Klamono & 1936 & Miocene & Carbonate & $34,910,590$ \\
\hline 4 & 0 & Walio & 1972 & Miocene & Carbonate & $152,075,105$ \\
\hline 5 & 0 & Sele & 1954 & Miocene & Carbonate & $1,421,940$ \\
\hline 175 & & Bintuni Basin & & & & \\
\hline 1 & 0 & Wasian & 1939 & Miocene & Carbonate & - \\
\hline 2 & 0 & Mogo & 1941 & Miocene & Carbonate & - \\
\hline 177 & & Seram Basin & & & & \\
\hline 1 & 0 & Bula & 1897 & Pliocene-Pleistocene & Sandstone-carbonate & $15,090,196$ \\
\hline 186 & & Akimegah Basin & & & & \\
\hline 1 & G & Juha & 1983 & Jurassic-Cretaceous & Sandstone & - \\
\hline 193 & & Papuan Basin & & & & \\
\hline 1 & G & Iehi & 1960 & Jurassic-Cretaceous & Sandstone & - \\
\hline 2 & G & Bwata & 1960 & Miocene & Carbonate & - \\
\hline 3 & G & Kuru & 1956 & Miocene & Carbonate & - \\
\hline 4 & G & Uramu & 1968 & Miocene & Carbonate & - \\
\hline 5 & G & Puri & 1958 & Miocene & Carbonate & - \\
\hline 6 & O/G & Pasca & 1968 & Miocene & Carbonate & - \\
\hline 7 & G & Pandora & 1988 & Miocene & Carbonate & - \\
\hline 8 & O/G & Hedinia & 1987 & Jurassic-Cretaceous & Sandstone & - \\
\hline 9 & $\mathbf{O} / \mathbf{G}$ & Iagifu & 1986 & Jurassic-Cretaceous & Sandstone & - \\
\hline
\end{tabular}

${ }^{1}$ As of December 31,1988 , in barrels.

* Million cubic feet of gas.

† Italics indicate giant oil fields (more than 500 million barrels and (or) 3 trillion cubic feet of gas estimated ultimate recovery). Source: Carmalt, S.W., and St. John, Bill, 1986, Giant oil and gas fields, in Halbouty, M. T., ed., Future petroleum provinces of the world, Proceedings of the Wallace E. Pratt Memorial Conference, Phoenix, Arizona, December 1984: AAPG Memoir 40, p. 11-53. Sources of data:

Penwell Publishing Co., Energy Group, 1991, International petroleum encyclopedia: Tulsa, Okla., Penwell Publishing Co., v. 24, 368 p. Tiratsoo, E.N., 1984, Oilfields of the world: Beaconsfield, England, Scientific Press, Ltd., 392 p. 
Table 10. Sedimentary basins, Southwest Quadrant, Circum-Pacific region

\begin{aligned} & 1 Adavale Basin \\ & 2 Amadeus Basin \\ & 3 Arafura Basin \\ & 4 Arckaringa Basin \\ & 5 Arrowie Basin \\ & 6 Bancannia Trough \\ & 7 Barka Basin \\ & 8 Berri Embayment \\ & 9 Biloela Basin \\ & 10 Birrindudu Basin \\ & 11 Bonaparte Basin \\ & 12 Bowen Basin \\ & 13 Bremer Basin \\ & 14 Canning Basin \\ & 15 Carnarvon Basin \\ & 16 Carpentaria Basin \\ & 17 Clarence-Moreton Basin \\ & 18 Collie Basin \\ & 19 Cooper Basin \\ & 20 Cowell Basin \\ & 21 Daly River Basin \\ & 22 Darling Basin \\ & 23 Denman Basin \\ & 24 Drummond Basin \\ & 25 Duaringa Basin \\ & 26 Eromanga Basin \\ & 27 Esk Trough \\ & 28 Eucla Basin \\ & 29 Galilee Basin \\ & 30 Georgina Basin \\ & 31 Gippsland Basin \\ & 32 Gunnedah Basin \\ & 33 Ivanhoe Basin \\ & 34 Karumba Basin \\ & 35 Kimberley Basin \\ & \\ & \hline\end{aligned}

$\begin{array}{ll}36 & \text { Laura Basin } \\ 37 & \text { Lorne Basin } \\ 38 & \text { Mallabie Depression } \\ 39 & \text { Maryborough Basin } \\ 40 & \text { Macarthur Basin } \\ 41 & \text { Money Shoal Basin } \\ 42 & \text { Murray Basin } \\ 43 & \text { Nadda Basin } \\ 44 & \text { Nambour Basin } \\ 45 & \text { Namurkah Trough } \\ 46 & \text { Ngalia Basin } \\ 47 & \text { Oaklands Basin } \\ 48 & \text { Officer Basin } \\ 49 & \text { Ord Basin } \\ 50 & \text { Otway Basin } \\ 51 & \text { Pedirka Basin } \\ 52 & \text { Perth Basin } \\ 53 & \text { Pirie Torrens Basin } \\ 54 & \text { Polda Basin } \\ 55 & \text { Simpson Basin } \\ 56 & \text { St. Vincent Basin } \\ 57 & \text { Stansbury Basin } \\ 58 & \text { Styx Basin } \\ 59 & \text { Surat Basin } \\ 60 & \text { Sydney Basin } \\ 61 & \text { Tarrara Basin } \\ 62 & \text { Tasmania Basin } \\ 63 & \text { Torrens Basin } \\ 64 & \text { Troubridge Basin } \\ 65 & \text { Victoria River Basin } \\ 66 & \text { Warburton Basin } \\ 67 & \text { Warrabin Basin } \\ 68 & \text { Wiso Basin } \\ 69 & \text { Ashburton Trough } \\ 70 & \text { Nabberu Basin } \\ & \end{array}$

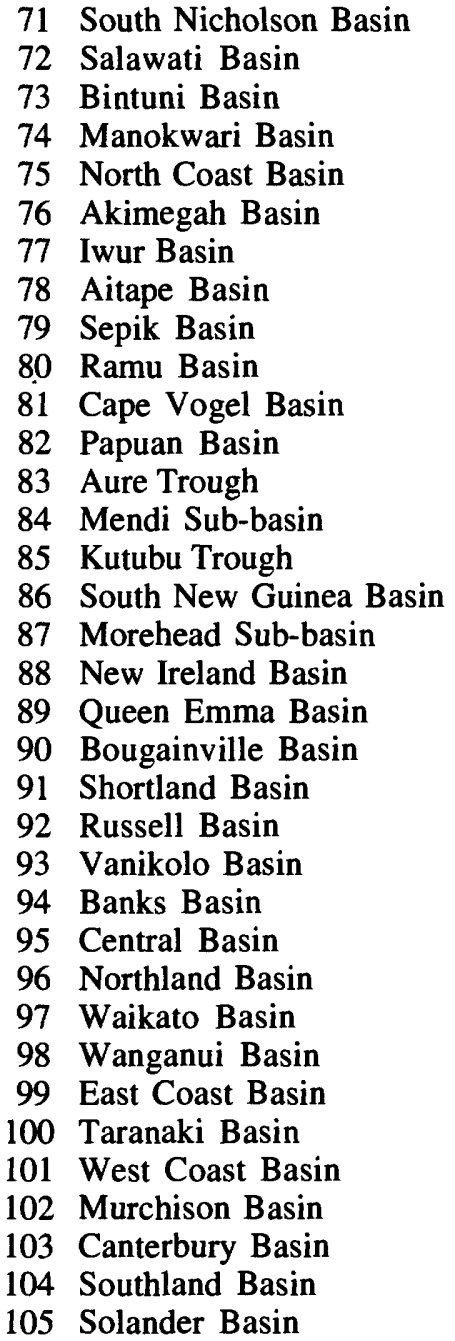


Table 11. Major oil and gas fields, Southwest Quadrant, Circum-Pacific region

\begin{tabular}{|c|c|c|c|}
\hline $\begin{array}{c}\text { Basin/Field/ } \\
\text { Discovery year }\end{array}$ & Age & Lithology & $\begin{array}{c}\text { Cumulative } \\
\text { production }\end{array}$ \\
\hline \multicolumn{4}{|l|}{ Salawati Basin } \\
\hline Kasim 1972 & Miocene & Carbonate & $47,242,198$ \\
\hline Jaya 1973 & Miocene & Carbonate & $25,802,223$ \\
\hline Klamono 1936 & Miocene & Carbonate & $34,910,590$ \\
\hline Walio 1972 & Mioccne & Carbonate & $152,075, \mathrm{I} 05$ \\
\hline \multicolumn{4}{|l|}{ Bintuni Basin } \\
\hline Wasian 1939 & Miocene & Carbonate & - \\
\hline Mogo 1941 & Miocene & Carbonate & - \\
\hline \multicolumn{4}{|l|}{ Akimegah Basin } \\
\hline $\begin{array}{l}\text { Juha } 1983 \\
\text { Papuan Basin }\end{array}$ & Jurassic-Cretaceous & Sandstone & - \\
\hline Iehi 1960 & Jurassic-Cretaceous & Sandstone & - \\
\hline Bwata 1960 & Miocene & Carbonate & - \\
\hline Kuru 1956 & Miocene & Carbonate & - \\
\hline Uramu 1968 & Miocene & Carbonate & - \\
\hline Puri 1958 & Miocene & Carbonate & - \\
\hline Pasca 1968 & Miocene & Carbonate & - \\
\hline Pandora 1988 & Miocene & Carbonate & - \\
\hline Hedinia 1987 & Jurassic-Cretaceous & Sandstone & - \\
\hline Iagifu 1986 & Jurassic-Cretaceous & Sandstone & - \\
\hline \multicolumn{4}{|l|}{ Amadeus Basin } \\
\hline Mereenie 1964 & Ordovician & Sandstone. & $5,152,475$ \\
\hline $\begin{array}{l}\text { Palm Valley } \\
\text { Bonaparte Basin }\end{array}$ & Ordovician & Sandstone & ? \\
\hline Petrel 1969 & Permian & Sandstone & - \\
\hline \multicolumn{4}{|l|}{$\begin{array}{l}\text { Bowen Basin } \\
\text { Canning Basin }\end{array}$} \\
\hline \multicolumn{4}{|l|}{ Carnarvon Basin } \\
\hline Goodwyn 1971 & Triassic & Sandstone & - \\
\hline North Rankin 1972 & Triassic & Sandstone & $37,000,000$ \\
\hline \multicolumn{4}{|l|}{ Cooper/Eromanga Basin } \\
\hline Gidgealpa 1964 & Permian & Sandstone & - \\
\hline Moomba 1964 & Permian & Sandstone & - \\
\hline \multicolumn{4}{|l|}{ Gippsland Basin } \\
\hline Barracouta 1965 & & & $35,498,000$ \\
\hline Bream 1969 & & & $20,260,000$ \\
\hline Cobia 1972 & & & $94,456,000$ \\
\hline Dolphin 1967 & & & $2,788,000$ \\
\hline Flounder 1968 & & & $36,487,000$ \\
\hline Fortescue 1978 & & & $206,886,000$ \\
\hline Halibut 1967 & Eocene & Sandstone & $733,447,000$ \\
\hline Kingfish 1967 & Eocene & Sandstone & $979,933,000$ \\
\hline Mackerel 1969 & & & $397,849,000$ \\
\hline Marlin 1966 & Eocene & Sandstone & $64,647,000$ \\
\hline Perch 1968 & & & $3,341,000$ \\
\hline Seahorse 1978 & & & 260,000 \\
\hline Snapper 1968 & Paleogene & & $18,681,000$ \\
\hline Tarwhine 1981 & & & $18,681,000$ \\
\hline Tuna 1968 & & & $41,647,000$ \\
\hline West Kingfish 1968 & & & $98,527,000$ \\
\hline Whiting 1983 & & & $5,924,000$ \\
\hline \multirow{3}{*}{\multicolumn{4}{|c|}{$\begin{array}{l}\text { Otway Basin } \\
\text { Perth Basin } \\
\text { Surat Basin } \\
\text { Taranaki Basin }\end{array}$}} \\
\hline & & & \\
\hline & & & \\
\hline Maui 1969 & Eocene & Sandstone & _ \\
\hline
\end{tabular}


Table 12. Estimated petroleum resources, proved and probable by basin, Southwest Quadrant, Circum-Pacific region

\begin{tabular}{lcccc}
\hline \multicolumn{1}{c}{ Country/Basin } & $\begin{array}{c}\text { Crude oil } \\
\text { (millions bbl) }\end{array}$ & $\begin{array}{c}\text { Condensate } \\
\text { (millions bbl) }\end{array}$ & $\begin{array}{c}\text { LPG } \\
\text { (millions bbl) }\end{array}$ & $\begin{array}{c}\text { Gas } \\
(10.9 \text { cu. m.) }\end{array}$ \\
\hline Australia & & & & \\
Amadeus/Bonaparte & 189.6 & 2.6 & 8.9 & 12.23 \\
Bowen & 1.4 & 2.4 & 2.5 & 4.96 \\
Canning & 2.6 & - & - & - \\
Carnarvon & 173.5 & 357.2 & 307.3 & 255.92 \\
Cooper/Eromanga & 77.6 & 42.9 & 71.1 & 77.72 \\
Gippsland & 768.6 & 139.6 & 274.9 & 160.5 \\
Otway & - & - & - & 0.97 \\
Perth & 8.7 & $<0.1$ & - & 1.40 \\
Surat & 0.8 & 0.2 & 0.4 & 1.29 \\
New Zealand & & & & $1,222.3$ (mmboe) \\
Taranaki & 277.4 & 210.9 & $?$ & $8,000.0$ (bcf) \\
Papua New Guinea & & & & \\
Papuan & 200 & $?$ & $?$ & \\
\hline
\end{tabular}

Table 13. Estimated proven reserves of oil and gas by country, Southwest Quadrant, Circum-Pacific region

\begin{tabular}{lrr}
\hline \multicolumn{1}{c}{ Country } & Oil $(1,000 \mathrm{bbl})$ & Gas $(\mathrm{bcf})$ \\
\hline Australia & $1,523,700$ & 15,057 \\
Brunei & $1,350,000$ & 11,200 \\
Indonesia & $6,581,293$ & 64,837 \\
Malaysia & $3,045,000$ & 59,055 \\
Burma (Myanmar) & 50,000 & 9,350 \\
New Zealand & 170,230 & 3,449 \\
Papua New Guinea & 200,000 & 8,000 \\
Philippines & 38,000 & 100 \\
Thailand & 262,000 & 13,600 \\
Vietnam & 500,000 & 100 \\
\hline
\end{tabular}


Table 14. List of deposits, Coal Supplement Map, Northeast Quadrant, Circum-Pacific region

\begin{tabular}{|c|c|c|c|c|c|c|c|c|}
\hline $\begin{array}{l}\text { Country } \\
\text { and State }\end{array}$ & $\begin{array}{c}\text { No. of } \\
\text { Occurrence }\end{array}$ & Age & Rank & $\begin{array}{l}\text { No. of } \\
\text { Beds }\end{array}$ & Coking ${ }^{2}$ & $\begin{array}{l}\text { Identified \& } \\
\text { Hypothetical } \\
\text { Resources }^{3}\end{array}$ & $\begin{array}{c}\text { Sulfur } \\
\text { (Percent) }\end{array}$ & $\begin{array}{c}\text { Ash } \\
\text { (Percent) }\end{array}$ \\
\hline \multicolumn{9}{|l|}{ Canada } \\
\hline \multirow{4}{*}{ Alberta } & 31 & Tertiary & Lignite & 2 & $\mathbf{N}$ & & $<1$ & $<15$ \\
\hline & 38 & Tertiary & Lignite & & $\mathrm{N}$ & L & & \\
\hline & 28 & Tertiary & $\begin{array}{l}\text { Lignite- } \\
\text { subbituminous }\end{array}$ & & $\mathrm{N}$ & $\mathbf{M}$ & & \\
\hline & 26 & Tertiary & $\begin{array}{l}\text { Lignite- } \\
\text { subbituminous }\end{array}$ & & $\mathbf{N}$ & L & & \\
\hline \multirow{35}{*}{$\begin{array}{l}\text { British } \\
\text { Columbia }\end{array}$} & & & & & & & & \\
\hline & 43 & Cretaceous & Bituminous & & & L & & \\
\hline & 44 & Tertiary & Lignite & & $\mathrm{N}$ & $\mathbf{S}$ & & \\
\hline & 45 & Tertiary & Lignite & & $\mathrm{N}$ & $\mathbf{S}$ & & \\
\hline & 46 & Tertiary & Lignite & & $\mathrm{N}$ & & & \\
\hline & 47 & $\begin{array}{l}\text { Cretaceous- } \\
\text { Tertiary }\end{array}$ & Bituminous & 3 & & L & & \\
\hline & 48 & Cretaceous & Bituminous & & & L & & \\
\hline & 49 & Cretaceous & Bituminous & 3 & & $\mathbf{s}$ & & \\
\hline & 50 & Cretaceous & Bituminous & 4 & $\mathbf{P}$ & $\mathbf{s}$ & & \\
\hline & 51 & Tertiary & Lignite & 1 & $\mathrm{~N}$ & L & $<3$ & $>15$ \\
\hline & 52 & Cretaceous & Bituminous & 4 & P-E & $\bar{L}$ & $<3$ & $>15$ \\
\hline & 56 & Tertiary & Lignite & & $\mathbf{N}$ & $\mathbf{S}$ & & \\
\hline & 58 & Tertiary & Bituminous & 6 & P-E & L & & \\
\hline & 59 & Cretaceous & Lignite & & $\mathrm{N}$ & L & & \\
\hline & 60 & Tertiary & Lignite & & $N$ & S & & \\
\hline & 62 & $\begin{array}{l}\text { Jurassic- } \\
\text { Cretaceous }\end{array}$ & $\begin{array}{c}\text { Bituminous- } \\
\text { Anthracite }\end{array}$ & 1 & $\mathbf{x}$ & $\mathbf{S}$ & & \\
\hline & 63 & $\begin{array}{l}\text { Jurassic- } \\
\text { Cretaceous }\end{array}$ & $\begin{array}{l}\text { Bituminous- } \\
\text { Anthracite }\end{array}$ & 13 & $\mathbf{x}$ & $\mathbf{L}$ & & \\
\hline & 64 & Tertiary & $\begin{array}{l}\text { Subbituminous- } \\
\text { Bituminous }\end{array}$ & 3 & $\mathrm{~N}$ & L & & \\
\hline & 65 & Tertiary & Lignite & 1 & $\mathrm{~N}$ & L & & \\
\hline & 66 & Cretaceous & Bituminous & 1 & $\mathbf{Y}$ & $\mathbf{M}$ & & \\
\hline & 68 & Tertiary & Subbituminous & Several & $\mathrm{N}$ & $\mathbf{S}$ & & \\
\hline & 69 & Tertiary & Lignite & & $\mathrm{N}$ & $\mathbf{S}$ & & \\
\hline & 71 & Tertiary & Lignite & 1 & $\mathrm{~N}$ & L & & \\
\hline & 72 & Tertiary & Lignite & & $\mathrm{N}$ & $\mathbf{S}$ & & \\
\hline & 76 & Tertiary & Lignite & & $\mathbf{Y}$ & L & & \\
\hline & 82 & Tertiary & Lignite & 5 & $\mathrm{~N}$ & $S$ & & \\
\hline & 84 & Tertiary & Lignite & $15+$ & $\mathrm{N}$ & $\mathbf{M}$ & & \\
\hline & 86 & Cretaceous & Bituminous & 3 & $\mathrm{Y}$ & $\mathrm{s}$ & & \\
\hline & 90 & Tertiary & Bituminous & Numerous & $\mathbf{Y}$ & $\mathbf{M}$ & $<1$ & \\
\hline & 92 & Tertiary & $\begin{array}{l}\text { Lignite- } \\
\text { Bituminous }\end{array}$ & 2 & $\mathbf{Y}$ & S & & \\
\hline & 101 & Cretaceous & Bituminous & & $Y$ & $\mathbf{s}$ & & \\
\hline & 102 & Tertiary & Lignite & & $\mathrm{N}$ & $\mathbf{S}$ & & \\
\hline & 103 & Tertiary & Lignite & & $\mathbf{N}$ & $s$ & & \\
\hline & 107 & Cretaceous & Bituminous & & $\mathrm{Y}$ & s & & \\
\hline & 109 & Mississippian & Bituminous & & $\mathbf{Y}$ & L & & \\
\hline
\end{tabular}


Table 14. - continued List of deposits, Coal Supplement Map, Northeast Quadrant, Circum-Pacific region

\begin{tabular}{|c|c|c|c|c|c|c|c|c|}
\hline $\begin{array}{l}\text { Country } \\
\text { and State }\end{array}$ & $\begin{array}{c}\text { No. of } \\
\text { Occurrence }\end{array}$ & Age & Rank & $\begin{array}{l}\text { No. of } \\
\text { Beds }\end{array}$ & Coking ${ }^{2}$ & $\begin{array}{c}\text { Identified \& } \\
\text { Hypothetical } \\
\text { Resources }^{3}\end{array}$ & $\begin{array}{c}\text { Sulfur } \\
\text { (Percent) }\end{array}$ & $\begin{array}{c}\text { Ash } \\
\text { (Percent) }\end{array}$ \\
\hline \multicolumn{9}{|l|}{ Northwest } \\
\hline \multirow[t]{17}{*}{ Territories } & 122 & Cretaceous & Lignite & & $\mathbf{N}$ & L & & \\
\hline & 123 & Cretaceous & Bituminous & $8+$ & & $\mathrm{L}$ & $<3$ & $>15$ \\
\hline & 154 & Cretaceous & Bituminous & & & $\mathbf{S}$ & & \\
\hline & 155 & Cretaceous & Bituminous & & & L & & \\
\hline & 226 & Tertiary & Lignite & 3 & $\mathbf{N}$ & L & & \\
\hline & 228 & Tertiary & Lignite & & $\mathbf{N}$ & $\mathbf{M}$ & & \\
\hline & 229 & Cretaceous & $\begin{array}{l}\text { Subbituminous- } \\
\text { Bituminous }\end{array}$ & 3 & $\mathbf{N}$ & $\mathbf{M}$ & & \\
\hline & 243 & Tertiary & Lignite & & $\mathbf{N}$ & L & & \\
\hline & 244 & Tertiary & Lignite & & $\mathbf{N}$ & $\mathbf{M}$ & & \\
\hline & 242 & Cretaceous & Lignite & & $\mathbf{N}$ & $\mathrm{L}$ & & \\
\hline & 129 & $\begin{array}{l}\text { Tertiary- } \\
\text { Cretaceous }\end{array}$ & $\begin{array}{l}\text { Lignite- } \\
\text { Subbituminous }\end{array}$ & & $\mathbf{N}$ & $\mathbf{S}$ & & \\
\hline & 133 & $\begin{array}{l}\text { Tertiary- } \\
\text { Cretaceous }\end{array}$ & $\begin{array}{l}\text { Lignite- } \\
\text { Subbituminous }\end{array}$ & & $\mathbf{N}$ & $\mathbf{S}$ & & \\
\hline & 156 & $\begin{array}{l}\text { Tertiary- } \\
\text { Cretaceous }\end{array}$ & Bituminous & & & L & & \\
\hline & 266 & $\begin{array}{l}\text { Devonian- } \\
\text { Cretaceous }\end{array}$ & Bituminous & Many & & L & & \\
\hline & 249 & Devonian & Bituminous & & & L & & \\
\hline & 183 & Devonian & Bituminous & & & L & & \\
\hline & 241 & Cretaceous & Lignite & & $\mathbf{N}$ & L & & \\
\hline \multirow[t]{22}{*}{ Yukon } & 308 & Cretaceous & Lignite & & $\mathbf{N}$ & L & & \\
\hline & 309 & Tertiary & Lignite & 2 & $\mathbf{N}$ & L & & \\
\hline & 310 & $\begin{array}{l}\text { Cretaceous- } \\
\text { Tertiary }\end{array}$ & Lignite & 3 & $\mathbf{N}$ & L & & \\
\hline & 311 & Cretaceous & $\begin{array}{l}\text { Lignite- } \\
\text { Bituminous }\end{array}$ & 3 & $\mathrm{Y}$ & L & $<1$ & $<15$ \\
\hline & 312 & $\begin{array}{c}\text { Cretaceous- } \\
\text { Tertiary }\end{array}$ & $\begin{array}{l}\text { Lignite- } \\
\text { Subbituminous }\end{array}$ & & $\mathbf{N}$ & L & & $<8$ \\
\hline & 313 & Tertiary & Subbituminous & 3 & $\mathbf{N}$ & M & & \\
\hline & 314 & Cretaceous & Anthracite & 3 & $\mathbf{N}$ & $\mathbf{M}$ & & \\
\hline & 315 & Cretaceous & Bituminous & & & $\mathbf{S}$ & & \\
\hline & 319 & Cretaceous & Bituminous & & & L & & \\
\hline & 320 & Tertiary & Lignite & & $N$ & L & & \\
\hline & 324 & Cretaceous & $\begin{array}{l}\text { Subbituminous- } \\
\text { Bituminous }\end{array}$ & 5 & $\mathrm{Y}$ & L & & \\
\hline & 330 & Tertiary & Lignite & & $\mathbf{N}$ & L & & \\
\hline & 331 & Tertiary & Lignite & & $\mathbf{N}$ & L & & \\
\hline & 332 & Cretaceous & Lignite & & $\mathbf{N}$ & $\mathbf{S}$ & & \\
\hline & 337 & Cretaceous & Lignite & & & $\mathbf{S}$ & & \\
\hline & 345 & Tertiary & Subbituminous & 1 & $\mathbf{N}$ & $\mathbf{M}$ & & \\
\hline & 350 & Cretaceous & & & & L & & \\
\hline & 352 & Tertiary & Lignite & & $\mathbf{N}$ & L & & \\
\hline & 353 & Tertiary & Lignite & & $\mathbf{N}$ & L & & \\
\hline & 354 & Tertiary & Lignite & & $\mathbf{N}$ & L & & \\
\hline & 357 & Mississippian & Bituminous & & $\mathrm{Y}$ & M & & \\
\hline & 329 & Cretaceous & Bituminous & 1 & & $\mathbf{M}$ & & \\
\hline Saskatchewan & 282 & Cretaceous & Lignite & Several & $\mathbf{N}$ & $\mathrm{L}$ & & \\
\hline
\end{tabular}


Table 14.-continued List of deposits, Coal Supplement Map, Northeast Quadrant, Circum-Pacific region

\begin{tabular}{|c|c|c|c|c|c|c|c|c|}
\hline $\begin{array}{l}\text { Country } \\
\text { and State }\end{array}$ & $\begin{array}{l}\text { No. of } \\
\text { Occurrence }{ }^{1}\end{array}$ & Age & Rank & $\begin{array}{l}\text { No. of } \\
\text { Beds }\end{array}$ & Coking ${ }^{2}$ & $\begin{array}{l}\text { Hypothetical } \\
\text { Resources }^{3}\end{array}$ & $\begin{array}{c}\text { Sulfur } \\
\text { (Percent) }\end{array}$ & $\begin{array}{c}\text { Age } \\
\text { (Percent) }\end{array}$ \\
\hline \multirow{12}{*}{ Guatemala } & 1 & Tertiary & Lignite & & N & $s$ & $<3$ & $>15$ \\
\hline & 2 & Tertiary & Lignite & & $\mathrm{N}$ & $S$ & & \\
\hline & 4 & Tertiary & Lignite & & $\mathrm{N}$ & $S$ & & \\
\hline & 5 & Tertiary & Lignite & & $\mathrm{N}$ & $\mathbf{S}$ & $>3$ & $>15$ \\
\hline & 6 & Tertiary & Lignite & & $\mathrm{N}$ & $S$ & $<3$ & $>15$ \\
\hline & 8 & Tertiary & Lignite & & $\mathbf{N}$ & $s$ & & \\
\hline & 14 & Tertiary & Lignite & & $\mathrm{N}$ & $\mathbf{S}$ & & \\
\hline & 18 & Tertiary & Lignite & & $\mathbf{N}$ & $\mathbf{s}$ & & \\
\hline & 19 & Tertiary & Lignite & & $\mathrm{N}$ & $S$ & & $<8$ \\
\hline & 22 & Tertiary & Lignite & & $\mathrm{N}$ & $S$ & & \\
\hline & 26 & Tertiary & Lignite & & $\mathrm{N}$ & $S$ & & \\
\hline & 27 & Tertiary & Lignite & & $\mathrm{N}$ & $S$ & & $<15$ \\
\hline \multirow[t]{10}{*}{ Honduras } & 1 & $\begin{array}{c}\text { Triassic- } \\
\text { Jurassic }\end{array}$ & $\begin{array}{l}\text { Subbituminous- } \\
\text { Bituminous }\end{array}$ & 5 & & & & \\
\hline & 2 & $\begin{array}{l}\text { Triassic- } \\
\text { Jurassic }\end{array}$ & Subbituminous & 3 & N & $\mathbf{s}$ & $<3$ & $>15$ \\
\hline & 3 & $\begin{array}{l}\text { Triassic- } \\
\text { Jurassic }\end{array}$ & $\begin{array}{l}\text { Subbituminous- } \\
\text { Bituminous }\end{array}$ & & $\mathrm{N}$ & $\mathbf{S}$ & $<1$ & $>15$ \\
\hline & 4 & $\begin{array}{l}\text { Triassic- } \\
\text { Jurassic }\end{array}$ & Subbituminous & Several & N & $\mathbf{S}$ & $<3$ & $>15$ \\
\hline & 5 & $\begin{array}{l}\text { Triassic- } \\
\text { Jurassic }\end{array}$ & Subbituminous & 1 & $\mathbf{N}$ & $S$ & $<1$ & $>15$ \\
\hline & 8 & $\begin{array}{l}\text { Triassic- } \\
\text { Jurassic }\end{array}$ & Subbituminous & 4 & $\mathbf{N}$ & $s$ & $>3$ & $>15$ \\
\hline & 9 & Tertiary & $\begin{array}{l}\text { Subbituminous- } \\
\text { Bituminous }\end{array}$ & 1 & $\mathbf{N}$ & $S$ & & \\
\hline & 10 & Tertiary & Lignite & & & $S$ & & \\
\hline & 11 & Tertiary & Lignite & & N & $S$ & & \\
\hline & 12 & Tertiary & Lignite & & $\mathrm{N}$ & $\mathbf{S}$ & & \\
\hline \multirow[t]{7}{*}{ Nicaragua } & 1 & Tertiary & Lignite & & $\mathbf{N}$ & $\mathbf{S}$ & & \\
\hline & 2 & Tertiary & Lignite & & $\mathrm{N}$ & $S$ & & \\
\hline & 3 & Tertiary & Lignite & & $\mathbf{N}$ & $\mathbf{S}$ & & \\
\hline & 4 & Tertiary & Lignite & & $\mathrm{N}$ & $\mathbf{S}$ & & \\
\hline & 5 & Tertiary & Lignite & & $\mathrm{N}$ & $S$ & & \\
\hline & 6 & Tertiary & Lignite & & $\mathbf{N}$ & $\mathbf{S}$ & & \\
\hline & 7 & Tertiary & Lignite & & $\mathbf{N}$ & $S$ & & \\
\hline \multirow[t]{6}{*}{ Cuba } & 1 & Tertiary & Lignite & & $\mathbf{N}$ & $\mathbf{S}$ & & \\
\hline & 3 & Tertiary & Lignite & & $\mathbf{N}$ & $S$ & & \\
\hline & 9 & Tertiary & Lignite & & $\mathrm{N}$ & $s$ & & \\
\hline & 11 & Tertiary & Lignite & & $\mathbf{N}$ & $\mathbf{S}$ & & \\
\hline & 13 & Tertiary & Lignite & & $\mathrm{N}$ & $S$ & & \\
\hline & 14 & Tertiary & Lignite & & $\mathrm{N}$ & $\mathbf{S}$ & & \\
\hline
\end{tabular}

Jamaica 
Table 14. - continued List of deposits, Coal Supplement Map, Northeast Quadrant, Circum-Pacific region

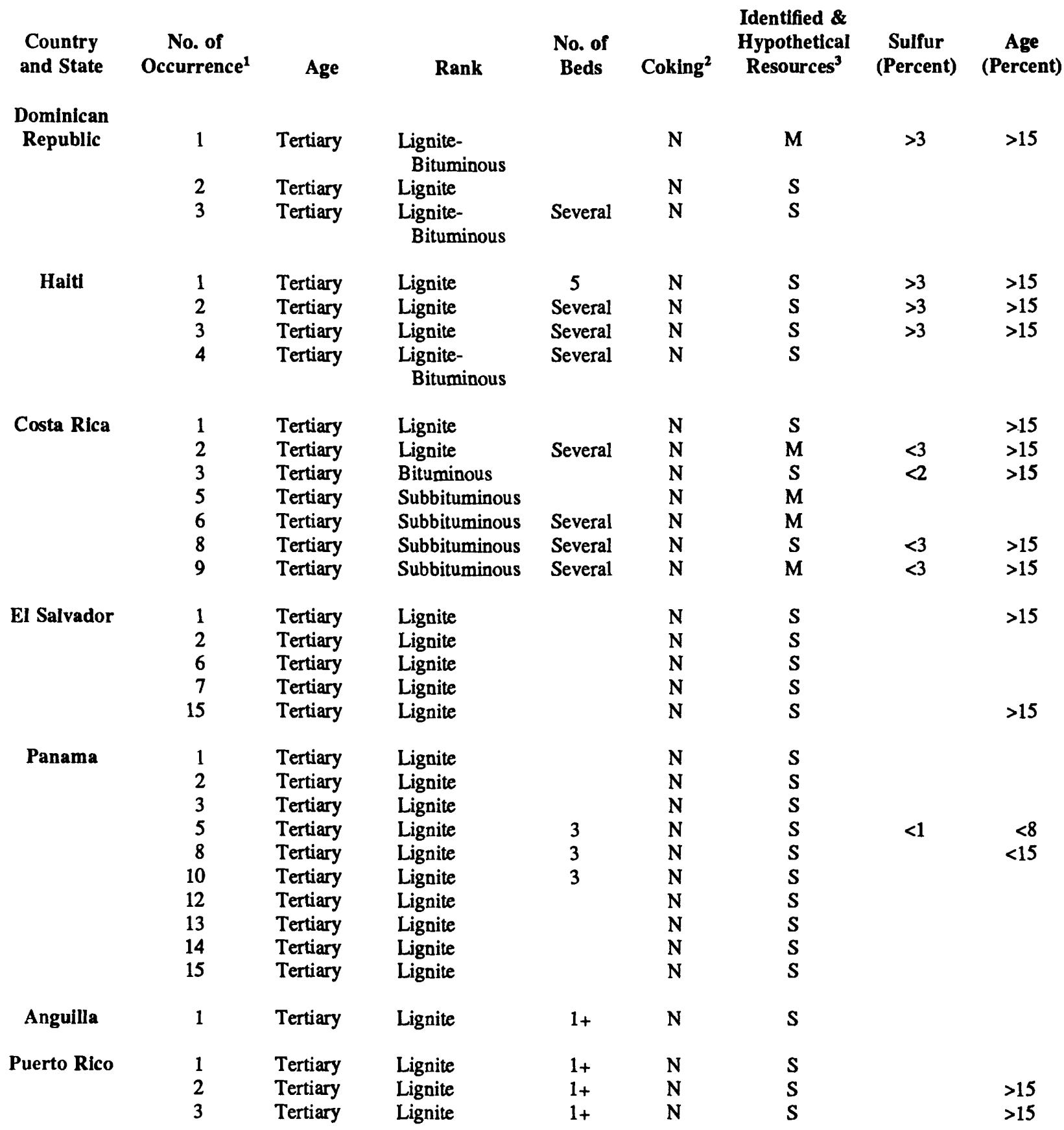

Mexico

$\begin{array}{llll}\text { Chihuahua } & 1 & \text { Tertiary } & \text { Lignite } \\ & 2 & \text { Cretaceous } & \text { Bituminous } \\ & 3 & \text { Jurassic } & \text { Anthracite } \\ 4 & \text { Jurassic } & \text { Anthracite } \\ & 5 & \text { Cretaceous } & \text { Bituminous } \\ & 6 & \text { Tertiary } & \text { Lignite }\end{array}$

$\begin{array}{llll}\text { Chiapas } & 8 & \text { Jurassic } & \text { Bituminous }\end{array}$

$\begin{array}{ll}\text { N } & \text { S } \\ \text { Y } & \text { S } \\ \text { N } & \text { S } \\ \text { N } & \text { S } \\ \text { Y } & \text { L } \\ \text { N } & \text { S } \\ \text { Y } & \text { S }\end{array}$


Table 14. - continued List of deposits, Coal Supplement Map, Northeast Quadrant, Circum-Pacific region

\begin{tabular}{|c|c|c|c|c|c|c|c|c|}
\hline $\begin{array}{l}\text { Country } \\
\text { and State }\end{array}$ & $\begin{array}{l}\text { No. of } \\
\text { Occurrence }\end{array}$ & Age & Rank & $\begin{array}{l}\text { No. of } \\
\text { Beds }\end{array}$ & Coking ${ }^{2}$ & $\begin{array}{l}\text { Identified \& } \\
\text { Hypothetical } \\
\text { Resources }^{3}\end{array}$ & $\begin{array}{c}\text { Sulfur } \\
\text { (Percent) }\end{array}$ & $\begin{array}{c}\text { Age } \\
\text { (Percent) }\end{array}$ \\
\hline \multirow[t]{9}{*}{ Coahuila } & 10 & Cretaceous & Bituminous & 1 & $\mathbf{Y}$ & $\mathbf{S}$ & & \\
\hline & 11 & Cretaceous & Bituminous & 1 & $\mathrm{Y}$ & L & $<2$ & $>15$ \\
\hline & 12 & Cretaceous & Bituminous & 1 & $\mathrm{Y}$ & $\bar{L}$ & $<2$ & $>15$ \\
\hline & 13 & Cretaceous & Bituminous & 1 & Y & L & $<2$ & $>15$ \\
\hline & 14 & Cretaceous & Bituminous & 1 & $\mathbf{Y}$ & $\mathrm{L}$ & $<2$ & $>15$ \\
\hline & 18 & Cretaceous & Bituminous & 1 & $\mathbf{Y}$ & L & $<2$ & $>15$ \\
\hline & 22 & Cretaceous & Subbituminous & 1 & $\mathbf{Y}$ & L & & $>15$ \\
\hline & 23 & Cretaceous & Bituminous & 1 & $\mathbf{Y}$ & $\mathrm{L}$ & & \\
\hline & 24 & Cretaceous & Bituminous & 1 & $\mathrm{Y}$ & L & & \\
\hline Colima & 27 & Tertiary & Lignite & & $\mathrm{N}$ & $S$ & & \\
\hline \multirow[t]{2}{*}{ Durango } & 28 & Tertiary & Lignite & & $\mathbf{N}$ & $\mathbf{s}$ & & \\
\hline & 29 & Cretaceous & Bituminous & & & $S$ & & \\
\hline \multirow{2}{*}{ Guanajuato } & 30 & & & & & $\mathbf{s}$ & & \\
\hline & 31 & Tertiary & Lignite & & $\mathrm{N}$ & $S$ & & \\
\hline \multirow[t]{5}{*}{ Guerrero } & 32 & & Bituminous & & $\mathbf{Y}$ & $\mathbf{s}$ & & \\
\hline & 33 & & Lignite & & $\mathrm{N}$ & $\mathbf{S}$ & & \\
\hline & 34 & Tertiary & Lignite & & $\mathrm{N}$ & $s$ & & \\
\hline & 35 & Jurassic & Bituminous & & $\mathrm{Y}$ & S & & \\
\hline & 36 & & & & N & $\mathrm{S}$ & & \\
\hline \multirow[t]{3}{*}{ Hidalgo } & 37 & & Bituminous & & $\mathbf{Y}$ & $s$ & & \\
\hline & 38 & Tertiary & Bituminous & & $\mathbf{Y}$ & $\mathrm{s}$ & & \\
\hline & 39 & Tertiary & Lignite & & $\mathbf{N}$ & S & & \\
\hline \multirow[t]{6}{*}{ Jalisco } & 40 & & & & & $S$ & & \\
\hline & 41 & & & & & S & & \\
\hline & 42 & & & & & $s$ & & \\
\hline & 43 & Cretaceous & Bituminous & & $\mathrm{Y}$ & $S$ & & \\
\hline & 44 & Cretaceous & Bituminous & & $\mathbf{Y}$ & $\mathbf{s}$ & & \\
\hline & 45 & Cretaceous & Bituminous & & $\mathrm{Y}$ & $s$ & & \\
\hline
\end{tabular}

Mexico D. F. $\quad 46$

\begin{tabular}{|c|c|c|c|}
\hline Michoacan & $\begin{array}{l}47 \\
48 \\
50 \\
54 \\
55 \\
56 \\
57 \\
58\end{array}$ & Tertiary & $\begin{array}{l}\text { Anthracite } \\
\text { Bituminous } \\
\text { Lignite } \\
\text { Bituminous } \\
\text { Lignite }\end{array}$ \\
\hline Nayarit & $\begin{array}{l}59 \\
60\end{array}$ & $\begin{array}{l}\text { Tertiary } \\
\text { Tertiary }\end{array}$ & $\begin{array}{l}\text { Lignite } \\
\text { Lignite }\end{array}$ \\
\hline Nuevo Leon & 61 & Cretaceous & Bituminous \\
\hline Oaxaca & $\begin{array}{l}62 \\
64 \\
65 \\
66 \\
67 \\
68 \\
72\end{array}$ & $\begin{array}{l}\text { Jurassic } \\
\text { Jurassic } \\
\text { Tertiary } \\
\text { Jurassic } \\
\text { Jurassic } \\
\text { Jurassic }\end{array}$ & $\begin{array}{l}\text { Bituminous } \\
\text { Bituminous } \\
\text { Bituminous } \\
\text { Bituminous } \\
\text { Bituminous } \\
\text { Bituminous } \\
\text { Bituminous }\end{array}$ \\
\hline
\end{tabular}

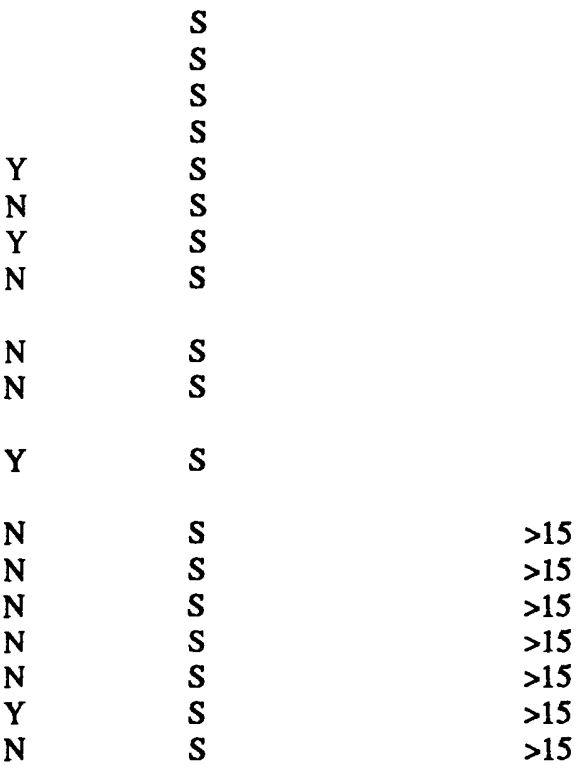


Table 14.-continued List of deposits, Coal Supplement Map, Northeast Quadrant, Circum-Pacific region

\begin{tabular}{|c|c|c|c|c|c|c|c|c|}
\hline $\begin{array}{l}\text { Country } \\
\text { and State }\end{array}$ & $\begin{array}{c}\text { No. of } \\
\text { Occurrence }^{1}\end{array}$ & Age & Rank & $\begin{array}{l}\text { No. of } \\
\text { Beds }\end{array}$ & Coking ${ }^{2}$ & $\begin{array}{c}\text { Identified \& } \\
\text { Hypothetical } \\
\text { Resources }^{3}\end{array}$ & $\begin{array}{c}\text { Sulfur } \\
\text { (Percent) }\end{array}$ & $\begin{array}{c}\text { Age } \\
\text { (Percent) }\end{array}$ \\
\hline Puebla & $\begin{array}{r}86 \\
90 \\
130 \\
131\end{array}$ & $\begin{array}{l}\text { Jurassic } \\
\text { Tertiary }\end{array}$ & $\begin{array}{l}\text { Bituminous } \\
\text { Lignite }\end{array}$ & & $\begin{array}{l}\mathbf{Y} \\
\mathbf{N}\end{array}$ & $\begin{array}{l}S \\
S \\
S \\
S\end{array}$ & & \\
\hline Querretaro & $\begin{array}{l}94 \\
96\end{array}$ & & $\begin{array}{l}\text { Bituminous } \\
\text { Lignite }\end{array}$ & & $\mathrm{N}$ & $\begin{array}{l}\mathbf{S} \\
\mathbf{S}\end{array}$ & & \\
\hline Sonora & $\begin{array}{l}98 \\
99\end{array}$ & $\begin{array}{l}\text { Cretaceous } \\
\text { Triassic }\end{array}$ & Anthracite & & $\mathbf{N}$ & $S$ & & \\
\hline & $\begin{array}{l}100 \\
101\end{array}$ & $\begin{array}{l}\text { Triassic } \\
\text { Triassic }\end{array}$ & $\begin{array}{l}\text { Anthracite } \\
\text { Anthracite }\end{array}$ & $\begin{array}{r}9+ \\
10_{+}\end{array}$ & $\begin{array}{l}\mathbf{N} \\
\mathbf{N}\end{array}$ & $\begin{array}{l}\mathrm{L} \\
\mathrm{M}\end{array}$ & $\begin{array}{l}<1 \\
<3\end{array}$ & $\begin{array}{l}>15 \\
>15\end{array}$ \\
\hline $\begin{array}{l}\text { San Luis } \\
\text { Potosi }\end{array}$ & 116 & Cretaceous & Lignite & & $\mathbf{N}$ & $S$ & & \\
\hline Tabasco & 117 & Tertiary & Lignite & & $\mathrm{N}$ & $S$ & & \\
\hline Tamaulipas & $\begin{array}{l}118 \\
120 \\
121\end{array}$ & $\begin{array}{l}\text { Tertiary } \\
\text { Cretaceous } \\
\text { Cretaceous }\end{array}$ & $\begin{array}{l}\text { Lignite } \\
\text { Bituminous } \\
\text { Bituminous }\end{array}$ & & $\begin{array}{l}\mathbf{N} \\
\mathbf{Y} \\
\mathbf{Y}\end{array}$ & $\begin{array}{l}\text { L } \\
\text { S } \\
\text { S }\end{array}$ & $<2$ & $>15$ \\
\hline Vera Cruz & $\begin{array}{l}122 \\
123 \\
124 \\
127 \\
128\end{array}$ & $\begin{array}{l}\text { Jurassic } \\
\text { Cretaceous } \\
\text { Tertiary }\end{array}$ & $\begin{array}{l}\text { Bituminous } \\
\text { Lignite }\end{array}$ & & $\begin{array}{l}Y \\
N\end{array}$ & $\begin{array}{l}\mathbf{S} \\
\mathbf{S} \\
\mathbf{S} \\
\mathbf{S} \\
\mathbf{S}\end{array}$ & & \\
\hline
\end{tabular}

United States

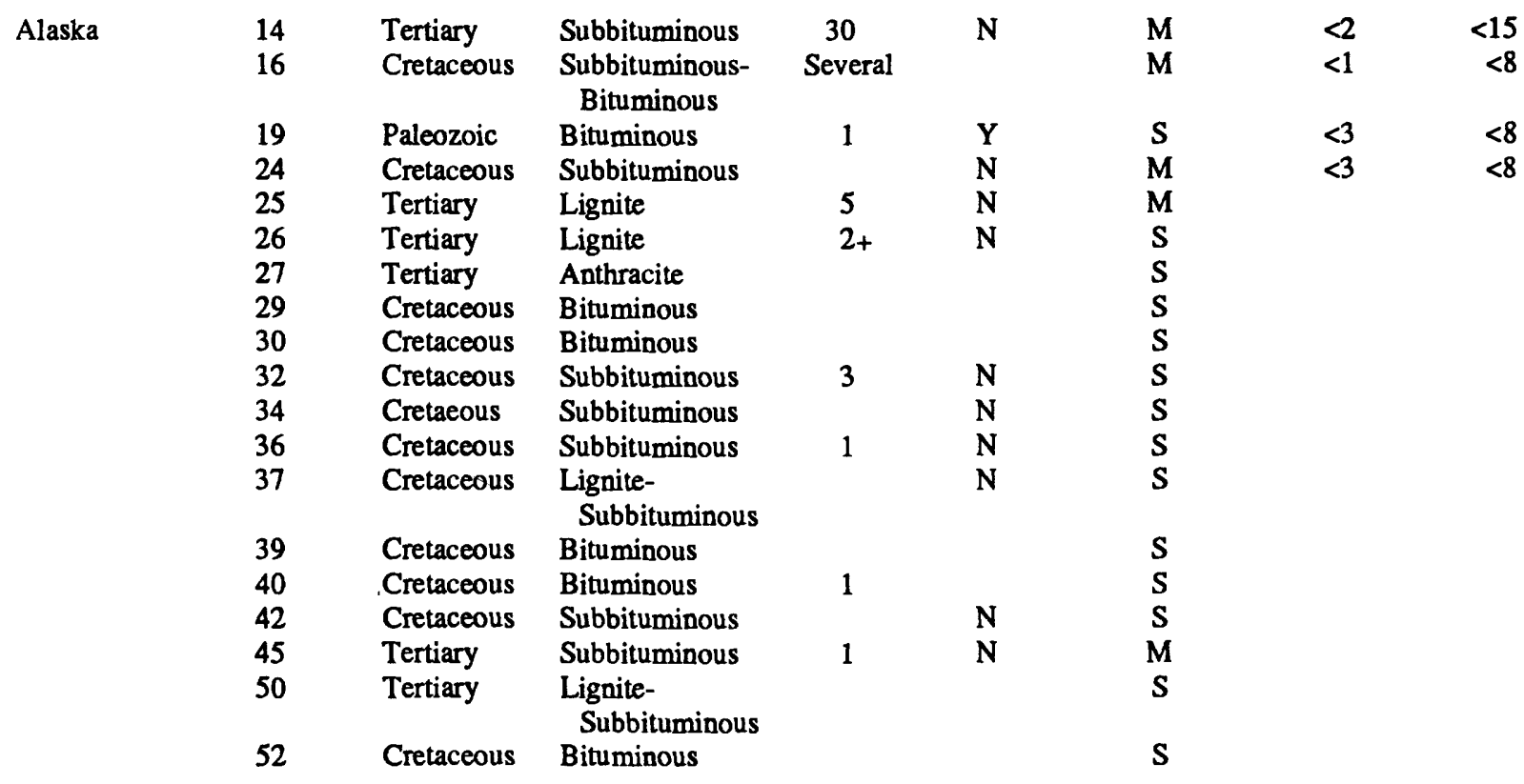


Table 14. - continued List of deposits, Coal Supplement Map, Northeast Quadrant, Circum-Pacific region

\begin{tabular}{|c|c|c|c|c|c|c|c|c|}
\hline $\begin{array}{c}\text { Country } \\
\text { and State }\end{array}$ & $\begin{array}{c}\text { No. of } \\
\text { Occurrence }^{1}\end{array}$ & Age & Rank & $\begin{array}{l}\text { No. of } \\
\text { Beds }\end{array}$ & Coking $^{2}$ & $\begin{array}{l}\text { Identified \& } \\
\text { Hypothetical } \\
\text { Resources }^{3}\end{array}$ & $\begin{array}{c}\text { Sulfur } \\
\text { (Percent) }\end{array}$ & $\begin{array}{c}\text { Age } \\
\text { (Percent) }\end{array}$ \\
\hline \multirow[t]{6}{*}{ Arizona } & 59 & Cretaceous & & & $\mathrm{N}$ & $\mathbf{S}$ & & \\
\hline & 60 & Cretaceous & Bituminous & $1+$ & & L & $>3$ & \\
\hline & 61 & Cretaceous & Bituminous & $2+$ & $\mathbf{M}$ & $\mathbf{M}$ & $>3$ & $>15$ \\
\hline & 62 & Permian & Lignite & 1 & $\mathbf{N}$ & $\mathbf{M}$ & & $>15$ \\
\hline & 65 & Cretaceous & Subbituminous & $2+$ & $\mathrm{N}$ & $\mathbf{M}$ & & $>15$ \\
\hline & 68 & Cretaceous & & & & $\mathbf{S}$ & & \\
\hline \multirow[t]{11}{*}{ California } & 79 & Tertiary & Bituminous & 1 & & $\mathbf{M}$ & $>3$ & $>15$ \\
\hline & 80 & Tertiary & Bituminous & & & $\mathbf{S}$ & & \\
\hline & 82 & Tertiary & Lignite & 2 & $\mathbf{N}$ & $\mathbf{M}$ & $<3$ & $>15$ \\
\hline & 83 & Tertiary & Subbituminous & $2+$ & $\mathbf{N}$ & $\mathbf{M}$ & $<3$ & $<15$ \\
\hline & 84 & Tertiary & Subbituminous & $1+$ & $\mathbf{N}$ & $\mathbf{M}$ & & $<15$ \\
\hline & 85 & $\begin{array}{l}\text { Cretaceous- } \\
\text { Tertiary }\end{array}$ & Lignite & $1+$ & $\mathbf{N}$ & $S$ & & \\
\hline & 86 & $\begin{array}{l}\text { Cretaceous- } \\
\text { Tertiary }\end{array}$ & Lignite & $1+$ & $\mathbf{N}$ & $S$ & $<3$ & $<15$ \\
\hline & 87 & Tertiary & Lignite & Numerous & $\mathrm{N}$ & $S$ & & $<15$ \\
\hline & 89 & Tertiary & Lignite & 3 & $\mathrm{~N}$ & L & $<2$ & $<15$ \\
\hline & 90 & Tertiary & Lignite & & $\mathbf{N}$ & $S$ & & \\
\hline & 91 & Tertiary & Lignite & & $\mathbf{N}$ & $S$ & & \\
\hline \multirow[t]{6}{*}{ Colorado } & 111 & Pennsylvanian & & $1+$ & & $\mathbf{S}$ & & \\
\hline & 113 & Pennsylvanian & & $1+$ & & $\mathbf{S}$ & & \\
\hline & 116 & Pennsylvanian & & $1+$ & & $\mathbf{S}$ & & \\
\hline & 117 & Pennsylvanian & & $1+$ & & $\mathbf{S}$ & & \\
\hline & 118 & Pennsylvanian & & $1+$ & & $\mathbf{s}$ & & \\
\hline & 119 & $\begin{array}{l}\text { Cretaceous- } \\
\text { Tertiary }\end{array}$ & $\begin{array}{l}\text { Subbituminous- } \\
\text { Bituminous }\end{array}$ & 3 & & L & & \\
\hline \multirow[t]{5}{*}{ Idaho } & 134 & Tertiary & $\begin{array}{l}\text { Lignite- } \\
\text { Subbituminous }\end{array}$ & Several & $\mathbf{N}$ & $\mathbf{M}$ & $<1$ & $>15$ \\
\hline & 135 & Tertiary & Lignite & 2 & $\mathrm{~N}$ & $\mathbf{S}$ & $<2$ & $>15$ \\
\hline & 140 & Tertiary & $\begin{array}{l}\text { Lignite- } \\
\text { Subbituminous }\end{array}$ & 1 & $\mathbf{N}$ & L & $<1$ & $>15$ \\
\hline & 141 & Tertiary & Lignite & $2+$ & $\mathbf{N}$ & $S$ & & $>15$ \\
\hline & 142 & Tertiary & Lignite & 1 & $\mathrm{~N}$ & $\mathbf{S}$ & & $>15$ \\
\hline \multirow[t]{9}{*}{ Montana } & 195 & Tertiary & Lignite & & $\mathrm{N}$ & $\mathbf{M}$ & $>3$ & $<15$ \\
\hline & 196 & Tertiary & Lignite & 3 & $\mathrm{~N}$ & $S$ & $<1$ & $>15$ \\
\hline & 198 & Tertiary & Lignite & & $\mathbf{N}$ & $\mathbf{s}$ & $<1$ & $>15$ \\
\hline & 200 & Tertiary & Lignite & & $\mathbf{N}$ & $\mathbf{S}$ & $<1$ & $>15$ \\
\hline & 202 & Tertiary & Lignite & & $\mathbf{N}$ & $\mathbf{M}$ & $<1$ & $>15$ \\
\hline & 203 & Tertiary & Lignite & & $\mathrm{N}$ & $\mathbf{S}$ & $<1$ & $>15$ \\
\hline & 205 & Tertiary & Lignite & & $\mathbf{N}$ & $\mathbf{L}$ & $<1$ & $>15$ \\
\hline & 206 & Tertiary & Lignite & & $\mathrm{N}$ & $\mathbf{S}$ & $<1$ & $>15$ \\
\hline & 217 & Cretaceous & Bituminous & & $\mathbf{Y}$ & $\mathbf{s}$ & & \\
\hline
\end{tabular}


Table 14. - continued List of deposits, Coal Supplement Map, Northeast Quadrant, Circum-Pacific region

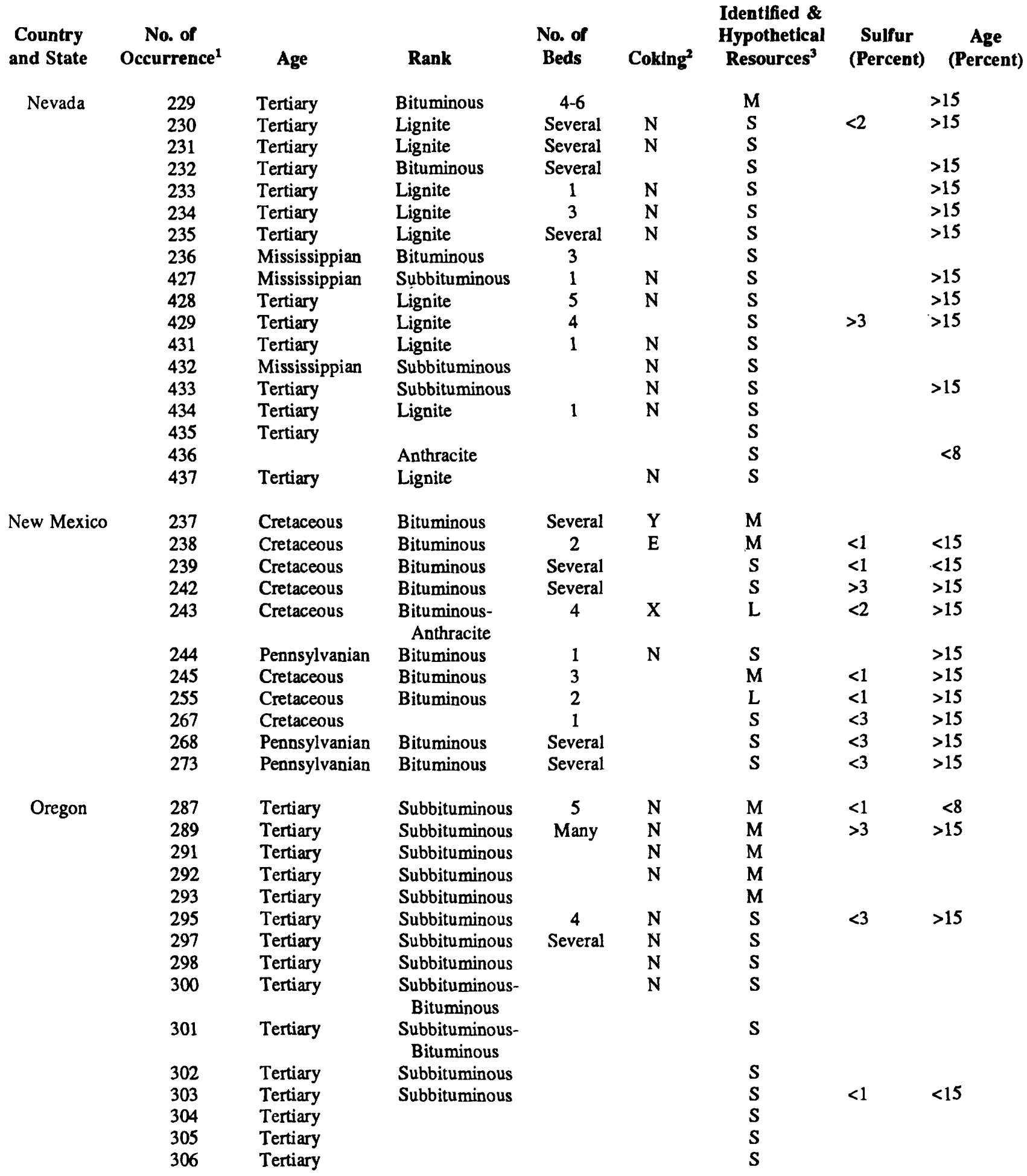


Table 14. - continued List of deposits, Coal Supplement Map, Northeast Quadrant, Circum-Pacific region

\begin{tabular}{|c|c|c|c|c|c|c|c|c|}
\hline $\begin{array}{l}\text { Country } \\
\text { and State }\end{array}$ & $\begin{array}{c}\text { No. of } \\
\text { Occurrence }\end{array}$ & Age & Rank & $\begin{array}{l}\text { No. of } \\
\text { Beds }\end{array}$ & Coking ${ }^{2}$ & $\begin{array}{l}\text { Identified \& } \\
\text { Hypothetical } \\
\text { Resources }^{3}\end{array}$ & $\begin{array}{c}\text { Sulfur } \\
\text { (Percent) }\end{array}$ & $\begin{array}{c}\text { Age } \\
\text { (Percent) }\end{array}$ \\
\hline \multirow[t]{6}{*}{ Texas } & 330 & Cretaceous & $\begin{array}{l}\text { Bituminous- } \\
\text { Anthracite }\end{array}$ & 1 & & $\mathbf{M}$ & & \\
\hline & 331 & Cretaceous & Bituminous & 2 & & L & $<1$ & $>15$ \\
\hline & 334 & Cretaceous & $\begin{array}{l}\text { Bituminous- } \\
\text { Anthracite }\end{array}$ & Several & & L & & \\
\hline & $329 a$ & Cretaceous & Bituminous & 2 & & $\mathbf{M}$ & & $>15$ \\
\hline & $329 b$ & Cretaceous & Bituminous & 2 & & $\mathbf{M}$ & & $>15$ \\
\hline & 332 & Tertiary & Lignite & Numerous & $\mathbf{N}$ & L & $>3$ & $>15$ \\
\hline \multirow[t]{4}{*}{ Utah } & 343 & $\begin{array}{l}\text { Cretaceous- } \\
\text { Tertiary }\end{array}$ & Subbituminous & 3 & $\mathbf{N}$ & L & $<2$ & $>15$ \\
\hline & 362 & Tertiary & Lignite & & $\mathbf{N}$ & $\mathbf{M}$ & & \\
\hline & 363 & Tertiary & Lignite & & $\mathrm{N}$ & $\mathbf{M}$ & & \\
\hline & 364 & Cretaceous & Lignite & & $\mathrm{N}$ & $\mathbf{M}$ & $<2$ & $<15$ \\
\hline \multirow[t]{9}{*}{ Washington } & 383 & Tertiary & Bituminous & $17+$ & $Y$ & L & $<1$ & $>15$ \\
\hline & 385 & Tertiary & $\begin{array}{l}\text { Bituminous- } \\
\text { Anthracite }\end{array}$ & $3+$ & $\mathbf{Y}$ & $\mathbf{S}$ & $<2$ & $>15$ \\
\hline & 386 & Tertiary & $\begin{array}{l}\text { Lignite- } \\
\text { Subbituminous }\end{array}$ & & $\mathbf{Y}$ & $\mathbf{M}$ & $<2$ & $>15$ \\
\hline & 388 & Tertiary & & & & M & & \\
\hline & 389 & Tertiary & & & $\mathrm{N}$ & $\mathbf{M}$ & & \\
\hline & 390 & Tertiary & Lignite & & $\mathbf{N}$ & $\mathbf{M}$ & & \\
\hline & 391 & Tertiary & Lignite & & $\mathrm{N}$ & $\mathbf{S}$ & & \\
\hline & 392 & Tertiary & Lignite & & & $\mathbf{S}$ & & \\
\hline & 394 & Tertiary & & & & $\mathbf{S}$ & & \\
\hline Alabama & 332 & Tertiary & Lignite & Numerous & $\mathrm{N}$ & L & $<3$ & $>15$ \\
\hline Louisiana & 332 & Tertiary & Lignite & Numerous & $\mathrm{N}$ & L & $<2$ & $>15$ \\
\hline Arkansas & 332 & Tertiary & Lignite & Numerous & $\mathbf{N}$ & L & $<1$ & $>15$ \\
\hline Mississippi & 332 & Tertiary & Lignite & Numerous & $\mathbf{N}$ & L & $<3$ & $>15$ \\
\hline
\end{tabular}

${ }^{1}$ See Figure 11 for location.

${ }^{2} \mathrm{E}=$ Excellent; $\quad \mathrm{G}=\mathrm{Good} ; \quad \mathrm{P}=$ Poor; $\quad=$ Unknown; $\mathrm{N}=\mathrm{No} ; \quad \mathrm{Y}=\mathrm{Yes} ; \quad \mathrm{X}=$ Partly

${ }^{3} \mathrm{~S}=<10 \times 10^{6}$ short tons; $\quad \mathrm{M}=<100 \times 10^{6}$ short tons; $\mathrm{L}=>100 \times 10^{6}$ short tons 
Table 15. List of selected deposits in the coal supplement map, Southeast Quadrant, Circum-Pacific region (refer to figures 19 and 20)

[A.S.T.M., American Society for Testing Materials; BTU, British thermal unit; -, no data]

\begin{tabular}{|c|c|c|c|c|c|c|c|c|}
\hline Country & Deposit Name & $\overline{\text { Age }}$ & $\begin{array}{l}\text { Rank of Coal } \\
\text { A.S.T.M. }\end{array}$ & $\begin{array}{l}\text { Number } \\
\text { of beds }\end{array}$ & $\begin{array}{c}\text { Calorific Value } \\
\text { (BTU//b) }\end{array}$ & Size * & $\begin{array}{l}\text { Sulphur } \\
(W t \%)\end{array}$ & $\begin{array}{c}\text { Ash } \\
(\mathrm{Wt} \%)\end{array}$ \\
\hline $\begin{array}{l}\text { gentina } \\
\text { igure 20) }\end{array}$ & $\begin{array}{l}\text { Río Tambillos } \\
\text { La Negra } \\
\text { La Delfina } \\
\text { Rickard } \\
\text { Santa Maxima/ } \\
\text { El Saltito } \\
\text { Cervantes } \\
\text { Burgos } \\
\text { J. Newbery } \\
\text { Pico Quemado } \\
\text { lndio } \\
\text { Santa Ana } \\
\text { Lepa } \\
\text { La Criolla } \\
\text { Cabo Curioso } \\
\text { Río Coyle } \\
\text { Río Santa Cruz } \\
\text { Río Turbio } \\
\text { Tierro del Fuego }\end{array}$ & $\begin{array}{c}\text { Carboniferous } \\
\text { Carboniferous } \\
\text { Carboniferous } \\
\text { Rhaetic } \\
\text { Carboniferous } \\
\text { Liassic } \\
\text { Callovian } \\
\text { Tertiary } \\
\text { Tertiary } \\
\text { Tertiary } \\
\text { Tertiary } \\
\text { Tertiary } \\
\text { Tertiary } \\
\text { Tertiary } \\
\text { Tertiary } \\
\text { Tertiary } \\
\text { Tertiary } \\
\text { Pliocene/ } \\
\text { Pleistocene } \\
\end{array}$ & $\begin{array}{c}\text { Bituminous } \\
\text { Bituminous } \\
\text { Bituminous } \\
\text { Bituminous } \\
\text { Bituminous } \\
\text { Anthracitic } \\
\text { Bituminous } \\
\text { Bituminous } \\
\text { Bituminous } \\
\text { Subbituminous } \\
\text { Subbituminous } \\
\text { Subbituminous } \\
\text { Bituminous } \\
\text { Subbituminous } \\
\text { Lignitic } \\
\text { Lignitic } \\
\text { Bituminous } \\
\text { Subbituminous } \\
\text { Peat }\end{array}$ & $\begin{array}{l}1 \\
1 \\
3 \\
6 \\
2 \\
2 \\
1 \\
2 \\
4 \\
2 \\
2 \\
2 \\
2 \\
3 \\
3 \\
- \\
5 \\
1\end{array}$ & $\begin{array}{c}10,800 \\
10,330 \\
9,800 \\
9,150 \\
7,200 \\
\\
11,500 \\
10,620 \\
12,000 \\
10,990 \\
7,300 \\
8,825 \\
10,467 \\
10,590 \\
- \\
- \\
3,600 \\
10,300 \\
6,840\end{array}$ & $\begin{array}{l}\text { Small } \\
\text { Small } \\
\text { Small } \\
\text { Small } \\
\text { Small } \\
\\
\text { Small } \\
\text { Small } \\
\text { Small } \\
\text { Small } \\
\text { Small } \\
\text { Small } \\
\text { Small } \\
\text { Small } \\
\text { Small } \\
\text { Large } \\
\text { Large } \\
\text { Large } \\
\text { Medium }\end{array}$ & $\begin{array}{c}1.4 \\
0.57 \\
1.48 \\
5.6 \\
- \\
3.0 \\
- \\
- \\
0.5 \\
0.3 \\
- \\
0.6 \\
- \\
- \\
- \\
- \\
1.0 \\
-\end{array}$ & $\begin{array}{c}26 \\
28.6 \\
28 \\
31.8 \\
45 \\
25.9 \\
20.4 \\
21.7 \\
23 \\
33.4 \\
16.6 \\
24.2 \\
17.7 \\
45 \\
- \\
- \\
0.12 \\
-\end{array}$ \\
\hline $\begin{array}{l}\text { Bolivia } \\
\text { (Figure 20) }\end{array}$ & $\begin{array}{l}\text { Beu-Buenaventura } \\
\text { Ulla-Ulia } \\
\text { Copacabana/1. Sol } \\
\text { Chacaltaya/ } \\
\text { Chuquiaguillo } \\
\text { Guaqui/Azafranal/ } \\
\text { Alchiri/Corocoro } \\
\text { Monte Blanco } \\
\text { Tacagua/El Alto } \\
\text { Apillampa/ } \\
\text { San Pedro }\end{array}$ & $\begin{array}{l}\text { Permian } \\
\text { Quaternary } \\
\text { Permian } \\
\text { Quaternary } \\
\text { Miocene } \\
\text { Quaternary } \\
\text { Permian }\end{array}$ & $\begin{array}{c}\text { Anthracitic } \\
\text { Peat } \\
\text { Anthracitic } \\
\text { Peat } \\
\text { Lignitic } \\
\text { Peat } \\
\text { Lignitic } \\
\text { Anthracitic }\end{array}$ & $\begin{array}{l}1 \\
1 \\
1 \\
1 \\
- \\
1 \\
- \\
1\end{array}$ & $\begin{array}{c}- \\
- \\
- \\
- \\
5,380 \\
- \\
5,400 \\
-\end{array}$ & \begin{tabular}{|c|}
$\begin{array}{c}\text { Small } \\
\text { Small } \\
\text { Medium } \\
\text { Small }\end{array}$ \\
Small \\
Small \\
Small \\
Small
\end{tabular} & $\begin{array}{c}1.3-4.8 \\
- \\
- \\
- \\
- \\
- \\
- \\
-\end{array}$ & $\begin{array}{c}30-50 \\
- \\
- \\
= \\
- \\
= \\
= \\
-\end{array}$ \\
\hline Bolivia & $\begin{array}{l}\text { Cochabamba/ } \\
\text { Sacaba } \\
\text { Chochoca/ } \\
\text { Totora } \\
\text { Uncio } \\
\text { Ticucha } \\
\text { Tarija/Padcaya/ } \\
\text { Tariquia }\end{array}$ & $\begin{array}{c}\text { Pliocene/ } \\
\text { Quaternary } \\
\text { Quaternary } \\
\text { Quaternary } \\
\text { Tertiary } \\
\text { Miocene/ } \\
\text { Quaternary }\end{array}$ & $\begin{array}{c}\text { Lignitic } \\
\text { Peat } \\
\text { Peat } \\
\text { Lignitic } \\
\text { Lignitic }\end{array}$ & $\begin{array}{l}- \\
1 \\
1 \\
3\end{array}$ & $\begin{array}{c}4,300 \\
- \\
- \\
- \\
7,500-11,700\end{array}$ & $\begin{array}{l}\text { Small } \\
\text { Small } \\
\text { Small } \\
\text { Small } \\
\text { Small }\end{array}$ & $\begin{array}{c}4.2 \\
- \\
- \\
- \\
1.0\end{array}$ & $\begin{array}{c}30.1 \\
- \\
- \\
7-34\end{array}$ \\
\hline $\begin{array}{l}\text { Chile } \\
\text { (Figure 20). }\end{array}$ & $\begin{array}{l}\text { Concepción } \\
\text { Lota-Schwager } \\
\text { Arauco } \\
\text { Valdivia } \\
\text { Llanguihue } \\
\text { Pto. Natales } \\
\text { Río Ruebens } \\
\text { Seno Skyring } \\
\text { 1sla Riesco } \\
\text { Pen. Brunswick }\end{array}$ & $\begin{array}{l}\text { Eocene } \\
\text { Eocene } \\
\text { Eocene } \\
\text { Miocene } \\
\text { Miocene } \\
\text { Oligocene/ } \\
\text { Miocene } \\
\text { Oligocene/ } \\
\text { Miocene } \\
\text { Oligocene/ } \\
\text { Miocene } \\
\text { Oligocene/ } \\
\text { Miocene } \\
\text { Oligocene/ } \\
\text { Miocene }\end{array}$ & $\begin{array}{c}\text { Bituminous } \\
\text { Bituminous } \\
\text { Bituminous } \\
\text { Subbituminous/ } \\
\text { Lignitic } \\
\text { Subbituminous } \\
\text { Subbituminous } \\
\text { Subbituminous } \\
\text { Subbituminous } \\
\text { Subbituminous } \\
\text { Subbituminous }\end{array}$ & $\begin{array}{l}3 \\
3 \\
3 \\
- \\
- \\
5 \\
3 \\
2 \\
3 \\
5\end{array}$ & $\begin{array}{c}13,500 \\
13,500 \\
14,000 \\
8,626 \\
8,000 \\
10,320 \\
- \\
- \\
8,750-9,940 \\
6,940-8,730\end{array}$ & $\begin{array}{c}\text { Large } \\
\text { Large } \\
\text { Large } \\
\text { Small } \\
\text { Small } \\
\text { Medium } \\
\text { Large } \\
\text { Large } \\
\text { Large } \\
\text { Large }\end{array}$ & $\begin{array}{l}2.0 \\
1.75 \\
2.5 \\
0.5 \\
0.5 \\
0.5 \\
0.6 \\
0.5 \\
0.4 \\
1.3\end{array}$ & 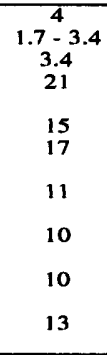 \\
\hline $\begin{array}{l}\text { Colombia } \\
\text { (Figure 19) }\end{array}$ & $\begin{array}{l}\text { El Cerrejón } \\
\text { La Jagua } \\
\text { Norte Santander } \\
\text { Cundinamarca/ } \\
\text { Boyacá } \\
\text { Alto S. Jorge } \\
\text { Antioqúa } \\
\text { Valle del Cauca }\end{array}$ & \begin{tabular}{c|} 
Paleocene \\
Paleocene/ \\
Eocene \\
Maastrichtian/ \\
Eocene \\
Maastrichtian/ \\
Paleocene \\
Oligocene \\
Oligocene/ \\
Miocene \\
Paleocene/ \\
Oligocene \\
\end{tabular} & $\begin{array}{l}\text { Bituminous } \\
\text { Bituminous } \\
\text { Bituminous } \\
\text { Bituminous } \\
\text { Bituminous } \\
\text { Bituminous } \\
\text { Anthracitic/ } \\
\text { Bituminous }\end{array}$ & $\begin{array}{c}15 \\
5 \\
4-9 \\
1-7 \\
6 \\
8 \\
7-10\end{array}$ & $\begin{array}{c}13,500 \\
11,500-13,600 \\
6,000+ \\
12,000-15,000 \\
5,100-6,300 \\
5,000-6,300 \\
11,260-15,000\end{array}$ & $\begin{array}{l}\text { Large } \\
\text { Large } \\
\text { Small } \\
\text { Large } \\
\text { Large } \\
\text { Large } \\
\text { Large }\end{array}$ & $\begin{array}{c}1.0 \\
1.0 \\
1.0 \\
1.0 \\
0.4-1.0 \\
1.0 \\
1.0-6.0\end{array}$ & $\begin{array}{l}1.7-5 \\
1-5 \\
2-7 \\
3-5 \\
1.3-6.0 \\
1.3-6.0 \\
4-24\end{array}$ \\
\hline $\begin{array}{l}\text { Costa Rica } \\
\text { (Figure 19) }\end{array}$ & $\begin{array}{l}1 \\
2 \\
3 \\
5 \\
6 \\
8 \\
9 \\
\end{array}$ & $\begin{array}{l}\text { Tertiary } \\
\text { Tertiary } \\
\text { Tertiary } \\
\text { Tertiary } \\
\text { Tertiary } \\
\text { Tertiary } \\
\text { Tertiary }\end{array}$ & $\begin{array}{c}\text { Lignitic } \\
\text { Lignitic } \\
\text { Bituminous } \\
\text { Subbituminous } \\
\text { Subbituminous } \\
\text { Subbituminous } \\
\text { Subbituminous }\end{array}$ & $\begin{array}{c}- \\
\text { Several } \\
- \\
- \\
\text { Several } \\
\text { Several } \\
\text { Several }\end{array}$ & $\begin{array}{l}- \\
- \\
- \\
- \\
-\end{array}$ & \begin{tabular}{|c|} 
Small \\
Medium \\
Small \\
Medium \\
Medium \\
Small \\
Medium \\
\end{tabular} & $\begin{array}{l}- \\
<3 \\
<2 \\
- \\
- \\
<3 \\
<3\end{array}$ & $\begin{array}{l}>15 \\
>15 \\
>15 \\
- \\
- \\
>15 \\
>15\end{array}$ \\
\hline $\begin{array}{l}\text { Ecuador } \\
\text { (Figure 19) }\end{array}$ & $\begin{array}{l}\text { Pinchincha } \\
\text { Azogues/Biblian } \\
\text { Loja } \\
\text { Malacatos } \\
\text { Napo(Oriente) }\end{array}$ & \begin{tabular}{c|} 
Quaternary \\
Maastrichtian \\
Eocene \\
Oligocene \\
Miocene \\
Neocomian \\
\end{tabular} & $\begin{array}{c}\text { Peat } \\
\text { Lignitic/ } \\
\text { Subbituminous } \\
\text { Subbituminous } \\
\text { Subbituminous } \\
\text { Lignitic }\end{array}$ & $\begin{array}{l}1 \\
5 \\
6 \\
4 \\
8\end{array}$ & $\begin{array}{c}6,000 \\
3,800-7,900 \\
7,000-9,360 \\
8,100 \\
- \\
\end{array}$ & $\begin{array}{l}\text { Small } \\
\text { Small } \\
\text { Small } \\
\text { Small } \\
\text { Small } \\
\end{array}$ & $\begin{array}{c}6.0 \\
7.0-8.0 \\
8.0 \\
\end{array}$ & $\begin{array}{c}21 \\
9-30 \\
15 \\
- \\
\end{array}$ \\
\hline $\begin{array}{l}\text { El Salvador } \\
\text { (Figure 19) }\end{array}$ & $\begin{array}{c}1 \\
2 \\
6 \\
7 \\
15\end{array}$ & $\begin{array}{l}\text { Tertiary } \\
\text { Tertiary } \\
\text { Tertiary } \\
\text { Tertiary } \\
\text { Tertiary }\end{array}$ & $\begin{array}{l}\text { Lignitic } \\
\text { Lignitic } \\
\text { Lignitic } \\
\text { Lignitic } \\
\text { Lignitic }\end{array}$ & $\begin{array}{l}- \\
- \\
-\end{array}$ & $\begin{array}{l}- \\
- \\
- \\
-\end{array}$ & $\begin{array}{l}\text { Small } \\
\text { Small } \\
\text { Small } \\
\text { Small } \\
\text { Small }\end{array}$ & $\begin{array}{l}\overline{-} \\
- \\
- \\
-\end{array}$ & $\begin{array}{c}>15 \\
= \\
= \\
>15\end{array}$ \\
\hline $\begin{array}{l}\text { Guatemala } \\
\text { (Figure 19) }\end{array}$ & $\begin{array}{l}1 \\
2 \\
4 \\
5 \\
6 \\
8 \\
14 \\
18 \\
19 \\
22\end{array}$ & $\begin{array}{l}\text { Tertiary } \\
\text { Tertiary } \\
\text { Tertiary } \\
\text { Tertiary } \\
\text { Tertiary } \\
\text { Tertiary } \\
\text { Tertiary } \\
\text { Tertiary } \\
\text { Tertiary } \\
\text { Tertiary }\end{array}$ & $\begin{array}{l}\text { Lignitic } \\
\text { Lignitic } \\
\text { Lignitic } \\
\text { Lignitic } \\
\text { Lignitic } \\
\text { Lignitic } \\
\text { Lignitic } \\
\text { Lignitic } \\
\text { Lignitic } \\
\text { Lignitic }\end{array}$ & $\begin{array}{l}\bar{z} \\
\overline{-} \\
- \\
- \\
\overline{-} \\
\overline{-} \\
- \\
-\end{array}$ & $\begin{array}{l}\overline{-} \\
- \\
- \\
- \\
- \\
- \\
-\end{array}$ & $\begin{array}{l}\text { Small } \\
\text { Small } \\
\text { Small } \\
\text { Small } \\
\text { Small } \\
\text { Small } \\
\text { Small } \\
\text { Small } \\
\text { Small } \\
\text { Small }\end{array}$ & $\begin{array}{c}<3 \\
- \\
- \\
>3 \\
<3 \\
- \\
- \\
- \\
- \\
-\end{array}$ & $\begin{array}{l}>15 \\
- \\
>15 \\
>15 \\
= \\
= \\
>8 \\
-\end{array}$ \\
\hline
\end{tabular}


Table 15.-contimued

[A.S.T.M., American Society for Testing Materials; BTU, British thermal unit; -, no data]

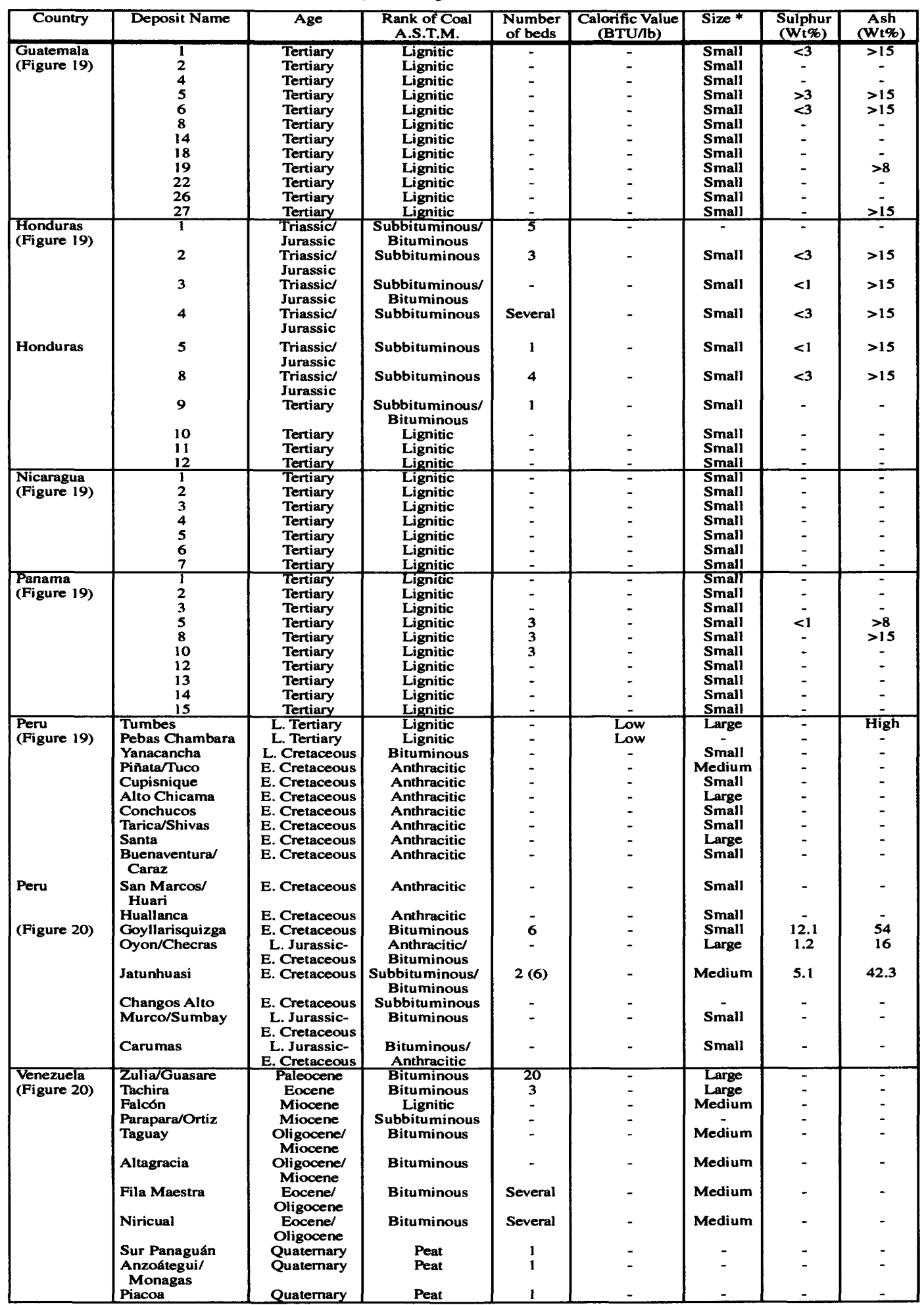

*Small: less than $10 \times 10^{6}$ metric tons; medium: less than $100 \times 10^{6}$ metric tons; large: more than $100 \times 10^{6}$ metric tons. 
Table 16. General characteristics of selected major coal fields, Northwest Quadrant, Circum-Pacific region (numbers refer to figure 21)

\begin{tabular}{|c|c|c|c|c|c|c|c|c|}
\hline $\begin{array}{c}\text { Country } \\
\text { Field number }\end{array}$ & Field name & Age & Rank & $\begin{array}{l}\text { Number } \\
\text { of beds }\end{array}$ & Coking 1 & $\begin{array}{l}\text { Hypothetical } \\
\text { resources }^{2}\end{array}$ & Sulfur(\%) & Ash(\%) \\
\hline \multicolumn{9}{|l|}{ Russia } \\
\hline 1 & Kempendgeisk & $\begin{array}{l}\text { Jurassic- } \\
\text { Cretaceous }\end{array}$ & Subbituminous & 1 & $\mathbf{N}$ & $\mathbf{M}$ & $<1$ & $<9$ \\
\hline 2 & Spoln & Jurassic & Bituminous & 1 & $\mathbf{N}$ & $\mathbf{M}$ & - & $>5$ \\
\hline 3 & Kilofsk & Cretaceous & - & - & $\mathbf{N}$ & L & $<1$ & $<12$ \\
\hline 4 & Mamontofsk & Cretaceous & - & - & - & $\mathbf{M}$ & $<1$ & $>11$ \\
\hline 5 & Kirdgemsk & Jurassic & Bituminous & 11 & $\mathbf{N}$ & L & $<1$ & $<20$ \\
\hline 6 & Kangarask & Cretaceous & Bituminous & 10 & $\mathbf{N}$ & $\mathrm{L}$ & $<2$ & $<32$ \\
\hline 7 & Harabarahsk & Jurassic & Bituminous & - & - & $\mathbf{M}$ & $<1$ & $<11$ \\
\hline 8 & Nadeginsk & Jurassic & Bituminous & 4 & - & $\mathbf{M}$ & $<1$ & $<19$ \\
\hline 9 & Soginsk & 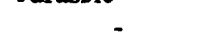 & Bituminous & 2 & - & $\mathbf{M}$ & $<1$ & $<8$ \\
\hline 10 & Kyralsk & 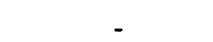 & Bituminous & 3 & - & $\mathbf{M}$ & $<1$ & $>12$ \\
\hline 11 & Dalpilsk & Cretaceous & Bituminous & Numerous & - & $\mathrm{L}$ & $<1$ & $<14$ \\
\hline 12 & Velhunealkaganinsk & Cretaceous & Bituminous & 2 & - & $\mathrm{L}$ & $<1$ & $<10$ \\
\hline 13 & Nidgnealkagarinsk & - & Bituminous & Numerous & - & $\mathrm{L}$ & $<1$ & $>9$ \\
\hline 14 & Kenofsk & Cretaceous & Bituminous & 3 & - & $\mathbf{M}$ & $<1$ & $<10$ \\
\hline 15 & Garimofsk & Cretaceous & Subbituminous & 12 & - & $\mathbf{M}$ & $<1$ & $<14$ \\
\hline 16 & Ergensk & ה & $\begin{array}{l}\text { Subbituminous- } \\
\text { bituminous }\end{array}$ & Numerous & - & $\mathbf{M}$ & $<2$ & $<10$ \\
\hline 17 & Klasnoletchensk & Cretaceous & Bituminous & Numerous & - & $\mathbf{M}$ & $<1$ & $<10$ \\
\hline 18 & Elogion & Cretaceous & Bituminous & Numerous & - & $\mathbf{M}$ & $<1$ & $<5$ \\
\hline 19 & Biolkemyusk & Cretaceous & Bituminous & Numerous & - & $\mathbf{M}$ & $<1$ & $<5$ \\
\hline 20 & Darn & Triassic & Bituminous & 3 & - & $\mathbf{M}$ & $<2$ & $>13$ \\
\hline 21 & Kyhtyisk & Tertiary & Bituminous & Numerous & - & $\mathrm{s}$ & $<1$ & $>13$ \\
\hline 22 & Kovensk & Tertiary & $\begin{array}{l}\text { Subbituminous- } \\
\text { bituminous }\end{array}$ & Numerous & - & & $<1$ & $<4$ \\
\hline 23 & Rankofsk & Tertiary & Bituminous & Numerous & - & L & $<1$ & 10 \\
\hline 24 & Merkovodnensk & & Subbituminous & Several & - & $\mathrm{L}$ & $<1$ & $>20$ \\
\hline 25 & Erigenyilsk & Tertiary & Bituminous & 2 & - & $S$ & $<4$ & $<4$ \\
\hline 26 & Anadyilsk & Tertiary & Bituminous & Numerous & - & $\mathbf{M}$ & - & $<18$ \\
\hline \multicolumn{9}{|l|}{ Japan } \\
\hline 27 & Kushiro & Tertiary & Subbituminous & Numerous & $\mathbf{N}$ & L & $<1$ & $<10$ \\
\hline 28 & Tempoku & Tertiary & Subbituminous & Numerous & $\mathrm{N}$ & $\mathbf{M}$ & $<1$ & $<10$ \\
\hline 29 & Rumoi & Tertiary & $\begin{array}{l}\text { Subbituminous- } \\
\text { bituminous }\end{array}$ & Numerous & N.Y & $\mathbf{M}$ & S & $<10$ \\
\hline 30 & Kabato & Tertiary & Bituminous & Numerous & $\mathbf{N}$ & $s$ & - & $<5$ \\
\hline 31 & Ishikari & Tertiary & Bituminous & Numerous & E & L & $<1$ & $<20$ \\
\hline 32 & Mogami & Tertiary & Lignite & Numerous & $\mathbf{N}$ & $\mathbf{M}$ & & $<10$ \\
\hline 33 & Nishitagawa & Tertiary & Subbituminous- & Numerous & $\mathbf{Y}$ & $S$ & $<1$ & $>10$ \\
\hline 34 & Johban & Tertiary & $\begin{array}{l}\text { Subbituminous- } \\
\text { bituminous }\end{array}$ & Numerous & $\mathbf{N}$ & L & $<6$ & $>10$ \\
\hline 35 & Kumano & Tertiary & Anthracite & 2 & $\mathbf{N}$ & $s$ & $<3$ & $>10$ \\
\hline 36 & Omine \&Ube & Triassic- & Bituminous- & Numerous & N & L & - & $<30$ \\
\hline 37 & Chikuho & Tertiary & Bituminous & Numerous & N-Y & L & $<1$ & $>10$ \\
\hline 38 & Miike & Tertiary & Bituminous & Numerous & E & L & & - \\
\hline 39 & Ikeshima & Tertiary & Bituminous & 3 & G & $\mathrm{L}$ & . & $<10$ \\
\hline 40 & Takashima & Tertiary & Bituminous & Numerous & $\mathbf{E}$ & $\overrightarrow{\mathrm{L}}$ & $<1$ & $>10$ \\
\hline \multirow{2}{*}{\multicolumn{9}{|c|}{ Korea }} \\
\hline & & & & & & & & \\
\hline$\Delta 2$ & Sanchok & $\begin{array}{l}\text { Carboniferous- } \\
\text { Permian }\end{array}$ & Anthracite & Numerous & $\mathbf{N}$ & $\mathbf{M}$ & $<1$ & $<20$ \\
\hline 43 & Mungyong-Eunsong & Permian & Anthracite & - & $\mathbf{N}$ & $\mathbf{S}$ & - & \\
\hline 44 & Hwasan & $\begin{array}{l}\text { Permian- } \\
\text { Jurassic }\end{array}$ & Anthracite & - & $\mathbf{N}$ & $\mathbf{M}$ & - & $<20$ \\
\hline 45 & Chung Nam & Jurassic & Anthracite & Numerous & $\mathbf{N}$ & $\mathbf{M}$ & - & - \\
\hline 46 & Ham Beak & Permian & Anthracite & - & $\mathbf{N}$ & $\mathbf{M}$ & - & $>50$ \\
\hline \multirow{2}{*}{\multicolumn{9}{|c|}{ China }} \\
\hline & & & & & & & & \\
\hline $\begin{array}{l}48 \\
49\end{array}$ & $\begin{array}{l}\text { Hegang } \\
\text { Shuang-va-shan }\end{array}$ & $\begin{array}{l}\text { Jurassic } \\
\text { Jurassic }\end{array}$ & Bituminous & 10 & $\underset{N}{\mathbf{N}-P}$ & L & $<1$ & $\begin{array}{l}>12 \\
>12\end{array}$ \\
\hline
\end{tabular}


Table 16. - continued General characteristics of selected major coal fields, Northwest Quadrant, Circum-Pacific region (numbers refer to figure 21)

\begin{tabular}{|c|c|c|c|c|c|c|c|c|}
\hline $\begin{array}{c}\text { Country } \\
\text { Field number }\end{array}$ & Field name & Age & Rank & $\begin{array}{l}\text { Number } \\
\text { of beds }\end{array}$ & Coking 1 & $\begin{array}{l}\text { Hypothetical } \\
\text { resources }^{2}\end{array}$ & Sulfur(\%) & $\operatorname{Ash}(\%)$ \\
\hline 50 & Fuxun & Tertiary & $\begin{array}{l}\text { Subbituminous- } \\
\text { bituminous }\end{array}$ & Numerous & $\overline{\mathbf{N}-\mathbf{P}}$ & $\mathrm{L}$ & $<1$ & $>12$ \\
\hline 51 & Benxi & $\begin{array}{l}\text { Permian- } \\
\text { Carboniferous }\end{array}$ & $\begin{array}{l}\text { Bituminous- } \\
\text { semianthracite }\end{array}$ & Numerous & $\mathbf{E}$ & L & $<2$ & $<10$ \\
\hline 52 & Liaoyang & Jurassic & Bituminous & 4 & - & L & $<1$ & $<5$ \\
\hline 53 & Fuxin & Jurassic & Bituminous & Numerous & - & $\mathrm{L}$ & - & $<8$ \\
\hline 54 & Beipiao & Jurassic & Bituminous & 6 & - & $\mathbf{L}$ & - & $<11$ \\
\hline 55 & Kailuan & $\begin{array}{l}\text { Permian- } \\
\text { Carboniferous }\end{array}$ & Bituminous & Numerous & $\mathbf{E}$ & L & $<2$ & $<18$ \\
\hline 56 & Jingxi & Carboniferous & Anthracite & 4 & $\mathbf{N}$ & L & $<1$ & $<20$ \\
\hline 57 & Datong & $\begin{array}{l}\text { Carboniferous- } \\
\text { Jurassic }\end{array}$ & Bituminous & 6 & P-G & - & $\mathrm{L}$ & $<1$ \\
\hline 58 & $\begin{array}{l}\text { Yangchuang- } \\
\text { Jingxing }\end{array}$ & $\begin{array}{l}\text { Carboniferous- } \\
\text { Permian }\end{array}$ & Bituminous & Several & $\mathbf{G}$ & L & $<6$ & $<20$ \\
\hline 59 & Taiyuan & $\begin{array}{l}\text { Carboniferous- } \\
\text { Permian }\end{array}$ & $\begin{array}{l}\text { Bituminous- } \\
\text { semianthracite }\end{array}$ & 5 & N-P & L & $<8$ & $<14$ \\
\hline 60 & Xuangang-chen & $\begin{array}{l}\text { Carboniferous- } \\
\text { Permian }\end{array}$ & Bituminous & 5 & - & $\mathrm{L}$ & $<6$ & $<7$ \\
\hline 61 & Fujia-tan & $\begin{array}{l}\text { Carboniferous- } \\
\text { Permian }\end{array}$ & Bituminous & Numerous & $\mathbf{E}$ & $\mathbf{M}$ & $<2$ & $<7$ \\
\hline 62 & Fengfeng & $\begin{array}{l}\text { Carboniferous- } \\
\text { Permian }\end{array}$ & Bituminous & Numerous & $\mathbf{E}$ & L & - & - \\
\hline 63 & Jiaozuo & $\begin{array}{l}\text { Carboniferous- } \\
\text { Permian }\end{array}$ & Anthracite & 1 & $\mathbf{N}$ & L & $<1$ & $<8$ \\
\hline 64 & Pingting-shan & $\begin{array}{l}\text { Carboniferous- } \\
\text { Permian }\end{array}$ & Bituminous & Numerous & $\mathbf{E}$ & $\mathbf{M}$ & - & - \\
\hline 65 & Xintai & - & Bituminous & 19 & $\mathrm{E}$ & M & $<1$ & $<12$ \\
\hline 66 & Zipo & $\begin{array}{l}\text { Carboniferous- } \\
\text { Permian }\end{array}$ & Bituminous & Numerous & $\mathbf{N}$ & $\mathbf{M}$ & $<4$ & $<25$ \\
\hline 67 & Huaibei & $\begin{array}{l}\text { Carboniferous- } \\
\text { Permian }\end{array}$ & Anthracite & 3 & $\mathbf{N}$ & L & - & $>5$ \\
\hline 68 & Suchou-Huainan & $\begin{array}{l}\text { Carboniferous- } \\
\text { Permian }\end{array}$ & Bituminous & Numerous & - & L & - & $<13$ \\
\hline 69 & Huangshi & Jurassic & Anthracite & 2 & $\mathbf{N}$ & $\mathbf{M}$ & $<3$ & $<16$ \\
\hline 70 & Fengcheng & Permian & - & 2 & - & $\mathbf{L}$ & - & 13 \\
\hline 71 & Pingxiang & Carboniferous & Bituminous & - & - & $\bar{L}$ & $<1$ & 17 \\
\hline 72 & Xiangtan & Jurassic & Bituminous & 2 & - & $\mathbf{M}$ & 2 & 7 \\
\hline 73 & Zixing & Permian & Anthracite & 4 & $\mathbf{N}$ & L & - & - \\
\hline 74 & Qujiang & Permian & Semi-anthracite & Several & $\mathbf{N}$ & $\mathbf{L}$ & $<1$ & $<13$ \\
\hline 75 & Mei-xian & Paleozoic & & 5 & - & - & $<2$ & 20 \\
\hline 76 & Zhangping-Longyan & Carboniferous & Anthracite & 2 & $\mathbf{N}$ & L & - & 16 \\
\hline 77 & Shaowu & Carboniferous & Anthracite & & $\mathbf{N}$ & - & 2 & 4 \\
\hline 78 & Chongan-Jianou & Mesozoic & Bituminous & 3 & Y & - & - & 22 \\
\hline 79 & Guiyang & Permian & Bituminous & Several & $\mathrm{Y}$ & $\mathbf{M}$ & - & $<7$ \\
\hline 80 & Anshun-Liuzhi & Permian & Bituminous & 6 & - & $\mathbf{M}$ & - & 19 \\
\hline 81 & Shuicheng-Panxian & Permian & Bituminous & - & $\mathbf{Y}$ & $\mathbf{M}$ & $<1$ & 10 \\
\hline 82 & Xuanliang-Pinglang & Permian & Bituminous & - & - & $\mathbf{M}$ & - & - \\
\hline $\begin{array}{c}83 \\
\text { Taiwan }\end{array}$ & Baotou & Jurassic & Bituminous & 25 & P-G & $\mathbf{M}$ & $<1$ & $<5$ \\
\hline 84 & Chilung & Tertiary & $\begin{array}{l}\text { Subbituminous- } \\
\text { bituminous }\end{array}$ & - & - & L & $<3$ & $<10$ \\
\hline 85 & Taipei & Tertiary & $\begin{array}{l}\text { Subbituminous- } \\
\text { bituminous }\end{array}$ & - & - & $\mathbf{M}$ & $<3$ & $<10$ \\
\hline $\begin{array}{c}86 \\
\text { Philippines }\end{array}$ & Hsinchu-Nangchung & Tertiary & Subbituminous & - & - & $\mathbf{M}$ & $<2$ & $<10$ \\
\hline 87 & Polillo & Tertiary & Bituminous & 4 & $\mathbf{Y}$ & $\mathbf{S}$ & $<1$ & $<4$ \\
\hline 88 & Panganiban & Tertiary & $\begin{array}{l}\text { Bituminous- } \\
\text { semianthracite }\end{array}$ & 4 & $\mathbf{Y}$ & S & $<1$ & 16 \\
\hline 89 & Liguan & Tertiany & Subbituminous & 2 & $\mathbf{N}$ & $\mathbf{S}$ & $<1$ & 5 \\
\hline 90 & $\begin{array}{l}\text { Calanga \& Eastem } \\
\text { Batan }\end{array}$ & Tertiary & Subbituminous & 2 & $\mathbf{N}$ & $\mathbf{S}$ & $<3$ & 6 \\
\hline 91 & Gatbo & Tertiary & Subbituminous & 1 & $\mathbf{N}$ & $\mathbf{S}$ & $<2$ & 4 \\
\hline
\end{tabular}


Table 16. -continued General characteristics of selected major coal fields, Northwest Quadrant, Circum-Pacific region (numbers refer to figure 21)

\begin{tabular}{|c|c|c|c|c|c|c|c|c|}
\hline $\begin{array}{l}\text { Country } \\
\text { Field number }\end{array}$ & Field name & Age & $\overline{\text { Rank }}$ & $\begin{array}{l}\text { Number } \\
\text { of beds }\end{array}$ & Coking 1 & $\begin{array}{l}\text { Hypothetical } \\
\text { resources }^{2}\end{array}$ & Sulfur(\%) & Ash(\%) \\
\hline 92 & Bulalacao & Tertiary & Subbituminous & Several & $\bar{N}$ & $\mathbf{S}$ & 5 & $<4$ \\
\hline 93 & Semirara & Tertiary & Subbituminous & Numerous & $\mathbf{N}$ & $\mathbf{S}$ & $<1$ & $<4$ \\
\hline 94 & Cajumayjumayan & Tertiary & Subbituminous & Numerous & $\mathrm{N}$ & - & - & - \\
\hline 95 & Escalante & Tertiary & $\begin{array}{l}\text { Subbituminous- } \\
\text { bituminous }\end{array}$ & 4 & $\mathbf{Y}$ & $\mathbf{s}$ & $<5$ & $5-7$ \\
\hline 96 & Camansi-Licos & Tertiary & Subbituminous & Several & $\mathbf{N}$ & $\mathbf{s}$ & $<1$ & $<10$ \\
\hline 97 & Toledo-Uling & Tertiary & $\begin{array}{l}\text { Subbituminous- } \\
\text { bituminous }\end{array}$ & Several & N-P & $\bar{S}$ & $<5$ & $<10$ \\
\hline 98 & $\begin{array}{l}\text { Argo-Dalagnete } \\
\text { Mantalongon }\end{array}$ & Tertiary & $\begin{array}{l}\text { Subbituminous- } \\
\text { bituminous }\end{array}$ & Several & N-P & $\mathbf{s}$ & $<1$ & $<10$ \\
\hline 99 & Lingig-Bislig & Tertiary & $\begin{array}{l}\text { Bituminous- } \\
\text { subbituminous }\end{array}$ & Numerous & N-P & $\mathbf{S}$ & $<1$ & $<14$ \\
\hline $\begin{array}{c}100 \\
\text { Vietnam }\end{array}$ & Lalat-Lumbang & Tertiary & Bituminous & Numerous & - & $\mathbf{s}$ & - & $<6$ \\
\hline 101 & Nong Son & Triassic & Bituminous & - & - & $\mathbf{S}$ & $<2$ & $<10$ \\
\hline 102 & Phan Me & Triassic & Bituminous & Numerous & $\mathbf{N}$ & - & 1 & $<18$ \\
\hline & Bo $\mathrm{Ha}$ & Triassic & Anthracite & Numerous & $\mathbf{N}$ & $=$ & - & - \\
\hline \multicolumn{9}{|c|}{ Myanmar } \\
\hline 104 & Qung Yen & Triassic & Anthracite & - & $\mathbf{N}$ & L & $<1$ & $<7$ \\
\hline 105 & Lo-an & Cretaceous & Bituminous & - & $\mathbf{Y}$ & $\mathbf{S}$ & - & $<12$ \\
\hline 106 & Panlaung & Cretaceous & Bituminous & - & - & - & - & 13 \\
\hline 107 & Hlemauk-Kywezim & Cretaceous & Bituminous & - & - & - & - & $<7$ \\
\hline 108 & Kalewa & Tertiary & Lignite & 3 & $\mathbf{N}$ & - & $<1$ & $<3$ \\
\hline 109 & Kyobin & Tertiary & Lignite & - & - & - & - & 7 \\
\hline \multirow{2}{*}{\multicolumn{9}{|c|}{ Thailand }} \\
\hline & & & & & & & & \\
\hline 111 & Mae Mo & Tertiary & Lignite & 2 & $\mathbf{N}$ & $\mathbf{M}$ & 3 & 16 \\
\hline 112 & $\mathrm{Li}$ & Tertiary & Subbituminous & 2 & $\mathbf{N}$ & $\mathbf{M}$ & $<2$ & 11 \\
\hline \multirow{2}{*}{\multicolumn{9}{|c|}{ Malaysia }} \\
\hline & & & & & & & & \\
\hline 114 & Batu Anang & Tertiary & Subbituminous & 2 & $\mathbf{N}$ & $\mathbf{S}$ & $<0.5$ & 9 \\
\hline 115 & Enggor & Tertiary & Subbituminous & 1 & $\mathrm{~N}$ & S & - & 9 \\
\hline 116 & Silantek & Tertiary & Anthracite & Numerous & $\mathbf{N}$ & $\mathbf{S}$ & $<0.9$ & 11 \\
\hline 117 & Merit-Pila & Tertiary & Subbituminous & Numerous & $\mathbf{N}$ & $M$ & $<0.1$ & 1 \\
\hline 118 & Bintula & Tertiary & Bituminous & 2 & - & $\mathbf{M}$ & $<3$ & $<7$ \\
\hline 119 & Labuan & Tertiary & Subbituminous & 4 & $\mathbf{N}$ & $\mathbf{S}$ & $<2$ & $<6$ \\
\hline \multicolumn{9}{|l|}{$\begin{array}{c}120 \\
\text { Indonesia }\end{array}$} \\
\hline $\begin{array}{c}\text { maonesla } \\
121\end{array}$ & Onbilin & Tertiary & Bituminous & 7 & $\mathbf{Y}$ & $\mathrm{L}$ & $<1$ & $1-2$ \\
\hline 122 & Bukit Asam & Tertiary & $\begin{array}{l}\text { Lignite- } \\
\text { bituminous }\end{array}$ & $6-7$ & N-P & $\mathbf{M}$ & 61 & $<1.5$ \\
\hline 123 & Berau & Tertiary & Bituminous & 4 & $\mathbf{P}$ & $\mathbf{M}$ & $<1$ & 3 \\
\hline 124 & Kaltin Prima & Tertiary & Bituminous & 4 & $\mathbf{P}$ & $\mathbf{s}$ & $<1$ & 1 \\
\hline 125 & Kideco Jaya Agung & Tertiary & Subbituminous & Numerous & $\mathbf{N}$ & $\mathbf{M}$ & $<1$ & 2 \\
\hline 126 & Utah & Tertiary & Bituminous & 3 & N-P & M & 3 & 20 \\
\hline
\end{tabular}

1Coking: E, excellent; G, good; $P$, poor; -, unknown; $N$, no; $Y$, yes.

${ }^{2}$ Hypothetical resources: $S=<10 \times 10^{6}$ short tons; $M=<100 \times 10^{6}$ short tons; $L=>100 \times 10^{6}$ short tons. 
Table 17. Coal fields, Southwest Quadrant, Circum-Pacific region

\begin{tabular}{|c|c|c|c|c|}
\hline Country & Field & Age & Rank & Resour \\
\hline \multicolumn{5}{|l|}{ Australia } \\
\hline \multirow[t]{5}{*}{ New South Wales } & Sydney/Gunnedah & Permian & Bituminous & $\mathrm{L}$ \\
\hline & Ashford & Permian & Bituminous & $S$ \\
\hline & Gloucester & Permian & Bituminous & $\mathbf{M}$ \\
\hline & Lorne & Triassic & Subbituminous & $S$ \\
\hline & Nymboida & Triassic & Bituminous & $S$ \\
\hline $\begin{array}{c}\text { New South Wales/ } \\
\text { Queensland }\end{array}$ & Clarence/Moreton & Jurassic & Bituminous & $\mathrm{L}$ \\
\hline \multirow[t]{20}{*}{ Queensland } & Bowen & Permian & Bituminous & $\mathrm{L}$ \\
\hline & Blair Athol & Permian & Bituminous & $\mathrm{L}$ \\
\hline & Calen & Permian & Bituminous & $\mathrm{S}$ \\
\hline & Galilee & Permian & Subbituminous & $\mathrm{L}$ \\
\hline & Little River/Oakey & Permian & Subbituminous & $S$ \\
\hline & Mount Mulligan & Permian & Bituminous & $S$ \\
\hline & Oaklands/Coorabin & Permian & Subbituminous & $\mathrm{L}$ \\
\hline & Olive River & Permian & Bituminous & $S$ \\
\hline & Wolfang & Permian & Bituminous & $\mathrm{L}$ \\
\hline & Callide & Triassic & Subbituminous & $\mathrm{L}$ \\
\hline & Ipswich & Triassic & Bituminous & $\mathrm{L}$ \\
\hline & Tarong & Triassic & Subbituminous & $\mathrm{L}$ \\
\hline & Eromanga & $\begin{array}{c}\text { Jurassic/Cretaceo } \\
\text { us }\end{array}$ & $\begin{array}{c}\text { Lignite/ } \\
\text { Subbituminous }\end{array}$ & L? \\
\hline & Laura & Jurassic & Bituminous & S? \\
\hline & Maryborough & Cretaceous & Bituminous & $\mathrm{S}$ \\
\hline & Mulgildie & Jurassic & Subbituminous & $\mathbf{M}$ \\
\hline & Styx & Cretaceous & Bituminous & $S$ \\
\hline & Surat & Jurassic & Bituminous & $\mathrm{L}$ \\
\hline & Tiaro & Jurassic & Bituminous & $S$ \\
\hline & Waterpark Creek & Tertiary & Lignite & S? \\
\hline $\begin{array}{l}\text { Queensland/South } \\
\text { Australia }\end{array}$ & Cooper & Permian & Bituminous & L \\
\hline \multirow[t]{4}{*}{ South Australia } & Arckaringa & Permian & Subbituminous & $\mathrm{L}$ \\
\hline & Leigh Creek & Triassic & Subbituminous & $\mathrm{L}$ \\
\hline & Polda & Jurassic & Subbituminous & $\mathrm{L}$ \\
\hline & South Aust misc. & Tertiary & Lignite & $\mathrm{L}$ \\
\hline $\begin{array}{l}\text { South Australia/ } \\
\text { Northern Territory }\end{array}$ & Pedirka & Permian & Bituminous & $?$ \\
\hline $\begin{array}{l}\text { Northern Territory/ } \\
\text { Western Australia }\end{array}$ & Bonaparte & Permian & Subbituminous & $?$ \\
\hline \multirow[t]{5}{*}{ Western Australia } & Canning & Permian & $\begin{array}{c}\text { Subbituminous/ } \\
\text { Bituminous }\end{array}$ & $?$ \\
\hline & Collie/Wilga & Permian & Subbituminous & $\mathrm{L}$ \\
\hline & Carnarvon & Triassic & Subbituminous & $?$ \\
\hline & Perth & Jurassic & Subbituminous & $\mathbf{M}$ \\
\hline & Bremer & Tertiary & Lignite & $\mathbf{S}$ \\
\hline Tasmania & Tasrnania & Permian/Triassic & $\begin{array}{c}\text { Anthracite/ } \\
\text { Subbituminous/ } \\
\text { Cannel }\end{array}$ & $\mathrm{L}$ \\
\hline \multirow[t]{5}{*}{ Victoria } & Gippsland & Cretaceous & Bituminous & $S$ \\
\hline & Anglesea & Tertiary & Lignite & $\mathrm{L}$ \\
\hline & Otway & Tertiary & Lignite & $\mathrm{L}$ \\
\hline & Gelliondale & Tertiary & Lignite & $\mathrm{L}$ \\
\hline & Stradbroke & Tertiary & Lignite & $\mathrm{L}$ \\
\hline
\end{tabular}


Table 17.-continued Coal fields, Southwest Quadrant, Circum-Pacific region

\begin{tabular}{|c|c|c|c|c|}
\hline Country & Field & Age & Rank & Resources \\
\hline \multicolumn{5}{|l|}{ New Zealand } \\
\hline \multirow[t]{3}{*}{ North Island } & Northland & Tertiary & Subbituminous & $S$ \\
\hline & Waikato & Tertiary & Subbituminous & $\mathrm{L}$ \\
\hline & Taranaki & Tertiary & Subbituminous & L \\
\hline \multirow[t]{4}{*}{ South Island } & Nelson-Westland & Cretaceous/Tertia & Bituminous/ & $\mathbf{L}$ \\
\hline & Canterbury & $\begin{array}{c}\text { Cretaceous/Tertia } \\
\text { ry }\end{array}$ & Subbituminous & $\mathbf{M}$ \\
\hline & Otago & $\begin{array}{c}\text { Cretaceous/Tertia } \\
\text { ry }\end{array}$ & $\begin{array}{c}\text { Lignite/ } \\
\text { Subbituminous }\end{array}$ & $\mathbf{L}$ \\
\hline & Southland & $\begin{array}{l}\text { Cretaceous/Tertia } \\
\text { ry }\end{array}$ & $\begin{array}{c}\text { Lignite/ } \\
\text { Subbituminous }\end{array}$ & $\mathbf{L}$ \\
\hline \multirow{2}{*}{ New Caledonia } & Nondoue & Cretaceous & Bituminous? & $S$ \\
\hline & Moindou & Cretaceous & Bituminous & $S$ \\
\hline
\end{tabular}

Table 18. Australian oil shale deposits, Southwest Quadrant, Circum-Pacific region

\begin{tabular}{|c|c|c|c|c|}
\hline State & Deposit & Age & $\begin{array}{l}\text { Shale resources } \\
\text { (Mt) }\end{array}$ & $\begin{array}{l}\text { Recoverable oil } \\
\text { (millions of } \\
\text { cubic meters) }\end{array}$ \\
\hline \multirow[t]{10}{*}{ Queensland } & Alpha & Permian & 5.3 & 1.3 \\
\hline & Condor & Tertiary & 17,849 & 994 \\
\hline & Duaringa & Tertiary & $?$ & 477 \\
\hline & Julia Creek & Cretaceous & 4,000 & 238 \\
\hline & Lowmead & Tertiary & $?$ & $?$ \\
\hline & Nagoorin/Littlemore & Tertiary & $?$ & $?$ \\
\hline & Rundle & Tertiary & 4,678 & 361 \\
\hline & Stuart & Tertiary & 5,000 & 318 \\
\hline & Toolebuc Formation & Cretaceous & $3,838,000$ & 230,000 \\
\hline & Yaamba & Tertiary & $?$ & 267 \\
\hline \multirow[t]{2}{*}{ New South Wales } & Baerami & Permian & 16 & 4 \\
\hline & Newnes/Glen Davis & Permian & 20 & 9 \\
\hline Tasmania & $\begin{array}{l}\text { Northern Tasmanian } \\
\text { deposits }\end{array}$ & Permian & 31 & 4 \\
\hline
\end{tabular}

Table 19. New Zealand oil shale deposits, Southwest Quadrant, Circum-Pacific region

\begin{tabular}{cllcc}
\hline Location & Deposit & Age & $\begin{array}{c}\text { Shale } \\
\text { resources (Mt) }\end{array}$ & $\begin{array}{c}\text { Recoverable oil } \\
\text { (million } \\
\text { liters/mt) }\end{array}$ \\
\hline \multirow{3}{*}{ South Island } & Cambrian & Tertiary & 0.5 & 128 \\
& Freshford & Tertiary & 0.075 & 144 \\
& Idaburn & Tertiary & $?$ & $?$ \\
& Nevis & Tertiary & 8 & 117 \\
& Orepuki & Tertiary & 7 & 190 \\
& Waitati & Tertiary & 1.5 & 88 \\
\hline
\end{tabular}


Table 20. Major geothermal sites by country, Southeast Quadrant, Circum-Pacific region (refer to figures 22 and 23)

\begin{tabular}{|c|c|c|c|}
\hline Country & Locality & $\begin{array}{c}\text { Temperature } \\
\left(\mathbf{C}^{\circ}\right)\end{array}$ & Type \\
\hline $\begin{array}{l}\text { Argentina } \\
\text { (Figure 23) }\end{array}$ & $\begin{array}{l}\text { Tuzgle Volcano (geothermal project) } \\
\text { Tocomar } \\
\text { Baños de Pompeya (resort) } \\
\text { Socompa Volcano } \\
\text { Termas de Reyes (resort) } \\
\text { Agua Caliente } \\
\text { Santa Bábara (El Ramal) } \\
\text { Rosario de la Frontera (resort) } \\
\text { Ceibal (Candelaria) } \\
\text { Villavil (resort) } \\
\text { Rio Hondo (geothermal project and resort) } \\
\text { Fiambala } \\
\text { Rio Blanco area } \\
\text { Dumuyo (geothermal project): } \\
\text { La Bramadora } \\
\text { El Humazo } \\
\text { Los Tachos } \\
\text { Copahue (670 KW geothermal plant and resort) } \\
\text { Viticola (artesian wells) } \\
\text { Bahfa Blanca (artesian wells) } \\
\text { Argerich (artesian wells) } \\
\text { Colluco-Epulauquen }\end{array}$ & $\begin{array}{c}68^{\circ} \\
57^{\circ}, \max . \\
57^{\circ}, \max \\
68^{\circ} ? \\
40^{\circ}-90^{\circ} \\
76^{\circ} \\
46^{\circ}-90^{\circ} \\
62^{\circ}-90^{\circ} \\
52^{\circ}-80^{\circ} \\
55^{\circ}-64^{\circ} \\
48^{\circ}-90^{\circ} \\
54^{\circ}-58^{\circ} \\
50^{\circ} \\
92^{\circ} \\
98^{\circ} \\
94^{\circ} \\
93^{\circ}-138^{\circ}(\max . \\
\left.238^{\circ} \text { at } 930 \mathrm{~m}\right) \\
55^{\circ} \\
55^{\circ}-70^{\circ} \\
64^{\circ} \\
60^{\circ}\end{array}$ & $\begin{array}{l}\text { thermal and hot springs } \\
\text { thermal springs } \\
\text { thermal springs } \\
\text { hot water springs } \\
\text { hot springs } \\
\text { hot springs } \\
\text { hot springs } \\
\text { hot springs } \\
\text { hot springs } \\
\text { thermal springs } \\
\text { hot springs } \\
\text { thermal springs } \\
\text { thermal springs } \\
\text { hot springs and fumaroles } \\
\text { hot springs and fumaroles } \\
\text { hot springs and fumaroles } \\
\text { hot springs and fumaroles } \\
\text { thermal spring } \\
\text { hot springs } \\
\text { thermal spring } \\
\text { thermal springs }\end{array}$ \\
\hline $\begin{array}{l}\text { Bolivia } \\
\text { (Figure 23) }\end{array}$ & $\begin{array}{l}\text { Putina (Ulla-Ulla) } \\
\text { Charazani } \\
\text { Chuma } \\
\text { Matilde } \\
\text { Urmiri (resort) } \\
\text { Choquetanga } \\
\text { Kami-Ayopaya (resort) } \\
\text { Colcha (resort) } \\
\text { Pomarapa Volcano } \\
\text { Obrajes (resort) } \\
\text { Capachos (resort) }\end{array}$ & $\begin{array}{c}72^{\circ} \\
- \\
- \\
65^{\circ} \\
- \\
- \\
- \\
- \\
- \\
71^{\circ} \\
45^{\circ}\end{array}$ & $\begin{array}{l}\text { hot springs } \\
\text { hot springs } \\
\text { hot springs } \\
\text { thermal springs } \\
\text { thermal springs } \\
\text { thermal springs } \\
\text { thermal springs } \\
\text { thermal springs } \\
\text { strong hot springs } \\
\text { hot springs } \\
\text { thermal springs }\end{array}$ \\
\hline Bolivia & $\begin{array}{l}\text { Pazna-Urmiri (resort) } \\
\text { Challapata } \\
\text { Mulatos } \\
\text { Caiza (resort) } \\
\text { Caiti-Empexa (resort) } \\
\text { Pulacayo } \\
\text { Olca (Salar de la Laguna) }\end{array}$ & $\begin{array}{c}55^{\circ} \\
- \\
- \\
- \\
74^{\circ} \\
59^{\circ}-80^{\circ} \\
74^{\circ}\end{array}$ & $\begin{array}{l}\text { thermal springs } \\
\text { "NaCl" hot springs } \\
\text { low thermal } \mathrm{CO}_{2} \text { springs } \\
\text { strong sulphuric hot springs } \\
\text { hot springs } \\
\text { thermal and boiling springs } \\
\text { hot springs, fumaroles }\end{array}$ \\
\hline $\begin{array}{l}\text { Chile } \\
\text { (Figure 23) }\end{array}$ & 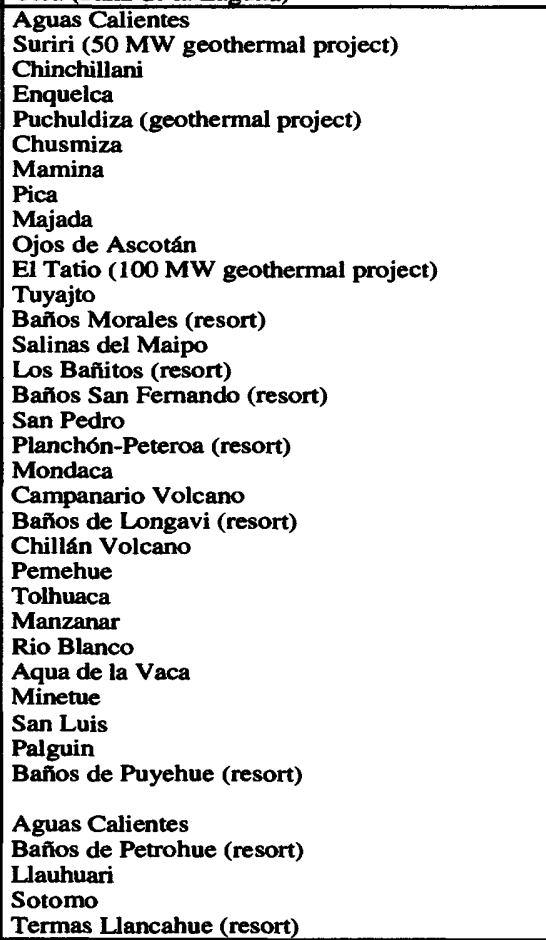 & $\begin{array}{l}86^{\circ} ? \\
60^{\circ}-80^{\circ} \\
86^{\circ} ? \\
86^{\circ} ? \\
180^{\circ}-250^{\circ} \\
\text { more than } 60^{\circ} \\
\text { more than } 60^{\circ} \\
\text { more than } 60^{\circ} \\
\text { more than } 60^{\circ} \\
\text { more than } 60^{\circ} \\
160^{\circ}-265^{\circ} \\
\text { more than } 60^{\circ} \\
68^{\circ} \\
\text { more than } 60^{\circ} \\
66^{\circ}-70^{\circ} \\
70^{\circ}-96^{\circ} \\
\text { more than } 60^{\circ} \\
60^{\circ} \\
\text { more than } 60^{\circ} \\
\text { more than } 60^{\circ} \\
66^{\circ}-71^{\circ} \\
\text { more than } 60^{\circ} \\
\text { more than } 60^{\circ} \\
90^{\circ} \\
\text { more than } 60^{\circ} \\
90^{\circ} \\
\text { more than } 60^{\circ} \\
\text { more than } 60^{\circ} \\
\text { more than } 60 \\
\text { more than } 60^{\circ} \\
55^{\circ}-70^{\circ} \\
50^{\circ}-75^{\circ} \\
60^{\circ} \\
\text { more than } 60^{\circ} \\
\text { more than } 60^{\circ} \\
58^{\circ} \\
\text { mo }\end{array}$ & $\begin{array}{l}\text { hot springs } \\
\text { hot springs } \\
\text { hot springs } \\
\text { hot springs } \\
\text { hot springs } \\
\text { hot spring } \\
\text { hot spring } \\
\text { hot spring } \\
\text { hot spring } \\
\text { hot spring } \\
\text { hot spring and fumaroles } \\
\text { hot spring } \\
\text { hot spring } \\
\text { hot spring } \\
\text { hot springs } \\
\text { hot springs, fumaroles } \\
\text { hot springs } \\
\text { multiple hot springs } \\
\text { hot springs } \\
\text { hot springs } \\
\text { thermal spring } \\
\text { thermal springs } \\
\text { hot springs } \\
\text { hot spring } \\
\text { thermal springs } \\
\text { hot springs } \\
\text { thermal springs } \\
\text { hot springs } \\
\text { hot springs } \\
\text { thermal springs } \\
\text { thermal, hot springs, and } \\
\text { fumaroles } \\
\text { hot springs } \\
\text { thermal springs } \\
\text { thermal springs } \\
\text { thermal springs } \\
\text { thermal spring } \\
\text { the }\end{array}$ \\
\hline $\begin{array}{l}\text { Colombia } \\
\text { (Figure 22) }\end{array}$ & $\begin{array}{l}\text { Ruiz Volcano (geothermal project) } \\
\text { Tolima Volcano } \\
\text { Santa Rosa Cabal } \\
\text { Caqueza } \\
\text { Puarace } \\
\text { Pasto Volcano (geothermal project) } \\
\text { Tuquerres Volcano (geothermal project) }\end{array}$ & $\begin{array}{c}50^{\circ}-90^{\circ} \\
\text { more than } 60^{\circ} \\
54^{\circ}-72^{\circ} \\
65^{\circ} \\
50^{\circ}-86^{\circ} \\
\max 102^{\circ} \\
70^{\circ}\end{array}$ & $\begin{array}{l}\text { thermal and hot springs } \\
\text { hot springs } \\
\text { thermal and hot springs } \\
\text { thermal springs } \\
\text { thermal and hot springs } \\
\text { hot spring, fumaroles } \\
\text { hot spring }\end{array}$ \\
\hline
\end{tabular}


Table 20. - continued Major geothermal sites by country, Southeast Quadrant, Circum-Pacific region (refer to figures 20 and 23)

\begin{tabular}{|c|c|c|c|}
\hline Country & Locality & $\begin{array}{l}\text { Temperature } \\
\left(\mathbf{C}^{\circ}\right)\end{array}$ & Type \\
\hline $\begin{array}{l}\text { Costa Rica } \\
\text { (Figure 22) }\end{array}$ & $\begin{array}{l}\text { Miravalles (50 MW geothermal project) } \\
\text { Peña Blanca } \\
\text { Agua Caliente de la Trinchera } \\
\text { Poas Volcano } \\
\text { Irazu Volcano } \\
\text { Ojo de Agua-Turrubures ( resort) } \\
\text { Paso Alumbre (resort) } \\
\text { San Cristobal (resort) } \\
\text { Jurquin River area }\end{array}$ & $\begin{array}{l}\text { more than } 60^{\circ} \\
\text { more than } 60^{\circ} \\
\text { "warm" } \\
58^{\circ}-100^{\circ} \\
- \\
\text { "warm" } \\
60^{\circ}-66^{\circ} \\
66^{\circ}-68^{\circ} \\
46^{\circ}-70^{\circ}\end{array}$ & $\begin{array}{l}\text { hot spring, solfatares } \\
\text { hot springs } \\
\text { thermal springs } \\
\text { hot springs and fumaroles } \\
\text { hot springs, solfatares, and } \\
\text { fumaroles } \\
\text { hot springs } \\
\text { thermal saline springs } \\
\text { thermal springs } \\
\text { thermal and hot springs }\end{array}$ \\
\hline \begin{tabular}{|l} 
Ecuador \\
(Figure 22)
\end{tabular} & $\begin{array}{l}\text { Tulfino } \\
\text { Guagua-Pichincha Volcano } \\
\text { Apuela } \\
\text { Agua Santa (resort) } \\
\text { Cicalpa } \\
\text { Pungola } \\
\text { Baños Cuenca (resort) } \\
\text { Portovelo } \\
\text { Aguas Calientes (resort) }\end{array}$ & $\begin{array}{l}50^{\circ} \\
50^{\circ} \\
52^{\circ} \\
54^{\circ} \\
- \\
50^{\circ} \\
87^{\circ} \\
- \\
-\end{array}$ & $\begin{array}{l}\text { thermal spring } \\
\text { thermal springs } \\
\text { thermal springs } \\
\text { thermal springs } \\
\text { thermal and hot springs } \\
\text { thermal spring } \\
\text { hot spring } \\
\text { thermal and hot springs } \\
\text { thermal and hot springs }\end{array}$ \\
\hline $\begin{array}{l}\text { El Salvador } \\
\text { (Figure 22) }\end{array}$ & $\begin{array}{l}\text { Hervidero El Obrajuelo } \\
\text { Ahuachapan Chipilapa (geothermal plant) } \\
\text { Hervidero Carolina } \\
\text { Chinameca (geothermal project) } \\
\text { Berlin (geothermal project) } \\
\text { San Vicente (geothermal project) } \\
\text { Santa Rosa de Lima (resort) } \\
\text { Jacotal } \\
\text { Olomega } \\
\text { Conchagua } \\
\end{array}$ & $\begin{array}{c}72^{\circ}-82^{\circ} \\
70^{\circ}-237^{\circ} \\
100^{\circ} \\
- \\
- \\
99^{\circ} \\
89^{\circ} \\
- \\
- \\
- \\
\end{array}$ & $\begin{array}{l}\text { hot springs } \\
\text { hot springs, fumaroles } \\
\text { hot spring, geyser, fumaroles } \\
\text { hot springs, fumaroles } \\
\text { hot springs, fumaroles } \\
\text { boiling springs, fumaroles } \\
\text { hot springs } \\
\text { hot springs } \\
\text { hot springs, fumaroles } \\
\text { hot springs } \\
\end{array}$ \\
\hline $\begin{array}{l}\text { Guatemala } \\
\text { (Figure 22) }\end{array}$ & $\begin{array}{l}\text { Zunil (15 MW geothermal plant) } \\
\text { Zunil, Fuentes Georginas (resort) } \\
\text { Atitlan Agua Caliente } \\
\text { La Canoa (resort) } \\
\text { Amatitlan (south shore) } \\
\text { Moyuta Volcano } \\
\end{array}$ & $\begin{array}{c}\max .287^{\circ} \\
55^{\circ}-65^{\circ} \\
47^{\circ}-50^{\circ} \\
- \\
60^{\circ}-98^{\circ} \\
150^{\circ} \\
\end{array}$ & $\begin{array}{l}\text { boiling water, hot springs } \\
\text { thermal springs } \\
\text { hot springs, fumaroles } \\
\text { hot springs } \\
\text { hot springs, fumaroles } \\
\text { boiling springs }\end{array}$ \\
\hline \begin{tabular}{|l|} 
Honduras \\
(Figure 22) \\
\end{tabular} & $\begin{array}{l}\text { Northern area } \\
\text { Choluteca area }\end{array}$ & - & $\begin{array}{l}\text { thermal and hot springs } \\
\text { several hot springs }\end{array}$ \\
\hline $\begin{array}{l}\text { Nicaragua } \\
\text { (Figure 22) }\end{array}$ & $\begin{array}{l}\text { Viejo Volcano } \\
\text { Chichigalpa Volcano } \\
\text { San Jacinto-Tizate } \\
\text { Momotombo ( } 35 \mathrm{MW} \text { geothermal plant) } \\
\text { Titipata } \\
\text { Omotepe Concepción } \\
\end{array}$ & $\begin{array}{c}91^{\circ} \\
- \\
- \\
\max .230^{\circ} \\
- \\
-\end{array}$ & $\begin{array}{l}\text { hot springs, fumaroles } \\
\text { fumaroles, and solfataras } \\
\text { boiling mud vents and springs } \\
\text { fumaroles, and solfataras } \\
\text { boiling springs, sulphur } \\
\text { deposits } \\
\text { fumaroles, and solfataras } \\
\end{array}$ \\
\hline $\begin{array}{l}\text { Panama } \\
\text { (Figure 22) }\end{array}$ & $\begin{array}{l}\text { Chiriqui Volcano } \\
\text { Pando } \\
\text { Agua Salud (resort) } \\
\text { Coibajo } \\
\end{array}$ & $\begin{array}{c}72^{\circ} \\
42^{\circ}-72^{\circ} \\
52^{\circ}\end{array}$ & $\begin{array}{l}\text { fumaroles and hot springs } \\
\text { hot springs } \\
\text { several thermal springs } \\
\text { thermal spring }\end{array}$ \\
\hline $\begin{array}{l}\text { Peru } \\
\text { (Figure 22) }\end{array}$ & $\begin{array}{l}\text { Quillate } \\
\text { Cajamarca (lnca bathing resort) } \\
\text { Chuquillanqui } \\
\text { Huaranchai (Pampa spring) } \\
\text { Cachicadán } \\
\text { Tablachaca }\end{array}$ & $\begin{array}{c}\text { more than } 50^{\circ} \\
- \\
\text { more than } 50^{\circ} \\
75^{\circ} \\
71^{\circ} \\
53^{\circ}\end{array}$ & $\begin{array}{l}\text { hot springs } \\
\text { hot springs, fumaroles } \\
\text { thermal springs } \\
\text { hot springs } \\
\text { hot springs } \\
\text { thermal and hot springs }\end{array}$ \\
\hline Peru & $\begin{array}{l}\text { Minabamba } \\
\text { Pomabamba } \\
\text { Mancos } \\
\text { Chancos } \\
\text { Tauripampa } \\
\text { Baños } \\
\text { Andajes-Churin (resort) } \\
\text { Rio Perené } \\
\text { San José de Baños (resort) } \\
\text { Tingo de Huacho } \\
\text { Baños del Sr. Cura (resort) } \\
\text { Colpani } \\
\text { Marcapata } \\
\text { Ollaechea } \\
\text { Quilcata } \\
\text { Puquío (resort) } \\
\text { Quisicollo } \\
\text { Huayana-Putina } \\
\text { Carumas Geyser Valley } \\
\text { Ulican-Sancos } \\
\text { Calacoa } \\
\text { Ticaco } \\
\text { Caliente (resort) } \\
\end{array}$ & $\begin{array}{l}60^{\circ}-80^{\circ} \\
\text { more than } 50^{\circ} \\
50^{\circ} \\
70^{\circ}-75^{\circ} \\
\text { more than } 50^{\circ} \\
56^{\circ}-61^{\circ} \\
50^{\circ}-55^{\circ} \\
- \\
- \\
58^{\circ} \\
\text { more than } 50^{\circ} \\
59^{\circ} \\
60^{\circ}-70^{\circ} \\
66^{\circ}-69^{\circ} \\
\text { more than } 50^{\circ} \\
\text { more than } 50^{\circ} \\
55^{\circ}-62^{\circ} \\
80^{\circ} \\
- \\
\text { more than } 50^{\circ} \\
\text { more than } 180^{\circ} \\
69^{\circ} \\
-\end{array}$ & $\begin{array}{l}\text { hot springs } \\
\text { thermal springs } \\
\text { thermal springs } \\
\text { hot springs } \\
\text { thermal springs } \\
\text { hot springs } \\
\text { hot springs } \\
\text { hot springs } \\
\text { thermal springs } \\
\text { thermal springs } \\
\text { thermal springs } \\
\text { thermal springs } \\
\text { hot springs } \\
\text { thermal springs } \\
\text { thermal springs } \\
\text { thermal springs } \\
\text { hot springs } \\
\text { geysers, boiling springs, fumaroles } \\
\text { thermal springs } \\
\text { hot water reservoir } \\
\text { hot water } \\
\text { "boiling" springs, fumaroles }\end{array}$ \\
\hline $\begin{array}{l}\text { Venezuela } \\
\text { (Figure 22) }\end{array}$ & $\begin{array}{l}\text { Pilar-Casanay area (geothermal project) } \\
\text { Golfo Cariaco area } \\
\text { Carupano area (resort) } \\
\text { Barcelona-Cumana (geothermal project) } \\
\text { Las Trincheras } \\
\text { Termales Mérida (resort) } \\
\text { Ureña }\end{array}$ & $\begin{array}{c}- \\
- \\
- \\
- \\
90^{\circ}-97^{\circ} \\
- \\
-\end{array}$ & $\begin{array}{l}\text { hot springs } \\
\text { thermal springs } \\
\text { hot springs, solfataras } \\
\text { hot springs } \\
\text { hot springs } \\
\text { thermal springs } \\
\text { thermal springs }\end{array}$ \\
\hline
\end{tabular}




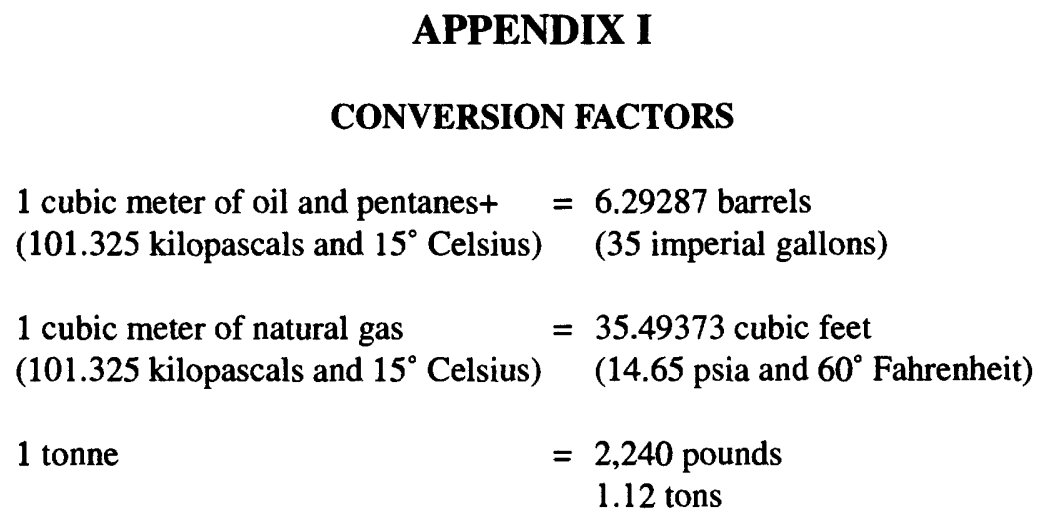

\section{APPENDIX II}

\section{LIST OF ABBREVIATIONS USED}

$\begin{array}{ll}\text { ASTM } & \text { American Society for Testing and Materials } \\ \text { API } & \text { American Petroleum Institute } \\ \text { B } & \text { billion }\left(10^{9}\right) \\ \text { bbl } & \text { barrel } \\ \text { BCF } & \text { billion cubic feet } \\ \text { b/d } & \text { barrels/day } \\ \text { cf } & \text { cubic feet } \\ \text { cf/d } & \text { cubic feet/day } \\ \text { EUR } & \text { estimated ultimate recovery } \\ \text { M } & \text { thousand }\left(10^{3}\right) \\ \text { MCF } & \text { thousand cubic feet } \\ \text { MM } & \text { million }\left(10^{6}\right) \\ \text { MMB } & \text { million barrels } \\ \text { T } & \text { trillion }\left(10^{12}\right) \\ \text { TCF } & \text { trillion cubic feet }\end{array}$




\section{APPENDIX III}

\section{GLOSSARY}

Crude oil-A mixture of hydrocarbons that is recovered in a liquid phase at atmospheric conditions of pressure and temperature through a wellbore from a naturally occurring underground reservoir. Crude oil may include small amounts of non-hydrocarbons produced with the liquids.

Acceptable ranges for further classification of crude oil by density suggested by a study group of the World Petroleum Congress (Martinez and others, 1984) are as follows:

Heavy, $10-22.3^{\circ}$ API gravity $(1000-920 \mathrm{~kg} / \mathrm{m} 3)$

Medium, $22.3-31.1^{\circ}$ API gravity $(920-870 \mathrm{~kg} / \mathrm{m} 3)$

Light, greater than $31.1^{\circ}$ API gravity (less than $870 \mathrm{~kg} / \mathrm{m} 3$ )

To be added to this are definitions of Meyer and others (1985):

Extra heavy, less than $10^{\circ}$ API gravity (greater than $1000 \mathrm{~kg} / \mathrm{m} 3$ ) but mobile in the reservoir, hence, producible through a wellbore.

Bitumen, less than $10^{\circ} \mathrm{API}$ gravity (greater than $100 \mathrm{~kg} / \mathrm{m} 3$ ) and immobile in the reservoir.

Estimated Ultimate Recovery (EUR)-An estimate of the total reserves which will ultimately be produced from a field or field complex. The EUR includes cumulative production and remaining established reserves, and may include an estimate of possible future additions through extensions and new pool tests.

Field-An area consisting of a single reservoir or multiple reservoirs all related to the same geologic, structural, or stratigraphic feature.

Field Complex-An area which encompasses two or more fields that are in close proximity which share a common geologic mode of occurrence. Examples are fault-separated fields such as the A. J. Bermuda Complex of Mexico and the pinnacle reefs of Rainbow, Canada.

Gravity, API-A standard adopted by the American Petroleum Institute to express the specific gravity of oil. The lower the specific gravity, the higher the API gravity. API gravity = $\left(141.5 /\right.$ specific gravity at $\left.60^{\circ} \mathrm{F}\right) 131.5$.

Hydrocarbon-Chemical compounds consisting wholly of hydrogen and carbon.

Initial Established Reserves-An estimate of the original total reserves prior to any production which are deemed to be recoverable with current technology and under present economic conditions, proved by drilling, testing, or production plus recoverable reserves interpreted to exist with reasonable certainty.

Remaining Established Reserves-Initial established reserves less cumulative production.

Natural Gas-A mixture of hydrocarbon compounds and small quantities of various non-hydrocarbons that exist in the gaseous phase or in solution with crude oil in natural underground reservoirs and which is gaseous at atmospheric conditions of pressure and temperatures. Natural gas is generally classified into two categories based on the type of occurrence in the reservoir.

Non-associated Gas-Free natural gas not in contact with crude oil in the reservoirs.

Associated Gas-Generally includes both associated and dissolved gas. Associated gas is free natural gas, commonly known as gas cap gas, which overlies and is in contact with crude oil. Dissolved gas is natural gas which is in solution with crude oil at reservoir conditions.

Raw Gas-Natural gas as it is produced from the reservoir that includes varying amounts of the heavier hydrocarbons which liquefy at atmospheric conditions, water vapor, sulphur compounds, such as hydrogen sulfide, and other non-hydrocarbon gases, such as carbon dioxide, nitrogen, or helium.

Marketable Gas-Natural gas which is available to a transmission line after removal of certain hydrocarbons and non-hydrocarbon compounds present in the raw natural gas and which meets specifications for use as a domestic, commercial, or industrial fuel. Marketable natural gas excludes field and plant fuel and losses, excepting those related to downstream reprocessing plants.

Natural Gas Liquids-Those hydrocarbons in the reservoir which are separated from the natural gas as liquids either in the reservoir through the process of retrograde condensation or at the surface through the process of condensation, absorption, or adsorption or other methods in field separators, and gas plants. Generally such liquids consist of propane and heavier hydrocarbons and are commonly referred to as condensate and liquified petroleum gases. Where hydrocarbon components lighter than propane are recovered as liquids these components are also included in the natural gas liquids.

Oil Sand-Sand and other rock material impregnated with crude oil that is classified as bitumen. The gravity is generally in the range of $10^{\circ} \mathrm{API}$ and less (greater than $1000 \mathrm{~kg} / \mathrm{m} 3$ ), immobile in the reservoir, and generally not recoverable by conventional wellbore methods. Often referred to as tar sands.

Oil Shale-Shale that contains an oil-yielding material called kerogen.

Pentanes Plus-A mixture mainly of pentanes and heavier hydrocarbons which ordinarily may contain some butanes and which is obtained from the processing of raw gas, condensate, or crude oil.

Synthetic Oil-A mixture of hydrocarbons, which is derived by upgrading bitumen in oil sands or kerogen in oil shales. 


\section{APPENDIX IV}

Summarized A.S.T.M. "Classification of coals by rank

\begin{tabular}{|c|c|c|c|c|c|c|}
\hline \multirow[t]{2}{*}{ Class Group } & \multicolumn{2}{|c|}{$\begin{array}{c}\text { Fixed Carbon* } \\
\text { (Percent) }\end{array}$} & \multicolumn{2}{|c|}{$\begin{array}{c}\text { Volatile Matter* } \\
\text { (Percent) }\end{array}$} & \multicolumn{2}{|c|}{$\begin{array}{c}\text { Calorific Value* } \\
\text { (Btu) }\end{array}$} \\
\hline & $\begin{array}{l}\text { Equal or } \\
\text { Greater } \\
\text { Than }\end{array}$ & $\begin{array}{l}\text { Less } \\
\text { Than }\end{array}$ & $\begin{array}{c}\text { Greater } \\
\text { Than }\end{array}$ & $\begin{array}{l}\text { Equal or } \\
\text { Less } \\
\text { Than }\end{array}$ & $\begin{array}{l}\text { Equal or } \\
\text { Greater } \\
\text { Than }\end{array}$ & $\begin{array}{l}\text { Less } \\
\text { Than }\end{array}$ \\
\hline Anthracitic & 86 & & & 14 & & \\
\hline $\begin{array}{l}\text { Bituminous } \\
\text { Low volatile } \\
\text { bituminous }\end{array}$ & 78 & 86 & 14 & 22 & & \\
\hline $\begin{array}{c}\text { Medium volat } \\
\text { bituminous }\end{array}$ & 69 & 78 & 22 & 31 & & \\
\hline $\begin{array}{c}\text { High volatile } \\
\text { bituminous }\end{array}$ & & 69 & 31 & & 10,500 & 14,000 \\
\hline Subbituminous & & & & & 8,300 & 11,500 \\
\hline Lignitic & & & & & 6,300 & 8,300 \\
\hline
\end{tabular}

* Dry, Mineral - Matter Free Basis (Latour and Chrismas, 1970) 
